VIVIANE LIMA DE MORAIS

ESTUDO COMPARATIVO DA DEFORMAÇÃO A FRIO E DA RESISTÊNCIA À CORROSÃO NOS AÇOS INOXIDÁVEIS AUSTENÍTICOS AISI 201 E AISI 304 
VIVIANE LIMA DE MORAIS

ESTUDO COMPARATIVO DA DEFORMAÇÃO A FRIO E DA RESISTÊNCIA À CORROSÃO NOS AÇOS INOXIDÁVEIS AUSTENÍTICOS AISI 201 E AISI 304

Dissertação apresentada à Escola Politécnica da Universidade de São Paulo para obtenção do título de Mestre em Engenharia 
VIVIANE LIMA DE MORAIS

\title{
ESTUDO COMPARATIVO DA DEFORMAÇÃO A FRIO E DA RESISTÊNCIA À CORROSÃO NOS AÇOS INOXIDÁVEIS AUSTENÍTICOS AISI 201 E AISI 304
}

\author{
Dissertação apresentada à Escola \\ Politécnica da Universidade de São \\ Paulo para obtenção do título de Mestre \\ em Engenharia \\ Área de Concentração: \\ Engenharia Metalúrgica e de Materiais \\ Orientador: \\ Prof. Dr. Angelo Fernando Padilha
}


Este exemplar foi revisado e alterado em relação à versão original, sob responsabilidade única do autor e com a anuência de seu orientador.

São Paulo, 22 de julho de 2010.

Assinatura do autor

Assinatura do orientador

FICHA CATALOGRÁFICA

Morais, Viviane Lima de

Estudo comparativo da deformação a frio e da resistência à Corrosão nos aços inoxidáveis austeníticos AISI 201 e AISI 304 /

V.L. de Morais. --São Paulo, 2010.

$144 \mathrm{p}$.

Dissertação (Mestrado) - Escola Politécnica da Universidade de São Paulo. Departamento de Engenharia Metalúrgica e de Materiais.

1.Aço inoxidável austenítico 2.Transformação de fase 3.ReSistência à corrosão I.Universidade de São Paulo. Escola Politécnica. Departamento de Engenharia Metalúrgica e de Materiais II.t. 


\section{DEDICATÓRIA}

Este trabalho é dedicado aos meus pais,

Pedro e Lourdes. 


\section{AGRADECIMENTOS}

Ao Prof. Dr. Angelo Fernando Padilha pela irrestrita colaboração e valiosa orientação;

A MAHLE Metal Leve pela permissão da realização deste trabalho e pelo fornecimento do material e equipamentos;

Ao meu marido Ailton pela paciência e apoio incondicional durante toda a elaboração desse trabalho;

Aos meus pais por servirem de exemplo que posso ir muito mais além;

À Dra. Maysa Terada pela imensa contribuição técnica; pela ajuda na obtenção e análise dos resultados de corrosão;

Ao IPEN pela permissão da realização dos ensaios de corrosão;

À Renata Cristina de Soler pela gentileza e grande ajuda na busca de artigos técnicos;

Ao amigo Eduardo Kakitsuka pela constante disponibilidade em ajudar e pelo auxílio dos testes de laminação.

Ao técnico Danilo do PMT pela disposição do uso do forno para a realização do tratamento térmico de solubilização;

Aos colegas do laboratório de microscopia Nilson Luvizutto, Donizete Souza e Silas Aragão pela eficácia e ajuda constante;

Ao Antônio Carlos Joaquim pela obtenção das análises de difração de raios $\mathrm{X}$ e pela grande contribuição técnica;

À Clélia Meguerditchian pela ajuda na revisão das referências bibliográficas;

Ao Prof. Dr. Ronald Lesley Plaut pelo auxílio na revisão do resumo/ abstract;

$\mathrm{E}$ a todos que ajudaram direta ou indiretamente na realização deste trabalho; 


\section{EPÍGRAFE}

To accomplish great things, we must not only dream but also act, not only plan but also believe.

Anatole France 


\section{ESTUDO COMPARATIVO DA DEFORMAÇÃO A FRIO E DA RESISTÊNCIA À CORROSÃO NOS AÇOS INOXIDÁVEIS AUSTENÍTICOS AISI 201 E AISI 304}

\section{RESUMO}

A crescente demanda de aplicações de aços inoxidáveis austeníticos e a constante pressão para redução de custo nas empresas siderúrgicas, devido à alta volatilidade no custo do níquel, resultaram em novos desenvolvimentos de aços da série 200 . Esta nova classe de aços inoxidáveis austeníticos contém elevados teores de manganês e nitrogênio em substituição ao elemento níquel. A justificativa para a realização deste trabalho é a escassez de estudos comparativos entre aços inoxidáveis austeníticos da série 200 e série 300 disponíveis na literatura em relação ao comportamento da transformação de fase induzida pela deformação e da resistência à corrosão. Os principais fatores que afetam a microestrutura no endurecimento por deformação são: a energia de defeito de empilhamento, composição química, temperatura, grau, taxa e modo de deformação. Realizou-se uma análise crítica e adequação dos conceitos de níquel e cromo equivalente para os aços AISI 201 e AISI 304. Amostras desses aços foram solubilizadas, laminadas e tracionadas em diferentes condições para caracterização microestrutural com o auxílio de técnicas de microscopia óptica, microscopia eletrônica de varredura, difração de raios $X$, ferritoscópio e microdureza. Curvas de endurecimento em função do grau de deformação, fração volumétrica de martensita em função do grau de deformação, assim como a evolução microestrutural e sua respectiva identificação de fase com o grau de deformação foram resultados obtidos deste trabalho. Em geral, aumentando a deformação plástica a frio, maior é a dureza para ambos os aços e maior é a fração volumétrica de martensita induzida por deformação. O aço AISI 201 é mais susceptível a transformação de fase do que o aço AISI 304 devido a sua menor EDE. Ensaios eletroquímicos de espectroscopia de impedância eletroquímica e polarização potenciodinâmica anódica foram realizados para avaliação da resistência a corrosão e para avaliar o comportamento da repassivação. Ambos os aços apresentaram comportamento similares quanto à resistência à corrosão, além de apresentarem potenciais de corrosão da ordem de 
$10^{-8} \mathrm{~A} / \mathrm{cm}^{2}$, típico de materiais passivos.

Palavras-chave: Aços inoxidáveis austeníticos. AISI 201. AISI 304. Transformação de fase induzida por deformação. Resistência à corrosão. 
COMPARATIVE STUDY OF THE COLD DEFORMATION AND CORROSION RESISTANCE OF AISI 201 AND AISI 304 AUSTENITIC STAINLESS STEELS

\begin{abstract}
The continuous increase in the application demand of austenitic stainless steels and the constant pressure for cost reduction in the steelmaking industry, due to the high instability of nickel price, has conduced to new developments of the AISI 200 series steels. This new austenitic stainless steel series employes high manganese and nitrogen contents in substitution to nickel. The reason of this work is the lack of comparative studies in the literature between austenitic stainless steels of 200 and 300 series relative to the martensite strain induced phase transformation and its corrosion resistance. The main factors that affect microstructure on strain-hardening are: stacking fault energy, chemical composition, temperature, strain and strain rate. A critical analysis of the concept related to the nickel and chrome equivalents for the AISI 201 and AISI 304 steels has been carried out. Samples of these steels were heat treated and cold rolled to different strains for subsequent microstructural evaluation using equipments such as optical microscope, scanning electron microscope, X-ray diffraction, microhardness and ferritoscope. Strain hardening versus strain, martensite volume fraction versus strain, as well as microstructure evolution and its respective phase identification with strain are some of the main results obtained in this study. In general, increasing the strain hardening, the higher will be the hardness of both stainless steels and higher is the induced martensite volume fraction. The AISI 201 steel presented higher susceptibility to induced phase transformation in comparison to the AISI 304 steel due to its lower stacking fault energy. Electrochemical impedance spectroscopy and anodic potenciodynamic polarization were the techniques used in this work to evaluate the corrosion resistance and passivation behavior respectively. Both steels presented similar corrosion resistance, apart from presenting a corrosion potential of about $10^{-8} \mathrm{~A} / \mathrm{cm}^{2}$, which is typical for passivated materials.
\end{abstract}


Keywords: Austenitic stainless steel. AISI 201. AISI 304. Strain hardening. Strain induced martensite transformation. Corrosion resistance. 


\section{LISTA DE ILUSTRAÇÕES}

Figura 01 - Diagrama de Schaeffler

Figura 02 - Visão tridimensional do diagrama Fe-Cr-Ni 07

Figura 03 - Secções isotérmicas do diagrama de fases ternário $\mathrm{Fe}-\mathrm{Cr}-\mathrm{Ni} \quad 08$

Figura 04 - Equilíbrio do teor de níquel e cromo nas séries 200 e 300 dos AIAs $\quad 10$

Figura 05 - Teores de níquel e manganês em aços inoxidáveis

Figura 06 - Variação do custo do $\mathrm{Mn}, \mathrm{Ni}$ e $\mathrm{Cr}$ nos últimos cinco anos desde abril de 2005

Figura 07 - Produção mundial de Al

Figura 08 - Defeito de empilhamento na estrutura CFC 19

Figura 09 - Discordâncias parciais delimitando defeitos de empilhamento

Figura 10 - Correlação entre martensita induzida por deformação e EDE

Figura 11 - Tipos de diagramas de equilíbrio para o sistema ferro-elementos de liga

Figura 12 - Tendência relativa dos elementos de liga para formação de ferrita e para formação de austenita

Figura 13 - Efeito do endurecimento por solução sólida na austenita

Figura 14 - Variação do limite de escoamento com o teor de carbono e nitrogênio 27

Figura 15 - Efeito do nitrogênio na resistência mecânica dos AIAs

Figura 16 - Fração volumétrica das fases presentes em função da temperatura 29

Figura 17 - Curva tensão versus deformação de um AIA realizado em diferentes temperatura

Figura 18 - Evolução da transformação martensítica induzida por deformação do aço AISI 304 para uma deformação de $10^{-3} / \mathrm{s}$ em função da temperatura

Figura 19 - Curva experimental tensão-deformação à temperatura de $-60^{\circ} \mathrm{C}$ e taxa de deformação de $10^{-4} \mathrm{~s}^{-1}$ do aço AISI 304

Figura 20 - Efeito da temperatura na formação da martensita em aço AISI 304 para as deformações verdadeiras

Figura 21 - Curva comparativa do comportamento dos aços AISI 201 modificado e AISI 304

Figura 22 - Efeito do teor de níquel na curva tensão-deformação para AIAs com 17\% 
de cromo

Figura 23 - Difração de raios $X$ de tiras do aço AISI 304L laminadas a frio a $0{ }^{\circ} \mathrm{C} \quad 36$ Figura 24 - Curva tensão-deformação de um AIA 18\%Cr-12\%Ni-2\%Mo deformado em diferentes taxas de deformação à temperatura de $20^{\circ} \mathrm{C}$

Figura 25 - Variação das quantidades de martensita $\alpha^{\prime}$ e $\varepsilon$ com o grau de deformação para os aços AISI 304 e AISI 316

Figura 26 - Curva típica tensão-deformação dos aços inoxidáveis austeníticos AISI 301 e AISI 304

Figura 27 - Efeito da deformação nas propriedades magnéticas e dureza do aço AISI 304

Figura 28 - Ferritoscópio Fisher modelo MP30E

Figura 29 - Saturação magnética em função da deformação verdadeira de um aço AISI 201 modificado

Figura 30 - Curva de DSC para um aço AISI 304 com deformação verdadeira de 0,05 a 0,35 realizada na temperatura de $-10^{\circ} \mathrm{C}$

Figura 31 - Curva tensão versus deformação obtida por simulação e experimental 49 Figura 32 - Efeito da temperatura na reversão da martensita $\alpha$ ' e consequente efeito na magnetização, microdureza e fração volumétrica de martensita

Figura 33 - Desenho esquemático do conjunto pistão-anel-pino-biela-camisa $\quad 54$

Figura 34 - Desenho esquemático representativo do anel de óleo de três peças 55 Figura 35 - Processamento de fabricação do espaçador (a) estágio de conformação; (b) detalhe das engrenagens

Figura 36 - Espaçador (a) região de identificação do corte transversal A; (b) visualização do embutimento com 50x de ampliação e ataque Marble; (c) detalhe da microestrutura, ataque ácido oxálico e 100x de ampliação

Figura 37 - Espaçador (a) região de identificação do corte transversal; (b) visualização do embutimento com 50x de ampliação e ataque Marble; (c) detalhe da microestrutura, ataque ácido oxálico e 100x de ampliação

Figura 38 - Espaçador (a) região de identificação do corte transversal A; (b) visualização do embutimento com 50x de ampliação e ataque Marble; (c) detalhe da microestrutura, ataque ácido oxálico e 100x de ampliação

Figura 39 - Desenho esquemático da célula utilizada nos ensaios eletroquímicos 60

Figura 40 - Desenho esquemático da célula utilizada nos ensaios eletroquímicos 68

Figura 41 - Diagrama de Schaeffler modificado com as previsões de microestrutura 
para os aços AISI 201 e AISI 304

Figura 42 - Microestruturas dos aços na condição "como recebida" (a) AISI 201 e (b) AISI 304. Ataque de ácido oxálico. MO 73

Figura 43 - Difratogramas dos aços AISI 201 e AISI 304. Radiação CuK $\alpha$ 76

Figura 44 - Correlação entre martensita induzida por deformação e a EDE 79 Figura 45 - Diagramas de espectroscopia de impedância eletroquímica dos aços inoxidáveis AISI 201 e AISI 304: a) Bode ou módulo de impedância Z, b) ângulo de fase - após 24 horas de imersão em solução PBS a $25^{\circ} \mathrm{C}$ e c) Nyquist.

Figura 46 - Diagramas de polarização potenciodinâmica dos aços inoxidáveis AISI 201 e AISI 304 após $24 \mathrm{~h}$ de imersão em solução PBS a $25{ }^{\circ} \mathrm{C}$ 84

Figura 47 - Micrografias do aço inoxidável AISI 201 após polarização potenciodinâmica. Corrosão localizada. MEV. Imagem de elétrons secundários. (a) $500 x$ de ampliação e (b) 5.000x de ampliação.

Figura 48 - Micrografia do aço inoxidável AISI 304 após polarização potenciodinâmica. Corrosão por pite. MEV. Imagem de elétrons secundários. 500x de ampliação.

Figura 49 - Microestruturas dos aços na condição solubilizada. (a) AISI 201 e (b) AISI 304. Ataque de ácido oxálico. MO.

Figura 50 - Análise de energia dispersiva (EDS) da matriz dos aços solubilizados (a) AISI 201 e (b) AISI 304

Figura 51- Difratogramas dos aços solubilizados (a) AISI 201 e (b) AISI 304. Radiação CuKo.

Figura 52 - Microestruturas dos aços após resfriamento em nitrogênio líquido a -196 ${ }^{\circ} \mathrm{C}$. (a) AISI 201 e (b) AISI 304. Ataque de ácido oxálico eletrolítico. MO 93 Figura 53 - Microestruturas representativas do aço AISI 201 laminado em diferentes graus de redução: (a) $5 \%$, (b) $10 \%$, (c) $15 \%$, (d) $20 \%$, (e) $25 \%$, (f) $30 \%$. Ataque em ácido oxálico eletrolítico. MO. Ampliação de 500x

Figura 54 - Microestruturas representativas do aço AISI 304 laminado em diferentes graus de redução: (a) $5 \%$, (b) $10 \%$, (c) $15 \%$, (d) $20 \%$, (e) $25 \%$, (f) $30 \%$. Ataque em ácido oxálico eletrolítico. MO. Ampliação de 500x 97

Figura 55 - Tiras de aço laminado com 5\% de deformação. MEV. (a) AISI 201 e (b) AISI 304. Imagem de elétrons secundários

Figura 56 - Variação da dureza em função do grau de deformação durante a 
laminação

Figura 57 - Variação da porcentagem de fase magnética em função do grau de deformação durante laminação

Figura 58 - Difratogramas representativos dos aços AISI 201 laminado em diferentes graus de redução: (a) $5 \%$, (b) $10 \%$, (c) $15 \%$, (d) $20 \%$, (e) $25 \%$, (f) $30 \%$. Radiação CuKo.

Figura 59 - Difratogramas representativos dos aços AISI 304 laminado em diferentes graus de redução: (a) $5 \%$, (b) $10 \%$, (c) $15 \%$, (d) $20 \%$, (e) $25 \%$, (f) $30 \%$. Radiação CuKo.

Figura 60 - Fração volumétrica de fases nos aços laminados (a) AISI 201 e (b) AISI 304 108

Figura 61 - Curva tensão versus deformação (de engenharia) dos aços AISI 201 e AISI 304.

Figura 62 - Microestruturas representativas do aço AISI 201 tracionado a uma velocidade de $10 \mathrm{~mm} / \mathrm{min}$ em diferentes graus de redução: (a) $5 \%$, (b) $10 \%$, (c) $15 \%$, (d) $20 \%$, (e) $25 \%$, (f) $30 \%$. Ataque em ácido oxálico eletrolítico. MO. Ampliação de $500 x$.

Figura 63 - Microestruturas representativas do aço AISI 304 tracionado a uma velocidade de $10 \mathrm{~mm} / \mathrm{min}$ em diferentes graus de redução: (a) $5 \%$, (b) $10 \%$, (c) $15 \%$, (d) $20 \%$, (e) $25 \%$, (f) $30 \%$. Ataque em ácido oxálico eletrolítico. MO. Ampliação de $500 x$.

Figura 64 - Dureza das tiras tracionadas.

Figura 65 - Fração volumétrica de fases nos aços tracionados (a) AISI 201 e (b) AISI 304

Figura 66 - Curva tensão $x$ deformação (de engenharia) em função da taxa da deformação (a) AISI 201 e (b) AISI 304.

Figura 67 - Dureza dos aços AISI 201 e AISI 304 laminados e tracionados em função do grau de deformação

Figura 68 - Curva experimental da reversão da martensita para os aços AISI 201 e AISI 304 a partir de amostras laminadas em $30 \%$ de redução 


\section{LISTA DE TABELAS}

Tabela 1 - Produção de aço inoxidável e resistente ao calor (métrica em $10^{3}$ toneladas)

Tabela 2 - Composição química (\% em massa) dos AIAs classificados pela AISI 09 Tabela 3 - Especificação de diferentes AIAs da série 200 não especificados por classificação internacional $\quad 13$

Tabela 4 - Temperatura de transformação martensítica para alguns aços AlAs $\quad 17$

Tabela 5 - EDE de metais e ligas de estrutura CFC 21

Tabela 6 - Faixas de trabalho da taxa de deformação 37

Tabela 7 - Principais características dos dois tipos de martensita induzida por deformação 42

Tabela 8 - Composição química dos aços inoxidáveis austeníticos (\% em massa) 62

Tabela 9 - Composição química do meio PBS 68

Tabela 10 - Composição química (\% em massa) dos aços pesquisados $\quad 71$

Tabela 11 - Microdureza dos aços na condição "como recebida"

Tabela 12 - Medidas magnéticas dos aços na condição "como recebida" 75

Tabela 13 - Tamanho de grão dos aços na condição "como recebida".

Tabela 14 - Cálculo das temperaturas $\mathrm{M}_{\mathrm{s}} / \mathrm{M}_{\mathrm{d} 30 / 50}$ e da EDE 77

$\begin{array}{ll}\text { Tabela 15 - Resistência equivalente por pite (PRE) dos AIAs. } & 87\end{array}$

Tabela 16 - Análise do tamanho de grão dos aços solubilizados $\quad 89$

Tabela 17 - Microdureza dos aços solubilizados. $\quad 90$

Tabela 18-Medidas magnéticas dos aços solubilizados $\quad 91$

Tabela 19 - Microdureza dos aços solubilizados após resfriamento sub-zero. $\quad 94$

Tabela 20 - Medidas magnéticas dos aços solubilizados após resfriamento sub-zero

Tabela 21 - Espessura das tiras dos aços AISI 201 e AISI 304 após laminação 95 Tabela 22 - Dureza $\left(\mathrm{HV}_{0,1}\right)$ em função do grau de deformação para os aços AISI 201 e AISI 304

Tabela 23 - Medidas magnética em função do grau de deformação para os aços AISI 201 e AISI 304 
Tabela 24 - Propriedades mecânicas do aço AISI 201

Tabela 25 - Propriedades mecânicas do aço AISI 304

Tabela 26 - Dureza $\left(\mathrm{HV}_{0,1}\right)$ em função do grau de deformação do ensaio de tração para os aços AISI 201 e AISI 304

Tabela 27 - Medidas magnéticas em função do grau de deformação do ensaio de tração para os aços AISI 201 e AISI 304 
Al Aço inoxidável

AIA Aço inoxidável austenítico

AISI American iron and steel institute

ASTM American society for testing and materials

CCC Cúbico de corpo centrado

CFC Cúbico de face centrada

CESIMIT Energia crítica necessária para que ocorra a transformação da austenita para martensita induzida por deformação

$\mathrm{Cr}_{\text {eq }} \quad$ Cromo equivalente

DRX Difração de raios $X$

DSC Calorimetria exploratória diferencial

E Módulo de elasticidade

EDE Energia de defeito de empilhamento

EIE Espectroscopia de impedância eletroquímica

EDS Espectroscopia por dispersão de energia

HC Hexagonal compacta

HPT Ensaio de torção a alta pressão

HV Dureza Vickers

ICP Espectrometria de emissão óptica com acoplamento induzido de plasma

ISO International organization for standardization

ISSF International stainless steel forum

LE Limite de escoamento (MPa)

LR Limite de resistência (MPa)

$M_{d} \quad$ Temperatura abaixo da qual a tensão por deformação induz a transformação martensítica

Ms A temperatura a partir da qual a austenita transforma-se espontaneamente em martensita devido ao resfriamento

MEM Minimum essential medium

MET Microscopia eletrônica de transmissão 
MEV Microscopia eletrônica de varredura

MO Microscopia óptica

$\mathrm{Ni}_{\text {eq }} \quad$ Níquel equivalente

PBS Phosphate buffered saline solution (solução salina tamponada com fosfato)

PRE Pitting resistance equivalent (Resistência equivalente por pite)

TG Tamanho de grão 


\section{LISTA DE SÍMBOLOS}

$\begin{array}{ll}\gamma & \text { Fase austenita - estrutura CFC } \\ \alpha & \text { Fase ferrita - estrutura CCC } \\ \sigma & \text { Fase sigma } \\ \delta & \text { Ferrita delta } \\ \alpha^{\prime} & \text { Fase martensita induzida por deformação - estrutura CCC } \\ \varepsilon & \text { Fase martensita induzida por deformação - estrutura HC } \\ { }^{\circ} \mathrm{C} & \text { graus Celsius }\end{array}$




\section{SUMÁRIO}

INTRODUÇÃO

OBJETIVO

1 REVISÃO DA LITERATURA

$\begin{array}{lll}1.1 & \text { Aços inoxidáveis } & 04\end{array}$

$\begin{array}{lll}1.2 & \text { Aços inoxidáveis austeníticos } & 07\end{array}$

1.3 Formação da martensita 16

1.4 Endurecimento por deformação a frio 18

1.4.1 Fatores que afetam a microestrutura do metal 18

1.4.1.1 Efeito da energia de defeito de empilhamento 18

1.4.1.2 Efeito da composição química 23

1.4.1.3 Efeito da temperatura 29

1.4.1.4 Efeito do grau de deformação 32

1.4.1.5 Efeito da taxa de deformação 37

1.4.1.6 Efeito do modo de deformação 39

1.5 Martensita induzida por deformação 42

1.5.1 Principais técnicas de avaliação da martensita induzida por deformação

1.5.2 Modelamento matemático da martensita induzida por deformação 48

1.6 Reversão da martensita induzida por deformação 50

1.7 Resistência à corrosão e passivação 52

1.8 Anéis de pistão $\quad 54$

2 MATERIAIS E MÉTODOS $\quad 61$

$\begin{array}{lll}2.1 & \text { Material } & 61\end{array}$

$\begin{array}{lll}2.2 & \text { Análise química } & 61\end{array}$ 
$\begin{array}{lll}2.3 & \text { Solubilização } & 62\end{array}$

2.4 Laminação 63

2.5 Ensaio de tração 63

2.6 Técnicas de análise microestrutural 64

2.6.1 Microscopia óptica 64

2.6.2 Microscopia eletrônica de varredura 65

2.6.3 Difração de raios X 66

$\begin{array}{lll}2.6 .4 & \text { Medidas magnéticas } & 66\end{array}$

$\begin{array}{ll}\text { 2.6.5 Dureza Vickers } & 67\end{array}$

2.7 Ensaios eletroquímicos utilizados em corrosão 67

2.7.1 Espectroscopia de impedância eletroquímica 69

$\begin{array}{lll}\text { 2.7.2 Polarização potenciodinâmica anódica } & 69\end{array}$

$3 \quad$ RESULTADOS E DISCUSSÃO

3.1 Material "como recebido" 71

$\begin{array}{ll}3.1 .1 \text { Composição química } & 71\end{array}$

3.1.2 Caracterização metalográfica 73

$\begin{array}{lll}3.1 .3 & \text { Dureza } & 74\end{array}$

3.1.4 Medidas magnéticas $\quad 75$

3.1.5 Tamanho de grão 75

$\begin{array}{ll}\text { 3.1.6 Difração de raios X } & 75\end{array}$

3.1.7 Formação de martensitas induzidas por deformação 77

3.1.8 Ensaios eletroquímicos utilizados em corrosão 79

3.1.8.1 Espectroscopia de Impedância Eletroquímica 80

3.1.8.2 Polarização potenciodinâmica anódica 83

3.2 Material solubilizado 87

$\begin{array}{lll}\text { 3.2.1 Caracterização metalográfica } & 87\end{array}$

$\begin{array}{lll}3.2 .2 \text { Dureza } & 90\end{array}$

$\begin{array}{ll}\text { 3.2.3 Medidas magnéticas } & 91\end{array}$

3.2.4 Difração de raios $X \quad 91$

3.2.5 Resfriamento sub-zero 93

3.3 Material laminado 95

3.3.1 Caracterização metalográfica 95 
$\begin{array}{ll}\text { 3.3.2 Dureza } & 99\end{array}$

$\begin{array}{ll}\text { 3.3.3 Medidas magnéticas } & 101\end{array}$

$\begin{array}{ll}\text { 3.3.4 Difração de raios X } & 103\end{array}$

3.4 Material tracionado 110

3.4.1 Caracterização metalográfica 112

$\begin{array}{lll}3.4 .2 & \text { Dureza } & 114\end{array}$

$\begin{array}{ll}\text { 3.4.3 Medidas magnéticas } & 116\end{array}$

$\begin{array}{ll}\text { 3.4.4 Difração de raios X } & 117\end{array}$

$\begin{array}{ll}3.4 .5 & \text { Efeito da taxa de deformação } \\ \end{array}$

$\begin{array}{ll}\text { 3.4.6 Efeito do modo de deformação } & 121\end{array}$

$\begin{array}{lll}3.5 & \text { Reversão da martensita } & 123\end{array}$

4 CONCLUSÕES $\quad 125$

$\begin{array}{ll}\text { REFERÊNCIAS } & 127\end{array}$

$\begin{array}{ll}\text { ANEXO A } & 143\end{array}$

$\begin{array}{ll}\text { ANEXO B } & 144\end{array}$ 


\section{INTRODUÇÃO}

No século 21 iniciou-se um período de alta volatilidade no custo do níquel e aumento do consumo de aços inoxidáveis (Als) nos mercados em desenvolvimento, principalmente na Ásia. De acordo com o levantamento estatístico da ISSF ${ }^{1}$, somente a China foi responsável por aproximadamente $25 \%$ da produção mundial de Als e aços resistentes ao calor no ano de 2008. A tabela 1 mostra a distribuição por região da produção mundial de Als e aços resistentes ao calor, em toneladas. Vale ressaltar, que a partir do ano de 2008, a ISSF desmembrou as regiões da Ásia e China, que anteriormente eram contabilizadas juntas, de tão significativa que a China é hoje para o cenário mundial.

Tabela 1 - Produção dos aços inoxidáveis e resistentes ao calor (métrica em $10^{3}$ toneladas)

\begin{tabular}{lcccccc}
\hline Região & 2004 & 2005 & 2006 & 2007 & 2008 & $2009^{*}$ \\
\hline Leste europeu e África & 9,422 & 8,823 & 9,972 & 8,669 & 8,272 & 4,638 \\
Europa ocidental & 318 & 310 & 363 & 364 & 333 & 175 \\
Continente Americano & 2,933 & 2,688 & 3,952 & 2,604 & 2,315 & 1,497 \\
Ásia & 11,897 & 12,498 & 15,074 & 16,200 & $8,068^{\#}$ & $5,043^{\#}$ \\
China & -- & -- & -- & -- & 6,943 & 6,569 \\
Mundo & 24,570 & 24,319 & 28,359 & 27,836 & 26,930 & 17,921 \\
\hline
\end{tabular}

* Valores de 2009 referente ao acumulado até o terceiro trimestre;

\# Valores de produção de toda a Ásia, exceto China.

Devido à importância dos Als, Lo, Shek e Lai [1] publicaram recentemente, em 2009, um trabalho de revisão com mais de 1450 referências, abordando os desenvolvimentos dos últimos 20 anos relacionados a esses materiais.

Os Als são materiais ideais para uma série de aplicações comerciais devido à uma série de fatores como elevada resistência à corrosão e à manchas, exigir baixa manutenção, possuir apelo estético, ter grande capacidade de conformação, versatilidade visual devido às diversas possibilidades de acabamentos de sua superfície (brilhante, fosca, escovada ou colorida), serem recicláveis e por possuírem elevadas propriedades mecânicas. Os Als podem ser conformados em bobinas, folhas, chapas, barras, fios e tubos, dependendo da finalidade da aplicação [2]. Dentre as aplicações em que os Als são utilizados pode-se citar a fabricação de utensílios domésticos, instrumentos cirúrgicos e industriais, além da aplicação nas

\footnotetext{
${ }^{1}$ ISSF significa International Stainless Steel Forum e é um website americano do International Iron and Steel Institute. Pode ser acessado pelo link:<www.worldstainless.org $>$.
} 
indústrias automotiva e aeroespacial estrutural, indústrias química e naval, indústria farmacêutica, indústria têxtil, indústrias de papel e celulose; refinarias de petróleo; material de construção; tanques de fermentação de bebidas alcoólicas, equipamentos para laticínios, equipamentos para instalações nucleares, entre outros.

Dentre os aços Als, a classe dos aços inoxidáveis austeníticos (AIAs) mais utilizada é a série 300 que é caracterizada por conter elevados teores de cromo e de níquel [3]. A fim de minimizar custo, parte do níquel pode ser substituído por outros elementos estabilizadores da austenita como manganês ou nitrogênio, formando outro sistema na família dos AIAs, a da série 200. Esta classe é caracterizada por conter teores de manganês e de nitrogênio mais altos que a série 300 .

Devido à crescente demanda de aplicações de AIAs e à constante pressão para diminuição de custos, novos aços da série 200 têm sido desenvolvidos nas últimas décadas pelas grandes siderúrgicas. Entretanto, poucos trabalhos são realizados para avaliar comparativamente o comportamento em termos da transformação de fase induzida por deformação e da resistência à corrosão entre os aços das séries 200 e 300 . 


\section{OBJETIVO}

Neste trabalho foi realizado um estudo comparativo entre dois AIAs normalizados, o AISI 201 da série 200 e o AISI 304 da série 300. Os objetivos desta dissertação são:

- entender e discutir as influências da composição química, da temperatura, do grau e da taxa de deformação na transformação de fase induzida por deformação por meio de laminação a frio e ensaio de tração no endurecimento por deformação (encruamento);

- avaliar e comparar a resistência à corrosão dos aços selecionados e o comportamento à repassivação. 


\section{Revisão da literatura}

\subsection{Aços inoxidáveis}

Os Als são baseados nos sistemas Fe-Cr, Fe-Cr-C e Fe-Ni-C, mas outros elementos de liga são igualmente importantes. Os Als são compostos por no mínimo $12 \%$ de cromo, teor que garante a formação de uma película passivadora de óxido de cromo contínuo e protetor em sua superfície [4]. Esta película é que confere a principal característica desses materiais, a resistência à oxidação ou corrosão em diferentes temperaturas e meios. Na língua inglesa esta característica deu origem à palavra Stainless Steel, cuja tradução literal significa aço sem mancha. O cromo nos Als possui grande afinidade com o oxigênio. Na superfície do aço forma-se, em nível molecular, uma película de óxido de cromo. A película tem cerca de $13 \mathrm{~nm}$ e é característica por ser passiva, tenaz e renovável, ou seja, se a película for danificada ou removida por qualquer razão, mais cromo contido no aço será exposto ao ar formando mais óxido de cromo [5].

A proporção de ferro e cromo pode variar nos aços inoxidáveis, assim como a adição de elementos de liga como níquel, molibdênio, manganês e nitrogênio podem diversificar e aumentar a faixa de aplicação. Cada classe dos Als possui propriedades mecânicas e físicas únicas e será produzida de acordo com uma norma específica. No total, há cerca de 100 classes diferentes de Als, mas geralmente elas são sub-divididas em cinco principais categorias que os Als podem ser classificados [6]:

A) Aços inoxidáveis martensíticos - são essencialmente ligas de ferro-cromo, sendo este último elemento variando de 11 a 18\% em peso, com teor de carbono acima de $0,1 \%$ em massa, para garantir que microestrutura seja martensítica. Aços martensíticos são característicos pela estrutura tetragonal e são necessários quando a aplicação requer propriedades de boa resistência à tração, fluência e resistência à fadiga combinadas com a resistência à corrosão. Neste grupo podemos citar os aços AISI 403, 410, 416, 420, 422.

B) Aços inoxidáveis ferríticos - são ligas ferro-cromo ferríticas, de estrutura cúbica de corpo centrado (CCC) a todas as temperaturas e que não endurecem por tratamento térmico de têmpera. Geralmente, possuem teor de cromo mais 
elevado do que os martensíticos, em torno de 10 a 30\%, e menor teor de carbono. Neste grupo podemos citar os aços AISI 405, 409, 430, 446, 502.

C) Aços inoxidáveis austeníticos - são ligas a base de ferro-cromo (16-30\%)níquel (8-35\%). Os mais conhecidos AIAs são os da série 300, como por exemplo, os aços AISI 301, 304, 308, 316. Por questão de custo, parte do níquel pode ser substituído por manganês ou nitrogênio, podendo formar outro sistema na família dos AIAs, a série 200. São exemplos os aços AISI 201, 202 e 204. Todos os AIAs, mesmo após tratamento térmico, são predominantemente austeníticos, característicos pela estrutura cúbica de face centrada (CFC) e não magnéticos. $O$ teor de carbono é, em geral, inferior a 0,08\%.

D) Aços inoxidáveis duplex - são ligas cujas microestruturas contendo ferrita e austenita em frações similares são obtidas com composições balanceadas de ferro-cromo (18-27\%)-níquel (4-7\%)-molibdênio(1-4\%) e outros elementos. Fazem parte desta família os aços AISI 329, UNS S32304 e S31803. Esta classe possui menor teor de níquel quando comparado aos aços austeníticos, mas com propriedades mecânicas e de corrosão similares ou superiores aos austeníticos.

E) Aços inoxidáveis endurecidos por precipitação - são ligas ferro-cromo (12$17 \%$ ), níquel (4-8\%), molibdênio (0-2\%) contendo adições de elementos que permitem o endurecimento da martensita de baixo carbono pela precipitação de compostos intermetálicos, como alumínio, cobre, nióbio e/ou titânio.

Certos elementos de liga são adicionados ao sistema básico $\mathrm{Fe}-\mathrm{Cr}$ e $\mathrm{Fe}-\mathrm{Cr}$ $\mathrm{Ni}$, como por exemplo, manganês, nióbio, silício, molibdênio e nitrogênio no intuito de controlar a microestrutura e suas propriedades [7]. Para avaliar o efeito dos elementos de liga que compõem o $\mathrm{Al}$, algumas expressões foram propostas na literatura agrupadas de acordo com seus efeitos. O conceito de cromo equivalente $\left(\mathrm{Cr}_{\text {eq }}\right)$ foi proposto por Schaeffler [8] para avaliar o efeito dos elementos alfagênicos ou ferritizantes nos Als, e o conceito de níquel equivalente $\left(\mathrm{Ni}_{\mathrm{eq}}\right)$ proposto para avaliar o efeito dos elementos gamagênicos ou austenitizantes nos Als.

$$
\begin{aligned}
& \mathrm{Ni}_{\text {eq }}=\% \mathrm{Ni}+0,3(\% \mathrm{Mn})+22(\% \mathrm{C})+14,2(\% \mathrm{~N})+\% \mathrm{Cu} \\
& \mathrm{Cr}_{\text {eq }}=\% \mathrm{Cr}+1,37(\% \mathrm{Mo})+1,5(\% \mathrm{Si})+2(\% \mathrm{Nb})+3(\% \mathrm{Ti})
\end{aligned}
$$


de liga na evolução da microestrutura e indicar as microestruturas mais comuns em Als, pois essas equações levam em consideração a composição equivalente e não só o efeito do níquel e cromo isoladamente [9]. Se os valores de $\mathrm{Cr}_{\text {eq }}$ e $\mathrm{Ni}_{\text {eq }}$ forem colocados em eixos perpendiculares em um gráfico, será obtido o diagrama de Schaeffler.

A figura 1 apresenta o diagrama de Schaeffler [8] construído a partir de amostras soldadas de aços inoxidáveis austeníticos do grupo $\mathrm{Fe}-\mathrm{Cr}-\mathrm{Ni}$, utilizado para prever a quantidade de ferrita que irá se formar na zona fundida. Diagramas semelhantes foram desenvolvidos por DeLong [10] e Hull [11].

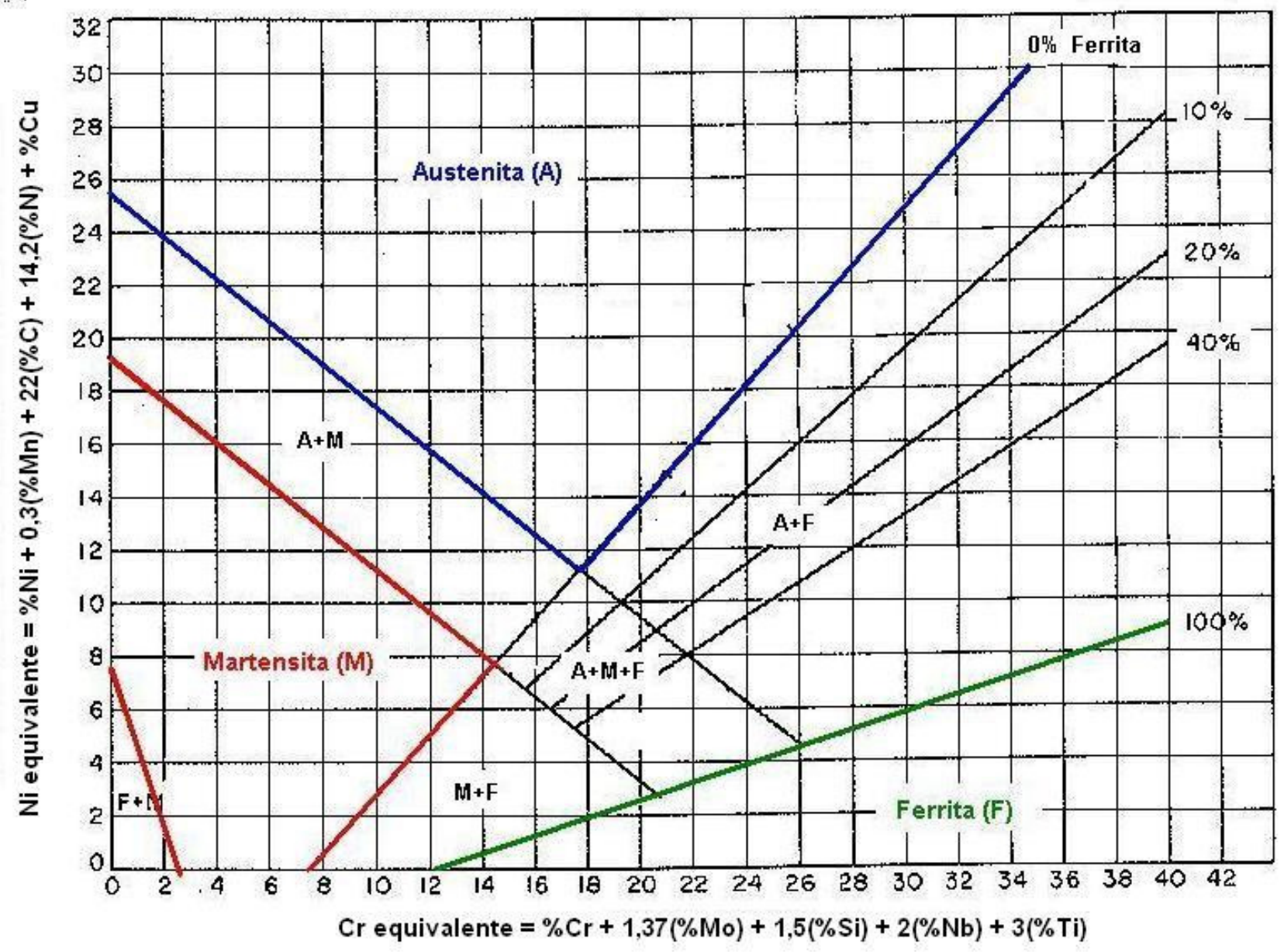

Figura 1 - Diagrama de Schaeffler [12].

O diagrama de Schaeffler descreve a relação entre a composição e a microestrutura dos Als da série 300 e, embora tenha sido desenvolvido para prever o teor de ferrita CCC em metal depositado por solda, ele também fornece uma aproximação prática das fases presentes em metais conformados [13]. 


\subsection{Aços inoxidáveis austeníticos}

Os aços inoxidáveis austeníticos (AIAs) são os mais comuns entre os Als e característicos por possuírem microestrutura austenítica à temperatura ambiente. Esta estrutura é obtida devido à adição de elementos austenitizantes como níquel, manganês e nitrogênio, que estabilizam a austenita mesmo em temperatura ambiente. Esses aços possuem estrutura CFC, são essencialmente paramagnéticos, ou não-magnéticos, na condição recozida e podem ser endurecidos principalmente por conformação a frio [14]. Em geral, possuem excelentes propriedades criogênicas, por não sofrerem transição dúctil-frágil, e boa resistência mecânica em altas temperaturas [15].

O diagrama ternário Fe-Cr-Ni é o diagrama básico dos AIAs [16], conforme mostra a figura 2. Três fases sólidas são consideradas nele, como a austenita $(\gamma)$, a ferrita $(\alpha)$ e a fase sigma $(\sigma)$. Para altas relações $\mathrm{Cr} / \mathrm{Ni}$ a ferrita delta $(\delta)$ também pode precipitar durante tratamentos térmicos entre 550 e $900^{\circ} \mathrm{C}$.

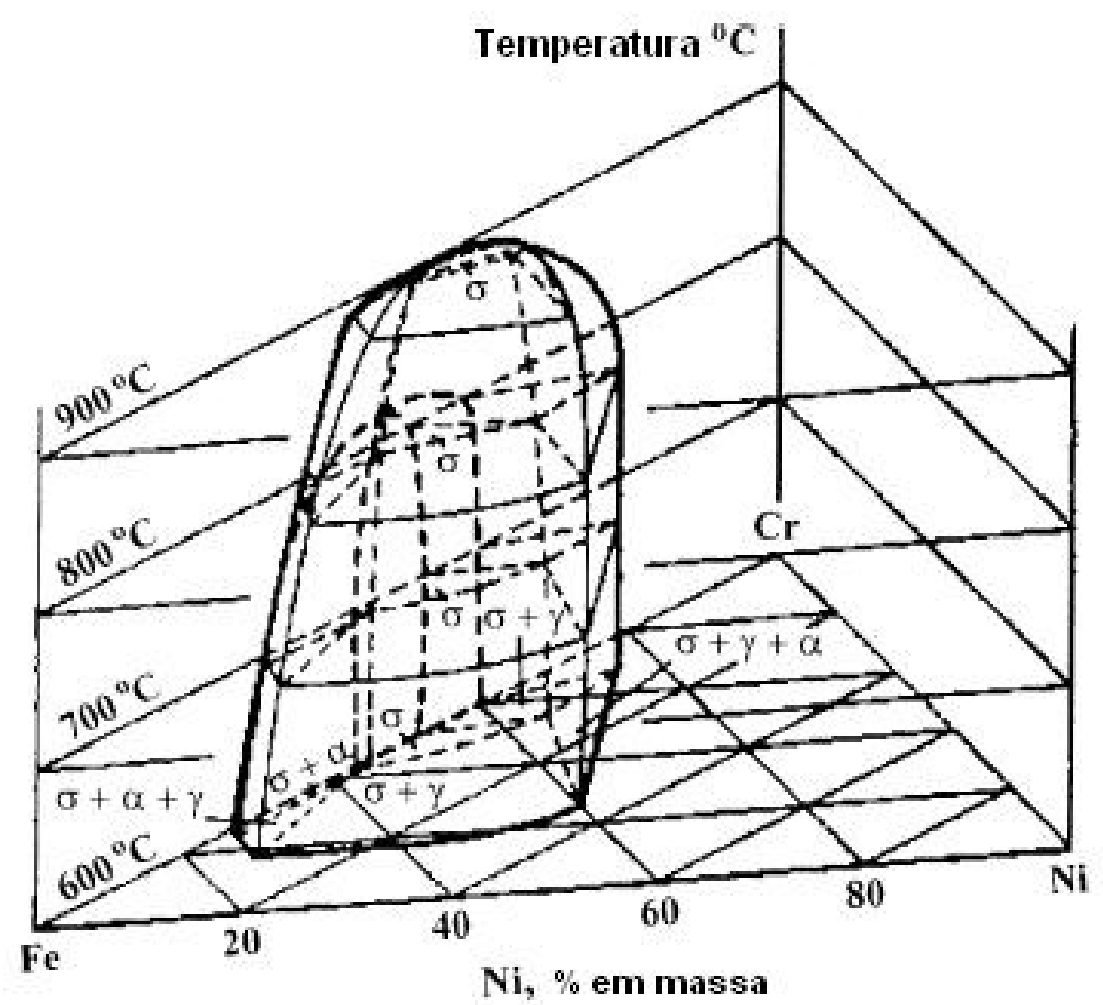

Figura 2 - Visão tridimensional do diagrama Fe-Cr-Ni [17].

Os AIAs comerciais também contêm certa quantidade de carbono, silício, manganês e outros. A adição desses elementos pode alterar a fase de equilíbrio, 
mas basicamente a estrutura é determinada pelos três elementos principais. A figura 3 mostra as secções isotérmicas do diagrama de equilíbrio $\mathrm{Fe}-\mathrm{Cr}-\mathrm{Ni}$ em duas temperaturas. A temperatura de $1100{ }^{\circ} \mathrm{C}$ representa a máxima estabilidade na austenita e é usada como melhor condição de recozimento do aço AISI 304 [2]. Na secção isotérmica a $650{ }^{\circ} \mathrm{C}$, além da ferrita e austenita, nota-se também a presença de fase sigma ( $\sigma$ ) em composições próximas a $50 \%$ de ferro e $50 \%$ de cromo. Nas duas temperaturas selecionadas neste trabalho para representar o sistema Fe-Cr-Ni as fases presentes são a austenita $(\gamma)$ e ferrita $(\alpha)$, sendo que o campo ferrítico localiza-se próximo das composições ricas em cromo e o campo austenítico próximo ao níquel. A literatura [18] apresenta/disponibiliza secções isotérmicas do diagrama de fases ternário $\mathrm{Fe}-\mathrm{Cr}-\mathrm{Ni}$ em mais de 10 temperaturas diferentes, porém disponíveis apenas em temperaturas elevadas (de 650 a $1450{ }^{\circ} \mathrm{C}$ ).

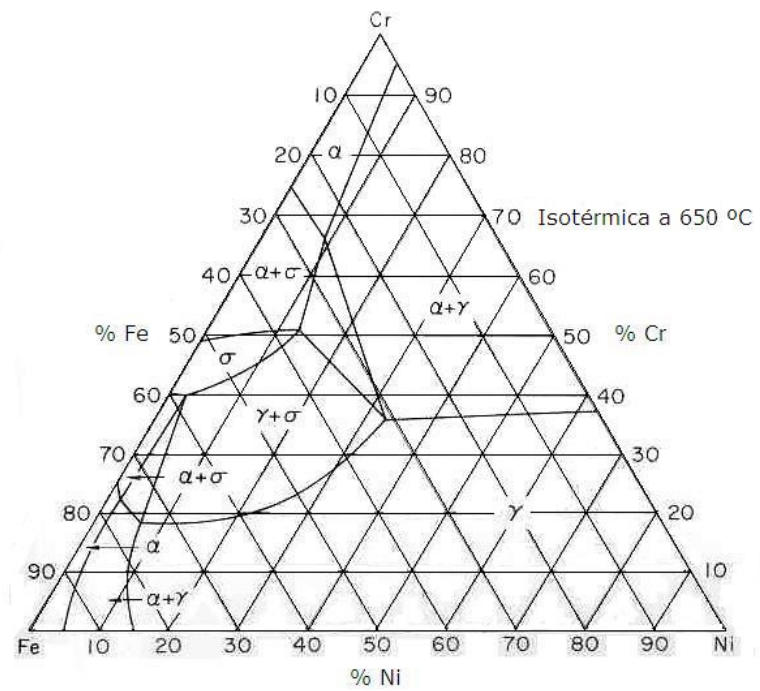

(a)

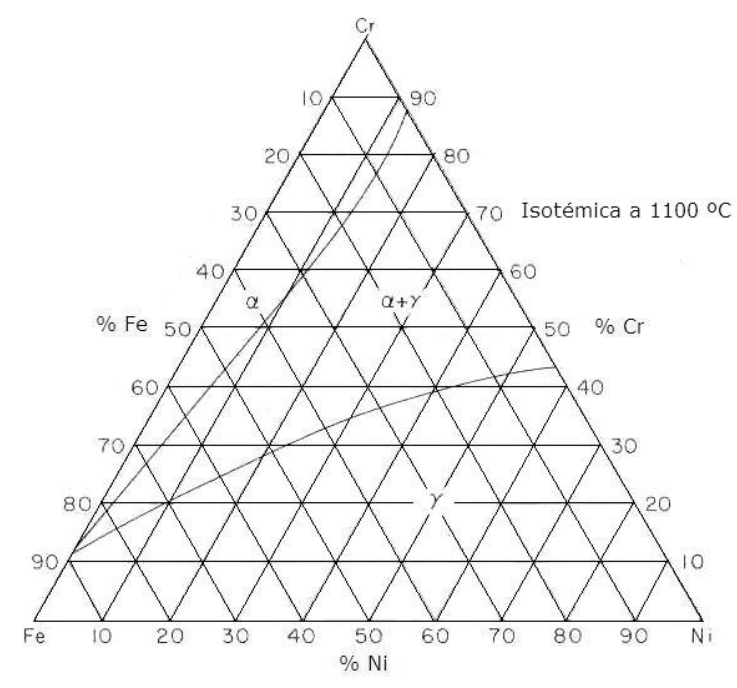

(b)

Figura 3 - Secções isotérmicas do diagrama de fases ternário Fe-Cr-Ni: (a) $650^{\circ} \mathrm{C}$ e (b) $1100{ }^{\circ} \mathrm{C}$ [18].

A classe dos AIAs mais conhecida é a série 300 que pode conter até $35 \%$ de cromo, 16 a $26 \%$ de níquel e até $2 \%$ de manganês [3]. A fim de minimizar custo, parte do níquel pode ser substituído por outros elementos estabilizadores da austenita como manganês ou nitrogênio, formando outro sistema na família dos AIA, o da série 200. Esta classificação é característica por conter teor de nitrogênio mais alto que a série 300, 4 a $15 \%$ de manganês e até $7 \%$ de níquel em massa [14]. A tabela 2 abaixo mostra a faixa de composição química de todos os AIAs classificados de acordo com a American Iron and Steel Institute (AISI) [16]. 
Tabela 2 - Composição química (\% em massa) dos AIAs classificados pela AISI [16].

\begin{tabular}{|c|c|c|c|c|c|c|c|c|}
\hline \multirow[b]{2}{*}{ Tipo } & \multicolumn{8}{|c|}{ Composiçäo (\% em massa) (a) } \\
\hline & $\mathbf{c}$ & Mn & Si & $c_{r}$ & $\mathrm{Ni}$ & $\bar{P}$ & 8 & Outros \\
\hline 201 & 0,15 & $5,5-7,5$ & 1,00 & $16,0-18,0$ & $3,5-5,5$ & 0,06 & 0,03 & $0,25 \mathrm{~N}$ \\
\hline 202 & 0,15 & $7,5-10,0$ & 1,00 & $17,0-19,0$ & $4,0-6,0$ & 0,06 & 0,03 & $0,25 N$ \\
\hline 205 & $0,12-0,25$ & $14,0-15,5$ & 1,00 & $16,5-18,0$ & $1,0-1,75$ & 0,06 & 0,03 & $0,32-0,40 \mathrm{~N}$ \\
\hline 301 & 0,15 & 2,0 & 1,00 & $16,0-18,0$ & $6,0-8,0$ & 0,045 & 0,03 & $\ldots$ \\
\hline 302 & 0,15 & 2,0 & 1,00 & $17,0-19,0$ & $8,0-10,0$ & 0,045 & 0,03 & $\ldots$ \\
\hline $302 \mathrm{E}$ & 0,15 & 2,0 & $2,0-3,0$ & $17,0-19,0$ & $8,0-10,0$ & 0,045 & 0,03 & . \\
\hline 303 & 0,15 & 2,0 & 1,00 & $17,0-19,0$ & $8,0-10,0$ & 0,20 & $0,15 \min$ & $0,6 \mathrm{Mo}(\mathrm{b})$ \\
\hline 303Se & 0,15 & 2,0 & 1,00 & $17,0-19,0$ & $8,0-10,0$ & 0,20 & 0,06 & $0,15 \mathrm{~min} \mathrm{Se}$ \\
\hline 304 & 0,08 & 2,0 & 1,00 & $18,0-20,0$ & $8,0-10,5$ & 0,045 & 0,03 & $\ldots$ \\
\hline $304 \mathrm{H}$ & $0,04-0,10$ & 2,0 & 1,00 & $18,0-20,0$ & $8,0-10,5$ & 0,045 & 0,03 & $\ldots$ \\
\hline $304 \mathrm{~L}$ & 0,03 & 2,0 & 1,00 & $18,0-20,0$ & $8,0-12,0$ & 0,045 & 0,03 & $\ldots$ \\
\hline $304 \mathrm{LN}$ & 0,03 & 2,0 & 1,00 & $18,0-20,0$ & $8,0-12,0$ & 0,045 & 0,03 & $0,10-1,16 \mathrm{~N}$ \\
\hline $302 \mathrm{Cu}$ & 0,08 & 2,0 & 1,00 & $17,0-19,0$ & $8.0-10.0$ & 0,045 & 0,03 & $3,0-4,0 \mathrm{Cu}$ \\
\hline $304 \mathrm{~N}$ & 0,08 & 2,0 & 1,00 & $18,0-20,0$ & $8,0-10,5$ & 0,045 & 0,03 & $0,10-0,16 \mathrm{~N}$ \\
\hline 305 & 0,12 & 2,0 & 1,00 & $17,0-19,0$ & $10,5-13,0$ & 0,045 & 0,03 & $\cdots$ \\
\hline 308 & 0,08 & 2,0 & 1,00 & $19,0-21,0$ & $10,0-12,0$ & 0,045 & 0,03 & $\cdots$ \\
\hline 309 & 0,20 & 2,0 & 1,00 & $22,0-24,0$ & $12,0-15,0$ & 0,045 & 0,03 & $\ldots$ \\
\hline $309 \mathrm{~S}$ & 0,08 & 2,0 & 1,00 & $22,0-24,0$ & $12,0-15,0$ & 0,045 & 0,03 & $\ldots$ \\
\hline 310 & 0,25 & 2,0 & 1,50 & $24,0-26,0$ & $19,0-22,0$ & 0,045 & 0,03 & $\ldots$ \\
\hline $310 S$ & 0,08 & 2,0 & 1,50 & $24,0-26,0$ & $19.0-22.0$ & 0,045 & 0,03 & $\ldots$ \\
\hline 314 & 0,25 & 2,0 & $1,5-3,0$ & $23,0-26,0$ & $19,0-22,0$ & 0,045 & 0,03 & $\ldots$ \\
\hline 316 & 0,08 & 2,0 & 1,00 & $16,0-18,0$ & $10,0-14,0$ & 0,045 & 0,03 & $2,0-3,0 \mathrm{Mo}$ \\
\hline $316 \mathrm{~F}$ & 0,08 & 2,0 & 1,00 & $16,0-18,0$ & $10,0-14,0$ & 0,20 & $0,10 \mathrm{~min}$ & $1,75-2,5 \mathrm{Mo}$ \\
\hline $316 \mathrm{H}$ & $0,04-0,10$ & 2,0 & 1,00 & $16,0-18,0$ & $10,0-14,0$ & 0,045 & 0,03 & $2,0-3,0 \mathrm{Mo}$ \\
\hline $316 \mathrm{~L}$ & 0,03 & 2,0 & 1,00 & $16,0-18,0$ & $10,0-14,0$ & 0,045 & 0,03 & $2,0-3,0 \mathrm{Mo}$ \\
\hline $316 \mathrm{LN}$ & 0,03 & 2,0 & 1,00 & $16,0-18,0$ & $10,0-14,0$ & 0,045 & 0,03 & $2,0-3,0 \mathrm{Mo} / 0,10-0,16 \mathrm{~N}$ \\
\hline $316 \mathrm{~N}$ & 0,08 & 2,0 & 1,00 & $16,0-18,0$ & $10,0-14,0$ & 0,045 & 0,03 & $2,0-3,0 \mathrm{Mo} / 0,10-0,16 \mathrm{~N}$ \\
\hline 317 & 0,08 & 2,0 & 1,00 & $18,0-20,0$ & $11,0-15,0$ & 0,045 & 0,03 & $3,0-4,0 \mathrm{Mo}$ \\
\hline $317 \mathrm{~L}$ & 0,03 & 2,0 & 1,00 & $18,0-20,0$ & $11,0-15,0$ & 0,045 & 0,03 & $3.0-4.0 \mathrm{Mo}$ \\
\hline 321 & 0,08 & 2,0 & 1,00 & $17,0-19,0$ & $9,0-12,0$ & 0,045 & 0,03 & $5 \mathrm{x} \% \mathrm{C} \min \mathrm{Ti}$ \\
\hline $321 \mathrm{H}$ & $0,04-0,10$ & 2,0 & 1,00 & $17,0-19,0$ & $9,0-12,0$ & 0,045 & 0,03 & $5 x \% C \min \mathrm{Ti}$ \\
\hline 330 & 0,08 & 2,0 & $0,75-1,5$ & $17,0-20,0$ & $34,0-37,0$ & 0,04 & 0,03 & $\ldots$ \\
\hline 347 & 0,08 & 2,0 & 1,00 & $17,0-19,0$ & $9,0-13,0$ & 0,045 & 0,03 & $10 \times \% C \min N b$ \\
\hline $347 \mathrm{H}$ & $0,04-0,10$ & 2,0 & 1,00 & $17,0-19,0$ & $9,0-13,0$ & 0,045 & 0,03 & $8 \times \% C \min -1,0 \max \mathrm{Nb}$ \\
\hline 348 & 0,08 & 2,0 & 1,00 & $17,0-19,0$ & $9,0-13,0$ & 0,045 & 0,03 & $\begin{array}{l}0,2 \mathrm{Co} ; 10 \times \% \mathrm{Cmin}_{\mathrm{mb}} \\
0,10 \mathrm{Ta}\end{array}$ \\
\hline $348 \mathrm{H}$ & $0,04-0,10$ & 2,0 & 1,00 & $17,0-19,0$ & $9,0-13,0$ & 0,045 & 0,03 & $\begin{array}{r}0,2 \mathrm{Co} ; 10 \times \% \mathrm{Cmin}- \\
1,0 \max \mathrm{Nb} ; 0,10 \mathrm{Ta}\end{array}$ \\
\hline 384 & 0,08 & 2,0 & 1,00 & $15,0-17,0$ & $17,0-19,0$ & 0,045 & 0,03 & $\ldots$ \\
\hline
\end{tabular}

Adicionar níquel ao AIA é a maneira clássica de estabilizar e preservar a microestrutura austenítica à temperatura ambiente [19]. No entanto, a adição de manganês combinada ao nitrogênio pode resultar no mesmo efeito, com razoável redução de custo se considerar a condição do mercado atual de elevado custo do metal níquel. A classe dos aços ferro-cromo-manganês é caracterizada pela redução do teor de níquel e pela adição de manganês, nitrogênio e cobre, sendo que todos esses elementos são estabilizadores da austenita. Os novos aços mais comuns da série ferro-cromo-manganês são os chamados "4\%Ni" e "1\%Ni". Além do ponto de vista econômico, os Als ferro-cromo-manganês podem oferecer boa conformabilidade e resistência mecânica, dependendo da sua composição. Na verdade, algumas classes, equivalentes aos aços AISI 201, 202 e 205, chegam a oferecer propriedades mecânicas 30\% melhores que o material AISI 304. Entretanto, reduzindo o teor de níquel, reduz-se o teor máximo de cromo no aço, como ilustrado na figura 4. Menor teor de cromo significa menor resistência à corrosão e conseqüentemente redução de possibilidades de aplicação em que o material é 
destinado [19], além de aumentar a possibilidade de ocorrência de sensitização pelo empobrecimento de cromo na matriz podendo causar dificuldade de passivação.

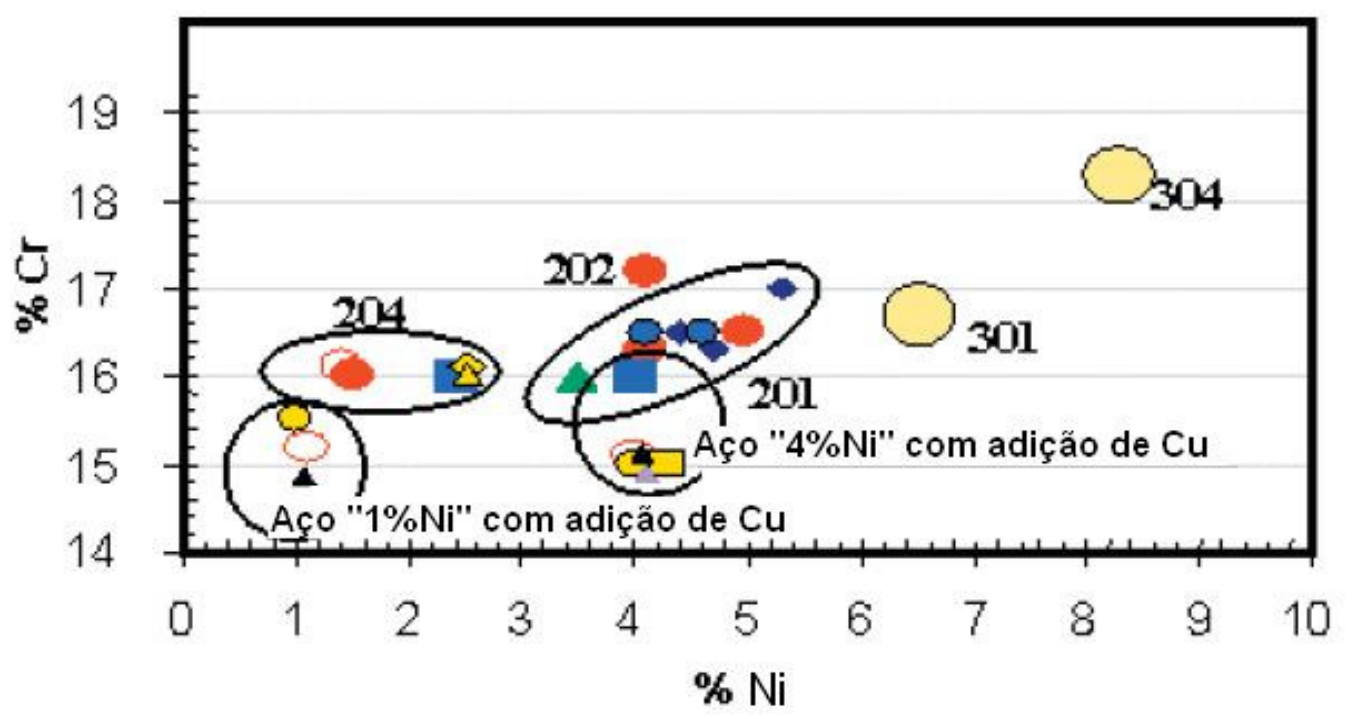

Figura 4 - Equilíbrio do teor de níquel e cromo nas séries 200 e 300 dos AIAs [19].

Nos últimos 60 anos, o aço AISI 304 tornou-se o padrão entre os AIAs. As suas bem conhecidas propriedades de resistência à corrosão, conformabilidade e soldabilidade tornaram viável um crescimento de consumo de aproximadamente $5 \%$ ao ano [19]. Nas décadas de 80 e 90, a série 200 dos AIAs ainda tinha aplicação marginal e fraca expressividade no consumo, apesar de apresentarem boa combinação de resistência mecânica e ductilidade. O alto valor do níquel como mercadoria das últimas três décadas forçou as empresas a buscarem alternativas de desenvolvimento mais acessíveis para aumentar a competitividade. O século XXI apresenta um cenário diferente: muitas novas ligas da classe dos Als ferro-cromomanganês foram desenvolvidas pelas grandes siderúrgicas mundiais para aplicações específicas [19]. Devido ao fato do manganês não ser tão eficiente quanto o níquel como estabilizador da austenita, maior quantidade de adição de manganês é necessária para obter o mesmo efeito. Atualmente, é possível produzir AIAs substituindo grande parte do níquel pela adição combinada de manganês, nitrogênio e cobre para estabilizar a austenita [20]. Em geral, o manganês é utilizado em Als de alto teor de nitrogênio para aumentar a solubilidade do nitrogênio no aço, enquanto o níquel tem efeito contrário, ou seja, diminui a solubilidade do nitrogênio nos Als [21]. A figura 5 mostra a variação dos teores de manganês e níquel de 
acordo com os tipos de aço. Vale ressaltar que os AIAs da série 300 estão a direita inferior caracterizados pelo elevado teor de níquel e baixo teor de manganês, enquanto os AIAs da série 200 estão à esquerda superior do gráfico, caracterizados pelo alto teor de manganês (podendo chegar a 16\% em massa) e baixo teor de níquel.

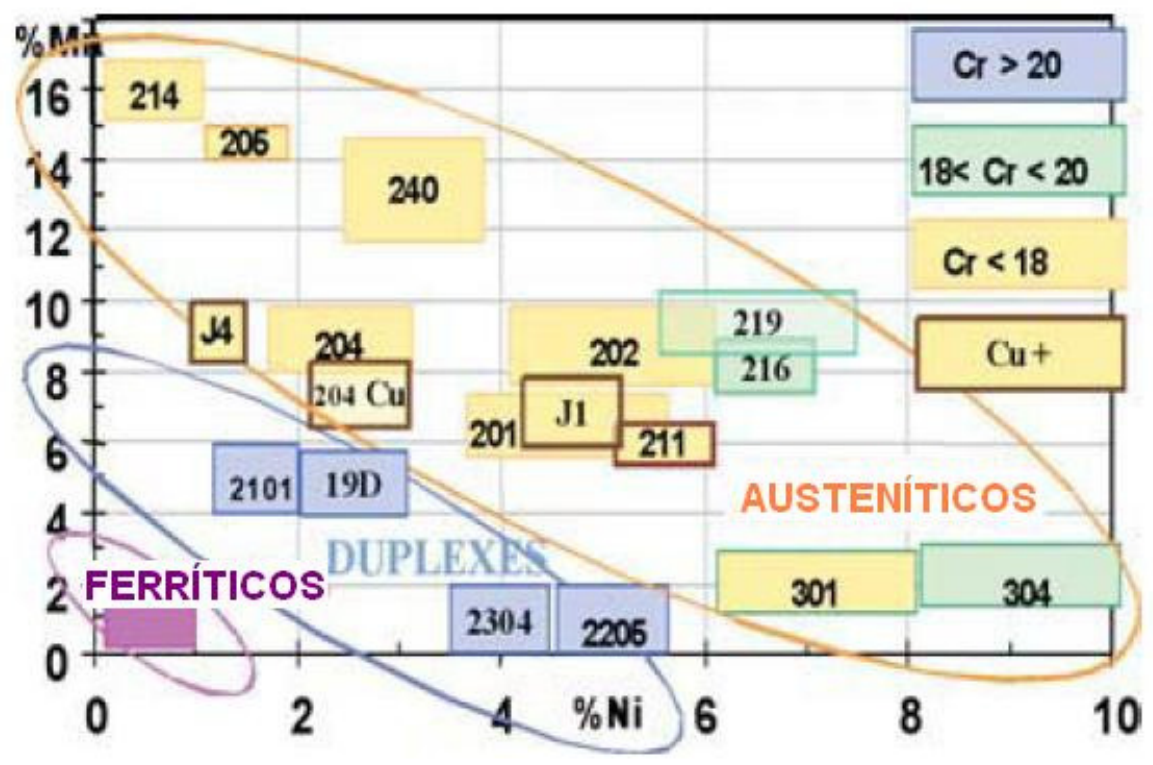

Figura 5 - Teores de níquel e manganês em aços inoxidáveis [19].

A contínua pressão para redução de custo nas empresas siderúrgicas, devido à alta volatilidade no custo do níquel, resultou no desenvolvimento de novas classes de aços austeníticos, com teores menores ainda de níquel e cromo. Um levantamento dos últimos cinco anos referente ao custo dos metais níquel, cromo e manganês (principais elementos que compõem os AIAs das séries 200 e 300) mostra a grande variação cujas siderúrgicas estão sujeitas, conforme ilustra a figura 6. Apesar das grandes oscilações nos custos cujos metais estão sujeitos, ao longo do período de 2005 a 2010 mencionado, em geral o custo do níquel é dez vezes mais caro do que os seus substitutos mais utilizados, como o manganês e cromo [22]. Mesmo considerando a grande variação no custo do níquel nos últimos anos, a sua menor cotação (no início do ano de 2007) coincidiu com o período de maior cotação de manganês. Mesmo assim, o níquel foi cotado dez vezes mais caro que o custo do manganês. O elevado valor do níquel justificou os novos desenvolvimentos de AIA substituindo-o pelo uso de elementos mais baratos e com efeitos similares nas propriedades dos aços, como por exemplo, o manganês. Apenas como 
referência, o custo médio da fita de aço AISI 304 selecionada para este trabalho é de USD 29,00/kg, enquanto a fita de aço AISI 201 é comprada por USD 11,00 / kg, o que representa uma diferença de $230 \%$ (cotação obtida em fevereiro de 2010). Em março deste ano, a última cotação obtida para os principais elementos que compõem os AIAs apresentou os seguintes valores:

- O cromo: USD 1,9/kg;

- O manganês: USD 2,9/kg;

- O níquel: USD $27 / \mathrm{kg}$.

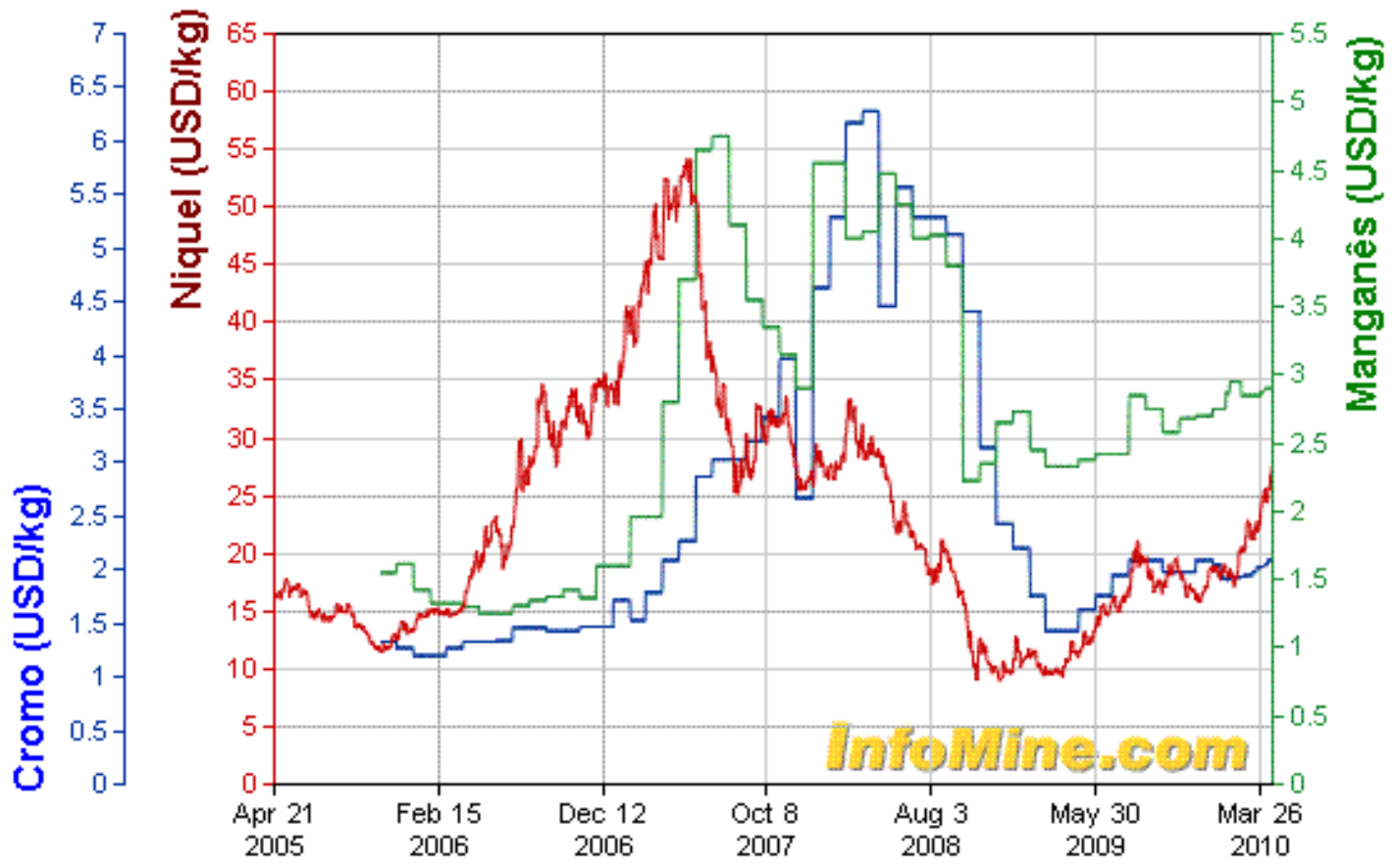

Figura 6 - Variação do custo do Mn, Ni e Cr nos últimos cinco anos desde abril/2005. [22]

Muitas das novas ligas desenvolvidas pelas siderúrgicas ainda não são especificadas por nenhuma classificação internacional. A maioria é apenas identificada pela especificação da empresa produtora ou pelo próprio teor dos elementos [23]. A tabela 3 ilustra a composição química de novas ligas da série 200 desenvolvidas pelas principais siderúrgicas mundiais [23]. É válido observar na tabela 3 que o teor de nitrogênio pode chegar a até 0,25\% em massa e o teor de manganês indicado é de 4 a 12\% em massa na composição dos novos aços, significativamente diferente da série 300 .

$\mathrm{Na}$ literatura há opiniões divergentes em relação à resistência à corrosão das novas ligas da série 200. Porém este aspecto será discutido em maior detalhe 
posteriormente, no item 1.7. Em geral, a aplicação dos aços da série 200 é justificável quando há a necessidade de resistência mecânica aliada a baixo custo. Desta forma, essas novas ligas que ainda não possuem classificação internacional são vulneráveis à ocorrência de corrosão intergranular, corrosão em frestas e corrosão por pites [19]. Claramente essas ligas não foram desenvolvidas visando aplicação de resistência à corrosão, como é habitual para os aços da série 300 . Aplicações em plataformas marítimas de petróleo e até mesmo aplicações que tenham contato direto com a água não são indicadas para esses materiais [19].

Outra vulnerabilidade desses novos aços da série 200 é referente à estabilidade da austenita $[19,21]$. A última coluna da tabela 3 mostra a temperatura $M_{d}$, cujo conceito será discutido posteriormente. Dentre todos os materiais descritos, apenas dois possuem temperatura $M_{d}$ negativa, ou seja, maior estabilidade da austenita referente à transformação de fase da martensita induzida por deformação. Isso significa que a maior parte das ligas possui temperatura $M_{d}$ similar ou acima da temperatura ambiente. Conseqüentemente, se essas ligas forem estampadas, laminadas ou conformadas de qualquer outra maneira a frio, ocorrerá transformação da martensita induzida por deformação e haverá variação dimensional. Aplicação cuja variação dimensional exigida seja nula em temperatura ambiente e que haja solicitação mecânica, também torna inviável o uso dessas novas ligas.

Tabela 3 - Diferentes AIAs da série 200 não especificados por classificação internacional [23].

\begin{tabular}{|c|c|c|c|c|c|c|c|c|c|c|c|c|c|}
\hline Pais & Empresa & Nomenclatura & UNS & $\mathrm{Cr}$ & $\mathrm{Ni}$ & $\mathrm{Mn}$ & $\mathrm{Cu}$ & C & $\mathrm{N}$ & $\mathrm{S}(\mathrm{ppm})$ & $\operatorname{LE}_{0.2}$ & $\mathrm{RT}$ & Md \\
\hline \multirow[t]{3}{*}{ Europa } & U\&A & $16-4 M n$ & S20100 & 16,3 & 4,1 & 6,5 & & 0,09 & 0,16 & 40 & 400 & 770 & 39,99 \\
\hline & U\&A & $16-7 \mathrm{Mn} \dagger$ & S20400 & 16 & 1,6 & 7,5 & 2,9 & 0,05 & 0,19 & $<10$ & 390 & 710 & 28,92 \\
\hline & KTN & $\mathrm{H} 400$ & & 18 & 3,8 & 6,8 & & 0,035 & 0,16 & 7 & 450 & 770 & 48,35 \\
\hline \multirow[t]{3}{*}{ EUA } & & Nitronic 30 & S20400 & 16 & 2,5 & 8,5 & & 0,02 & 0,17 & & 390 & 830 & 101,82 \\
\hline & & Nitronic 19D * & S32001 & 20 & 1,6 & 5 & 0,5 & 0,02 & 0,13 & & 500 & 850 & 105,8 \\
\hline & Allegheny & 219 & S21904? & 21 & 6 & 9 & & 0,03 & 0,25 & & 460 & 780 & $-113,86$ \\
\hline \multirow[t]{3}{*}{ Am. Sul } & Acesita & P201A & - & 15,2 & 1,1 & 9 & 1,7 & 0,1 & 0,1 & $<10$ & 370 & 870 & 95,36 \\
\hline & Acesita & P202A & - & 15,1 & 4 & 7,2 & 1,6 & 0,06 & 0,05 & $<10$ & 310 & 730 & 71,87 \\
\hline & Acesita & P300A † & S20400 & 16,1 & 1,5 & 7,4 & 2,9 & 0,05 & 0,18 & 3 & 370 & 745 & 35,89 \\
\hline \multirow[t]{10}{*}{ Asia } & Jindal & J1 & - & 15 & 4 & 7 & 1,6 & 0,06 & 0,05 & 60 & 300 & 700 & 74,88 \\
\hline & Jindal & JI & - & 16,1 & 4 & 7,1 & 1,7 & 0,06 & 0,07 & 31 & & & 46,85 \\
\hline & Jindal & J4 & - & 15,5 & 1 & 10 & 1,6 & 0,09 & 0,14 & 60 & 470 & 820 & 74,99 \\
\hline & Jindal & $J 4$ & - & 15,9 & 1 & 9,7 & 1,6 & 0,1 & 0,15 & 82 & & & 62,73 \\
\hline & NTK & D10 & - & 17,5 & 4,8 & 3,7 & 2,8 & 0,06 & 0,15 & 10 & 355 & 675 & $-36,51$ \\
\hline & Posco & $204 M$ & S20400 & 16 & 2,5 & 8 & & 0,03 & 0,25 & & 480 & 840 & 64,34 \\
\hline & Posco & $2022 D$ & - & 15,5 & 4,8 & 7,4 & 1,2 & 0,06 & 0,07 & 10 & & & 43,91 \\
\hline & Posco & $2042 D$ & - & 14,4 & 1,04 & 10,3 & 1,2 & 0,05 & 0,16 & 5 & & & 107,28 \\
\hline & $\mathrm{CHX} 1$ & - & - & 15 & 1,1 & 9,6 & 1,7 & 0,1 & 0,14 & 123 & & & 74,7 \\
\hline & $\mathrm{CHX} 2$ & - & - & 11,3 & 1,1 & 12,8 & 0,08 & 0,13 & 0,045 & 60 & & & 176,16 \\
\hline
\end{tabular}

De acordo com a figura 7, essa nova classe de AIAs do sistema ferro-cromo- 
níquel representa quase $10 \%$ da produção mundial dos AIAs. Os AIAs da série 300 , compostos pelo sistema $\mathrm{Fe}-\mathrm{Cr}-\mathrm{Ni}$, ainda representam a maior parte da produção mundial, cerca de $70 \%$. No entanto, ao longo dos cinco primeiros anos desta década, desde quando foi feito o levantamento de produção mundial apresentado na figura 5, os AIAs do sistema ferro-cromo-níquel apresentaram queda de produção, enquanto os aços do sistema ferro-cromo-manganês cresceram no mesmo período [19]. Segundo a ISSF, o potencial de crescimento dos aços do sistema ferro-cromomanganês é grande, quando comparado ao tradicional AIA da série 300, por causa dos produtores asiáticos, em especial a China e Índia, devido à constante busca por alternativas mais baratas aos materiais existentes [20].

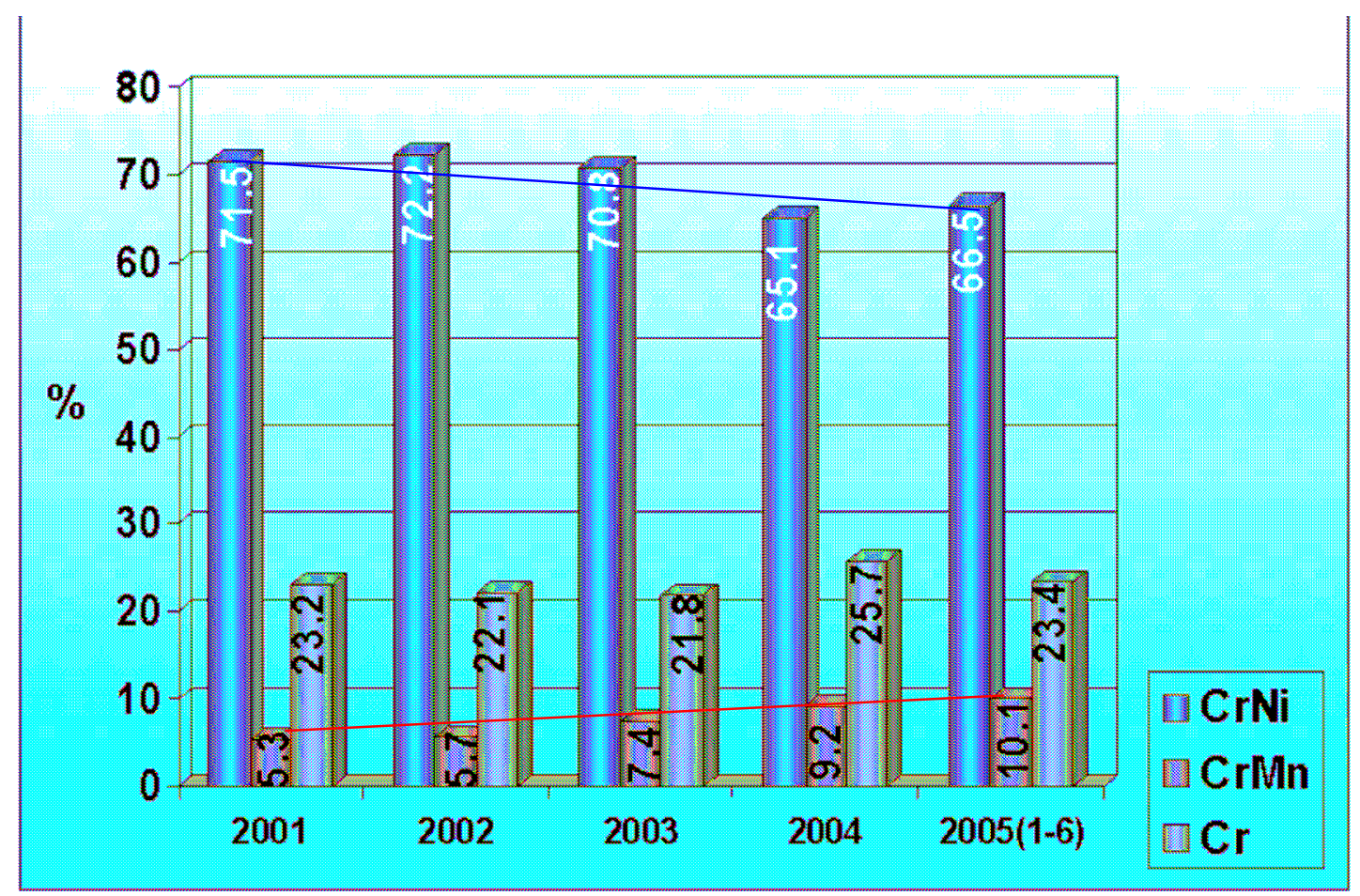

Figura 7 - Produção mundial de aços inoxidáveis [19].

Os AIAs também são geralmente selecionados como materiais para aplicação em implantes devido à combinação de elevada resistência mecânica e elevada corrosão por pite e fresta. O uso dos AIAs da série 300, em específico, pode ser prejudicial ao corpo humano quando comparado com outras ligas devido a presença de níquel e por ele ser o principal elemento de liga desses aços. Os íons de níquel são considerados especialmente tóxicos podendo causar alergias como dermatite de contato e até mesmo câncer [24]. Além disso, o níquel causa reação de sensibilidade em até $10 \%$ das mulheres e $2 \%$ dos homens no mundo [24, 25]. A sensibilidade ao níquel é 
devido ao uso diário de utensílios domésticos, uso de jóias e relógios [25]. Dessa forma, alguns AIAs da série 200, em especial os que não contem níquel em sua composição, são destinados à aplicação como biomateriais [26].

Os biomateriais mais comumente utilizados são os AIAs $316 \mathrm{~L}$, ligas cobaltocromo e ligas de titânio, apesar de originalmente terem sido desenvolvidos para fins industriais. No entanto, esses materiais ainda enfrentam uma série de restrições de uso devido aos potenciais problemas que podem ocorrer, como, toxicidade dos produtos de corrosão, inadequada afinidade para tecidos e células e falta de bio-compatibilidade [26].

Os materiais metálicos implantados num organismo vivo estão expostos à ação corrosiva do meio fisiológico, cuja agressividade é comparável à da água do mar, normalmente aumentando no caso de traumas cirúrgicos, ou infecciosos, devido à uma série de fatores, como a presença de microorganismos, da redução do $\mathrm{pH}$ (acidez), da temperatura, da presença de proteínas. Em condições normais, contudo, dada à passividade das atuais ligas usadas, a velocidade de corrosão é muito baixa. Entre os produtos da degradação destes materiais podem encontrar-se partículas metálicas de tamanhos variados e íons metálicos, os quais podem formar sais ou complexos com elementos ou moléculas presentes no meio biológico [24, 26]. Os efeitos da corrosão dos biomateriais em pessoas implantadas podem ser variados, como a ocorrência de alergias, inflamações, falha da prótese e até mesmo a necessidade de troca da prótese por falta de cicatrização. 


\subsection{Formação da martensita}

A formação de martensita está relacionada ao estado de tensão do processo de deformação. Nos AIAs metaestáveis a martensita pode ser formada a partir do resfriamento abaixo da temperatura ambiente ou em resposta a conformação a frio [27]. A temperatura a partir da qual a austenita transforma-se espontaneamente em martensita pelo resfriamento é chamada de $M_{s}$. Eichelman e Hull [28] desenvolveram uma equação para poder estimar esta temperatura baseada na composição química dos elementos de liga (em \% massa):

$$
\mathrm{M}_{s}\left({ }^{\circ} \mathrm{C}\right)=1305-[1667(\% \mathrm{C}+\% \mathrm{~N})+28(\% \mathrm{Si})+33(\% \mathrm{Mn})+42(\% \mathrm{Cr})+61(\% \mathrm{Ni})]
$$

Esta equação mostra que os solutos substitucionais, como cromo e níquel, têm efeito moderado sobre a $M_{s}$, quando comparados ao intenso efeito dos solutos intersticiais carbono e nitrogênio [27]. Em geral, o teor de nitrogênio é residual para a série 300 dos AIAs, na faixa de 300 a 700ppm. Quando combinados à quantidade de carbono, os dois elementos têm forte efeito na estabilidade da austenita em relação à formação de martensita. A martensita não se forma apenas pelo resfriamento dos AlAs até a temperatura ambiente, pois em geral a temperatura $M_{s}$ é negativa.

Além da temperatura, a deformação é um outro fator que influencia na transformação da austenita para martensita em AlAs. Martensita induzida por deformação pode forma-se em temperaturas superiores à $M_{s}$. Angel [29] estabeleceu o parâmetro $M_{d 30}$ que relaciona a temperatura abaixo da qual a tensão por deformação induz à transformação martensítica com a composição química (\% em massa) direcionados aos aços $18 \% \mathrm{Cr}-8 \% \mathrm{Ni}$, conforme equação 4 :

$$
\begin{aligned}
& \mathrm{M}_{\mathrm{d} 30 / 50}\left({ }^{\circ} \mathrm{C}\right)=413-[462(\% \mathrm{C}+\% \mathrm{~N})+9,2(\% \mathrm{Si})+8,1(\% \mathrm{Mn})+13,7(\% \mathrm{Cr})+9,5(\% \mathrm{Ni})+ \\
& +18,5(\% \mathrm{Mo})]
\end{aligned}
$$

onde $\mathrm{M}_{\mathrm{d} 30 / 50}$ é a temperatura pela qual $50 \%$ da martensita $\alpha$ 'é produzida após $30 \%$ 
de deformação.

A estabilidade da austenita em relação à transformação martensítica é geralmente medida pelas temperaturas Ms e Md30 [30]. Lichtenfeld e co-autores [31] publicaram os valores calculados de Ms e Md30 para diferentes AIAs da série 300, conforme tabela 4.

Tabela 4 - Temperatura de transformação martensítica para alguns aços AIAs [31].

\begin{tabular}{cccccc}
\hline $\begin{array}{c}\text { Temperatura de } \\
\text { transformação }\end{array}$ & Referência & AISI 309 & AISI 304L & AISI 301LN & AISI 304 \\
\hline $\mathrm{M}_{\mathrm{s}}\left({ }^{\circ} \mathrm{C}\right)$ & Eichelman & $\#$ & -135 & -87 & -173 \\
$\mathrm{M}_{\mathrm{d}}\left({ }^{\circ} \mathrm{C}\right)$ & Angel & -107 & 35 & 37 & 20 \\
\hline
\end{tabular}

\# temperatura abaixo de zero absoluto.

A ocorrência de martensita induzida por deformação dos AIAs é influenciada pela composição química e pelos parâmetros referentes à conformação a frio, como grau de deformação, tipo de deformação, temperatura e o estado de tensão [32]. A influência de cada um dos fatores será discutida em seguida. 


\subsection{Endurecimento por deformação a frio}

O conhecimento detalhado da microestrutura dos AIAs encruados é de fundamental importância para o entendimento da transformação de fase induzida por deformação.

De acordo com Haeßner e co-autores [33] durante a deformação a frio dos metais, cerca de $5 \%$ da energia empregada na deformação é armazenada no material, na forma de defeitos cristalinos, como discordâncias e defeitos de empilhamento. Padilha e Siciliano Jr. [34] afirmam que a densidade e distribuição desses defeitos gerados na deformação plástica dependem de vários fatores como: a estrutura cristalina do metal, a sua pureza, as fases presentes, e da quantidade, temperatura, velocidade e modo de deformação, além da energia de defeito de empilhamento.

\subsubsection{Fatores que afetam a microestrutura do metal}

Os principais fatores que afetam a microestrutura no endurecimento por deformação serão discutidos neste trabalho. Os itens selecionados para discussão foram a energia de defeito de empilhamento, composição química, temperatura, grau, taxa e modo de deformação [34].

\subsubsection{Efeito da energia de defeito de empilhamento}

A estrutura cristalina dos AIAs é CFC e pode ser obtida por meio de empilhamento de planos de máxima densidade atômica $\{111\}$ arranjados em uma seqüência regular do tipo $A B C A B C A B C$... Esta seqüência de empilhamento pode ser localmente alterada, por exemplo, por deformação plástica, dando origem a um defeito de empilhamento [35] como ilustra a figura 8. A alteração do empilhamento pode resultar na retirada de parte de um plano de átomos ou na introdução de parte de um plano de átomos, chamados de defeito de empilhamento intrínseco e extrínseco, respectivamente. 
C

B

A

C

$B$

A

C

B

A

(a)
A

C

B

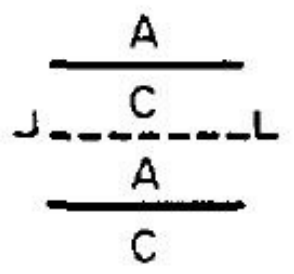

B

A

(b)
B

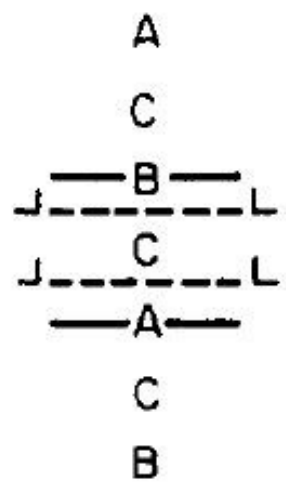

A

(c)

Figura 8 - Defeito de empilhamento na estrutura CFC. (a) empilhamento regular da estrutura CFC, (b) falha intrínseca e (c) falha extrínseca [36].

Os defeitos de empilhamento são delimitados por discordâncias parciais [35], conforme mostra a figura 9. A energia de defeito de empilhamento (EDE) pode ser determinada experimentalmente medindo-se a distância entre as discordâncias parciais com auxílio de microscopia eletrônica de transmissão (MET) [37].

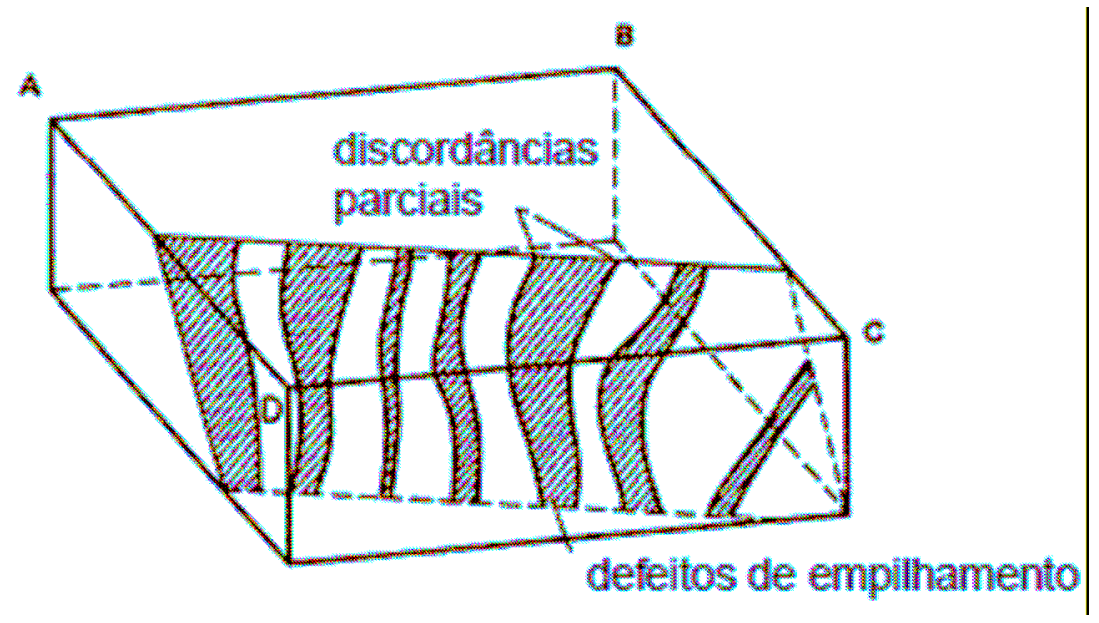

Figura 9 - Discordâncias parciais delimitando defeitos de empilhamento [37].

Segundo Padilha [37], a influência da EDE é muito significativa na propriedade dos materiais. Quanto maior for esta energia (a unidade da EDE é energia por unidade de área; por exemplo, $\mathrm{mJ} / \mathrm{m}^{2}$ ou erg/ $\mathrm{cm}^{2}$ ), mais próximas estão as discordâncias parciais, minimizando a área defeituosa, facilitando 0 escorregamento com desvio ("dislocation cross-slip") e a escalada ("dislocation 
climb"); as discordâncias têm maior mobilidade e tendem a aniquilar-se com discordâncias de sinais opostos. Como conseqüência desses fatores, um metal de alta EDE apresenta menor densidade de discordâncias, tendo caminho médio livre maior que um metal de baixa EDE. Já os metais de baixa EDE apresentam maior densidade de discordâncias, maior energia armazenada na deformação e menor mobilidade devido a distância das discordâncias parciais ser mais afastadas entre si. Como conseqüência, a ocorrência de escorregamento com desvio ou escalada se torna mais difícil e a taxa de encruamento aumenta; a distribuição das discordâncias resultante é mais homogênea e com menor tendência de formação de arranjo celular [37].

A ocorrência de maclas por deformação também depende da EDE e do tamanho de grão (TG). A ocorrência de maclas de deformação é uma maneira alternativa de deformação plástica quando o deslizamento de planos se torna difícil. Elas são raramente formadas em metais de estrutura CFC. Para que haja a ocorrência em materiais com esta estrutura é necessária uma combinação de fatores como altas velocidades de deformação em temperaturas baixas e orientação cristalográfica desfavorável ao escorregamento [37].

As condições de baixa EDE e grande TG favorecem a ocorrência de maclas por deformação. Em metais CFC de baixa EDE, caso típico dos AIAs, a densidade de discordâncias e o encruamento aumentam quando conformados a frio. Dependendo do valor da EDE, duas microestruturas podem ser formadas após laminação a frio dos AIAs. Para altos valores de EDE espera-se a formação de arranjo celular sem ocorrência de martensita induzida por deformação, ou seja, não há formação de martensitas $\varepsilon$ e $\alpha$, fato que pode ser comprovado na figura 10 . A microestrutura típica de materiais de baixa EDE, como AIAs, é de distribuição de discordância planar com martensita induzida por deformação [32]. 


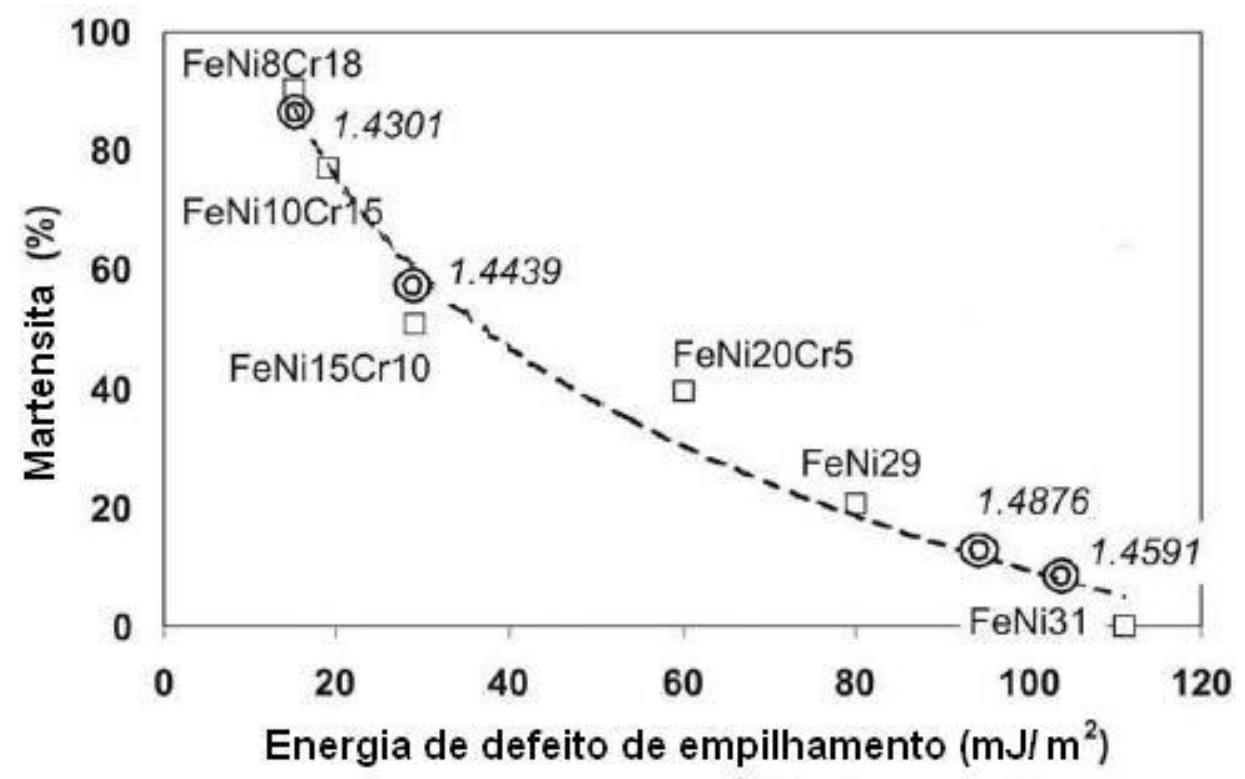

Figura 10 - Correlação entre martensita induzida por deformação e EDE [38].

A EDE influi diretamente na natureza, na densidade e distribuição dos defeitos do reticulado cristalino, além da favorecer a formação de martensita na deformação a frio dos AIAs [32]. Os AIAs são conhecidos por terem baixa EDE, quando comparado aos outros metais com estrutura CFC, conforme indica a tabela 5. A EDE da austenita, em função da composição do aço e da temperatura, é um dos fatores mais importantes que controla a característica do mecanismo da deformação.

Tabela 5 - EDE de metais e ligas de estrutura CFC.

\begin{tabular}{cccc}
\hline Material & Composição nominal (\% em massa) & EDE $\left(\mathrm{mJ} / \mathrm{m}^{2}\right)$ & Referência \\
\hline AISI 301 & Fe-16\%Cr-6\%Ni $(<2 \% \mathrm{Mn})$ & 6,0 & {$[39]$} \\
AISI 304 & Fe-18\%Cr-8Ni $(<0,08 \% \mathrm{C},<2 \% \mathrm{Mn})$ & 18,0 & {$[39]$} \\
AISI 304L & Fe-18\%Cr-8Ni $(<0,03 \% \mathrm{C},<2 \% \mathrm{Mn})$ & 18,0 & {$[39]$} \\
AISI 309 & Fe-22\%Cr-12\%Ni $(<2 \% \mathrm{Mn})$ & 45,0 & {$[31]$} \\
AISI 310S & Fe-25\%Cr-19\%Ni $(<2 \% \mathrm{Mn})$ & 94,0 & {$[40]$} \\
AISI 316 & Fe-17\%Cr-13\%Ni-2\%Mo $(<2 \% \mathrm{Mn})$ & 78,0 & {$[40]$} \\
Alumínio & -- & 163,0 & {$[37]$} \\
Níquel & -- & 220,0 & {$[37]$} \\
\hline
\end{tabular}

Se a EDE aumenta, o modo dominante de deformação muda da formação de martensita- $\varepsilon$ para maclas de deformação e escorregamento. Além disso, a diferença 
de tensão aplicada modifica a taxa de nucleação da martensita- $\alpha^{\prime}$ [41].

Schramm e Reed [40] propuseram uma relação entre a composição química dos principais elementos de liga dos AIAs comerciais e a EDE, conforme indica a equação 5:

$\operatorname{EDE}\left(\mathrm{mJ} / \mathrm{m}^{2}\right)=-53+6,2(\% \mathrm{Ni})+0,7(\% \mathrm{Cr})+3,2(\% \mathrm{Mn})+9,3(\% \mathrm{Mo})$

A equação acima foi obtida a partir de análise de regressão de valores de EDE medidos pela técnica de difração de raios $X$ [42]. A equação 5 considera os solutos substitucionais dos materiais, porém não contempla os solutos intersticiais, como carbono e nitrogênio. Por esta razão, aços como AISI 304 e AISI 304L que se diferem pelo teor de carbono para evitar a sensitização, possuem EDE similares quando calculadas pela equação 5. Na literatura, o trabalho de Schramm e Reed [40] é considerado referência para o cálculo da EDE, apesar de haver trabalhos com opiniões divergentes [43]. Vitos, Nilsson e Johansson [43] afirmam que não há uma equação universal relacionando a composição dos aços para medir a EDE. O efeito dos elementos de liga na EDE é obtido como um equilíbrio entre três conceitos fundamentais: em termos magnéticos, volumétricos e eletrônicos. O mesmo elemento de liga pode causar efeito oposto na EDE quando combinado com diferentes composições químicas. Gavriljuk, Petrov e Shanina [44] propuseram uma correlação entre a EDE e o efeito do elemento nitrogênio que tem influência direta em AIA, principalmente na série 200.

$O$ valor da EDE calculado para os AIAs pode ser interpretado como a estabilidade termodinâmica do material para efeito de comparação entre metais. A revisão feita para este trabalho não encontrou referência da EDE para AIAs da séries 200 na literatura. Desta forma, no item "Resultados" adiante estão os valores da EDE para os aços AISI 201 e AISI 304 calculados a partir da equação 5. A análise comparativa desses resultados é de grande importância para o andamento deste trabalho. 


\subsubsection{Efeito da composição química}

Os efeitos dos elementos de liga nos aços e ligas especiais não apenas alteram as fases ou constituintes presentes em equilíbrio, mas também na maneira e velocidade com que as fases se formam. A presença de elementos de liga pode alterar a própria característica das fases presentes [45]. Em geral, costuma-se classificar os elementos de liga dos aços em dois tipos, o tipo A (elementos estabilizadores da ferrita, também chamados de ferritizantes ou alfagênicos) e tipo $B$ (elementos estabilizadores da austenita, também chamados de austenitizantes ou gamagênicos) [42], conforme figura 11 :

- Tipo $\mathbf{A}_{1}$ ou campo austenítico aberto - Os elementos de liga que compõem esta classificação aumentam a faixa de temperatura para a austenita estável, pela diminuição da temperatura de transformação $\gamma \rightarrow \alpha$ e aumento da temperatura da transformação $\gamma \rightarrow \delta$. A este grupo pertencem uma série de elementos de liga, como níquel, manganês e cobalto.

- Tipo $A_{2}$ ou campo austenítico expandido - Carbono e nitrogênio são os elementos mais importantes deste grupo. O campo austenítico é expandido até a formação de um composto de ferro.

- Tipo $B_{1}$ ou campo austenítico fechado - Uma série de elementos restringe a formação de austenita, favorecendo a expansão do campo ferrítico. Assim, o campo austenítico apresenta-se totalmente circundado pela região de duas fases $(\gamma+\alpha$ ou $\gamma+\delta)$. São exemplos o silício, vanádio, titânio, cromo e molibdênio.

- Tipo $\mathbf{B}_{2}$ ou campo austenítico contraído - O campo austenítico é interrompido pela formação de compostos de ferro. São exemplos o boro, enxofre e zircônio. 


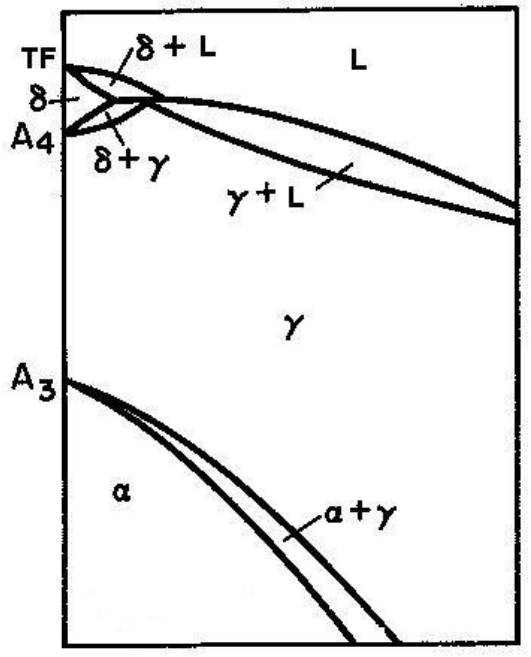

(a) Tipo A1

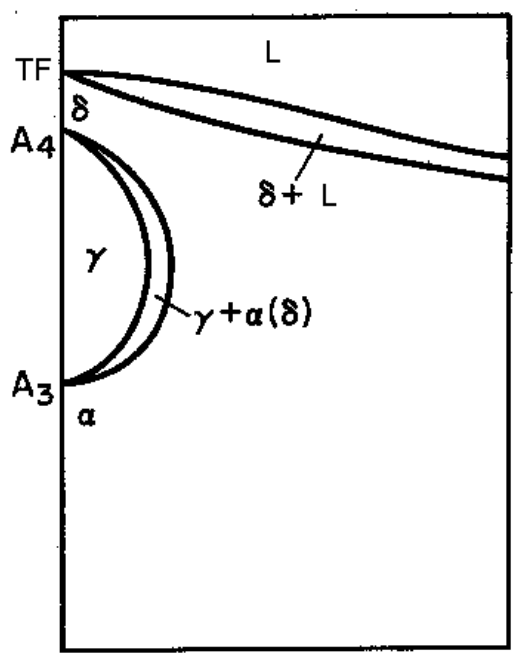

(c) Tipo B1

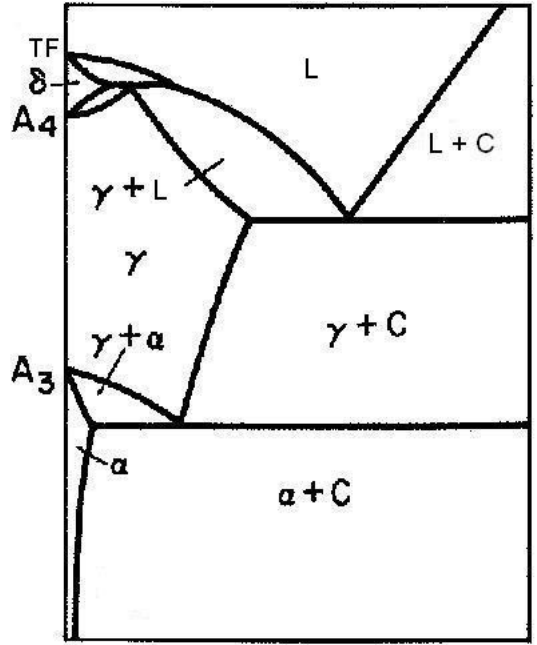

(b) Tipo A2

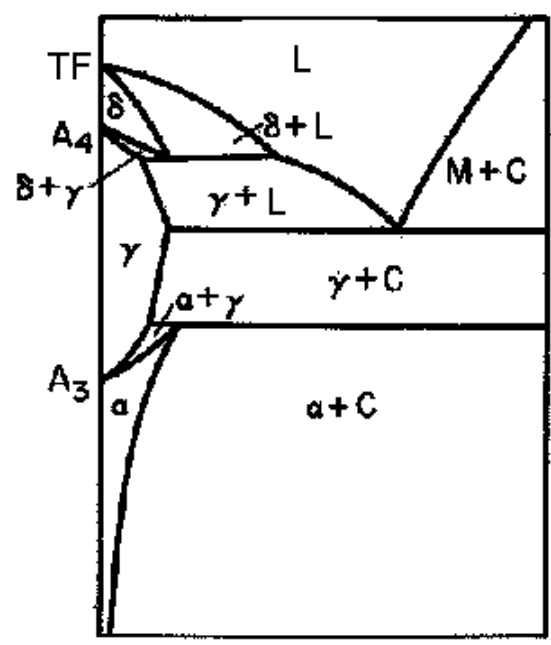

(d) Tipo B2

Figura 11 - Tipos de diagramas de equilíbrio para o sistema ferro-elementos de liga [42].

O comportamento geral dos elementos de liga é melhor descrito por meio da termodinâmica, onde $\Delta \mathrm{H}$ é a entalpia, que é o calor absorvido por unidade de soluto dissolvido na fase $\gamma$ menos o calor absorvido por unidade de soluto dissolvido na fase $\alpha$, isto é, $\Delta H=H_{\gamma}-H_{\alpha}$. Para os elementos formadores de ferrita, $H_{\alpha}<H_{\gamma}$ e $\Delta H$ é positivo; para os elementos formadores de austenita, $\mathrm{H}_{\alpha}>\mathrm{H}_{\gamma}$ e $\Delta \mathrm{H}$ é negativo [46]. A figura 12 apresenta as tendências relativas dos elementos de liga para a formação da austenita e ferrita. 

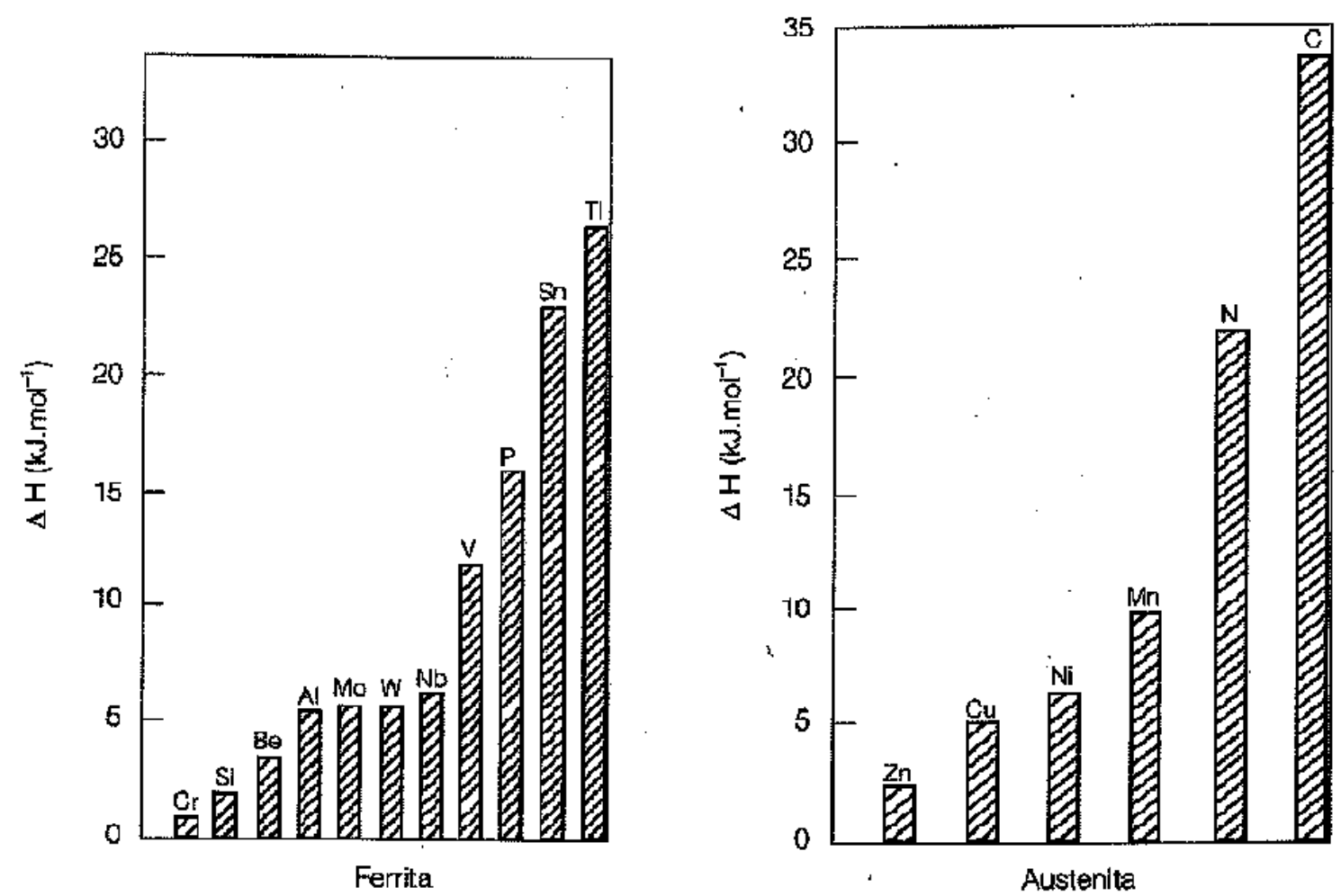

Figura 12 - Tendência relativa dos elementos de liga (a) para formação de ferrita e (b) para formação de austenita. [45].

Baseado na figura 12, os elementos com maiores efeitos austenitizantes são o carbono e o nitrogênio, seguidos pelo manganês, níquel e cobre. Pequenas adições dos elementos carbono e nitrogênio têm maior efeito do que grande quantidade de cobre ou zinco. Apesar do elemento manganês não promover a transformação da ferrita em austenita em temperaturas elevadas, ele certamente tende a estabilizar a austenita em relação à transformação martensítica em baixas temperaturas. Adicionalmente, o manganês favorece a solubilidade do nitrogênio nos AIAs, tornando viável a fabricação da série 200 dos AIAs, característicos por utilizar baixo teor de níquel [3, 21]. Da mesma forma, os elementos com maior efeito ferritizante são o titânio, fósforo e vanádio. Nesta categoria estão os elementos formadores de carbonetos como tungstênio e nióbio.

A maioria dos elementos de liga que se encontra em solução sólida na austenita, abaixa a temperatura $\mathrm{M}_{\mathrm{s}}$ com exceção do alumínio e do cobalto. Os solutos intersticiais como carbono e nitrogênio têm maior efeito de estabilizar a austenita do que os solutos substitucionais [46]. Dentre as vantagens do uso do nitrogênio pode citar a possibilidade de reduzir o teor de níquel devido à natureza do nitrogênio em estabilizar a austenita, o aumento da resistência dos aços devido ao 
endurecimento por solução sólida e o aumento da resistência à corrosão localizada [47].

O aumento do limite de escoamento causado pela adição de elementos em solução sólida substitucional, particularmente os elementos estabilizadores da austenita, é moderado. O endurecimento é causado devido à dificuldade da movimentação das discordâncias quando os solutos substitucionais distorcem o reticulado cristalino. O método mais efetivo para o aumento do limite de escoamento de AIAs é pela adição de solutos intersticiais como nitrogênio, carbono e boro, conforme indica a figura 13. A adição de cerca de 0,1\% em peso desses elementos pode levar ao ganho de até 50MPa [48]. Em geral, os AIAs abrangem um vasto campo de propriedades mecânicas, sendo que os AIAs da série 200 possuem limite de escoamento maiores que os aços da série 300 por conterem maior quantidade de nitrogênio, conforme indica a figura 14.

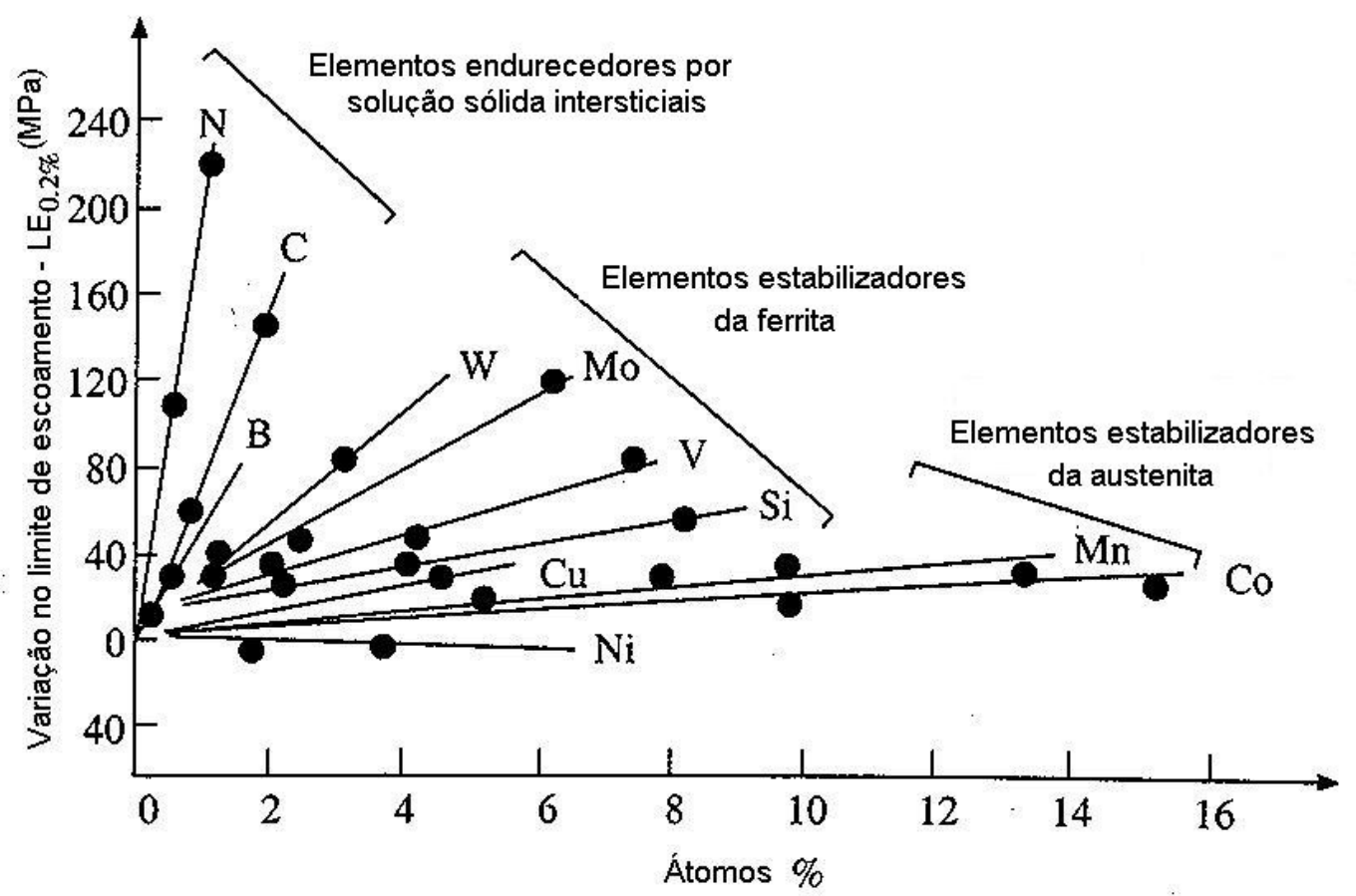

Figura 13 - Efeito do endurecimento por solução sólida na austenita. [48]

O elemento níquel tem um efeito direto no aumento da energia de defeito de empilhamento e na da formação de martensita induzida por deformação [40]. Quanto maior o teor de níquel nos AIAs, maior o valor da sua EDE.

O carbono tem grande influência em AIAs, pois funciona como estabilizador da austenita e aumenta a resistência por endurecimento em solução sólida. Quando 
o aço AISI 316 é aquecido a $1100{ }^{\circ} \mathrm{C}$, o limite de solubilidade do carbono na austenita aumenta para valores até $0,1 \%$ em massa, enquanto para valores de 750 ${ }^{\circ} \mathrm{C}$ a solubilidade cai para 50ppm [49]. Os AIAs apresentam significativo endurecimento após deformação a frio, devido à baixa energia de defeito de empilhamento deste tipo de aço e à formação de martensita induzida por deformação. A tendência de aumentar o endurecimento diminui com o teor de níquel e aumenta com o teor de carbono [50].

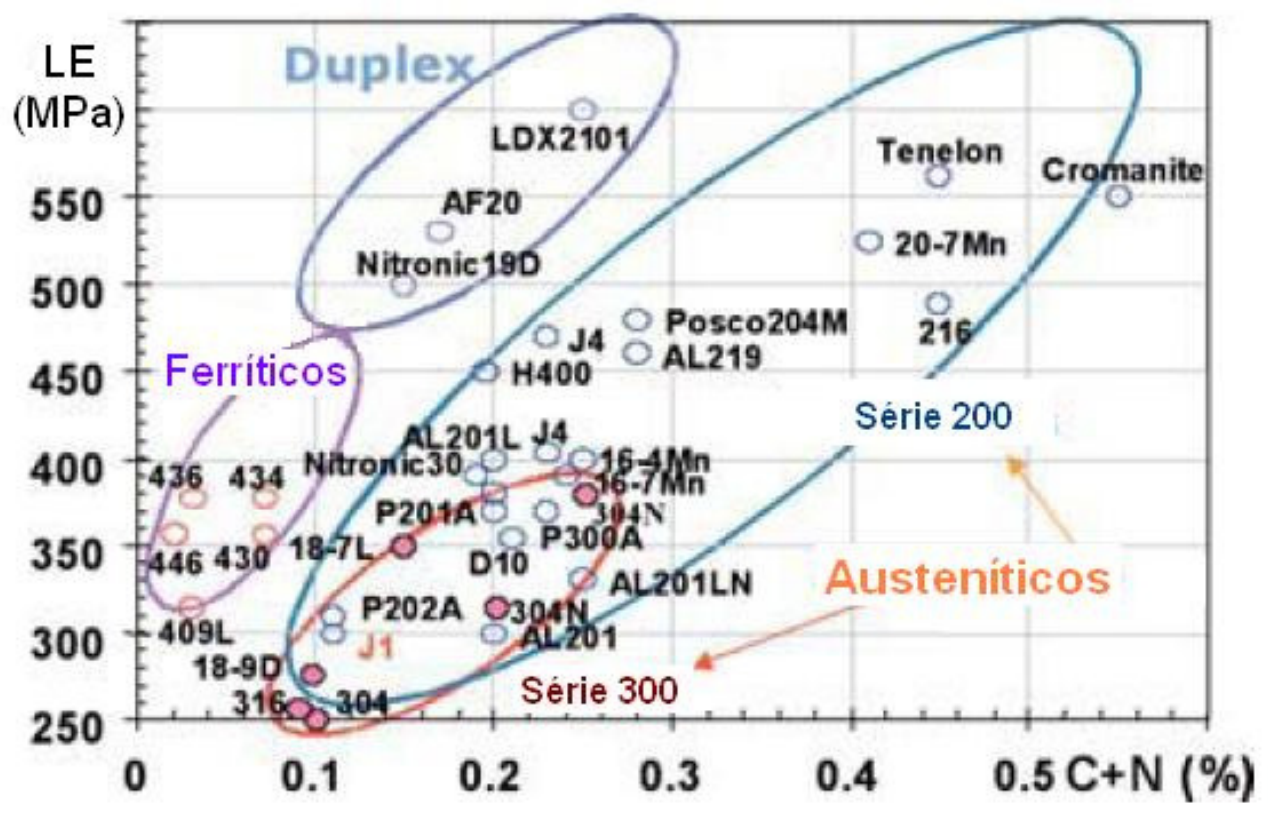

Figura 14 - Variação do limite de escoamento com o teor de carbono e nitrogênio. [23].

Devido à excelente combinação de ductilidade, resistência mecânica e tenacidade dos AIAs contendo altos teores de nitrogênio, vale mencionar que muitos trabalhos na literatura $[21,51,52]$ recomendam a possibilidade de sua aplicação onde alta resistência aliada à tenacidade são necessárias, além de elevada resistência à corrosão, mesmo em elevadas temperaturas. A figura 15 mostra comparativamente os limites de escoamento e resistência de diversos aços em função do teor de nitrogênio. O elemento nitrogênio é mais eficaz no endurecimento por solução sólida e conseqüentemente, afeta positivamente nas propriedades mecânica, fadiga e fluência. Por esta razão, os AIAs de alto teor de nitrogênio são indicados para aplicação de anéis retentores e parafusos de elevada resistência por exemplo [21].

Schramm e Reed [40] afirmam que a presença dos elementos níquel e 
carbono tendem a aumentar a EDE, enquanto que a adição dos elementos cromo, silício, manganês e nitrogênio diminuem a EDE dos AIAs.

Adições de cobre têm sido consideradas em novos desenvolvimentos das ligas da série 200. Este elemento é utilizado para composições de aços contendo níquel, manganês e cromo com baixo teor de nitrogênio, resultando em propriedades mecânicas inferiores aos do AIA com elevado teor de nitrogênio [23], facilitando o processo de conformação a frio. Choi e Jin [53] também afirmam que o cobre aumenta a EDE dos AIAs.

Kim e co-autores [54] estudaram o efeito dos elementos níquel e carbono na resistência ao desgaste. Foi proposta uma relação entre a energia crítica necessária para que ocorra a transformação da austenita para martensita induzida por deformação (CESIMIT) e a composição dos elementos de liga dos AIAs Fe-Ni-C, conforme descrição da equação 6.

CESIMIT $=-6,0+3,6(\% \mathrm{C})+0,23(\% \mathrm{Ni})\left(10^{4} \mathrm{~kJ} / \mathrm{m}^{3}\right)$

A equação 4 mostra que com o aumento da concentração dos elementos carbono e níquel, a CESIMIT diminui [54]. A influência do carbono na CESIMIT é cerca de dezesseis vezes maior que o efeito do níquel.

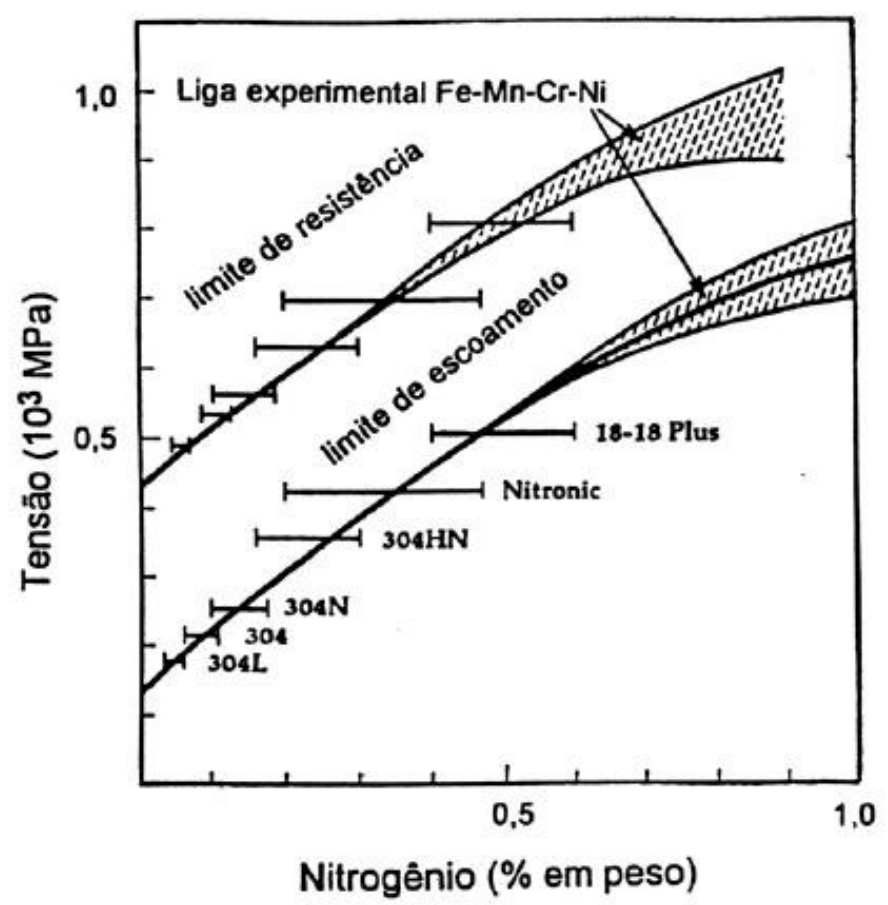

Figura 15 - Efeito do nitrogênio na resistência mecânica dos AIAs.[55] 


\subsubsection{Efeito da Temperatura}

Singh [56] afirma que a dureza final do aço AISI 304 deformado a $50 \%$ a 196 ${ }^{\circ} \mathrm{C}$ negativo é maior do que se deformado à temperatura ambiente. Isso acontece devido ao aumento da densidade de discordância e ao aumento da quantidade das fases $\alpha$ ' e $\varepsilon$ formadas após deformação em baixas temperaturas. $O$ endurecimento dos AIAs é afetado não só com a formação de martensita a partir da estrutura CFC, mas também pelas bandas de deformação. Essas bandas de deformação são mais estáveis e podem resistir ao recozimento até $800{ }^{\circ} \mathrm{C}$ numa região não recristalizada. A fase $\varepsilon$ é estável até aproximadamente $200{ }^{\circ} \mathrm{C}$ e a martensita- $\alpha$ ' até $400{ }^{\circ} \mathrm{C}$. A quantidade de martensita induzida por deformação aumenta com a diminuição de temperatura [57]. A figura 16 ilustra a influência da temperatura na formação das martensitas metaestáveis $\varepsilon$ e $\alpha^{\prime}$ induzidas por deformação para uma certa taxa de deformação. A formação das fases $\varepsilon$ e $\alpha$ ' ocorre ao mesmo tempo e a diminuição da temperatura do teste de tração aumenta bruscamente a quantidade de martensita $\alpha$ '.

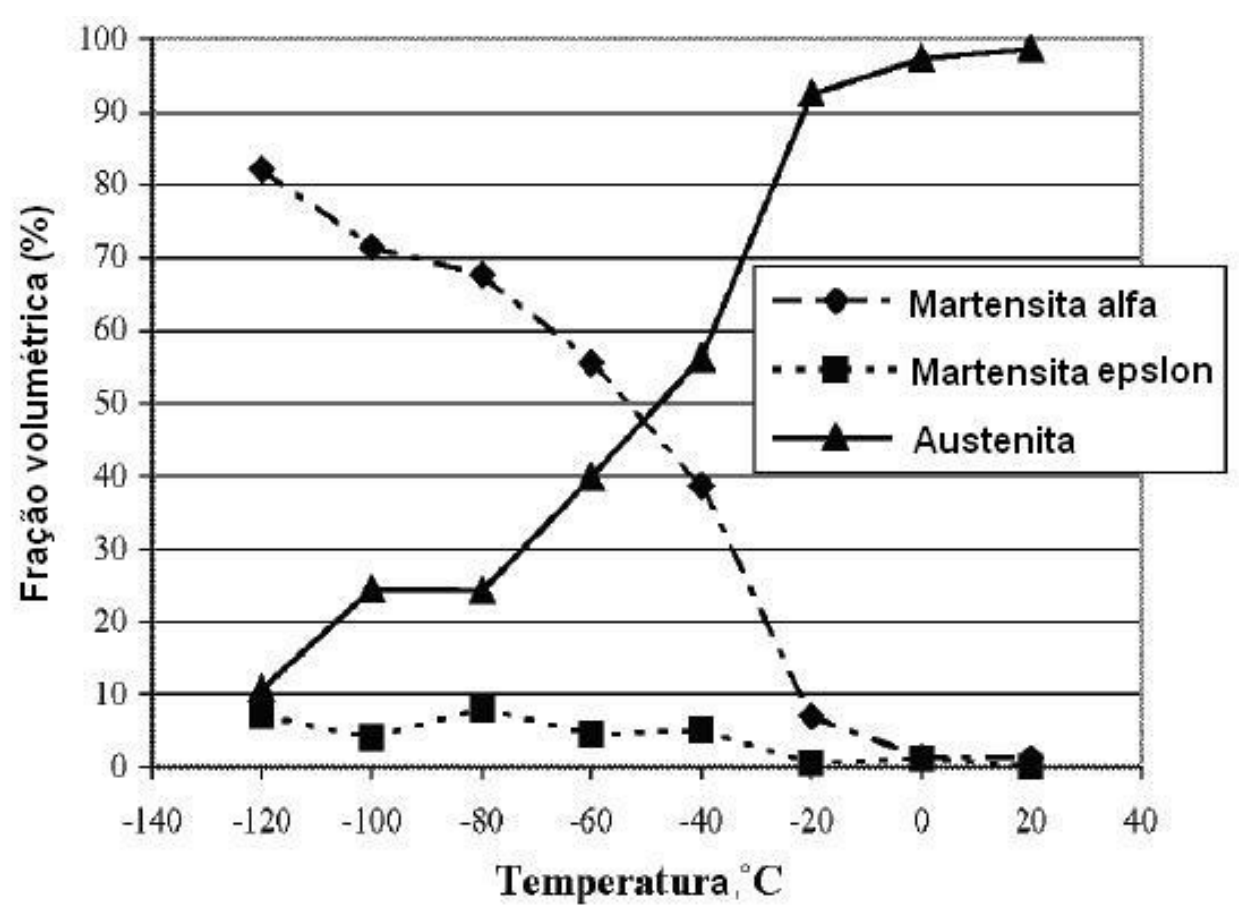

Figura 16 - Fração volumétrica das fases presentes em função da temperatura no aço KO36 (Fe$19 \% \mathrm{Cr}-10 \% \mathrm{Ni}$ ) [58].

Spencer e co-autores [59] verificaram o efeito da temperatura na formação da martensita induzida por deformação dos aços AISI 304L e 316L. Na temperatura 
ambiente, a taxa de encruamento decresce com a tensão aplicada; para temperaturas ainda menores como a $-196{ }^{\circ} \mathrm{C}$, o endurecimento dos aços aumenta significativamente com o aumento da tensão, em conseqüência da transformação martensítica. A martensita $\alpha$ funciona como um reforço da fase austenítica para suportar altos esforços sob cargas externas. A figura 17 mostra resultados de (um) ensaios de tração uniaxial. Quanto menor a temperatura do ensaio, maior será a tensão necessária para a mesma deformação do material [57]. Nagy e co-autores [58] também afirmam que a transformação $\varepsilon \rightarrow \alpha^{\prime}$ inicia em temperaturas acima de $80^{\circ} \mathrm{C}$.

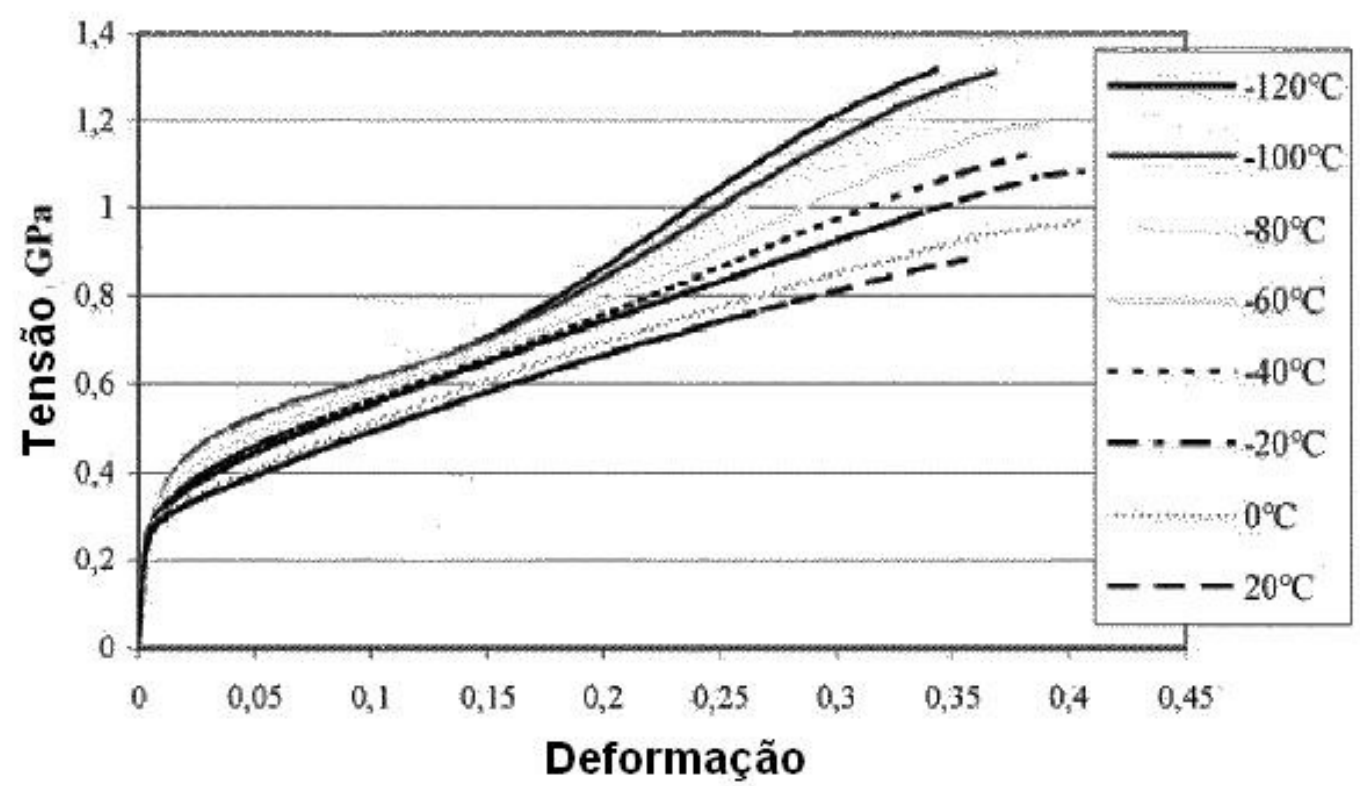

Figura 17 - Curva tensão x deformação de um AIA aço KO36 (Fe-19\%Cr-10\%Ni) realizado em diferentes temperaturas [58].

Fang e Dahl [36] afirmam que a deformação plástica em baixas temperaturas é favorável a melhoria da resistência mecânica dos AIAs. Uma vantagem de aplicação devido a este tipo de endurecimento da microestrutura é a possível economia de material, ou seja, a redução da espessura de parede em determinadas aplicações.

Tourki, Bargui e Sidhom [60] mostraram a evolução da martensita induzida por deformação do aço AISI 304 em função da temperatura, fixando a taxa de deformação em $10^{-3} / \mathrm{s}$. No passado, Angel [29] já havia realizado este mesmo tipo de investigação, havendo pequenas diferenças nas temperaturas selecionadas para os 
testes. A conclusão em ambos os trabalhos é a mesma e pode ser visto na figura 18: quanto mais baixas são as temperaturas, maiores são as quantidades formadas de martensita induzida por deformação.

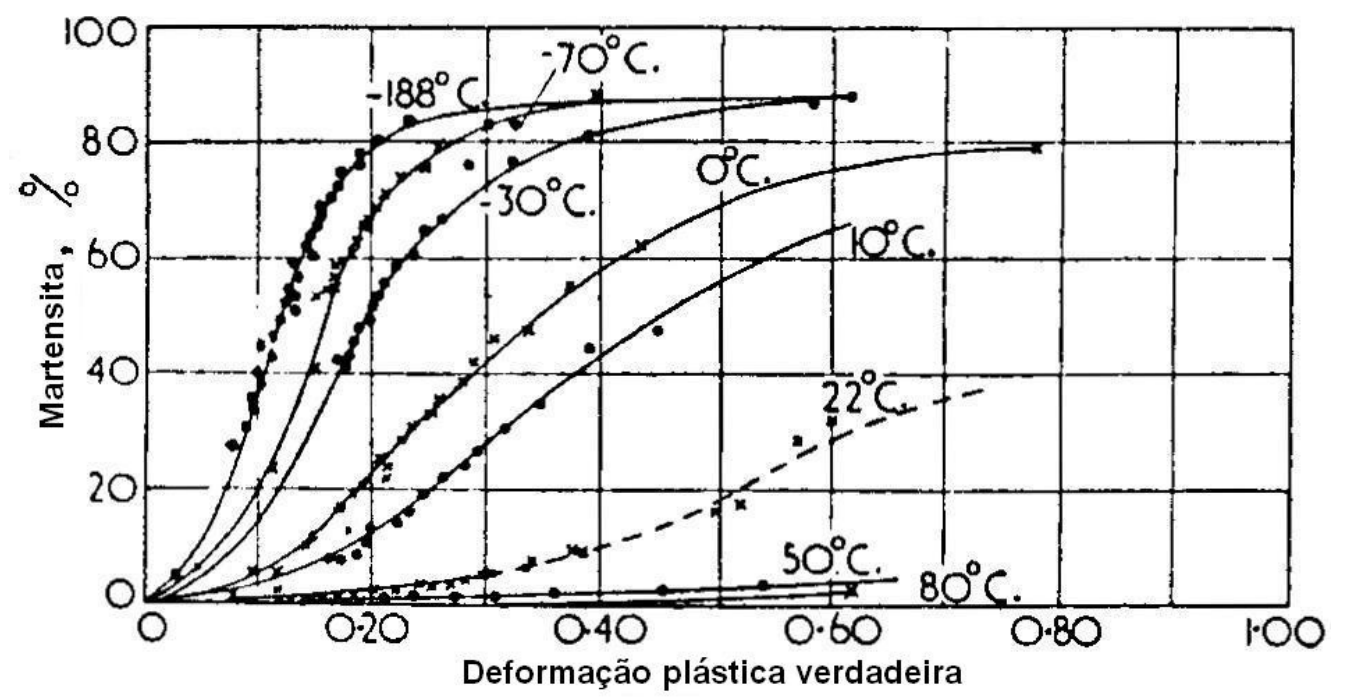

Figura 18 - Evolução da transformação martensítica induzida por deformação do aço AISI 304 para uma deformação de $10^{-3} / \mathrm{s}$ em função da temperatura [29].

Desta forma, pode-se concluir que a martensita induzida por deformação $\alpha$ ' tem grande influência do endurecimento dos AlAs e nas propriedades mecânicas convencionais, como limite de escoamento, limite de resistência, dureza e alongamento [60].

Byun, Hashimoto e Farrell [61] mostraram que os aços AISI 304 e AISI 316 recozidos e conformados a frio são fortemente dependentes da temperatura para alcançar resistência e ductilidade. A resistência aumenta com a diminuição da temperatura de deformação. Ao contrário da maioria dos metais, a ductilidade não é prejudicada sistematicamente com a diminuição da temperatura, obtendo valor máximo entre $-100{ }^{\circ} \mathrm{C}$ e a temperatura ambiente.

Lichtenfeld e co-autores [31] afirmam que além do efeito da temperatura imposta para a realização de um teste, há de se levar em conta quando o calor gerado pela deformação plástica é retido na amostra, ao invés de se dissipar. Este fato contribui para o aumento da temperatura durante a deformação plástica, favorecendo o aumento da estabilidade da austenita e menor quantidade de martensita induzida por deformação formada. 


\subsubsection{Efeito do grau de deformação}

Mangonon e Thomas [30] estudaram a transformação de fase induzida por deformação por meio de ensaio de tração a frio no aço AISI 304. A martensita $\varepsilon$ é formada no início da deformação atingindo seu pico com aproximadamente $5 \%$ de deformação. Aumentando a porcentagem de deformação, a quantidade da fase $\varepsilon$ presente diminui praticamente a zero para deformações próximas a $20 \%$ de redução [57]. A presença de martensita- $\alpha$ ' aumenta continuamente com o aumento da conformação, conforme mostra figura 19. Para elevados graus de redução, a martensita- $\alpha$ 'é a única fase presente, além da matriz austenítica.

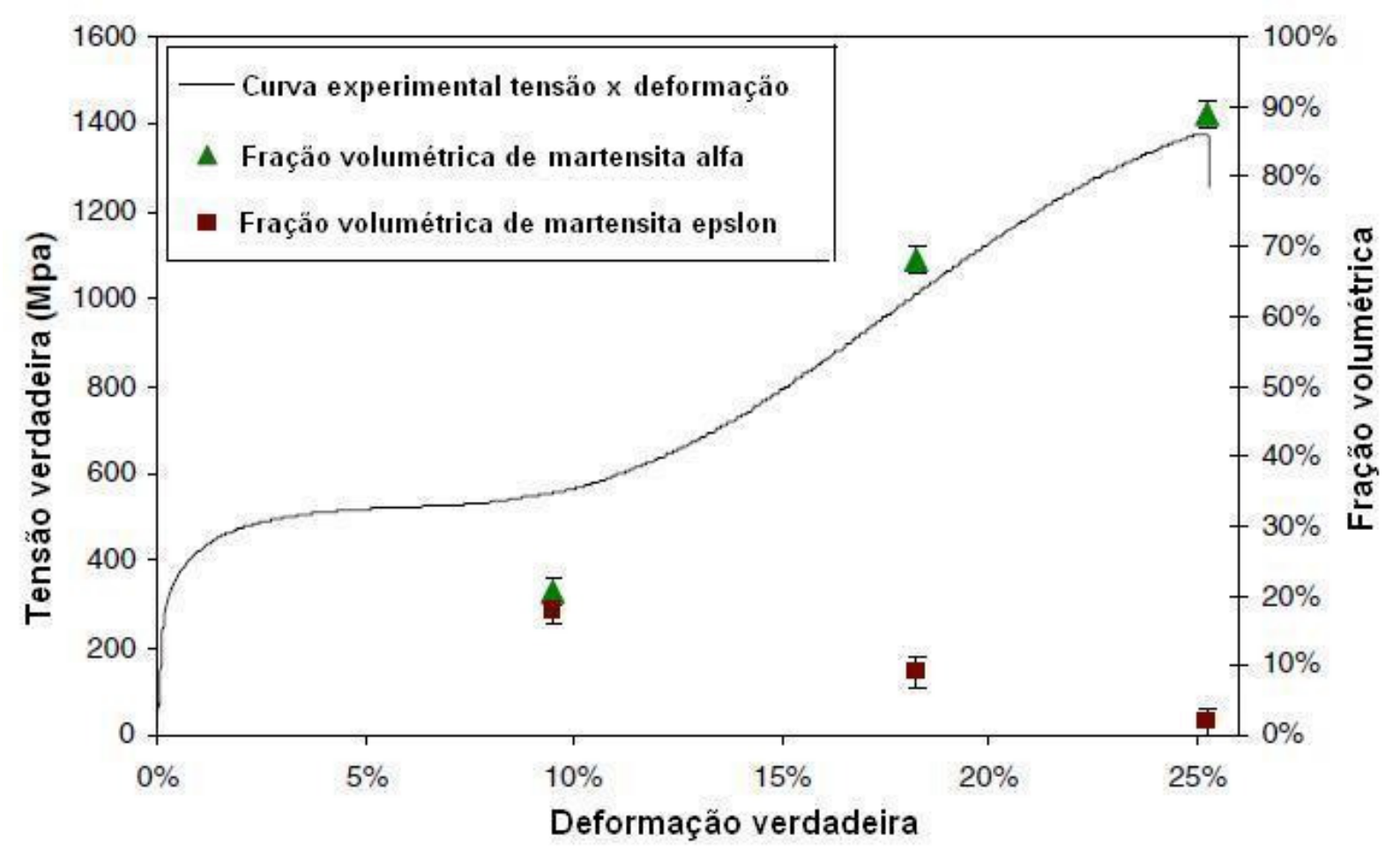

Figura 19 - Curva experimental tensão-deformação à temperatura de $-60^{\circ} \mathrm{C}$ e taxa de deformação de $10^{-4} \mathrm{~s}^{-1}$ do aço AISI 304 [50].

Como discutido anteriormente, a temperatura tem grande influência na transformação de fase induzida por deformação. Angel [29] verificou após numerosos ensaios de tração, a influência da temperatura combinada com diferentes graus de deformação. A figura 20 mostra que há uma mudança abrupta na estabilidade de austenita abaixo de certa temperatura; o efeito da deformação também fica evidente. Para baixas deformações, em torno de 0,10 , o formato da curva é significativamente diferente e tende a uma inclinação suave acima da qual 
não ocorre transformação. A quantidade de martensita formada é bem menor quando comparado a altas deformações para uma mesma temperatura de teste. As curvas $A, B$ e $C$ com maiores deformações apresentam um mesmo formato com mudança brusca da inclinação quando a temperatura fica logo abaixo da temperatura ambiente mostrando um aumento significativo da quantidade de martensita formada. Esta mudança de comportamento é justificada pela temperatura $M_{d}$ que para os aços AISI 304 está em torno de $20{ }^{\circ} \mathrm{C}$ [31].

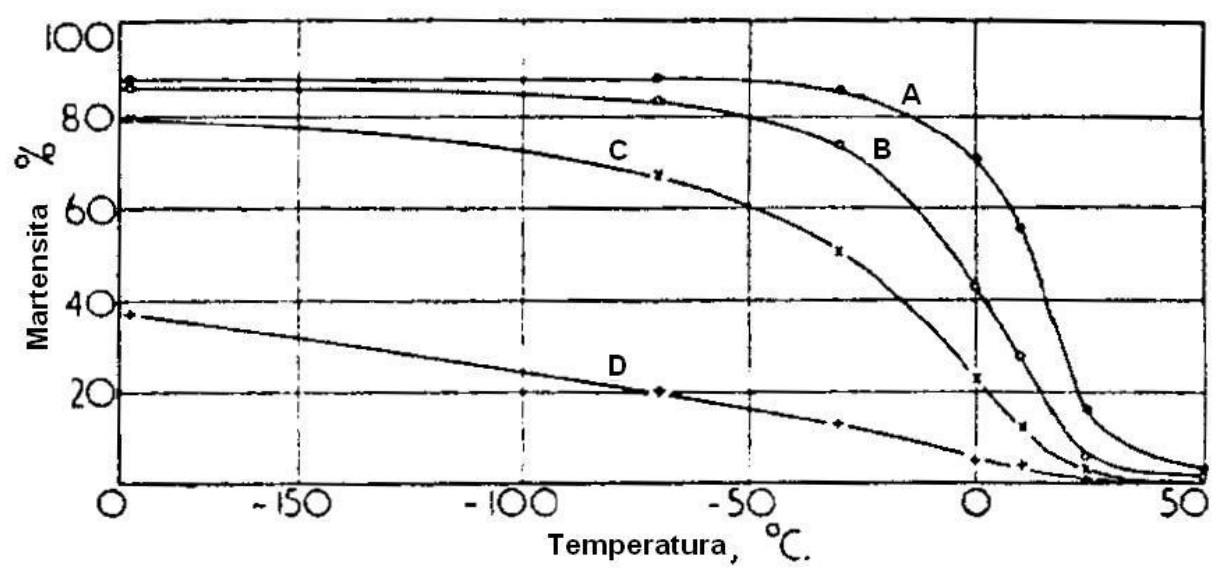

Figura 20 - Efeito da temperatura na formação da martensita em aço AISI 304 para as deformações verdadeiras (A) 0,50; (B) 0,30; (C) 0,20; (D) 0,10 [29].

Tavares e co-autores [39] publicaram recentemente um trabalho comparativo da influência do grau de deformação entre dois AIAs, o aço AISI 201 modificado (por conter cerca de 1,5\% em massa de cobre) e o AISI 304. A figura 21 mostra duas curvas comparativas do comportamento dos aços AISI 201 modificado e AISI 304. A taxa inicial de transformação martensítica (fração volumétrica) é maior nos aços AISI 304, mas se torna menor com o contínuo aumento da deformação. Isso acontece em conseqüência da menor EDE do(s) aço(s) AISI 201 modificado, em comparação ao aço AISI 304. O endurecimento dos aços também é diferente; a curva de microdureza em função da deformação verdadeira mostra que o aço AISI 201 modificado endurece mais quando comparado ao aço AISI 304 devido à adição de manganês em substituição ao níquel e também devido à maior susceptibilidade de transformação martensítica. Este foi o único trabalho [39] encontrado na literatura que estuda o efeito a transformação de fase induzida por deformação em aços da série 200 comparativamente a um aço da série 300 . Todas as outras referências utilizadas neste trabalho que compõe a revisão dos fatores que afetam 0 
endurecimento dos AIAs são referentes aos aços da série 300 .

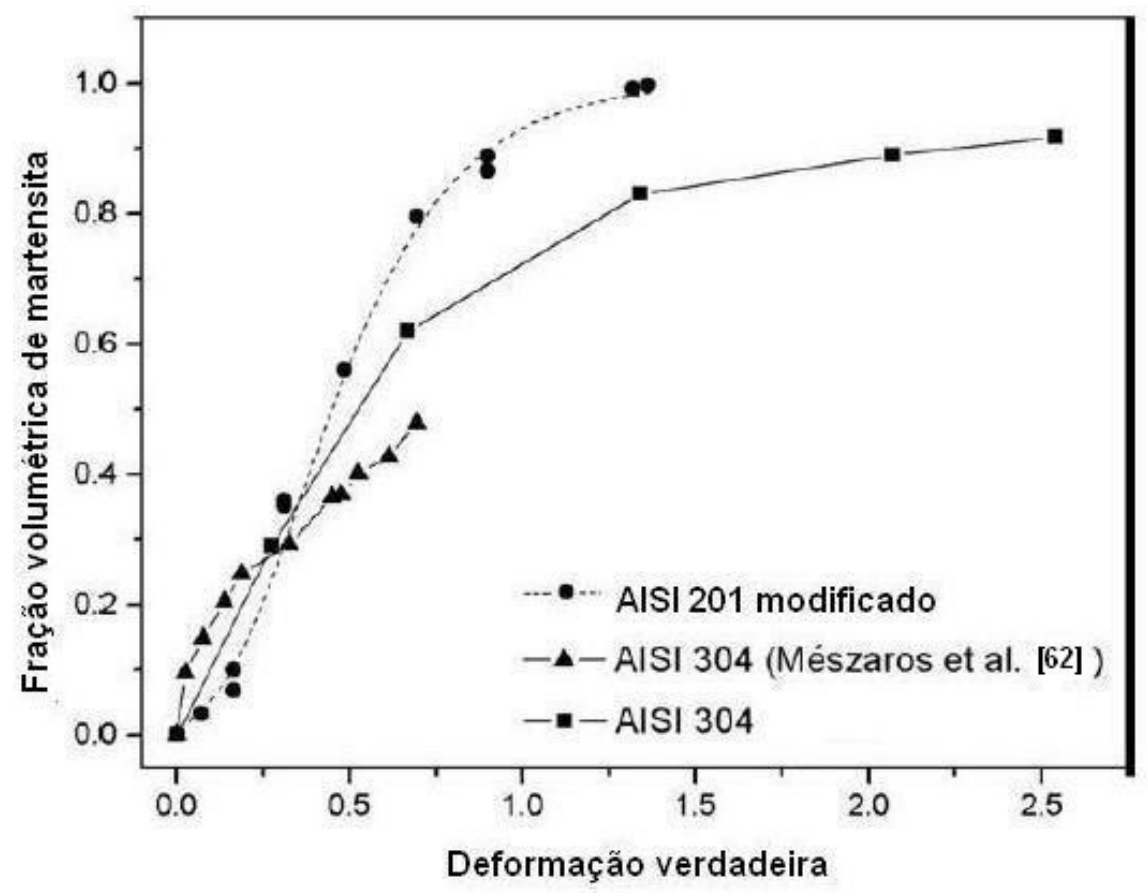

(a)

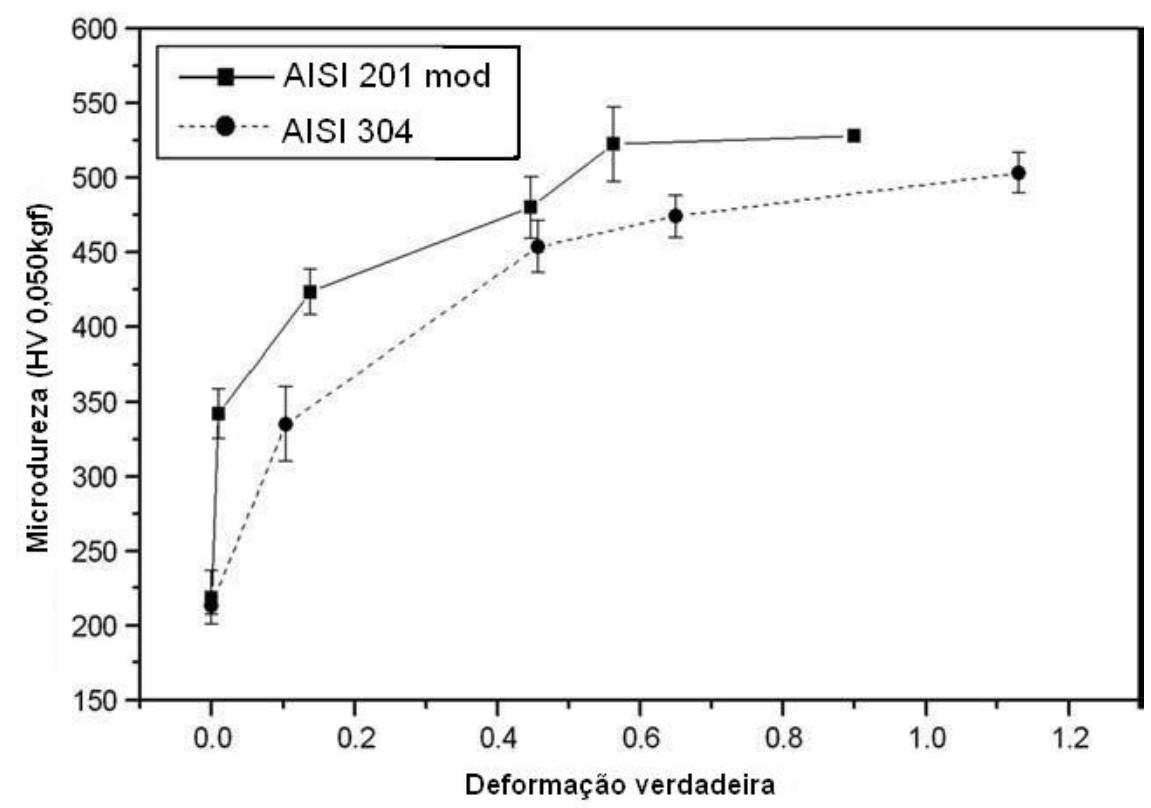

(b)

Figura 21 - Curva comparativa do comportamento dos aços AISI 201 modificado e AISI 304 (a) fração volumétrica de martensita induzida por deformação versus deformação verdadeira e (b) microdureza versus deformação verdadeira [39].

O limite de escoamento e a resistência à tração aumentam com a deformação a frio, enquanto a ductilidade diminui. Quanto maior o grau de deformação plástica, maior será a tensão necessária para deformar o metal [63]. Este fenômeno é 
conhecido como endurecimento por deformação. A causa para o endurecimento por deformação está relacionada ao aumento da dificuldade da movimentação das discordâncias, conforme o aumento da densidade de discordâncias com a deformação. Isso acontece devido à interação entre as discordâncias ou com os interstícios e outros defeitos cristalinos [48]. Certos elementos aumentam a taxa de endurecimento por deformação dos AIAs. As séries com baixo teor de níquel, como a série 200 , são menos estáveis e tenderão gradualmente a transformação de martensita induzida por deformação a frio, apresentando maior endurecimento quando comparados a AIAs contendo maior teor de níquel, conforme indica figura 22.

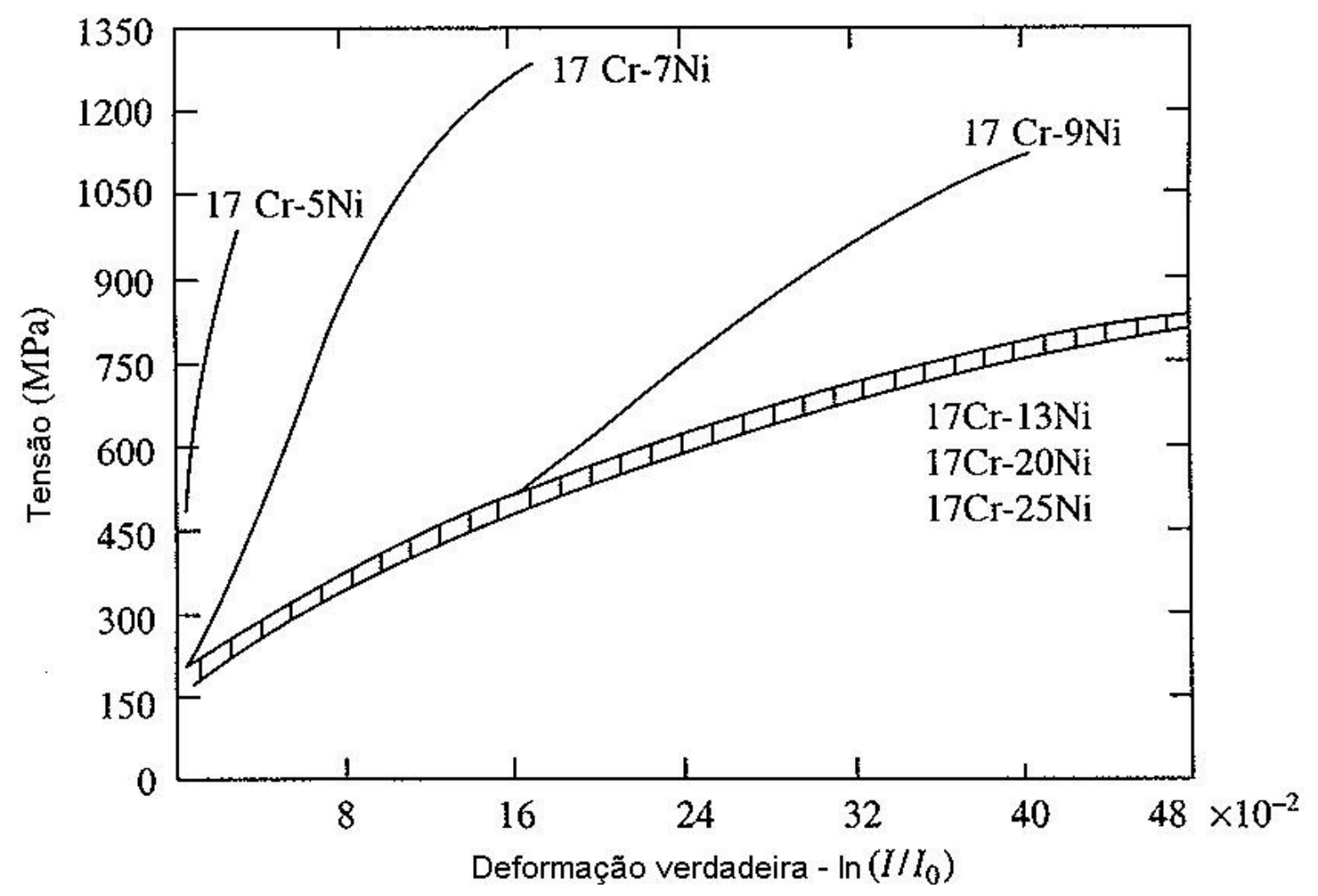

Figura 22 - Efeito do teor de níquel na curva tensão-deformação para AIAs com 17\% de cromo [48].

Recentemente, Hedayati e co-autores [64] publicaram um estudo sobre o efeito da laminação a frio na microestrutura e propriedades mecânicas do aço AISI 304L. Pequenos pedaços de chapas deste aço foram laminados em diversos passos com uso de lubrificação para atingir diferentes reduções de 10 a 90\%, fixando a taxa de deformação em $2,1 \times 10^{-3} \mathrm{~s}^{-1}$ a $0{ }^{\circ} \mathrm{C}$. O padrão de identificação de fases obtido por análise de difração de raios $X$ (DRX, a partir da amostra solubilizada $(0 \%$ de 
redução) até a última amostra reduzida a 90\% pode ser vista na figura 23.

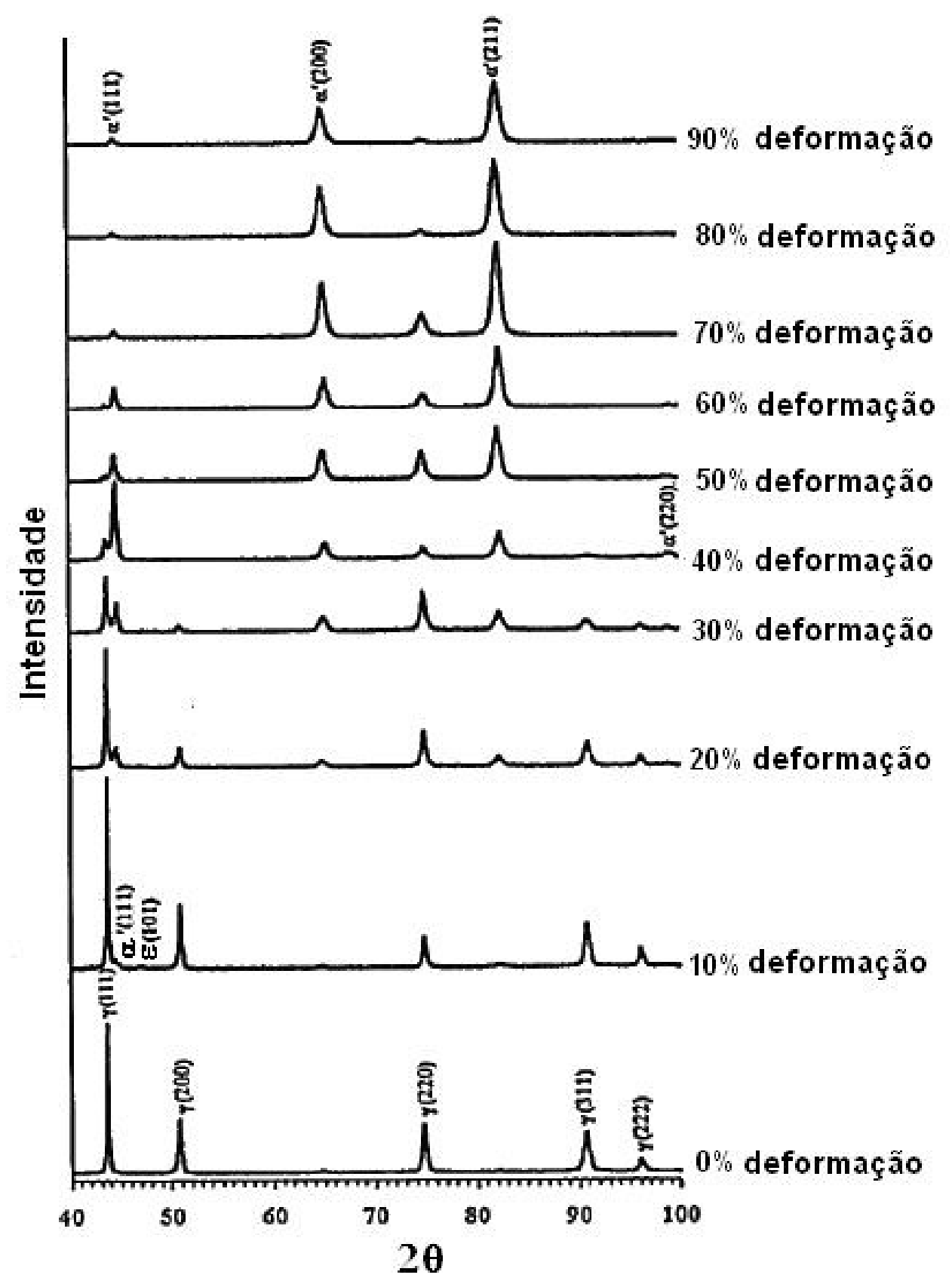

Figura 23 - DRX de tiras do aço AISI 304L laminadas a frio a $0{ }^{\circ} \mathrm{C}$ [64].

A análise de DRX identificou que a amostra solubilizada (antes da laminação) era totalmente austenítica. Apesar da difícil identificação dos picos de martensita $\varepsilon$, um fraco sinal foi observado na amostra laminada a $10 \%$ de redução. Com o aumento da redução durante a laminação a frio, a intensidade dos picos de austenita gradualmente diminuiu, enquanto os picos de martensita foram identificados e sua intensidade aumentou. Em deformações severas, próxima de 90\%, a microestrutura 
é composta totalmente por martensita- $\alpha$. Para deformações de $70 \%, 95 \%$ da austenita já haviam sido transformadas em martensita- $\alpha$ '. A análise de DRX comprovou que a transformação de fase da austenita metaestável para martensita foi induzida por deformação [64].

\subsubsection{Efeito da taxa de deformação}

A taxa cuja deformação é aplicada a um material pode ter influência direta na tensão [63]. A taxa de deformação é definida pela equação $\varepsilon=d \varepsilon / d t$ e é convencionalmente expressa na unidade "por segundo" ou [s $\left.{ }^{-1}\right]$. Em geral, as faixas da taxa de deformação usualmente adotadas em diferentes ensaios estão expressas na tabela 6.

Tabela 6 - Faixas de trabalho da taxa de deformação [63].

\begin{tabular}{cl}
\hline $\begin{array}{c}\text { Faixas de trabalho da taxa de } \\
\text { deformação }\end{array}$ & \multicolumn{1}{c}{ Condição ou tipo de teste } \\
\hline $10^{-8}$ a $10^{-5} \mathrm{~s}^{-1}$ & Teste de fluência a cargas ou tensões constantes \\
$10^{-5}$ a $10^{-1} \mathrm{~s}^{-1}$ & Teste de tensão "estática“ com máquina hidráulica \\
$10^{-1}$ a $10^{2} \mathrm{~s}^{-1}$ & Testes de compressão ou tensão dinâmicos \\
$10^{2}$ a $10^{4} \mathrm{~s}^{-1}$ & Teste de alta velocidade como ensaio de impacto \\
$10^{4}$ a $10^{8} \mathrm{~s}^{-1}$ & Teste de impacto de ultra-velocidade (Propagação \\
& de ondas por choque) \\
\hline
\end{tabular}

O aumento da taxa de deformação induz o aumento do endurecimento mais rapidamente, o que leva ao consequente aumento da resistência à tração [63], conforme mostra a figura 24 . 


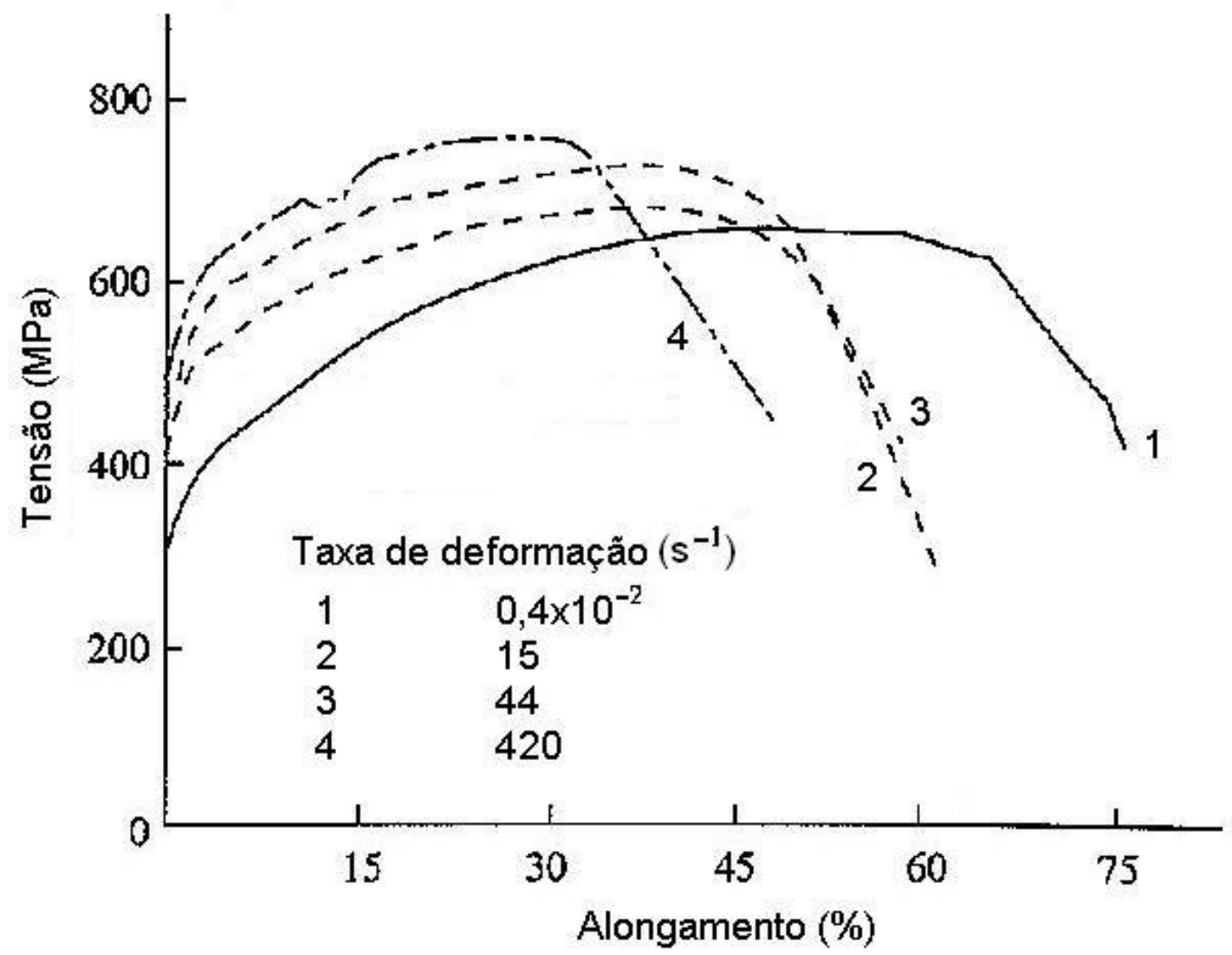

Figura 24 - Curva tensão-deformação de um AIA 18\%Cr-12\%Ni-2\%Mo deformado em diferentes taxas de deformação à temperatura de $20^{\circ} \mathrm{C}$ [48].

Uma série de relações foram propostas para associar a tensão e a deformação em metais durante a deformação plástica [65]. A dependência da deformação muitas vezes segue uma de muitas formas de cálculo, como as propostas por Hollomon e Voce [65]:

Hollomon: $\quad \sigma_{1}=\mathrm{K}^{*} \varepsilon^{\mathrm{n}}$

Voce: $\quad \sigma_{1}=\sigma_{0}+\sigma_{\mathrm{s}}\left[1-\exp \left(-\varepsilon_{1} / \varepsilon_{0}\right)\right]$

$\mathrm{Na}$ equação de Hollomon, os valores de $\mathrm{K}$ e $\mathrm{n}$ são constantes para cada material, denominados coeficiente de resistência e coeficiente de encruamento, respectivamente [66]. $\varepsilon_{0}$ e $\varepsilon_{s}$ são constantes que podem variar conforme 0 tratamento a que o material foi submetido. $O$ expoente de encruamento por deformação na equação de Hollomon, n, é um parâmetro importante que indica o grau de encruamento dos metais, ou seja, mede sua capacidade de endurecimento por meio de ensaio de tração [66]. 
As propriedades mecânicas dos AIAs deformados a taxas moderadamente altas tem sido de grande interesse em explicar e prever o comportamento do material durante o processo de deformação [31]. Mais recentemente, os AIAs tem sido considerados para o desenvolvimento de estruturas resistente ao impacto para componentes automobilísticos devido a sua boa capacidade de absorção de energia associada a boa propriedade de conformabilidade [31].

Talonen e co-autores [47] estudaram o efeito da taxa de deformação nas propriedades de resistência e na transformação da austenita em martensita- $\alpha$ ' para os aços AISI 301LN e 304 para as faixas de $3 \times 10^{-4}$ a $200 \mathrm{~s}^{-1}$. A conclusão foi que a transformação de fase induzida por deformação é altamente dependente do aquecimento adiabático, que afeta diretamente a taxa de encruamento e o limite de resistência. Os AIAs que Talonen e co-autores [47] estudaram, mostraram significativa diferença de comportamento para altas taxas de deformação, quando comparados a teste quase-estático (ou taxas de deformação muito baixas). A mudança no comportamento das propriedades mecânicas deve-se ao aumento da taxa de deformação depender diretamente da estabilidade da austenita.

Quase um ano depois, Lichtenfeld e co-autores [31] fizeram um trabalho com mesmo propósito que o de Talonen e co-autores [47], porém selecionando AIAs mais estáveis. No trabalho, os autores [31] buscaram investigar o efeito da taxa de deformação na evolução das propriedades mecânicas e na transformação de fase induzida por deformação em temperatura ambiente para os aços AISI 304L e 309. A estabilidade da austenita desses dois materiais contrasta com os materiais estudados por Talonen e co-autores [47]. No trabalho de Lichtenfeld e co-autores foi estabelecida uma faixa de taxa de deformação a ser estudada, de $1,25 \times 10^{-4} \mathrm{~s}^{-1}$ a 400 $\mathrm{s}^{-1}$. O limite de escoamento de ambos os aços aumentou com o aumento da taxa de deformação.

De maneira geral, o efeito da taxa de deformação é difícil de ser avaliada isoladamente porque, conforme a taxa de deformação aumenta, a temperatura do corpo de prova também aumenta devido ao aquecimento Joule [16].

\subsubsection{Efeito do modo de deformação}

Na literatura, há informação sobre o estudo da transformação de fase de AIAs 
metaestáveis por meio de diferentes modos de deformação, dentre eles, ensaio de tração $[29,30,31,67,68]$ laminação a frio $[41,69,70]$ e ensaio de torção a alta pressão (HPT) [71]. O único trabalho encontrado [57] que comparou o efeito do modo de deformação (ensaios de laminação a frio e ensaio de tração) na formação da martensita induzida por deformação, mostra, na figura 25 , que as frações volumétricas de $\varepsilon$ e $\alpha$ ' variam com o grau de deformação.

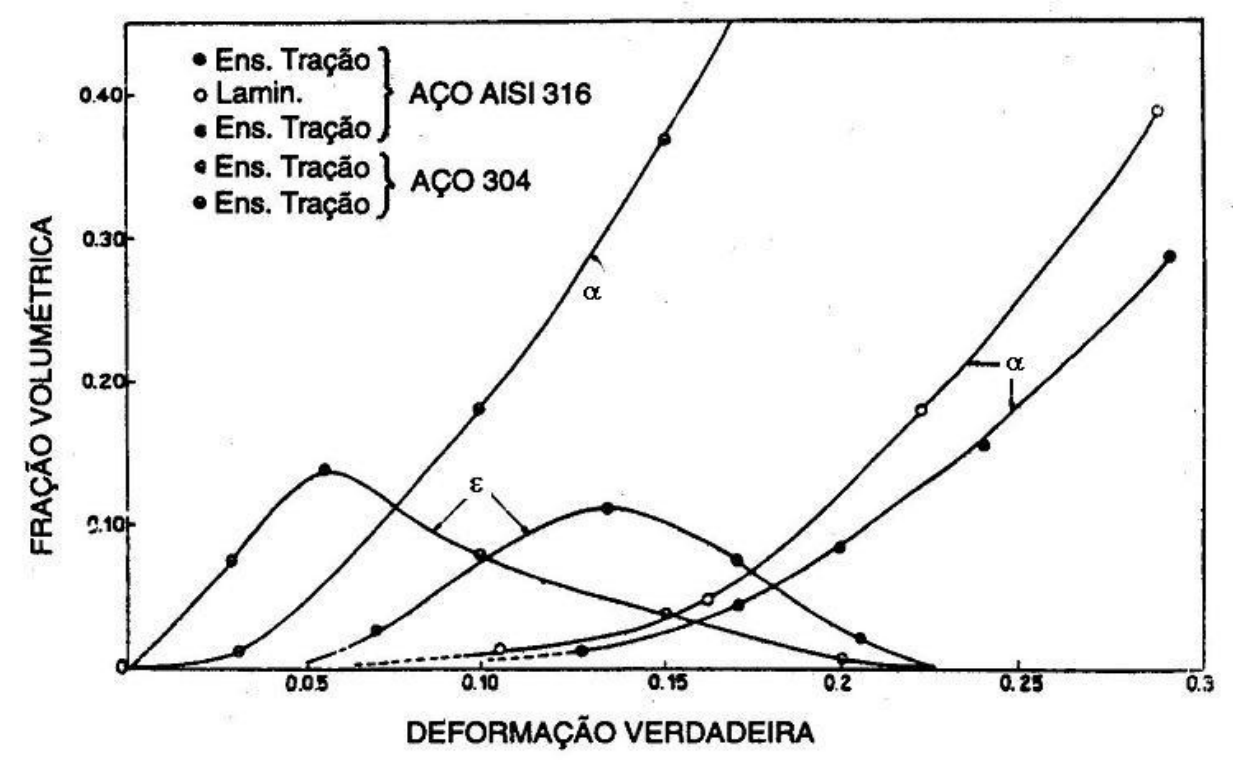

Figura 25 - Variação das quantidades de martensita $\alpha^{\prime}$ e $\varepsilon$ com o grau de deformação para os aços AISI 304 e AISI 316 [57].

Como já foi discutido anteriormente, a martensita $\varepsilon$ é formada apenas no estágio inicial da deformação, seja por laminação ou ensaio de tração a frio [30]. Há evidências de que a martensita $\varepsilon$ desaparece quando os AIAs são deformados em altas taxas. No entanto, a junção de fatores como a tensão de cisalhamento, a elevada pressão e a temperatura gerada pela conformação exercida no ensaio de HPT promovem a formação de martensita $\varepsilon$ em aços AISI 304 através da seqüência de reação $\alpha$ ' $\rightarrow \varepsilon$ para elevados graus de deformação [71].

Padilha e Guedes [57] mencionam que durante o ensaio de tração ocorre um gradiente de deformação e um gradiente de velocidade de deformação ao longo do corpo de prova, causando um considerável gradiente de temperatura. A quantidade de martensita- $\alpha$ ' formada em ensaio de tração aumenta com o aumento de deformação, porém pode ser suprimida por pressão hidrostática. A pressão 
hidrostática abaixa a temperatura $M_{s}$, além de modificar sensivelmente a curva tensão versus deformação. Espera-se que a pressão hidrostática dificulte a formação da fase $\alpha^{\prime}$, uma vez que a transformação $\gamma \rightarrow \alpha^{\prime}$ gera expansão volumétrica. Da mesma forma, a pressão hidrostática interfere na reação $\gamma \rightarrow \varepsilon$, porém facilita a transformação, uma vez que há contração de volume. Isso sugere que diferentes processos de deformação formam diferentes frações de martensita para o mesmo grau de deformação. Não há dados adicionais na literatura sobre esta discussão.

Em AIAs metaestáveis que são deformados por baixa velocidade de deformação, a microestrutura tende a ter distribuição planar de discordâncias e presença de martensita $\alpha$ ' nas intersecções entre planos de escorregamento. Já em AlAs que passaram por alta velocidade de deformação tendem a formar sub-grãos ou arranjo celular [57].

Recentemente, Milad e co-autores [72] estudaram o efeito da deformação a frio na estrutura e propriedades de AIA AISI 304 após a laminação a frio. Amostras laminadas em diferentes reduções até $50 \%$ foram posteriormente tracionadas. Os limites de escoamento e de resistência do aço investigado aumentaram gradualmente na mesma taxa que a porcentagem da redução na laminação aumentou. 


\subsection{Martensita induzida por deformação}

Dependendo da composição e variáveis de processo a que os AlAs foram submetidos, a deformação plástica pode causar a formação de martensita induzida por deformação. A transformação da austenita para martensita em baixas temperaturas ocorre por processo de cisalhamento, sem haver difusão [62].

Dois tipos de martensita podem ser formados nos AIAs, a martensita- $\varepsilon$ e martensita- $\alpha$ '. Suas principais características $[62,73]$ estão descritas na tabela 7 a seguir:

Tabela 7 - Principais características dos dois tipos de martensita induzida por deformação

\begin{tabular}{ccccc}
\hline Martensita & Austenita $-\gamma$ & Martensita $-\varepsilon$ & Martensita - $\alpha^{\prime}$ \\
Parâmetro de rede & $\mathrm{A}=0,3588 \mathrm{~nm}$ & $\begin{array}{c}\text { Cúbica de face } \\
\text { centrada }(\mathrm{CFC}) \\
\text { Propriedade } \\
\text { magnética }\end{array}$ & $\begin{array}{c}\text { Hexagonal compacta } \\
(\mathrm{HC})\end{array}$ & $\begin{array}{c}\text { Cúbica de corpo } \\
\text { centrada }(\mathrm{CCC})\end{array}$ \\
Paramagnética & Paramagnética & Ferromagnética \\
\hline
\end{tabular}

Avaliando os valores de parâmetro de rede das fases martensita $\varepsilon$ e $\alpha$, pode haver mudança volumétrica se comparado ao da austenita $\left(a_{\gamma}=0,3588 \pm 0,0002 \mathrm{~nm}\right)$. A transformação $\gamma \rightarrow \alpha$ induz uma expansão volumétrica de $2,57 \%$, enquanto na transformação $\gamma \rightarrow \varepsilon$ haverá contração de $1,12 \%$ [74]. As fases $\varepsilon$ e $\alpha$ são metaestáveis e podem ser revertidas a austenita se aquecidas à temperatura abaixo da temperatura de recristalização.

A formação de martensita induzida por deformação é uma característica única dos AlAs [27], além de aumentar significativamente as propriedades mecânicas dos aços conformados a frio, conforme indicado na figura 26. O alto encruamento dos AIAs é causado pela baixa EDE desses materiais. As transformações martensíticas 
$\gamma \rightarrow \varepsilon$ e $\gamma \rightarrow \alpha$ ' são favorecidas pela baixa EDE [39].

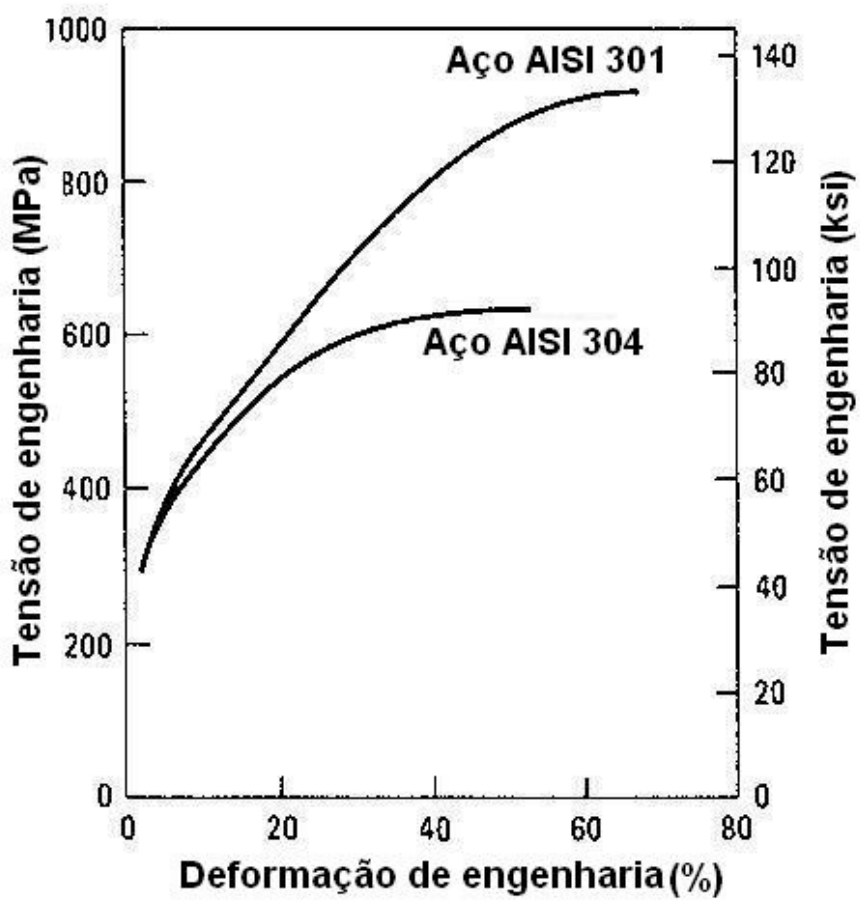

Figura 26 - Curva típica tensão-deformação dos aços inoxidáveis austeníticos AISI 301 e 304 [27].

Após certo nível de deformação, a transformação martensítica induzida ocorre aumentando significativamente as propriedades mecânicas e também a susceptibilidade magnética [30], como ilustrado na figura 27.

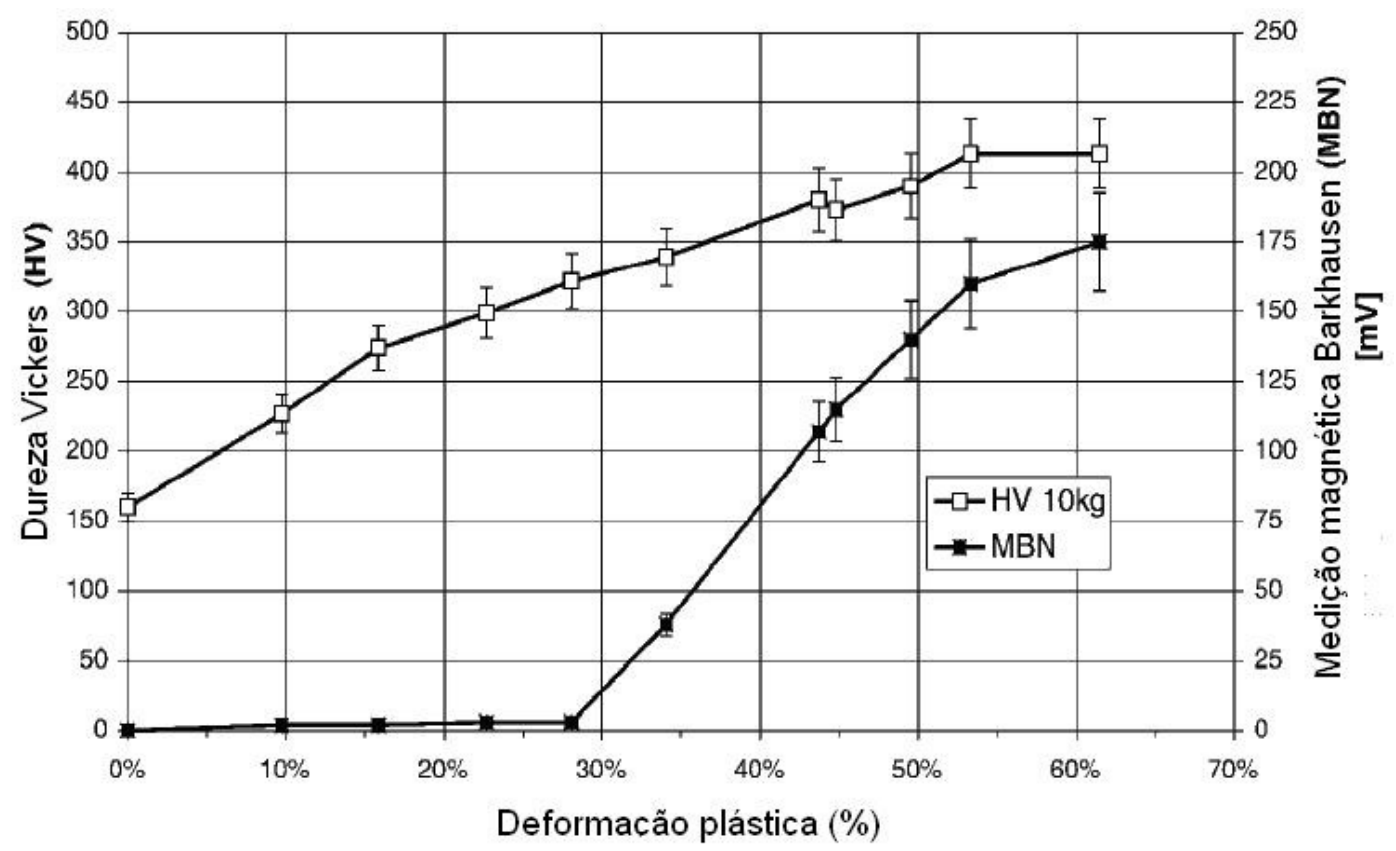

Figura 27 - Efeito da deformação nas propriedades magnéticas e dureza do aço AISI 304 [62]. 
A ocorrência e a quantidade de martensita- $\varepsilon$ e martensita- $\alpha$ ' dependem de uma série de fatores como a composição do aço, a energia de defeito de empilhamento, a temperatura, o grau, a taxa e modo de deformação [74], que já foram discutidos neste trabalho.

Mangonon e Thomas [69] estabeleceram que a transformação martensítica induzida por deformação em AIAs metaestáveis AISI 304 (18\%Cr-8\%Ni) é formada pela seqüência $\gamma \rightarrow \varepsilon \rightarrow \alpha$ e não pela $\gamma \rightarrow \alpha$ ' com $\varepsilon$ resultando da deformação por cisalhamento. Esta afirmação é baseada em evidências que $\varepsilon$ se forma independente e anteriormente a fase $\alpha$, e também por ter sido observada dentro de $\alpha$ '. A fase $\alpha$ ' nucleia preferencialmente na intersecção de duas bandas na fase $\varepsilon$ ou onde há junção de fase $\varepsilon$ com um contorno de grão ou macla que representa regiões de compressão unilateriais. A fase $\varepsilon$ é termodinamicamente mais estável quando comparadas as fase $\gamma$ e $\alpha^{\prime}$ [69]. O tamanho de $\alpha^{\prime}$ é limitado pelo de $\varepsilon$.

Após trabalharem com o AIA estável AISI 316, Seetharaman e Krishnan [75] também verificaram que, durante deformação em temperaturas baixas, a formação de martensita $\varepsilon$ precedia a formação de martensita- $\alpha$. Em seu trabalho, Seetharaman e Krishnan [75] sugeriram a mesma seqüência de transformação que Mangonon e Thomas [69]: $\gamma \rightarrow \varepsilon \rightarrow \alpha^{\prime}$. A martensita- $\varepsilon$ é gerada a partir da austenita e é transformada em martensita- $\alpha$ '. Segundo Seetharaman e Krishnan [75], a martensita $\alpha$ ' também pode ser formada diretamente a partir da austenita.

Brooks, Loretto e Smallman [76] constataram por meio de experiências em microscópio eletrônico de alta voltagem que o núcleo de martensita- $\varepsilon$ se forma a partir do acúmulo de defeitos de empilhamento causado pela deformação, enquanto a martensita- $\alpha$ ' nucleia a partir do empilhamento de discordâncias de regiões com defeito cristalino. A nucleação inicia nos defeitos cristalinos cujas estruturas atômicas apresentam mais próximas da martensita. Este mecanismo de nucleação é adequado aos AIAs metaestáveis de baixa EDE que apresentam a seqüência de transformação $\gamma \rightarrow \varepsilon \rightarrow \alpha$. Não se sabe se este mecanismo pode ser aplicado aos aços de elevada EDE, cujo produto da transformação induzida por deformação é apenas a martensita- $\alpha$ '.

Muitos trabalhos [76-80] afirmam que a martensita formada em AlAs do sistema Fe-Cr-Ni, seja por resfriamento ou por deformação plástica, é similar à dos aços que possuem $M_{s}$ acima da temperatura ambiente e são relacionadas a 
austenita pela relação Kurdjumov-Sachs (K-S). Adicionalmente, Bowkett, Keown e Harries [68] discutem que a relação de orientação entre a austenita $\gamma$ e a martensita $\alpha$ ' tem evidência para ambas as relações Kurdjumov-Sachs (K-S) e NishiyamaWassermann (N-W).

O elemento níquel dos AIAs pode ser substituído por manganês, porém a solução sólida de Fe-Cr-Mn possui energia de defeito de empilhamento menor que a do sistema Fe-Cr-Ni. Isto significa que a solução sólida CFC é energeticamente mais próxima de uma estrutura hexagonal compacta $(\mathrm{HC})$ e que as discordâncias no sistema Fe-Cr-Mn tenderão a dissociar-se para formar defeitos de empilhamentos maiores do que os encontrados na austenita do sistema Fe-Cr-Ni. Desta forma, a fase formada inicialmente é a martensita- $\varepsilon$, que possui estrutura hexagonal, com plano de hábito $\{0001\}_{\varepsilon}$, paralelo ao plano de defeito de empilhamento $\{111\}_{\gamma}$. Estas fases nucleiam nos defeitos de empilhamento com a seguinte orientação em relação à austenita [73]:

$$
\begin{aligned}
& \{111\}_{\gamma} / /\{0002\}_{\varepsilon} / /\{011\}_{\alpha}, \\
& <110>_{\gamma} / /<1120>_{\varepsilon} / /<111>_{\alpha},
\end{aligned}
$$

Este tipo de martensita possui morfologia de agulha que pode ser facilmente confundido com maclas de recozimento, muito comuns em materiais CFC com baixa EDE. Em geral, a martensita $\alpha$ ' forma-se a partir da nucleação na interface entre a martensita $\varepsilon$ e a matriz austenita. É de extrema importância utilizar os equipamentos de caracterização mais indicados para este tipo de análise.

Em geral, os metais CFC exibem maiores taxas de encruamento do que os metais CCC, devido às interações de discordâncias mais estáveis na estrutura CFC.

\subsubsection{Principais técnicas de avaliação da martensita induzida por deformação}

A medição da fração volumétrica de martensita- $\alpha$ ' induzida por deformação formada em AlAs pode ser quantificada por meio de uma série de técnicas de avaliação. As técnicas mais utilizadas descritas na literatura serão discutidas a seguir:

- Medidas magnéticas [64,72,81-83]: o ferritoscópio tem como princípio de 
funcionamento a aplicação de um campo magnético para determinar a quantidade de fase ferromagnética contida na amostra. O campo magnético é gerado por uma resistência que interage com os componentes magnéticos presentes na amostra a ser avaliada. A mudança no campo magnético gera uma voltagem numa resistência secundária, proporcional à quantidade de fase ferromagnética da amostra. Todos os componentes magnéticos da matriz são reconhecidos, dentre eles ferrita $\delta$ e ou martensita $\alpha$ '. O principio de funcionamento está esquematizado na figura 28 a seguir. O resultado obtido é dado em porcentagem de fase ferromagnética presente no material. Esta será a técnica adotada neste trabalho para quantificar a presença de fase ferromagnética.

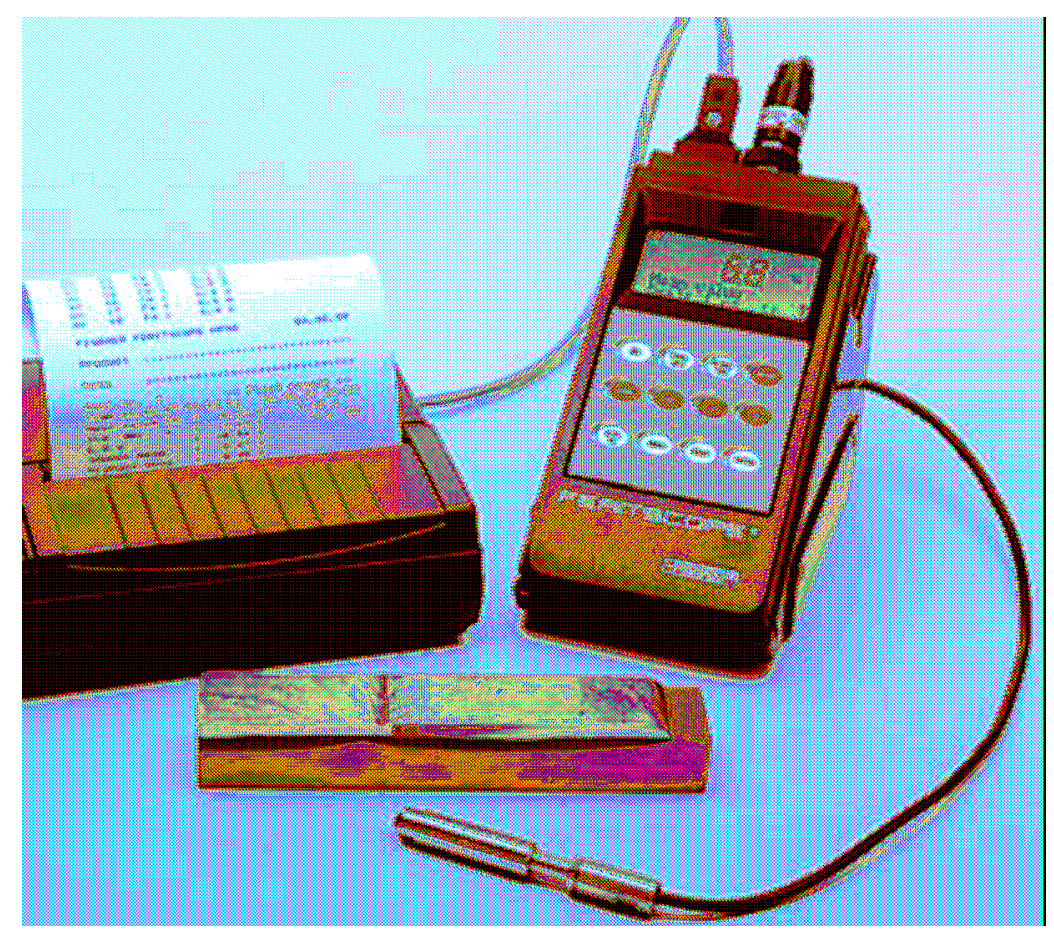

Figura 28 - Ferritoscópio Fisher modelo MP30E [82].

- Medidas de resistividade elétrica [84]: O perfil de resistividade é determinado pelo balanço da quantidade de martensita formada e a quantidade de defeitos induzido pela deformação;

- Análise por difração de raios $X$ (DRX) [41, 71, 85]: com auxílio de um difratômetro e radiação monocromática, as posições e as intensidades dos picos de difração de uma amostra são medidas. Para identificação de fase, a análise utiliza a Lei de Bragg. O limite de detecção da análise de DRX é cerca 
de 5\%. Para baixos graus de deformação, ou seja, para análise de AIA com quantidade de martensita inferior a 5\%, a análise de DRX não é indicada [85]. Esta técnica também será utilizada neste trabalho.

- Medição de saturação magnética [41,47,70,78]: A fração volumétrica da martensita induzida por deformação formada pode ser calculada indiretamente a partir da medição de saturação magnética $\left(m_{s}\right)$. A equação para o cálculo da fração volumétrica de martensita (C $\left.\alpha^{\prime}\right)$ [39] é dada a seguir. A figura 29 indica um gráfico resultante desta medição.

$$
\mathrm{C} \alpha^{\prime}=\mathrm{m}_{\mathrm{s}} / 140
$$

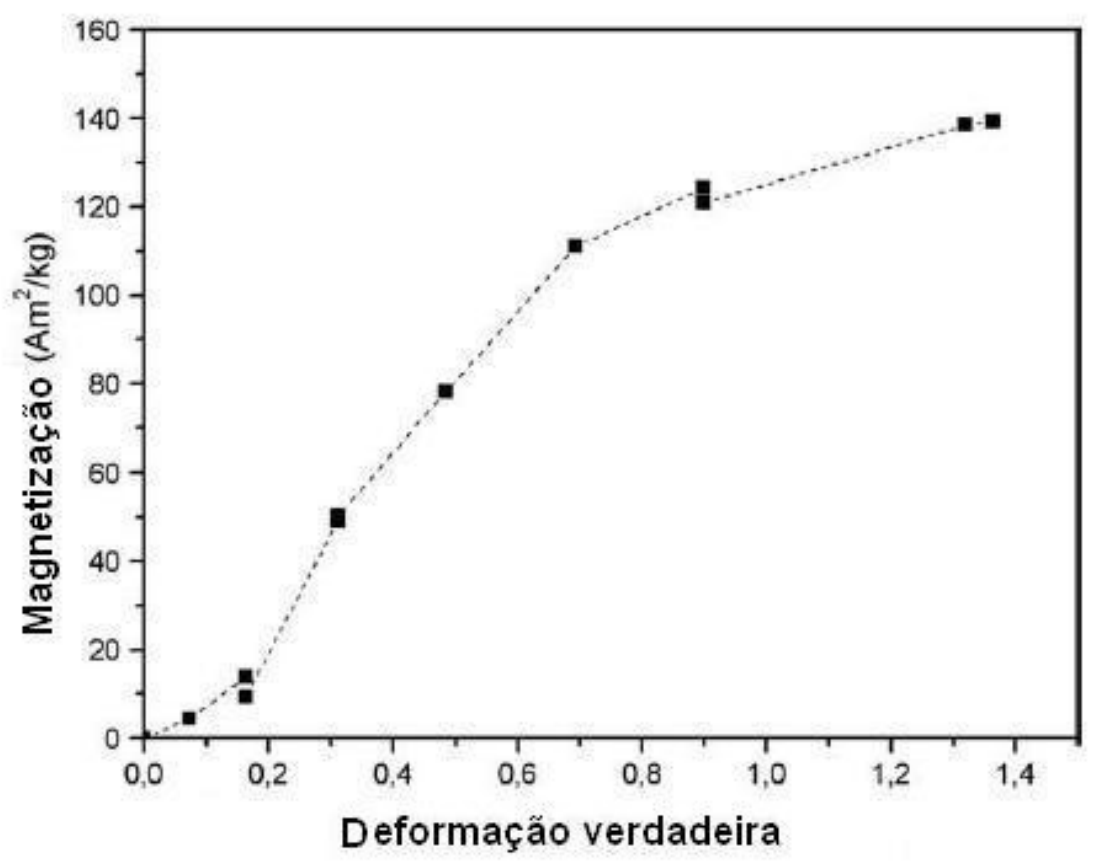

Figura 29 - Saturação magnética em função da deformação verdadeira de um aço AISI 201 modificado [32].

- Análise térmica: devido à energia armazenada na deformação ser muito baixa em comparação com outras transformações de fase, algumas técnicas de análise térmica como termopar tornam-se inviáveis [86]. É cada vez mais comum o uso de calorimetria exploratória diferencial (DSC), mais sensível que a análise térmica diferencial, nos estudos da transformação de fase em AIA. Um resultado típico obtido por esta técnica pode ser visto na figura 30, a seguir. Esta técnica utiliza a modulação senoidal da rampa de aquecimento e o sistema separa as componentes reversíveis e irreversíveis dos calores 
envolvidos nas reações [87]. Outra técnica também utilizada para observação da transformação de fase induzida pela deformação é a análise térmica diferencial [88].

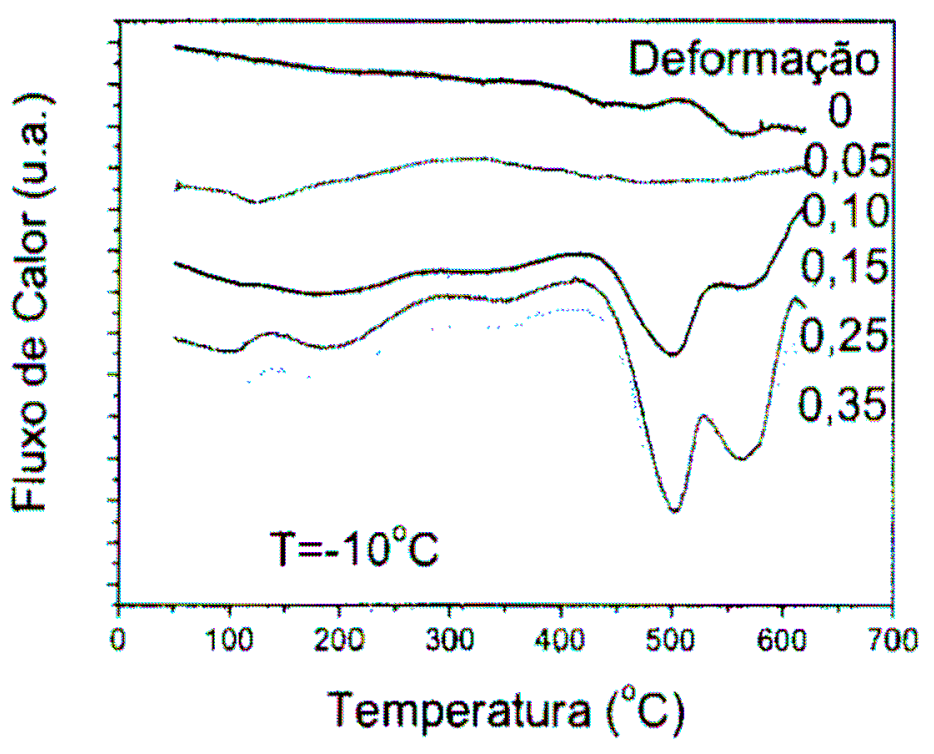

Figura 30 - Curva de DSC para um aço AISI 304 com deformação verdadeira de 0,05 a 0,35 realizada na temperatura de $-10^{\circ} \mathrm{C}[87]$.

- Emissão acústica: Esta técnica tenta associar os sinais de emissão acústica com o início da transformação de fase induzida por deformação. Shaira e coautores [89] publicaram, em 2009, o uso da técnica de emissão acústica como alternativa de monitoramento da transformação de fase induzida por deformação de AISI 304L em corpos de prova submetidos a ensaio de fadiga de baixa ciclagem. Dois canais de sistema de aquisição de $8 \mathrm{MHz}$ e um amplificador de $40 \mathrm{~dB}$ são utilizados para captação de sinais de emissão acústica.

\subsubsection{Modelamento matemático da martensita induzida por deformação}

Uma série de trabalhos envolvendo o modelamento do complexo comportamento da transformação de fase induzida por deformação e as variantes que influenciam este mecanismo estão disponíveis na literatura [73, 90-94]. Apesar de não ser o foco deste trabalho, há disponível na literatura um trabalho publicado recentemente sobre o modelamento do comportamento do aço AISI 304 na transformação de fase induzida por deformação [73]. O modelo proposto na 
simulação chegou muito próximo dos resultados obtido nos experimentos, como pode ser visto na figura 31 abaixo.

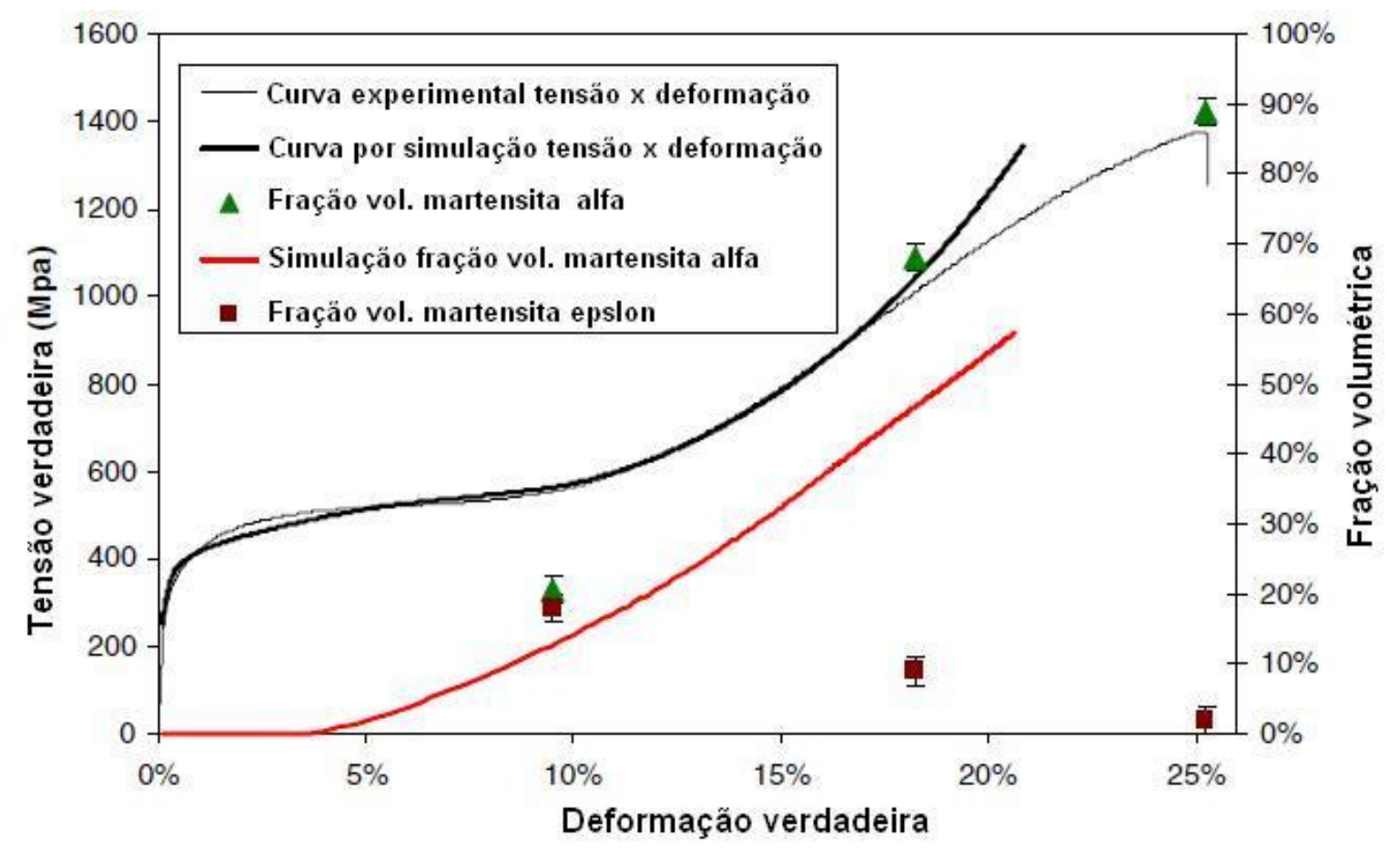

Figura 31 - Curva tensão versus deformação obtida por simulação e experimental [50].

Apesar dos resultados promissores, o aspecto sobre modelamento computacional não será abordado neste trabalho. 


\subsection{Reversão das martensitas $\alpha^{\prime}$ e $\varepsilon$}

A reversão da martensita é o fenômeno pela qual as fases de martensitas metaestáveis $\varepsilon$ e $\alpha$ ' revertem para austenita $\gamma$ em temperaturas elevadas. A faixa de temperatura definida para reversão é diferente para cada fase martensítica e inferior à da recristalização. A reversão da martensita $\varepsilon$ ocorre entre 150 e $400{ }^{\circ} \mathrm{C}$, enquanto a reversão da martensita $\alpha$ ' ocorre entre 400 e $800{ }^{\circ} \mathrm{C}[32,50]$. As figuras 32 (a) e (b) referem-se a um aço AISI 304 tratado termicamente após cerca de 50\% de deformação. Devido ao elevado grau de deformação, provavelmente só houve formação de martensita $\alpha$ ' e por esta razão, a reversão da martensita ocorre em temperaturas mais elevadas. Observa-se na figura 25 que a fração volumétrica de martensita $\alpha$ ' começa a diminuir próximo da temperatura de $500{ }^{\circ} \mathrm{C}$ e atinge zero próximo da temperatura de $750{ }^{\circ} \mathrm{C}$. Conseqüentemente as medidas magnéticas têm o mesmo comportamento e também tendem a zero próximo da temperatura de 750 ${ }^{\circ} \mathrm{C}$. Por outro lado, a dureza diminui, mas com comportamento diferente. A dureza começa a diminuir a $550{ }^{\circ} \mathrm{C}$ e chega ao estado recozido próximo a $1000{ }^{\circ} \mathrm{C}$, pois a microestrutura resultante é a austenita. Na figura 25(b) a microdureza final após a reversão é de aproximadamente $150 \mathrm{HV}$, dureza típica de um aço AISI 304 austenítico recozido. Mészáros e Prohászka [62] comentam que a austenita revertida, geralmente, possui orientação idêntica à austenita original. 


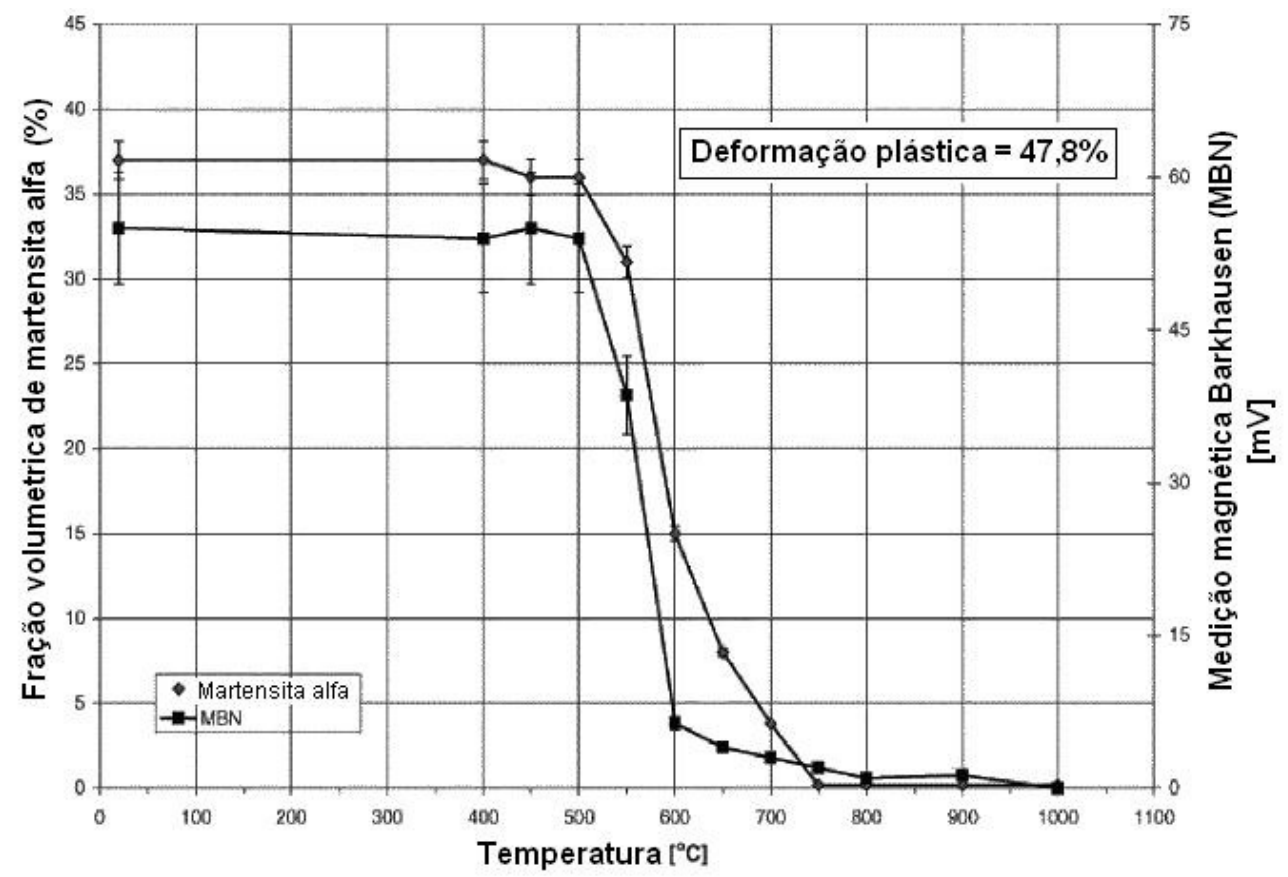

(a)

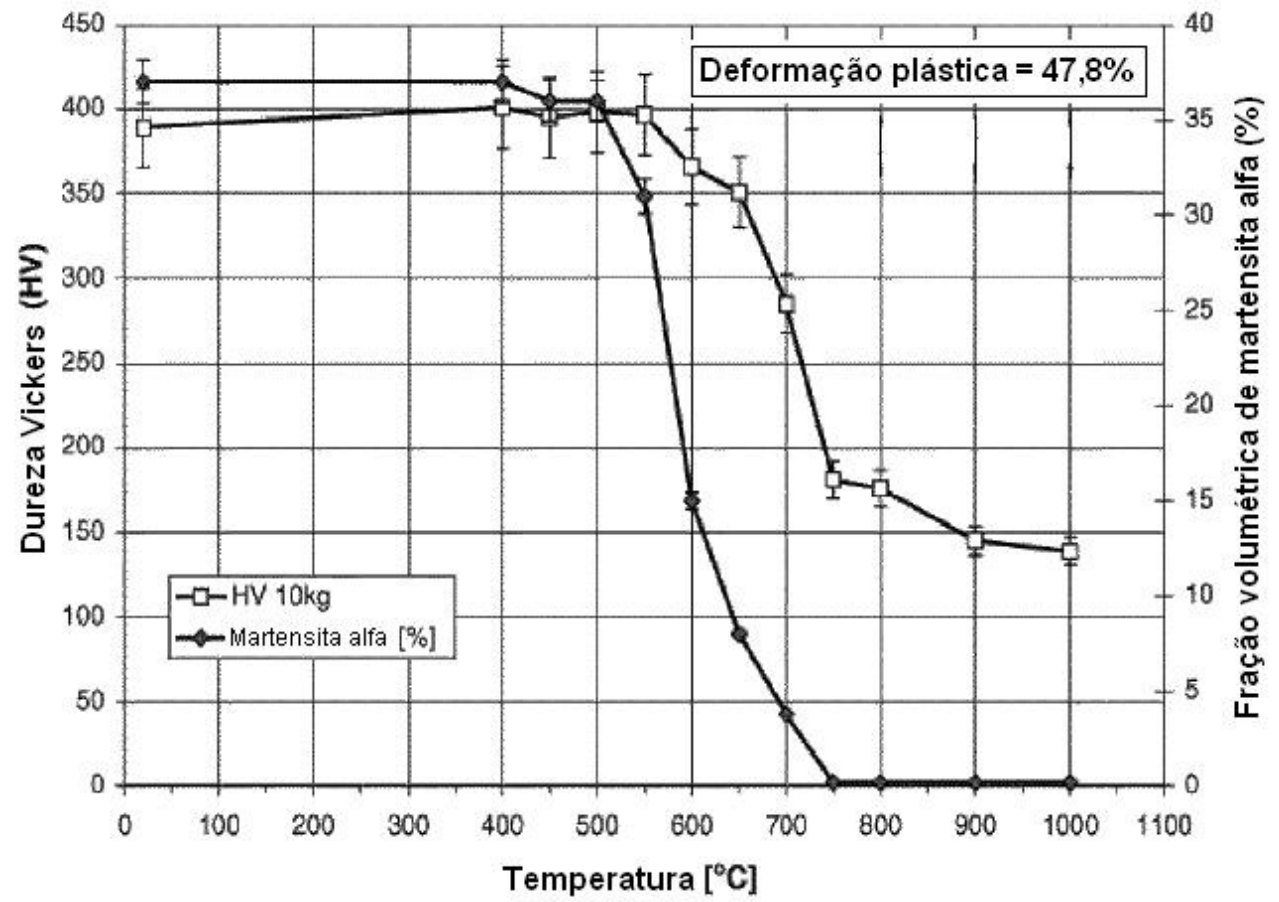

(b)

Figura 32 - Efeito da temperatura na reversão da martensita $\alpha$ ' e consequente efeito na magnetização, microdureza e fração volumétrica de martensita [62].

Nos últimos anos tem havido grande interesse na transformação da técnica de reversão da martensita $\alpha$ ' seguida de severa deformação a frio para o desenvolvimento de grão ultrafinos, na escala nano, para os AIAs [95, 96]. 


\subsection{Resistência à corrosão e passivação}

A propriedade de elevada resistência à corrosão dos aços inoxidáveis é devido ao filme passivo e aderente da superfície, que previne a reação do metal em ambiente corrosivo. A influência dos elementos de liga na resistência a corrosão está relacionada à estabilidade do filme passivo e sua cinética de repassivação [97]. A ruptura do filme de óxido pode ocorrer por meio de ataque químico ou mecânico resultando em corrosão localizada. Para prevenir a corrosão localizada nos Als, é importante que o filme de óxido seja estável com rápida repassivação, mesmo em ambiente agressivo.

Ge e co-autores [98] explicam que a formação do filme de óxido em AIAs apresenta uma estrutura dupla composta por uma camada interna, do tipo barreira, com elevada resistência e rica em óxido de cromo; e outra camada mais externa e porosa, com menor resistência e composta principalmente por óxido de ferro e hidróxidos. Oh e co-autores [99] verificaram que o nitrogênio também está presente no filme passivo, estando em maior quantidade na camada interna. Hakiki e coautores [100] realizaram um estudo em AIAs AISI 304 e 316 e verificaram que a película passiva era composta por duas camadas, uma interna rica em cromo e outra externa rica em ferro.

Algumas técnicas são utilizadas para entender o mecanismo e o processo da formação do filme de óxido, como a microscopia de força atômica e o uso da microscopia eletrônica (varredura e transmissão) combinado à espectroscopia de massa neutra secundária [101]; espectroscopia de fotoelétrons emitidos por raios- $X$ (XPS) e espectroscopia Auger (AES) [55].

A influência de elemento nitrogênio na resistência a corrosão dos AIAs tem sido foco de muitos estudos nos últimos anos [51, 97, 102-104]. Na literatura [97,103-105] existe um consenso geral que a adição de nitrogênio melhora a resistência à corrosão por pite, aumenta o potencial de pite na liga em solução aquosa contendo cloreto, reduz a taxa de corrosão e facilita a repassivação tornando o filme de óxido mais estável. A fim de correlacionar o efeito da concentração dos elementos de liga com a resistência a corrosão por pite, Reed [51] propôs uma equação que define a resistência equivalente por pite $(\mathrm{PRE}=$ Pitting resistance equivalent) conforme indica a equação 10 abaixo: 
onde $X$ é o coeficiente relacionado ao efeito do nitrogênio, sendo válido o valor 16 para aços inoxidáveis duplex e 30 para AIAs [55]. Speidel e Pedrazzoli [52] propuseram uma equação mais complexa, que considera o efeito das concentrações de níquel, manganês e carbono, além do cromo, molibdênio e nitrogênio, conforme indica a equação 11. Esta equação é mais apropriada para ser adotada neste trabalho, devido aos novos desenvolvimentos de AIAs com elevados teores de manganês e nitrogênio. $E$ válido mencionar que os coeficientes propostos para os solutos substitucionais níquel e manganês são o mesmo, porém 60 vezes inferior ao efeito dos solutos intersticiais como o nitrogênio e o carbono.

$$
\mathrm{PRE}=\% \mathrm{Cr}+3,3 \% \mathrm{Mo}+30 \% \mathrm{~N}+0,5 \% \mathrm{Ni}-0,5 \% \mathrm{Mn}-30 \% \mathrm{C}
$$

O conhecimento do comportamento eletroquímico de um metal num potencial de eletrodo diferente do potencial de corrosão (ou de equilíbrio) é de interesse prático e teórico [105]. O processo de corrosão dos metais pode variar dependendo de uma série de fatores como: a temperatura, concentração do ácido, grau de aeração, presença de impureza, densidade de corrente, entre outros [106]. 


\subsection{Anéis de pistão}

Os anéis de pistão possuem três funções básicas em motores de combustão interna [107]:

- Vedar a pressão da câmara de combustão;

- Controlar a lubrificação e o consumo de óleo;

- Servir de meio de transferência de calor do pistão para o cilindro.

Para atingir essas funções, os anéis devem estar em contato com o cilindro em todo o perímetro. A figura 33 indica a montagem dos anéis de pistão considerando um motor de combustão interna. Os anéis têm sua forma livre calculada, produzida e controlada para garantir que, quando montado no motor, o anel irá gerar a pressão radial necessária devido a sua respectiva ação de expansão.

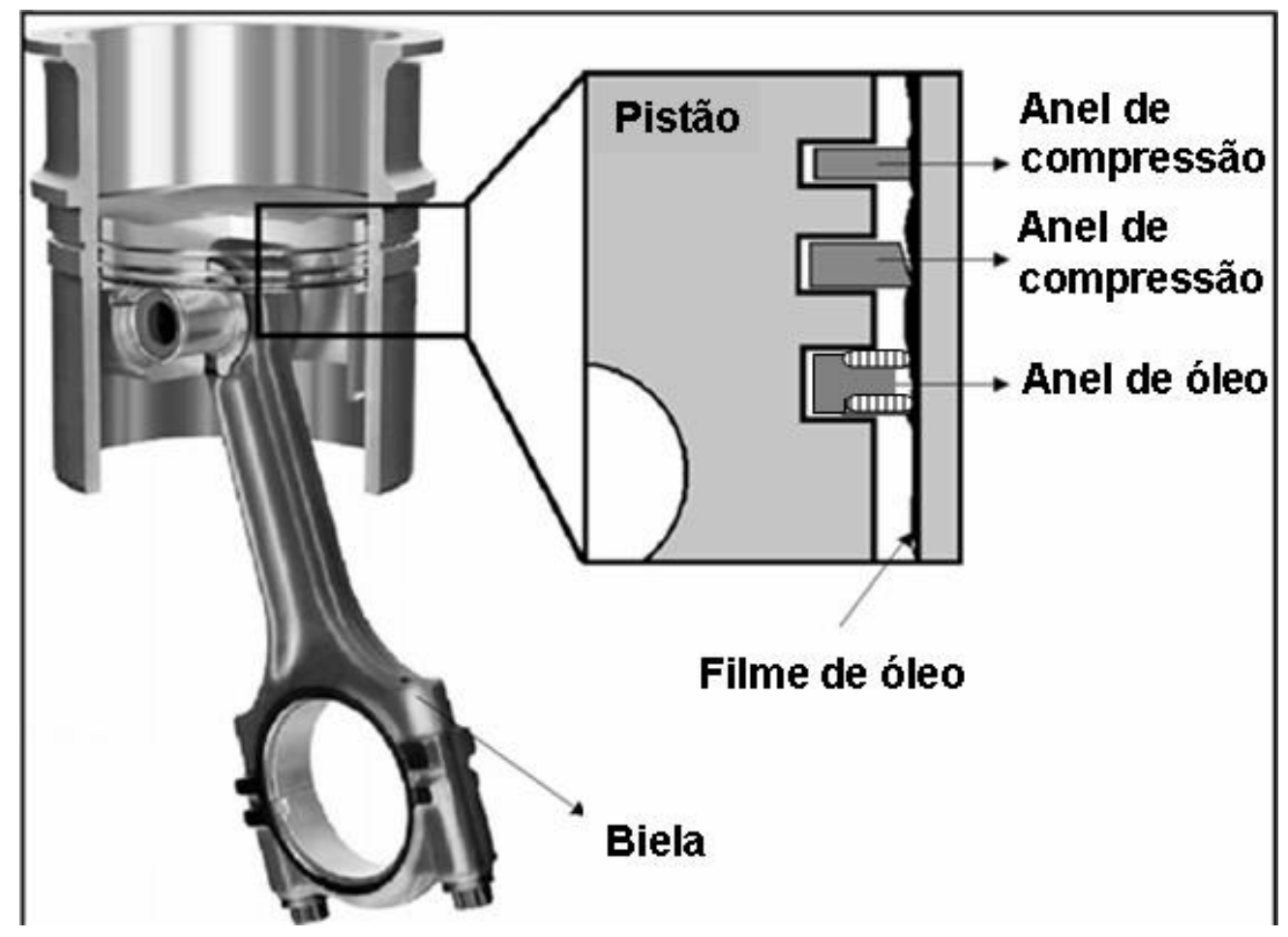

Figura 33 - Desenho esquemático do conjunto pistão-anel-pino-biela-camisa.

Os aços selecionados para este trabalho são aplicados para fabricação de espaçadores que compõe o anel de óleo de três peças, conforme indica a figura 34. A principal vantagem do anel de óleo de três peças é a vedação lateral obtido pelo contato dos segmentos contra o flanco das canaletas. Esta característica evita que 0 
fluxo de óleo passe entre o anel lateral e o flanco da canaleta [108].

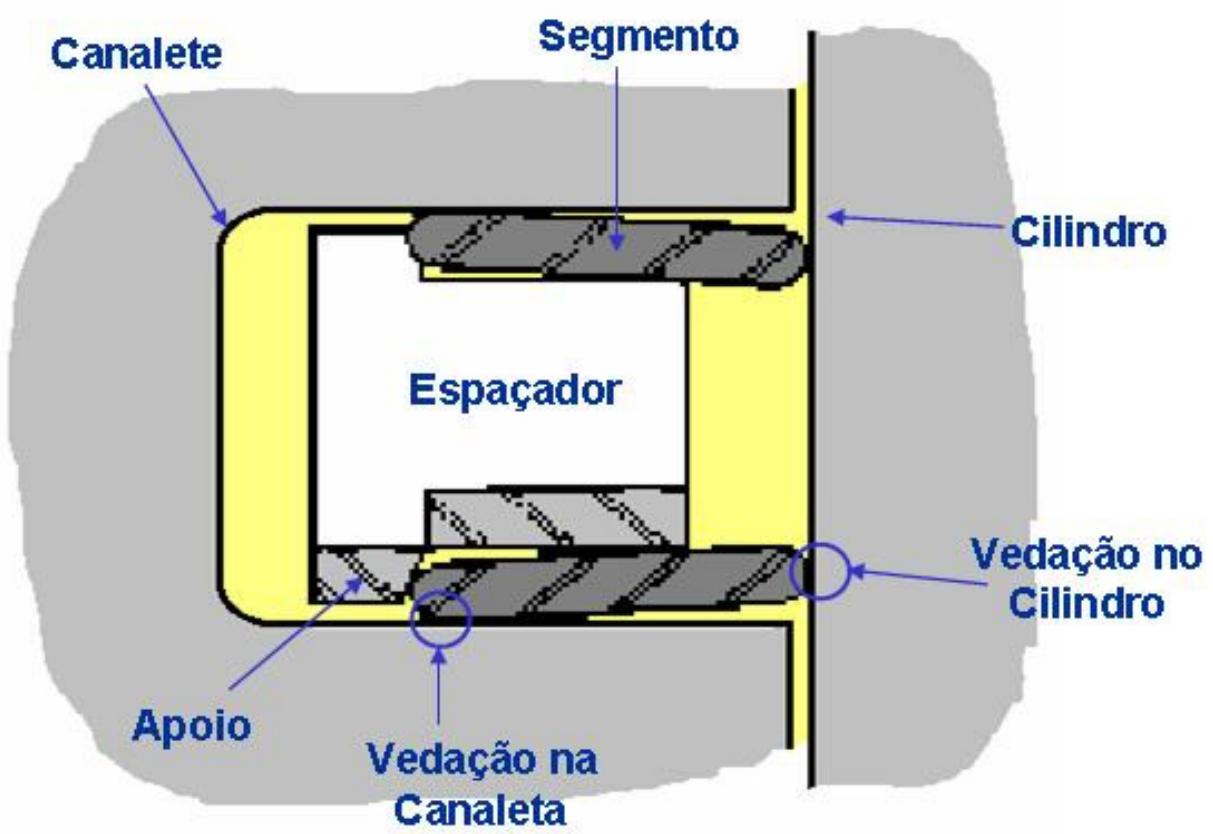

Figura 34 - Desenho esquemático representativo do anel de óleo de três peças.

A produção dos espaçadores dá-se a partir da conformação a frio de fitas de AIA. A partir de uma bobina de AIA, a fita é acoplada a três estágios seqüenciais de engrenagens, conforme indicação da figura 35 . Ao fim do terceiro estágio, obtem-se uma fita severamente conformada, conforme indica a figura 36,37 e 38 .

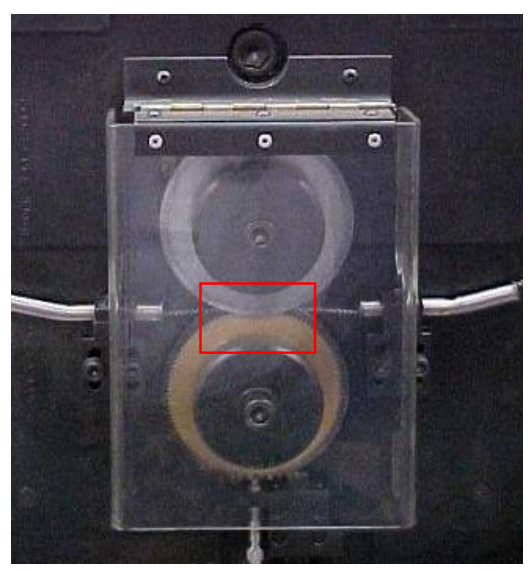

(a)

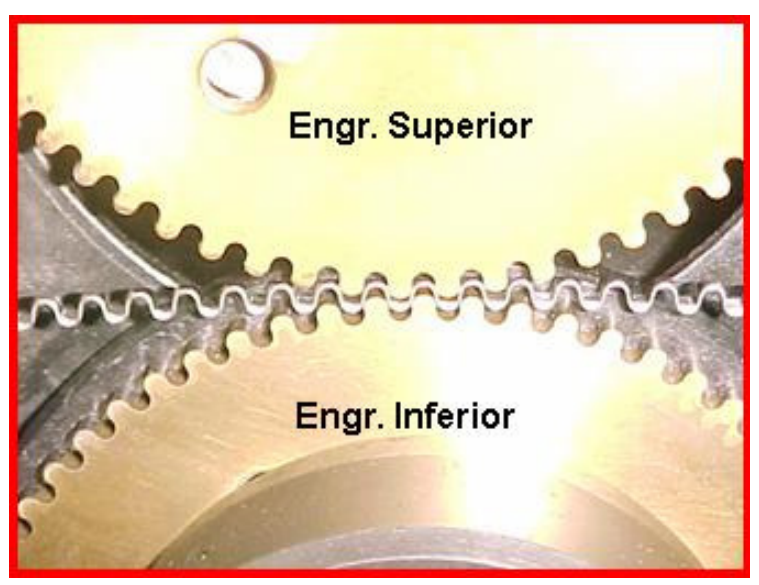

(b)

Figura 35 - Processamento de fabricação do espaçador, (a) um dos três estágios de conformação; (b) detalhe das engrenagens utilizadas durante a conformação a frio. 


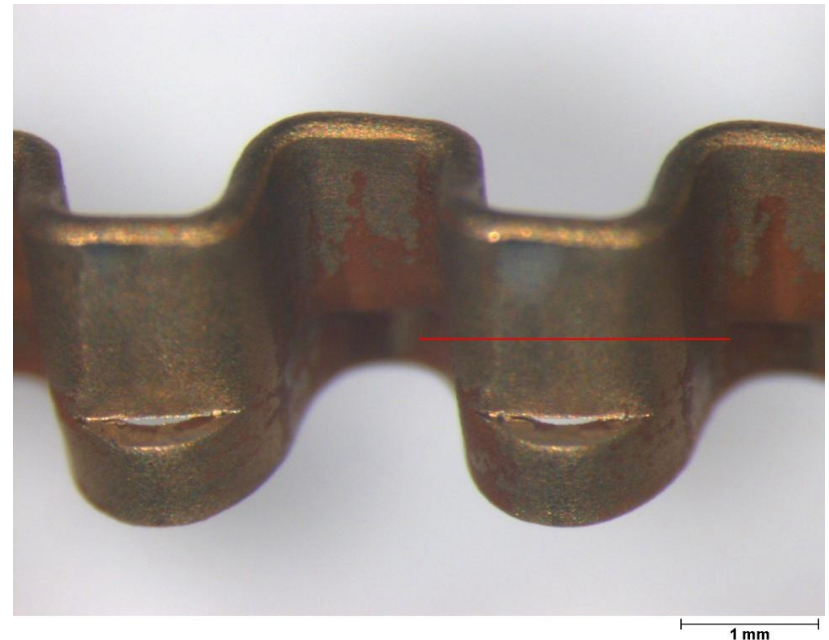

(a)

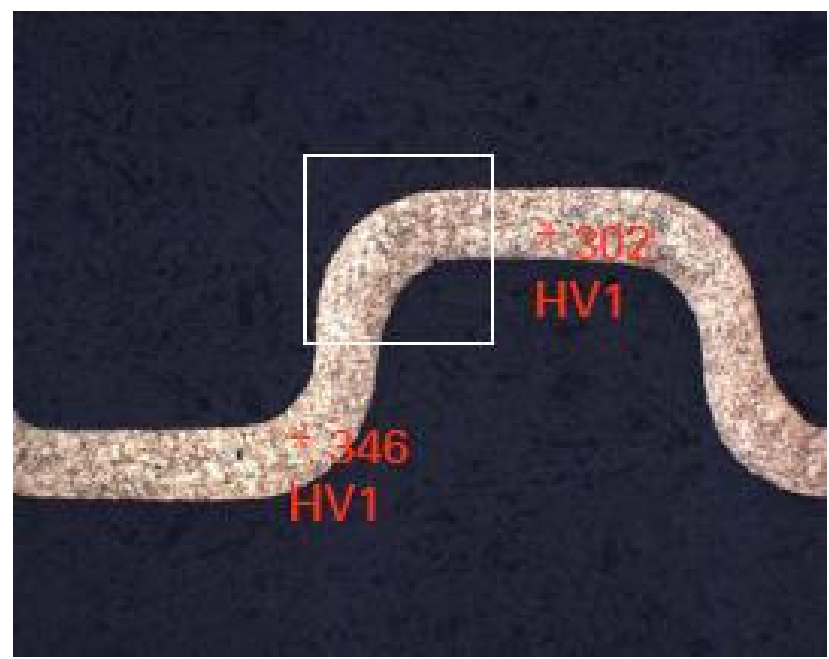

(b)

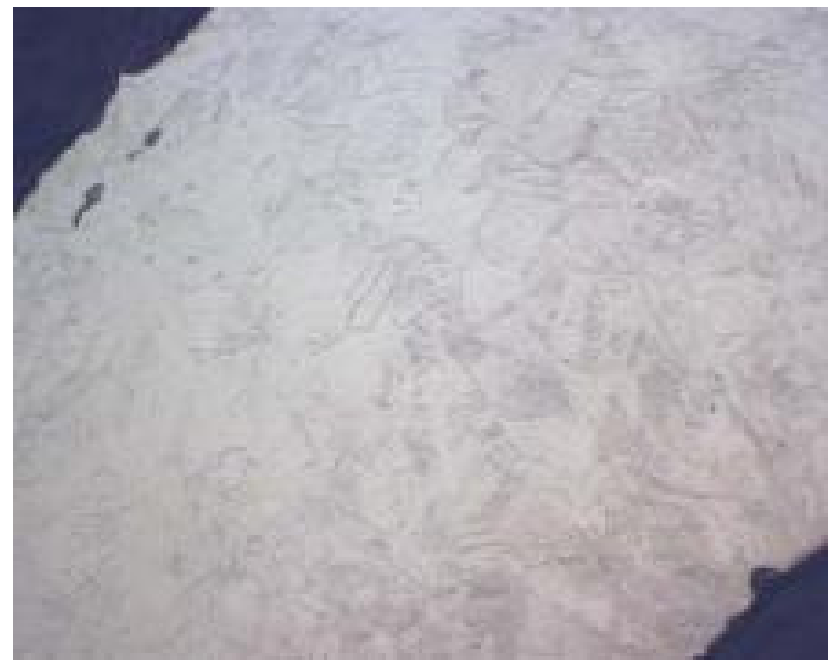

(c)

Figura 36 - Espaçador (a) região de identificação do corte transversal A; (b) visualização do embutimento com 50x de ampliação e ataque Marble; (c) detalhe da microestrutura, ataque ácido oxálico e 100x de ampliação. 


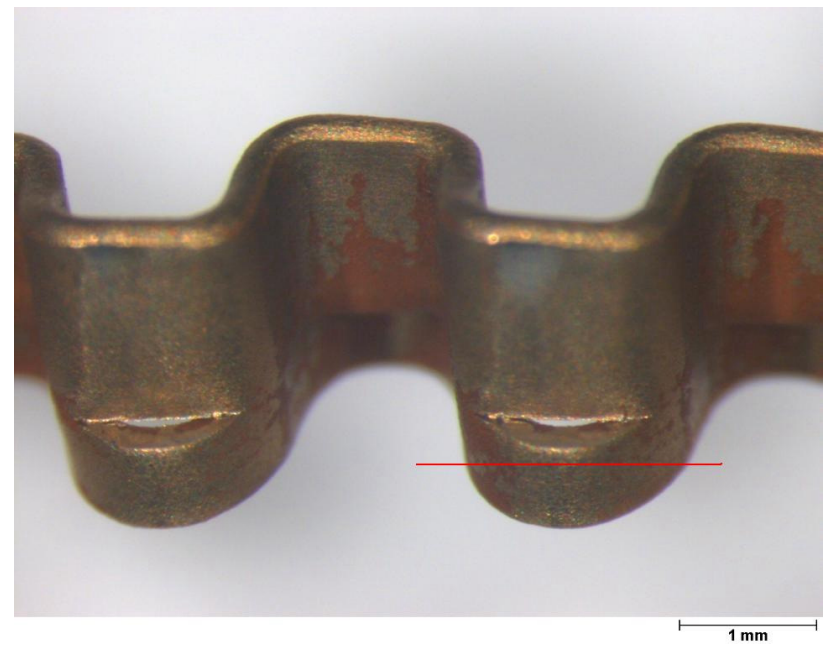

(a)

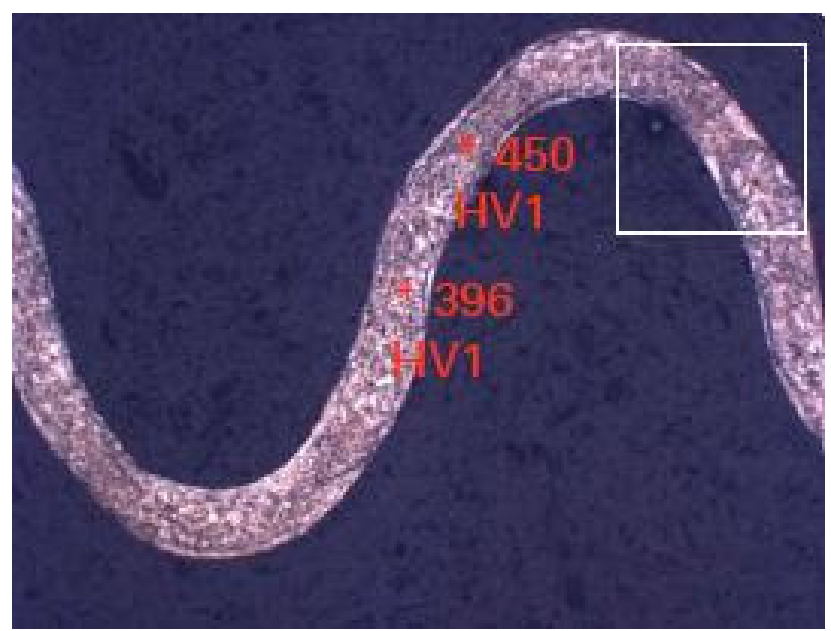

(b)

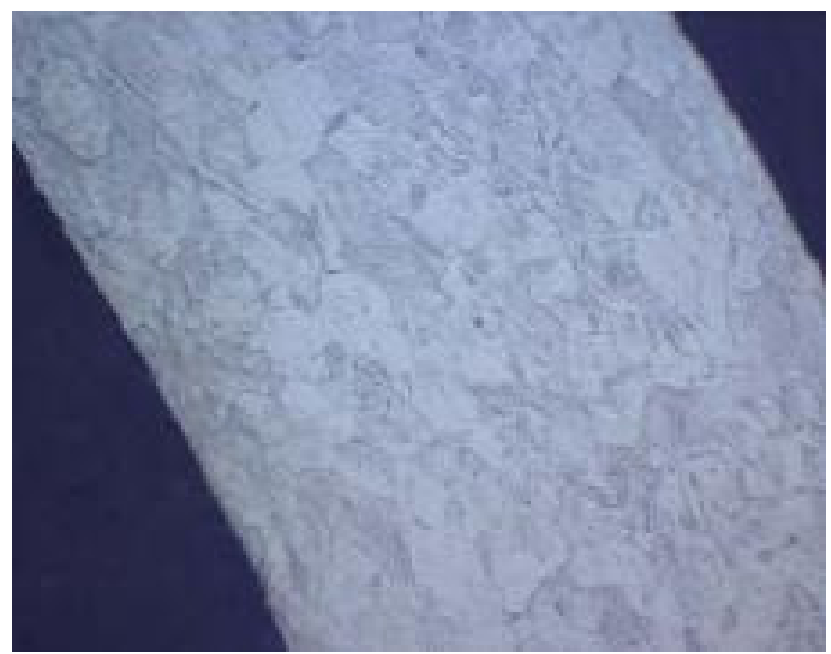

(c)

Figura 37 - Espaçador (a) região de identificação do corte transversal; (b) visualização do embutimento com 50x de ampliação e ataque Marble; (c) detalhe da microestrutura, ataque ácido oxálico e 100x de ampliação. 


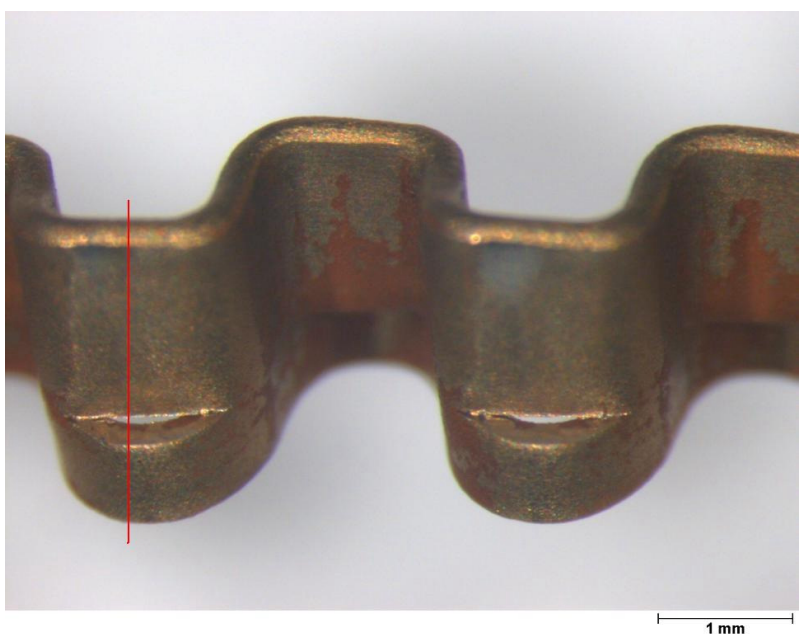

(a)

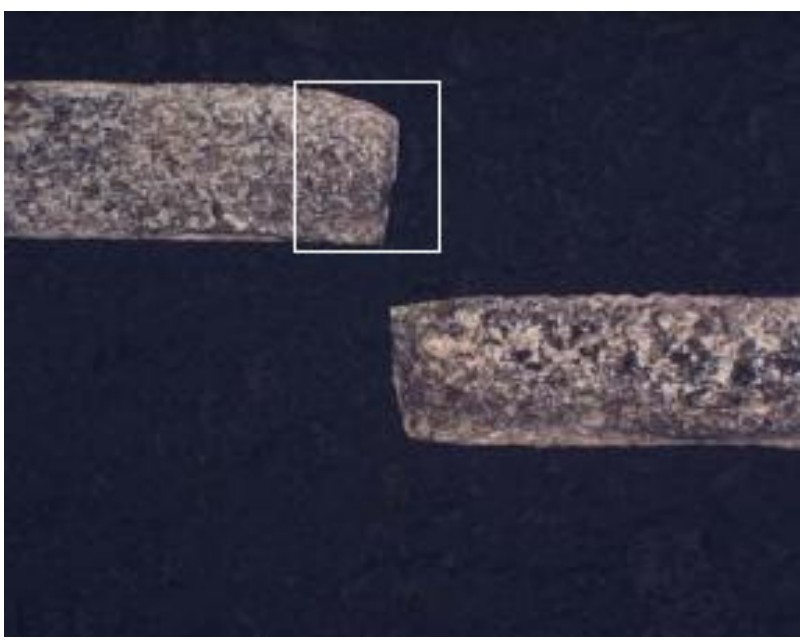

(b)

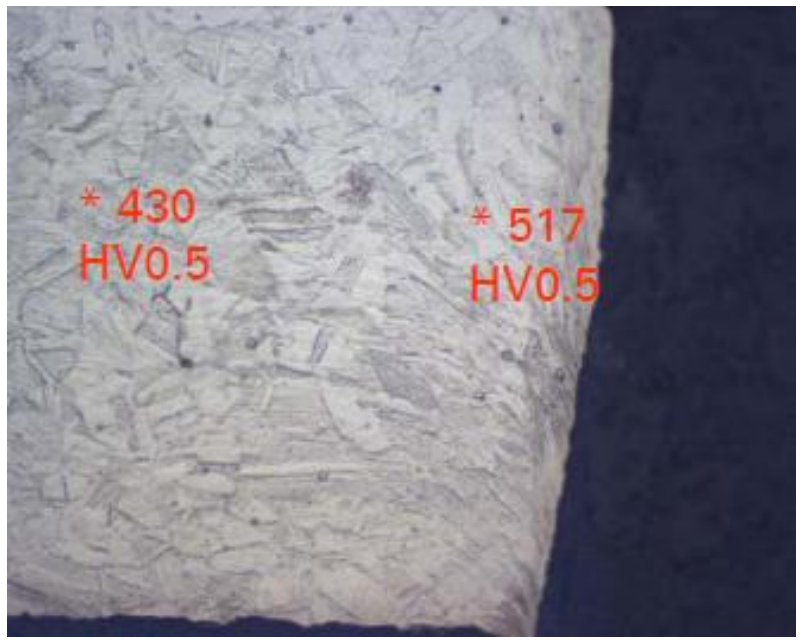

(c)

Figura 38 - Espaçador (a) região de identificação do corte longitudinal; (b) visualização do embutimento com 50x de ampliação e ataque Marble; (c) detalhe da microestrutura, ataque ácido oxálico e 100x de ampliação. 
A norma ISO6621-3 [109] recomenda como especificação de material para aplicação em espaçadores para anel de três peças os AIAs. Neste caso, tanto o aço AISI 201 e o AISI 304 poderiam ser utilizados para a aplicação em espaçadores. As figuras 36, 37 e 38 indicam a caracterização metalográfica de espaçadores produzidos em material AISI 304. Como o espaçador possui uma geometria complexa, diversas secções foram realizadas em diferentes posições do anel. De maneira geral, o espaçador que compõe o anel de óleo possui uma microestrutura tipicamente deformada a frio, com grãos alongados no sentido da conformação. A microestrutura é bifásica e apresenta grãos de austenita e plaquetas de martensita, além da presença de maclas de deformação. Devido à elevada dureza da matriz, podendo atingir até $500 \mathrm{HV}_{0,1}$ em determinadas regiões no anel, conforme indica a figura 38, fica evidente que houve formação de martensita induzida por deformação proveniente do processo de fabricação do anel. Apenas como referência, a dureza típica de um AIA solubilizado é de cerca de $150 \mathrm{HV}_{0,1}$.

A força tangencial é uma das características mais importantes que afeta 0 desempenho do anel de óleo [107]. A perda da força tangencial durante o funcionamento do motor pode prejudicar o desempenho do anel de óleo. A causa da perda da força tangencial pode ser causada por dois fatores:

1. O alívio de tensão do espaçador quando exposto a temperatura do motor em funcionamento;

2. A deflexão do espaçador devido ao desgaste;

Pereira e Bruno [108] fizeram um experimento usando um dispositivo simulando o par pistão/camisa com cinco canaletas, a fim de avaliar a influência do alívio de tensão na perda da força tangencial do espaçador. $O$ conjunto foi imerso em óleo a $200{ }^{\circ} \mathrm{C}$ por 300 horas. A força tangencial foi medida a cada 100 horas de teste, sendo que o resultado obtido pode ser visto na figura 39. 


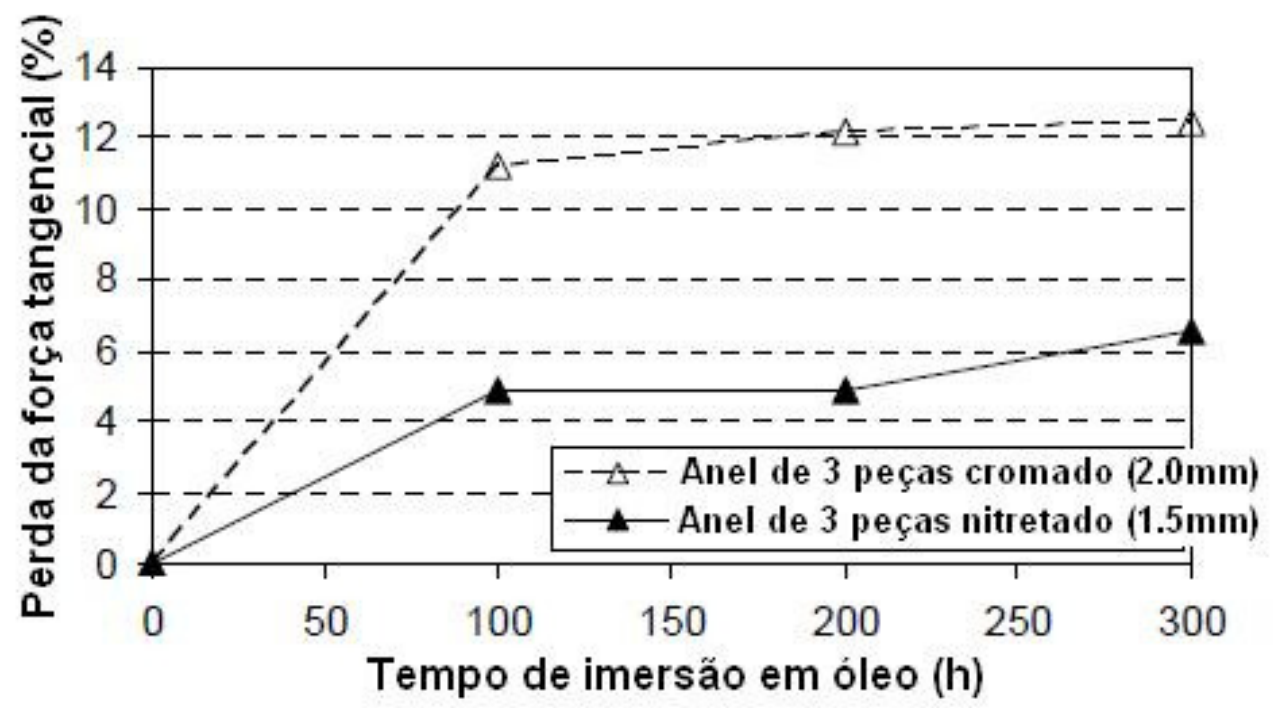

Figura 39 - Perda de força tangencial devido ao efeito térmico em anel de três peças [93].

Pereira e Bruno [108] concluíram que a exposição de anel de três peças a $200{ }^{\circ} \mathrm{C}$ influencia a perda da força tangencial, e conseqüentemente, prejudica seu desempenho durante operação. Há uma significativa diferença de perda da força tangencial quando se altera a largura do anel, mas mesmo para larguras reduzidas, ocorre a perda da força tangencial. Muito provavelmente, este fato está relacionado ao envelhecimento por deformação da martensita [110], fato que justifica a perda de força tangencial durante a operação, o que pode causar o pior desempenho do anel.

Não foi encontrado nenhum trabalho considerando o envelhecimento por deformação em aços inoxidáveis contendo martensita para os aços AISI 201 e AISI 304 selecionados para este trabalho. 


\section{Materiais e métodos}

Neste capítulo foram descritos os materiais selecionados para este trabalho, os tratamentos térmicos utilizados, as técnicas de caracterização microestrutural e os ensaios eletroquímicos empregados.

\subsection{Material}

Os materiais utilizados neste trabalho são dois tipos de aços inoxidáveis austeníticos (AIAs):

- Aço AISI 201, em forma de tira laminada com 0,46 mm de espessura e 2,35 mm de largura. Empresa fabricante do material é a Sandvik, na Suécia.

- Aço AISI 304, em forma de tira laminada com 0,42 mm de espessura e 2,95 mm de largura. Empresa fabricante do material é a Hitachi, no Japão.

\subsection{Análise química}

Dois diferentes AIAs foram selecionados para este trabalho. O aço AISI 304 possui alto teor de $\mathrm{Ni}$ e baixos teores de $\mathrm{C}$ e $\mathrm{Mn}$, o que confere ótimas propriedades de resistência à corrosão em estruturas soldadas [111]. O aço AISI 201 pertence à série 200, apresenta teor de Ni mais baixo que o AISI 304 e elevados teores de Mn e $\mathrm{N}$, os quais substituem o $\mathrm{Ni}$ como elemento estabilizador da austenita [111]. Um dos principais motivos deste trabalho é a análise comparativa do comportamento dos aços AISI 201 e 304 na transformação de fase induzida por deformação e a verificação da resistência à corrosão, devido à diferença de composição química. $A$ especificação da composição química dos aços AISI 201 e AISI 304 está expressa, em porcentagem em massa, na tabela 8.

A composição química dos aços foi realizada com o auxílio da técnica de espectrometria de emissão óptica com acoplamento induzido de plasma (ICP). $\mathrm{O}$ ICP é de propriedade da MAHLE Metal Leve S/A e está instalado nas dependências do Centro de Tecnologia em Jundiaí. 
Tabela 8 - Especificação da composição química dos aços inoxidáveis austeníticos (\% em massa).

\begin{tabular}{ccc}
\hline Elementos & $\begin{array}{c}\boldsymbol{A} \text { ISI 201 } \\
\text { Especificado }\end{array}$ & $\begin{array}{c}\text { AISI 304 } \\
\text { Especificado }\end{array}$ \\
\hline $\mathrm{C}$ & $<0,15$ & $<0,08$ \\
$\mathrm{Cr}$ & $16,00-18,00$ & $18,00-20,00$ \\
$\mathrm{Ni}$ & $3,50-5,50$ & $8,00-10,50$ \\
$\mathrm{Mn}$ & $5,50-7,50$ & $<2,00$ \\
$\mathrm{Si}$ & $<1,0$ & $<1,00$ \\
$\mathrm{P}$ & $<0,060$ & $<0,045$ \\
$\mathrm{~S}$ & $<0,030$ & $<0,030$ \\
$\mathrm{~N}$ & $<0,25$ & -- \\
$\mathrm{Fe}$ & Balanço & Balanço \\
\hline
\end{tabular}

\subsection{Solubilização}

Inicialmente, todas as amostras dos aços AISI 201 e AISI 304 foram solubilizadas a $1050{ }^{\circ} \mathrm{C}$ por 30 minutos em atmosfera inerte de argônio e, posteriormente, resfriadas em água a temperatura ambiente. O tratamento foi realizado no forno horizontal tubular Lindberg, disponível no laboratório de processos metalúrgicos da Escola Politécnica da USP. Este tratamento tem como objetivo a solubilização da fase ferrita (e/ou precipitado que houver no material na condição "como recebida").

Algumas amostras também foram tratadas na condição sub-zero em nitrogênio líquido (cerca de $-196^{\circ} \mathrm{C}$ ) por 1 hora. O tratamento sub-zero visa a eventual transformação de fase espontânea pelo resfriamento abaixo da temperatura $\mathrm{M}_{\mathrm{s}}$ para efeito comparativo ao calculo da mesma temperatura, conforme foi descrito na revisão bibliográfica. 


\subsection{Laminação}

A condição estabelecida para início da etapa de laminação foi a temperatura ambiente, cerca de $25^{\circ} \mathrm{C}$. Diferentes reduções de espessura foram estudadas neste trabalho com o auxílio de um laminador quadruo, conforme a equação (12) a seguir:

$$
r=\left[\left(e_{i}-e_{f}\right) / e_{i}\right] * 100
$$

onde, $r$ significa a redução em porcentagem, $e_{f}$ a espessura final da tira após laminação e $e_{i}$ a espessura inicial da tira, descrita no item 3.1. As reduções adotadas neste trabalho foram:

- $5 \%$

- $10 \%$;

- $15 \%$;

- $20 \%$;

- $25 \%$;

- 30\%;

As amostras foram laminadas a seco, sem o uso de lubrificação e sempre unidirecionalmente. As amostras obtidas foram utilizadas para construir a curva de endurecimento por deformação (encruamento) e estudar a evolução da quantidade de martensita induzida por deformação formada. A velocidade de laminação estabelecida para os experimentos deste trabalho foi de $10 \mathrm{~mm} / \mathrm{min}$. O laminador utilizado pertence à MAHLE Metal Leve S/A e está instalado nas dependências da unidade de São Bernardo do Campo.

\subsection{Ensaio de tração}

O ensaio de tração foi realizado a fim de determinar as propriedades mecânicas dos aços AISI 201 e AISI 304, como o limite de escoamento, limite de resistência, alongamento e módulo de elasticidade. Devido à restrição de espessura das tiras de aço, não foi possível confeccionar corpos de prova (CP) conforme recomendação da norma ASTM E8M. As próprias tiras solubilizadas foram testadas em ensaio de tração com taxa de deformação de $10 \mathrm{~mm} / \mathrm{min}$. Além do teste de 
tração até a ruptura, outros ensaios foram interrompidos em diferentes graus de deformação, os mesmos descritos para os testes de laminação. O comprimento da tira a ser testado foi definido com o auxílio da equação 13 a seguir:

$$
L_{0}=5,65 \times A^{1 / 2}
$$

onde, $A$ e $L_{0}$ representam a área da secção transversal e o comprimento, respectivamente. Para avaliar o efeito da taxa de deformação nas propriedades mecânicas dos aços AISI 201 e AISI 304, ensaios de tração foram realizados em diferentes velocidades:

- $1 \mathrm{~mm} / \mathrm{min}$;

- $10 \mathrm{~mm} / \mathrm{min}$;

- $30 \mathrm{~mm} / \mathrm{min}$;

A velocidade descrita acima representa a velocidade que o dispositivo que prende a fita de aço está sendo imposta durante o ensaio de tração. A taxa de deformação que a fita sofre é referente à $L_{0}$ Os testes foram realizados no equipamento MTS 810, que pertence a MAHLE Metal Leve S/A e está instalado nas dependências do Centro de Tecnologia em Jundiaí.

\subsection{Técnicas de análise microestrutural}

Todas as amostras processadas neste trabalho foram caracterizadas com 0 auxílio de uma série de técnicas complementares para avaliação microestrutural, tais como microscopia óptica (MO), microscopia eletrônica de varredura (MEV), difração de raios $\mathrm{X}$, medidas magnéticas (Ferritoscópio) e medição de microdureza Vickers.

\subsubsection{Microscopia óptica}

A microestrutura foi avaliada após preparação metalográfica adequada. As amostras foram cortadas, embutidas em baquelite, lixadas, polidas e atacadas. A operação de lixamento dos corpos de prova seguiu a sequência de granas: 120, 220, 320, 400, 600 e 1000 \#. Logo após, as amostras foram polidas em diamante 6, 3 e $1 \mu \mathrm{m}$, finalizando o polimento com suspensão de sílica coloidal Struers. 
$\mathrm{O}$ ataque selecionado para revelar a microestrutura dos AIAs em todas as condições ("como recebida", solubilizada, laminada e tracionada) foi o ácido oxálico eletrolítico. A composição utilizada para obter o reagente foi $10 \mathrm{~mL}$ de ácido oxálico e $100 \mathrm{~mL}$ de água $\left(\mathrm{H}_{2} \mathrm{O}\right)$ em concentração de 10\%, por 30 segundos de imersão, temperatura ambiente (cerca de $25^{\circ}$ ) e $4,5 \mathrm{~V}$ [112].

A microscopia óptica também foi utilizada para a análise quantitativa [113] dos aços AISI 201 e 304, especificamente o tamanho de grão, seguindo a norma ASTM E112 [114]. A avaliação de inclusão conforme norma ASTM E45 [115] também foi realizada como complementação de análise qualitativa.

Todos os equipamentos de embutimento, lixadeiras, politrizes e microscópios ópticos pertencem a MAHLE Metal Leve S/A e estão instalados nas dependências do Centro de Tecnologia em Jundiaí.

\subsubsection{Microscopia eletrônica de varredura}

A técnica de microscopia eletrônica de varredura (MEV) foi utilizada para caracterização das amostras após os ensaios eletroquímicos. As imagens de elétrons secundários e de elétrons retroespalhados foram utilizadas, além da análise de energia dispersiva (EDS), cujo detector está acoplado ao MEV utilizado. O modelo do equipamento é o Philips FEI Quanta 600.

O MEV utilizado pertence à MAHLE Metal Leve S/A e está instalado nas dependências do Centro de Tecnologia de Jundiaí.

\subsubsection{Difração de raios $X$}

A análise de DRX foi feita na superfície das tiras nas quatro condições, "como recebida", solubilizada, laminada e tracionada para identificação de fases presentes no material. Devido à restrição de espessura das amostras, a análise foi realizada apenas na superfície das tiras. O equipamento utilizado foi um difratômetro modelo jdxIlp3a da JEOL, com passo angular de 0,05 ', ângulo inicial de $30^{\circ}$ e ângulo final de $110^{\circ}$ e tempo de aquisição de 7 segundos por step. A radiação utilizada para as análises foi de cobre / $\operatorname{CuK} \alpha(\lambda=0,15405 \mathrm{~nm})$ com auxílio de monocromador. $O$ 
equipamento de DRX utilizado pertence à MAHLE Metal Leve S/A e está instalado nas dependências do Centro de Tecnologia em Jundiaí.

As amostras solubilizadas, laminadas e tracionadas foram decapadas antes do início das análises de difração para evitar interferência dos resultados. Como sugerido no trabalho de De e co-autores [85], a solução utilizada para decapar o óxido da superfície foi uma mistura de ácido clorídrico, ácido nítrico e água destilada na proporção de 1:1:1. Após alguns testes, o tempo e temperatura de permanência dos aços em solução para remoção do óxido da superfície foi definido em 5 minutos a $60{ }^{\circ} \mathrm{C}$.

\subsubsection{Medidas magnéticas}

O equipamento ferritoscópio foi utilizado para verificar a presença de magnetismo ou de fases magnéticas nos materiais AISI 201 e AISI 304. O ferritoscópio é da marca Fisher, modelo MP3 e possui limite de detecção de 0,1\% de fase ferromagnética. A análise de medidas magnéticas foi realizada na superfície das tiras de todas as condições "como recebida", solubilizada, laminada e tracionada. Devido à restrição de espessura das amostras, não foi realizada a análise em outros pontos além da superfície. O equipamento utilizado está disponível no Departamento de Engenharia Metalúrgica e de Materiais da Escola Politécnica da USP.

\subsubsection{Dureza Vickers}

A medida de dureza foi realizada em todas as condições de processamento dos AIAs AISI 201 e AISI 304 com carga de 100 g, conforme norma ASTM-384-09 [116]. O equipamento utilizado foi o micro-durômetro Shimadzu, modelo HMV-2000, com limite de cargas de $5 \mathrm{~g}$ a $2 \mathrm{~kg}$. O durômetro é de propriedade da MAHLE Metal Leve S/A e está instalado nas dependências do Centro de Tecnologia em Jundiaí.

\subsection{Ensaios eletroquímicos utilizados neste trabalho}


Os métodos eletroquímicos mais convencionais adotados neste estudo foram a espectroscopia de impedância eletroquímica (EIE) e a polarização potenciodinâmica anódica $(55,98,100,117-119)$. Foi utilizado um arranjo experimental de três eletrodos, com um eletrodo de calomelano saturado (ECS) como eletrodo de referência, um fio de platina como contra eletrodo e a amostra como o eletrodo de trabalho. Uma célula eletroquímica com capacidade para $250 \mathrm{~mL}$ de solução, construída em vidro e polietileno, foi utilizada nos ensaios. Essa célula permitia posicionar os eletrodos de trabalho na posição vertical conforme mostrado no desenho esquemático conforme indicação da figura 40. Devido à espessura das amostras, não foi possível a realização prévia da preparação metalográfica da superfície.

Os eletrodos de trabalho foram embutidos com resina epóxi de cura a frio (epofix), deixando uma das áreas para exposição ao meio de ensaio. Os eletrodos de trabalho foram desengraxados com detergente em banho utrassônico durante 5 minutos, enxaguados com água deionizada e secos com soprador térmico [120].

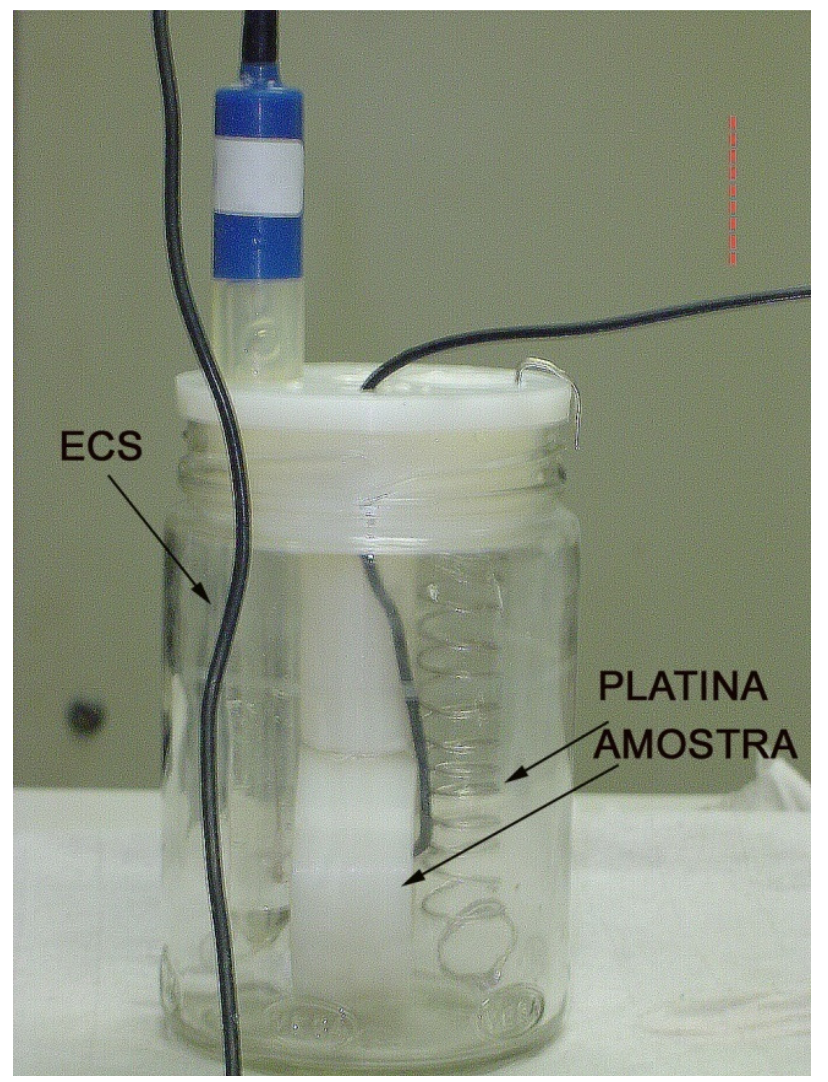

Figura 40 - Desenho esquemático da célula utilizada nos ensaios eletroquímicos. [120] 
Os ensaios eletroquímicos foram feitos após 24 horas de imersão em uma solução salina tamponada com fosfato (Phosphate Buffered Saline Solution-PBS), à temperatura de $25{ }^{\circ} \mathrm{C}$ e em condições de aeração natural, simulando a composição dos fluidos fisiológicos. A composição química da solução é dada na tabela 9 a seguir. A solução de PBS foi selecionada para este trabalho, pois ela é simular ao meio fisiológico. Como esses aços também podem ser aplicados como biomateriais; metálicos implantados num organismo vivo estão expostos à ação corrosiva do meio fisiológico, cuja agressividade é comparável à da água do mar.

Tabela 9 - Composição química do meio PBS [121].

\begin{tabular}{cc}
\hline Composto & $\boldsymbol{m g} / \boldsymbol{L}$ \\
\hline $\mathrm{NaCl}$ & 8,770 \\
$\mathrm{Na}_{2} \mathrm{HPO} 4$ & 1,420 \\
$\mathrm{KH}_{2} \mathrm{PO}_{4}$ & 2,720 \\
\hline
\end{tabular}

\subsubsection{Espectroscopia de impedância eletroquímica (EIE)}

Espectroscopia de impedância eletroquímica (EIE) é uma técnica bastante utilizada para o estudo e avaliação do comportamento eletroquímico de materiais metálicos e para verificação de sua resistência à corrosão. Em razão de ser um ensaio não destrutivo, essa técnica possibilita a realização de ensaios em função do tempo e, dessa forma, prever o comportamento em ensaios de longa duração [55].

Os ensaios de EIE foram realizados em um frequencímetro Gamry Potentiostat, na faixa de freqüências de $10 \mathrm{kHz}$ a $10 \mathrm{mHz}$, com duração de cerca de 30 minutos, amplitude de perturbação de $10 \mathrm{mV}$ e taxa de aquisição de 10 pontos por década. Os ensaios foram realizados no Laboratório de Corrosão do Instituto de Pesquisas Energéticas e Nucleares.

\subsubsection{Polarização Potenciodinâmica anódica}

Os objetivos do ensaio de polarização potenciodinâmica anódica foram a obtenção de informações sobre a resistência à corrosão por pite e a estabilidade dos óxidos formados para os aços AISI 201 e AISI 304. As curvas de polarização 
potenciodinâmica foram iniciadas no potencial de corrosão, uma vez que os potenciais catódicos alteram as características das camadas de óxido nas superfícies dos materiais testados.

As medidas de polarização potenciodinâmica foram realizadas com auxílio de um potenciostato Gamry, com taxa de varredura de $1 \mathrm{mV} . \mathrm{s}^{-1}$ desde $-200 \mathrm{mV}$ até que a densidade de corrente atingisse o valor de $1 \mathrm{~mA} / \mathrm{cm}^{2}$. Estas condições de ensaio foram determinadas visando à comparação dos resultados com outros trabalhos [55, 120 , 122] também realizados no Laboratório de Corrosão do Instituto de Pesquisas Energéticas e Nucleares.

\subsection{Reversão da martensita}

Para avaliar o efeito do tratamento térmico e determinar a faixa de temperatura que ocorre a reversão da martensita para austenita, diversos tratamentos térmicos foram realizados. Uma mufla foi utilizada para a realização dos tratamentos térmicos, com auxílio de um termopar durante todo o tratamento. As temperaturas selecionadas foram: 400, 450, 500, 550, 600, 650 e $700{ }^{\circ} \mathrm{C}$ pelo período de 1 hora em ar, sem uso de atmosfera inerte. Após o tratamento, as amostras foram resfriadas ao ar, fora do forno. As amostras tratadas foram posteriormente embutidas e passaram pela preparação metalográfica para avaliação de microdureza. 


\section{$3 \quad$ Resultados e discussão}

Neste capítulo foram descritos e discutidos os resultados obtidos com auxílio de várias técnicas complementares de análise microestrutural.

\subsection{Material como recebido}

Inicialmente, os dois aços escolhidos para a realização do trabalho, AISI 201 e AISI 304, foram caracterizados na condição como recebida.

\subsubsection{Composição química}

A composição química dos aços foi determinada com auxílio da técnica de espectrometria de emissão óptica com acoplamento induzido de plasma (ICP) e os resultados são apresentados na tabela 10. Os valores estão de acordo com a especificação, conforme descrito no item 2.2.

Tabela 10 - Composição química (\% em massa) dos aços pesquisados.

\begin{tabular}{ccc}
\hline Elementos & $\begin{array}{c}\text { AISI 201 } \\
\text { Determinado }\end{array}$ & $\begin{array}{c}\text { AlSI 304 } \\
\text { Determinado }\end{array}$ \\
\hline $\mathrm{C}$ & 0,092 & 0,053 \\
$\mathrm{Cr}$ & 17,26 & 18,84 \\
$\mathrm{Ni}$ & 3,98 & 9,18 \\
$\mathrm{Mn}$ & 6,23 & 1,05 \\
$\mathrm{Si}$ & 0,39 & 0,46 \\
$\mathrm{P}$ & 0,012 & 0,018 \\
$\mathrm{~S}$ & 0,002 & 0,004 \\
$\mathrm{~N}$ & 0,090 & 0,048 \\
$\mathrm{Fe}$ & Balanço & Balanço \\
\hline
\end{tabular}

Com os resultados de análise química disponíveis, foi possível calcular os valores de cromo equivalente $\left(\mathrm{Cr}_{\text {eq }}\right)$ e níquel equivalente $\left(\mathrm{Ni}_{\mathrm{eq}}\right)$ para inserir no diagrama de Schaeffler. Ao invés de calcular os equivalentes utilizando-se apenas a equação de Schaeffler, foram utilizadas várias equações para o cálculo dos valores 
de $\mathrm{Cr}_{\text {eq }}$ e $\mathrm{Ni}_{\text {eq }}$, conforme ilustra a figura 41. De acordo com revisão apresentada na dissertação de mestrado de Tavares [64], existem numerosas fórmulas para o cálculo dos valores de $\mathrm{Cr}_{\text {eq }}$ e $\mathrm{Ni}_{\text {eq }}$, as quais atribuem diferentes valores para os elementos de liga presentes no aço. Dentre todos os valores de $\mathrm{Cr}_{\text {eq }}$ e $\mathrm{Ni}_{\text {eq }}$ calculados utilizando-se as diferentes equações apresentadas em [64], a equação que melhor se adequa com as determinações experimentais para os dois aços selecionados neste trabalho é a de DeLong [10], diferentemente da equação de Schaeffler [8] que é muito utilizada para previsões microestruturais de AIAs da série 300. A explicação para isto é que a fórmula de DeLong considera mais adequadamente os efeitos do manganês e do nitrogênio. Vale ressaltar que não foi encontrado na literatura indicação de cálculo de níquel e cromo equivalente para os AIAs da série 200.

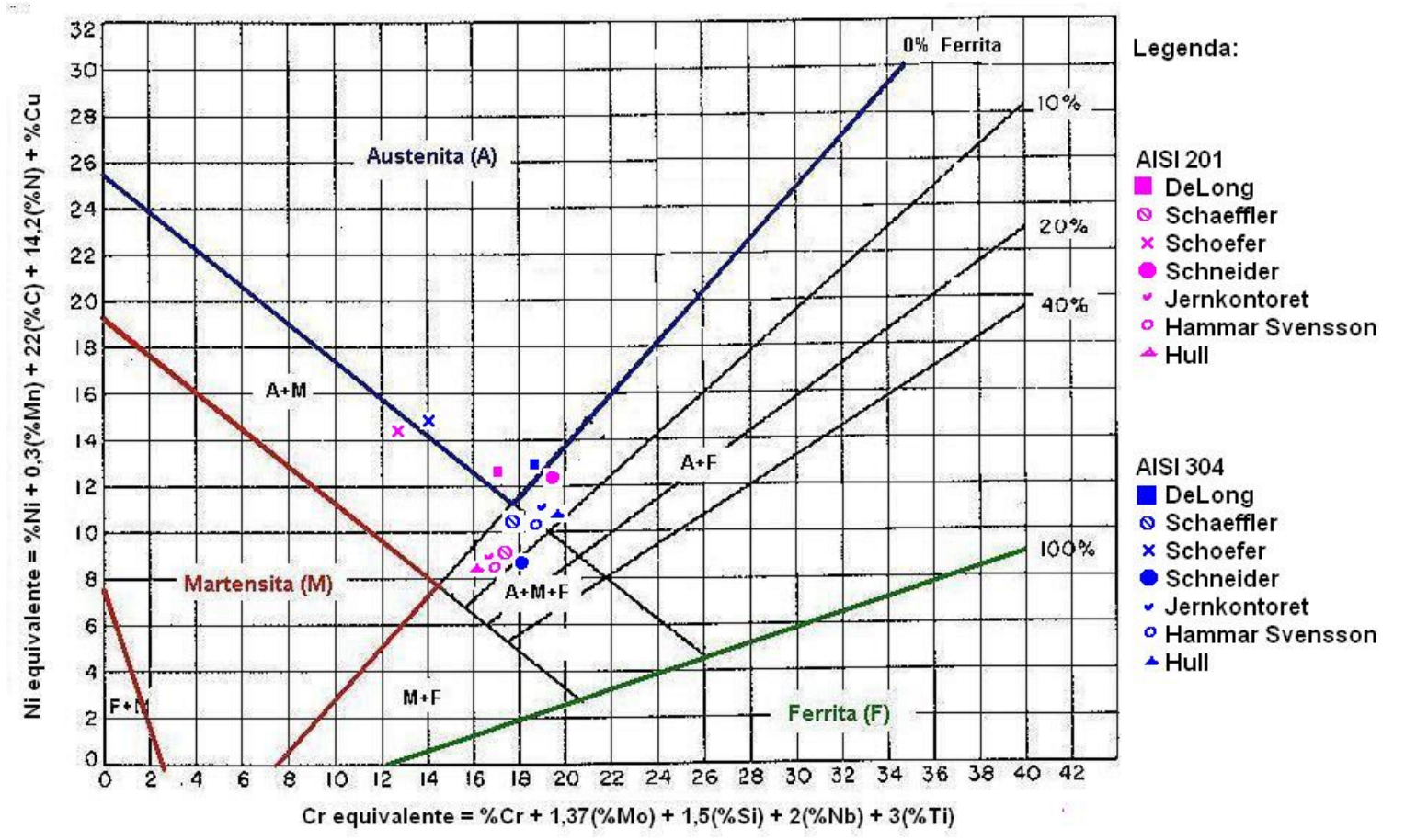

Figura 41 - Diagrama de Schaeffler modificado com as previsões de microestrutura para os aços AISI 201 e AISI 304 deste trabalho.

Os valores de $\mathrm{Cr}_{\text {eq }}$ e $\mathrm{Ni}_{\text {eq }}$ calculados seguindo a equação de DeLong [10] indicam que os dois aços AISI 201 e AISI 304 terão microestrutura austenítica. Como parte dos resultados obtidos neste trabalho, uma análise crítica foi feita, dentre as equações disponíveis na literatura, para verificar qual é mais indicada para os aços da série 200. 


\subsubsection{Caracterização metalográfica}

As fitas de AIAs foram caracterizadas na condição "como recebida". A figura 42 mostra as microestruturas típicas dos aços AISI 201 e 304, obtidas por microscopia óptica (MO) após utilização de ataque de ácido oxálico para revelar a microestrutura com ampliação de 1000x.

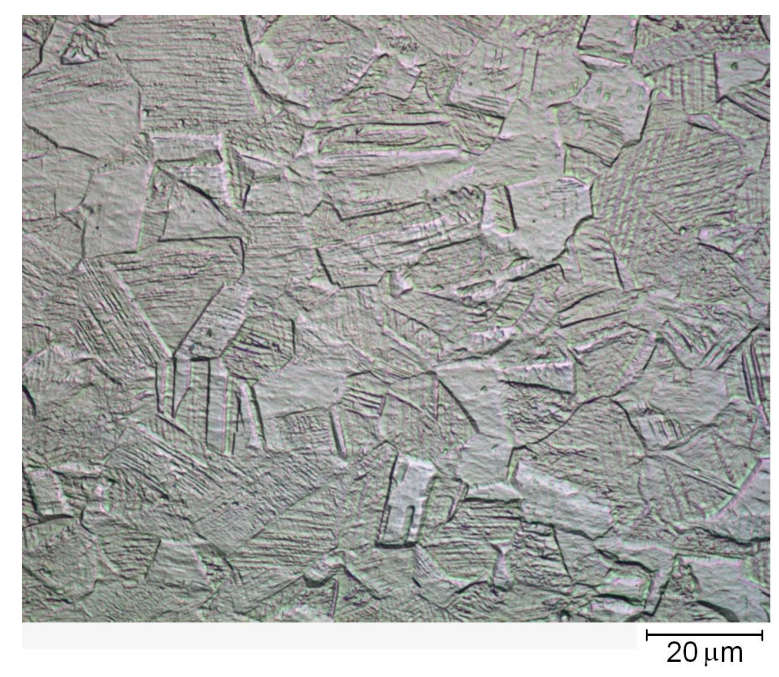

(a)

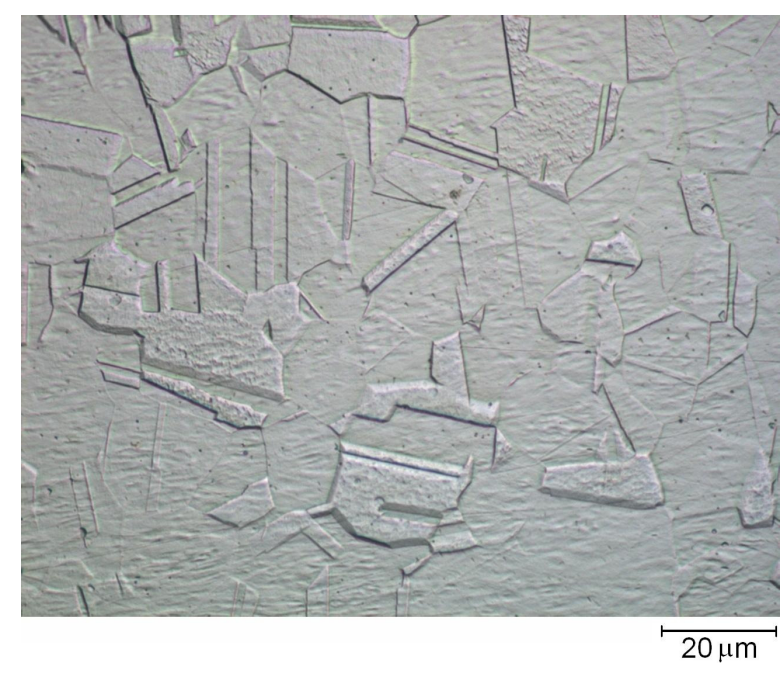

(b)

Figura 42 - Microestruturas dos aços na condição "como recebida". (a) AISI 201 e (b) AISI 304. Ataque de ácido oxálico eletrolítico. MO.

A microestrutura do aço AISI 201 é bifásica e apresenta grãos equiaxiais de austenita e plaquetas de martensita, além da presença de maclas de deformação. $\mathrm{Na}$ realidade, a martensita induzida por deformação presente no aço AISI 201 só pode ser observada com aumentos superiores aos propiciados pela microscopia óptica, utilizando-se, por exemplo, microscopia eletrônica de transmissão. Devido à similaridade de morfologia das maclas de deformação, defeito de empilhamento e martensita- $\varepsilon$ existe uma dificuldade inerente na identificação positiva das várias estruturas [68]. O uso combinado de técnicas de caracterização faz parte da interpretação da transformação de fase dos AIAs. A presença desta martensita também pode ser revelada por difração de raios $X$, que foi a técnica utilizada neste trabalho. O aço AISI 304 apresentou grãos equiaxiais monofásicos de austenita, com a presença de maclas de recozimento, sem sinal de deformação plástica. Este aço está recozido, enquanto que o aço AISI 201 apresenta sinais de 
deformação plástica. Por esta razão, amostras dos dois aços foram solubilizadas antes do início das laminações, para que os aços tivessem condição de microestrutura e dureza similares antes dos ensaios propostos.

\subsubsection{Dureza}

Os resultados de microdureza dos aços AISI 201 e AISI 304 são apresentados na tabela 11. As indentações foram realizadas na secção transversal das fitas na condição como "recebida", em amostras embutidas, após polimento. Para as medidas de microdureza foi utilizada carga de $100 \mathrm{~g}$. O resultado representa a média de cinco medidas de microdureza.

Tabela 11 - Microdureza dos aços na condição "como recebida".

\begin{tabular}{ccc}
\hline Dureza & AISI 201 & AISI 304 \\
\hline $\mathrm{HV}_{0,1}$ & $401 \pm 11$ & $166 \pm 7$ \\
\hline
\end{tabular}

A dureza do aço AISI 201 é significativamente maior que a do aço AISI 304, apresentando resultado típico de material encruado. O aço AISI 304 apresenta dureza compatível com a de um aço da série 300 solubilizado.

\subsubsection{Medidas magnéticas}

As fitas de AIA na condição "recebida" foram analisadas com ferritoscópio para determinação da porcentagem de fase ferromagnética presentes na microestrutura. Os resultados estão expressos na tabela 12. A presença de magnetismo no aço AISI 201 indica a possibilidade da presença de martensita, assim como já se suspeitava após a observação da caracterização metalográfica e a medição de dureza. O aço AISI 304 não apresentou nenhum sinal de magnetismo na condição "como recebida". 
Tabela 12 - Medidas magnéticas dos aços na condição "como recebida".

\begin{tabular}{l|cc}
\hline Medidas magnéticas & AISI 201 & AISI 304 \\
\hline Porcentagem (\%) & 4,01 & 0,01 \\
\hline
\end{tabular}

\subsubsection{Tamanho de grão}

A análise de tamanho de grão também foi realizada nos aços AISI 201 e AISI 304 e os resultados são apresentados na tabela 13. Os dois aços apresentaram granulação fina e uniforme, típica de material conformado. O aço AISI 304 apresentou tamanho de grão levemente maior que o AISI 201.

Tabela 13 - Tamanho de grão dos aços na condição "como recebida".

\begin{tabular}{ccc}
\hline Material & AISI 201 & AISI 304 \\
\hline ASTM & 9 & 8 \\
Diâmetro médio $(\square \mathrm{m})$ & 15 & 21 \\
\hline
\end{tabular}

\subsubsection{Difração de raios $\mathrm{X}$}

A análise por difração de raios $X(D R X)$ foi realizada na condição como recebida dos aços AISI 201 e AISI 304. A figura 43 apresenta os difratogramas dos dois aços e os respectivos picos relacionados à identificação de fase. Os difratogramas evidenciam a presença de martensita- $\alpha$ ' (CCC, ferromagnética) nos dois aços, mesmo com a baixa intensidade dos picos como indica a figura 43. Apesar da metalografia por MO não evidenciar a presença de martensita na microestrutura do aço AISI 304, a análise de DRX mostrou que há martensita- $\alpha$ ' no material "como recebido" identificando os picos das fases (110) $\alpha,(220) \alpha$, 
(211) $\alpha$ e (200) $\alpha$. A maior intensidade do pico da fase de austenita é diferente para cada aço, mesmo os dois aços sendo austeníticos. O aço AISI 201 apresenta maior intensidade na fase austenita (111) $\gamma$, enquanto o aço AISI 304 apresenta maior intensidade na fase austenita (220) $\gamma$. Esta diferença pode ser justificada pela textura proveniente do processo de fabricação das tiras. Vale ressaltar, que cada aço é fornecido por empresas diferentes. Uma maneira de certificar se a diferença de maior intensidade nos dois aços é causada pela textura, é fazer a análise de difração de raios $X$ dos mesmos aços na forma de pó após serem limados. No entanto, esta análise não foi realizada neste trabalho.

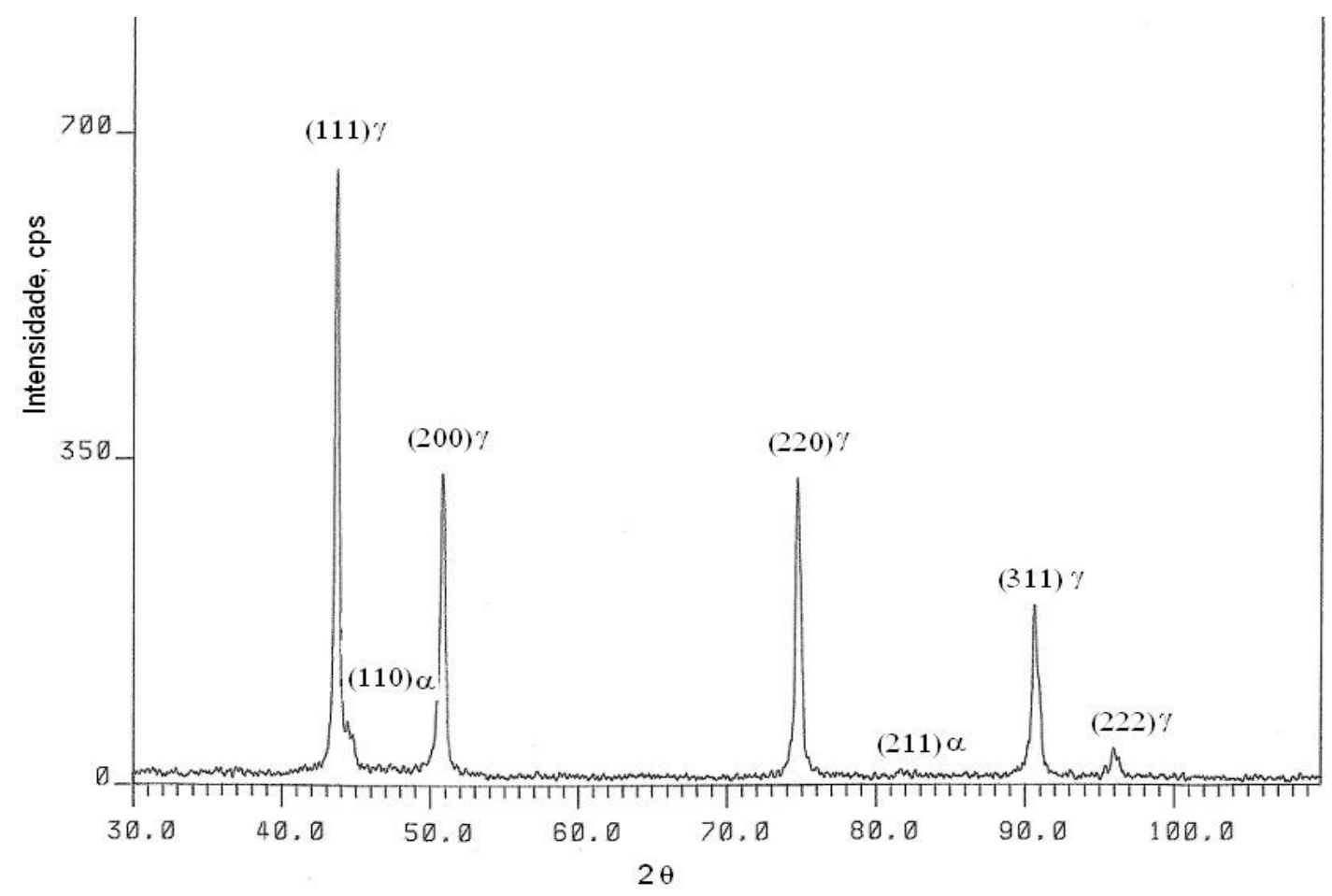

(a) 


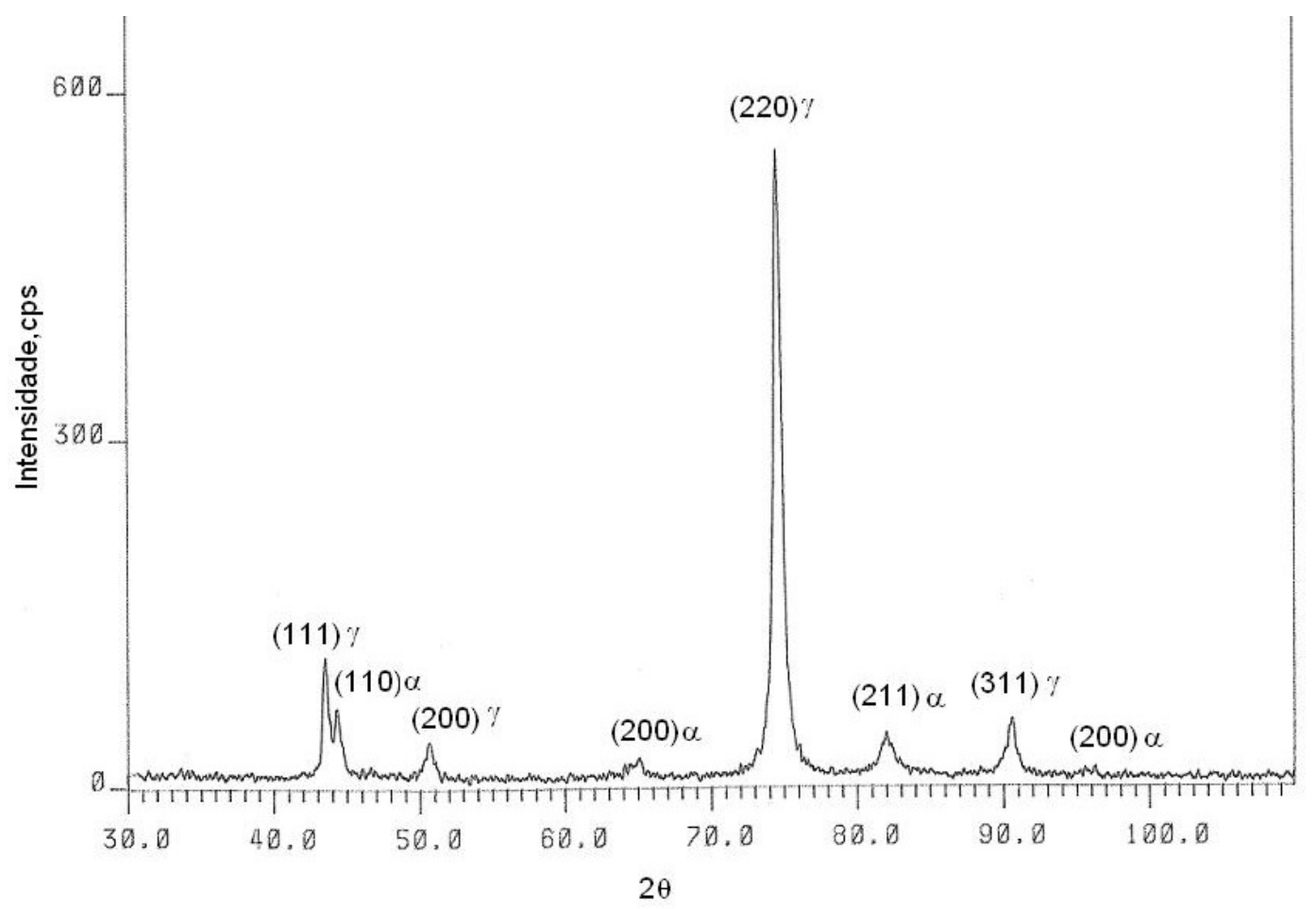

(b)

Figura 43 - Difratogramas dos aços (a) AISI 201 e (b) AISI 304. Radiação CuKo.

\subsubsection{Formação de martensitas induzidas por deformação}

Com o objetivo de avaliar a estabilidade da austenita dos aços pesquisados neste trabalho, foram calculadas as energias de defeito de empilhamento e as temperaturas $M_{s}$ e $M_{d 30}$, com auxílio de fórmulas apresentadas na revisão bibliográfica. Os resultados dos cálculos são apresentados na tabela $14 \mathrm{e}$ mostram as temperaturas $M_{s}$ e $M_{d 30}$, além da energia de defeito de empilhamento (EDE) para os casos específicos dos aços AISI 201 e 304.

Tabela 14 - Cálculo das temperaturas $M_{s} / M_{d 30 / 50}$ e da EDE dos aços AISI 201 e AISI 304.

\begin{tabular}{cccc}
\hline Cálculo & Referência & AISI 201 & AISI 304 \\
\hline $\mathrm{M}_{\mathrm{S}}\left({ }^{\circ} \mathrm{C}\right)$ & Eichelmann e Hull & $-182,6$ & $-263,3$ \\
$\mathrm{M}_{\mathrm{d} 30 / 50}\left({ }^{\circ} \mathrm{C}\right)$ & Angel & 0,56 & 7,9 \\
$\mathrm{EDE}\left(\mathrm{mJ} / \mathrm{m}^{2}\right)$ & Schramm e Reed & 3,69 & 20,46 \\
\hline
\end{tabular}


Com base nos valores calculados e apresentados na tabela 14, o aço AISI 201 é mais suscetível à transformação espontânea martensítica quando resfriado a temperatura abaixo da temperatura ambiente. Isto significa que se ambos os aços forem resfriados em nitrogênio líquido $\left(-196{ }^{\circ} \mathrm{C}\right)$, a transformação espontânea martensítica ocorrerá apenas no aço AISI 201. A mesma transformação só será observada se o aço AISI 304 for resfriado abaixo de $263^{\circ} \mathrm{C}$.

A temperatura $\mathrm{M}_{\mathrm{d} 30 / 50}$ para os aços AISI 201 e AISI 304 mostra uma situação diferente da $M_{s}$, apesar da temperatura de ambos os aços serem próximas, com diferença de apenas $7^{\circ} \mathrm{C}$. Quando o aço AISI 201 atingir a temperatura de $0{ }^{\circ} \mathrm{C}, 50 \%$ da martensita- $\alpha$ ' será produzida após $30 \%$ de deformação; a mesma ocorrência deve acontecer com o aço AISI 304 quando este atingir a temperatura de $7{ }^{\circ} \mathrm{C}$.

A energia de defeito de empilhamento calculada mostra que a EDE do aço AISI 201 é expressivamente menor que a do aço AISI 304. Isso sugere que o aço da série 200 é mais susceptível a formação de martensita induzida por deformação, conforme indica a figura 44. O valor calculado da EDE para o aço AISI 304 está de acordo com o valor encontrado na literatura descrito na revisão bibliográfica. Os dois valores de EDE para os aços AISI 201 e AISI 304 calculados neste trabalho, foram inseridos na figura 44 para melhor entendimento e discussão comparativamente a outros AIAs. Os materiais de baixa EDE apresentam maior densidade de discordâncias, maior energia armazenada na deformação, maior uniformidade no arranjo das discordâncias e maior propensão a formação de martensita induzida por deformação [37]. 


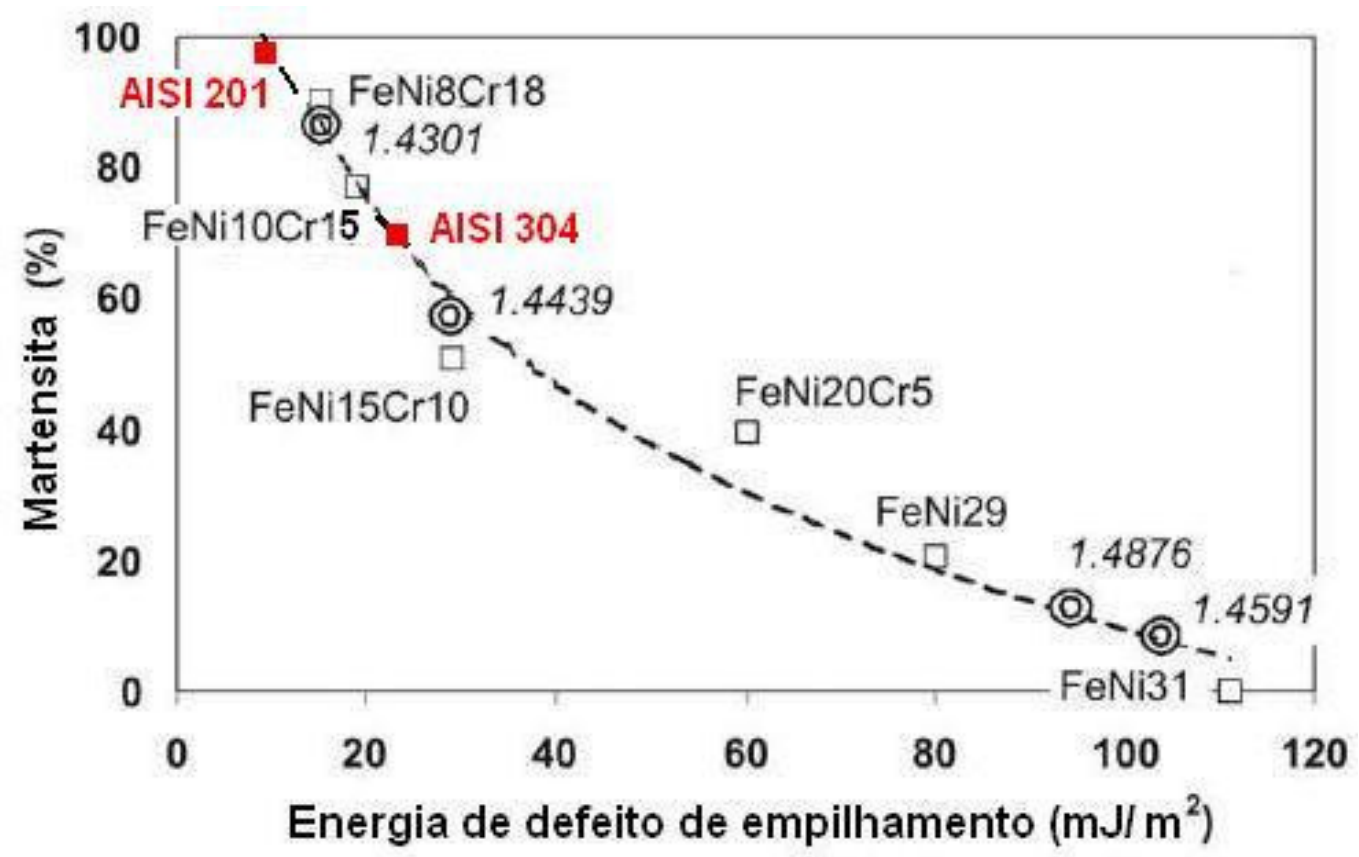

Figura 44 - Correlação entre martensita induzida por deformação e a EDE. Adaptado de [38].

Por meio da equação de proposta por Scharamm e Reed [40], foi possível obter os valores de EDE para os aços selecionados para este trabalho. Da mesma forma, os valores calculados de EDE mostraram-se coerentes aos encontrados na literatura. A figura 44 comprova que o aço AISI 201 possui maior susceptibilidade na transformação de fase induzida por deformação quando comparado com outros AIAs da série 300 e a quantidade da fração de martensita formada também tende a ser superior.

\subsubsection{Ensaios eletroquímicos utilizados neste trabalho}

Neste estudo foram utilizados os métodos eletroquímicos mais convencionais adotados na literatura [55, 98, 100,117-119], como os ensaios de espectroscopia de impedância eletroquímica (EIE) e a polarização potenciodinâmica anódica com o objetivo de avaliar a resistência à corrosão e o comportamento à repassivação, respectivamente. 


\subsubsection{Espectroscopia de Impedância Eletroquímica (EIE)}

A comparação dos dois aços quanto à resistência à corrosão foi feita após 24 $\mathrm{h}$ de imersão em uma solução salina tamponada com fosfato (Phosphate buffered saline solution - PBS), à temperatura de $25^{\circ} \mathrm{C}$ e naturalmente aerada, simulando a composição dos fluidos fisiológicos. Os gráficos representativos dos diagramas de Bode (módulo de impedância), ângulo de fase e Nyquist para as tiras de AIA AISI 201 e AISI 304, na condição "como recebida", são apresentados na figura 45.

Ambos os materiais analisados apresentaram valores próximos de módulo de impedância, da ordem de $10^{5} \Omega . \mathrm{cm}^{2}$, na freqüência de $0,01 \mathrm{~Hz}$, como indica o diagrama de Bode na figura 45 (a).

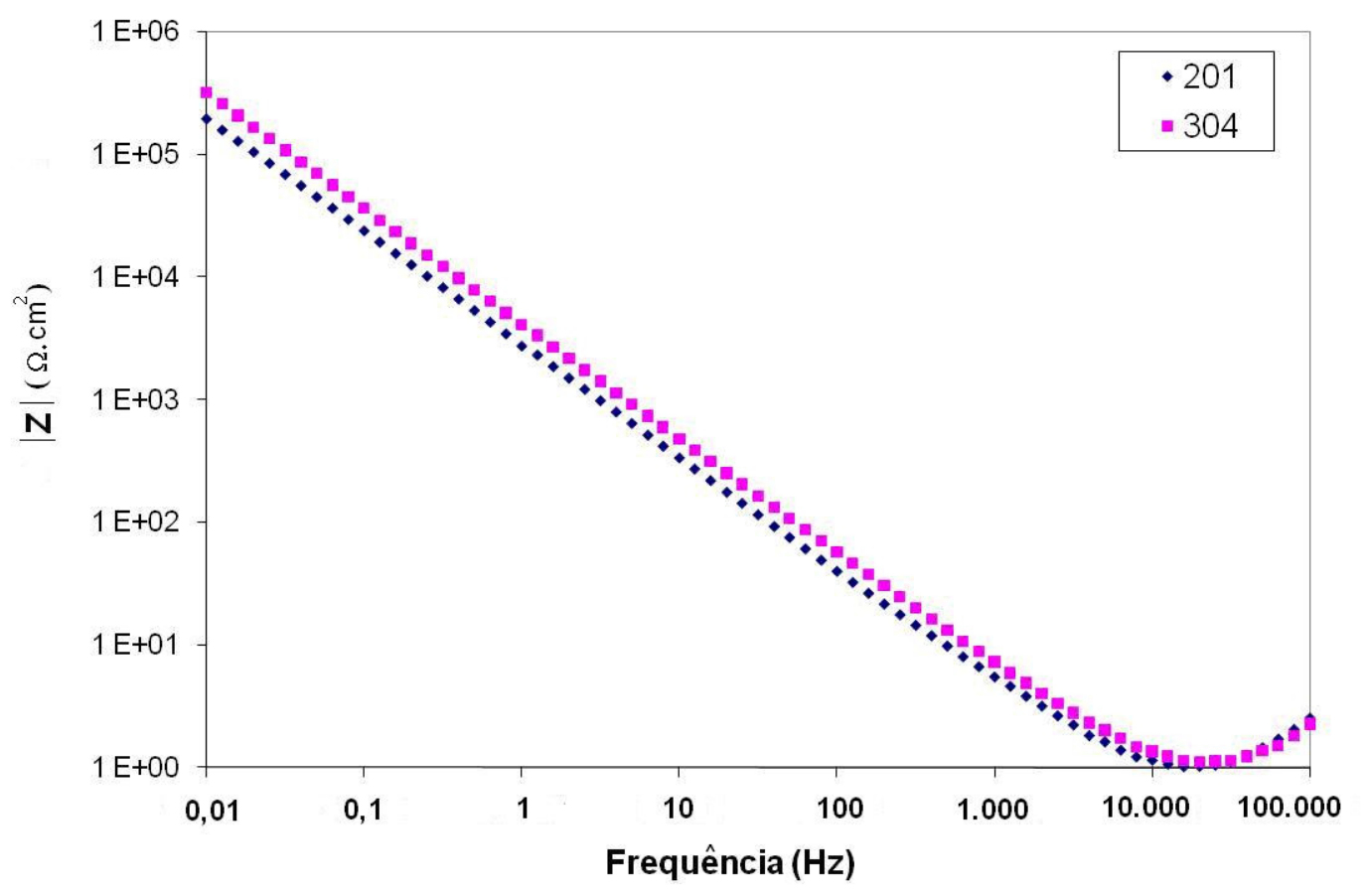

(a) 


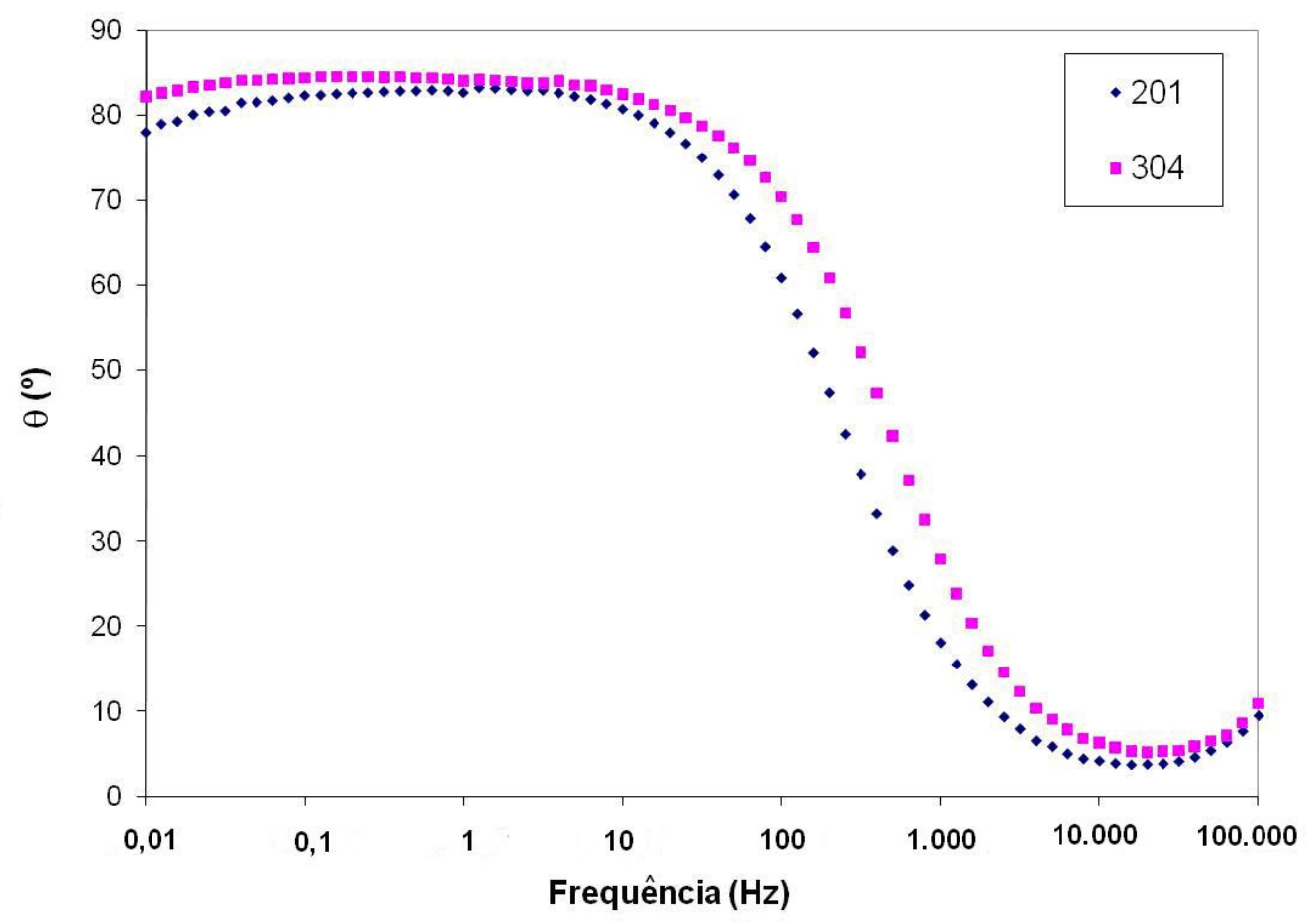

(b)

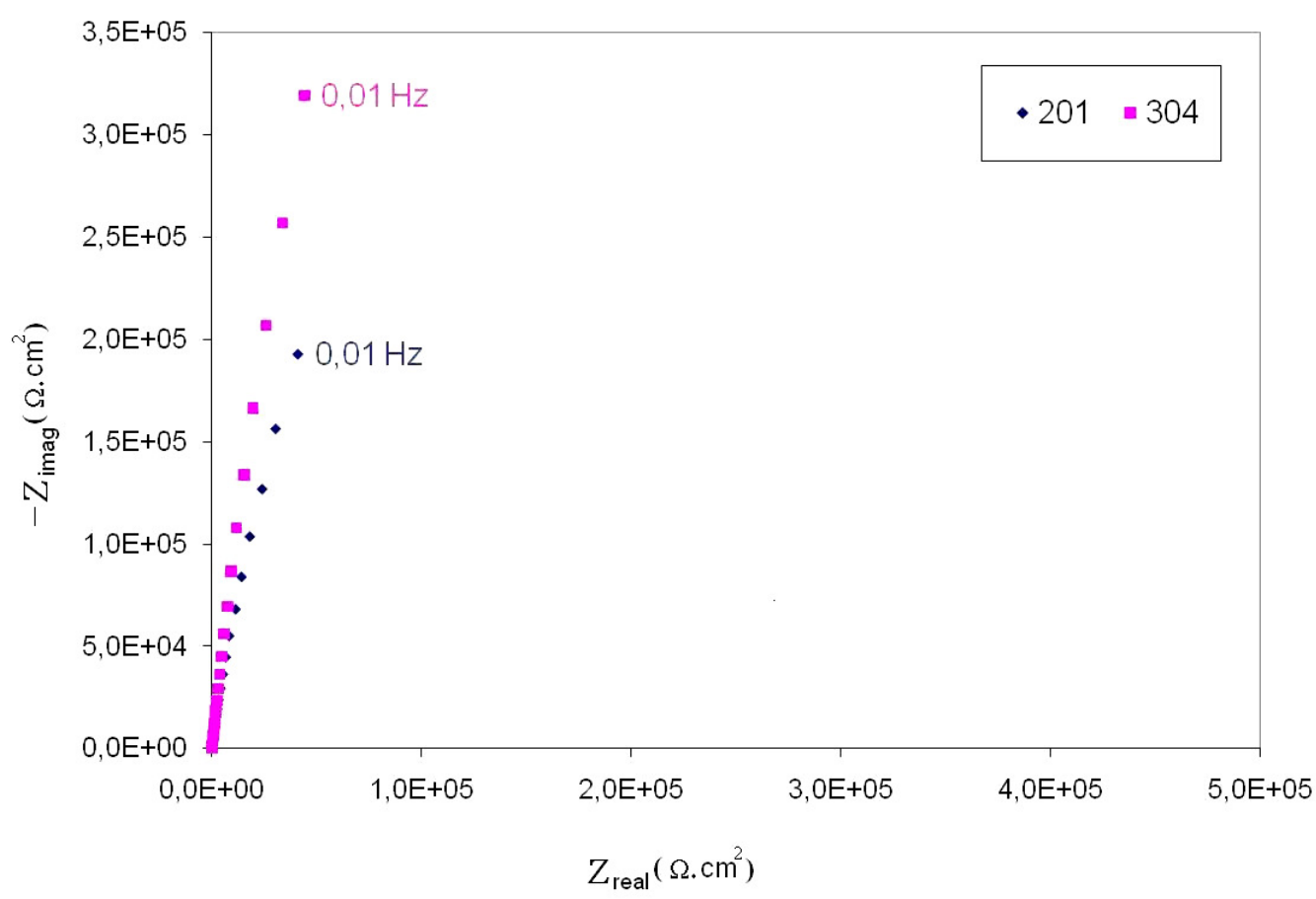

(c)

Figura 45 - Diagramas de espectroscopia de impedância eletroquímica dos aços inoxidáveis AISI 201 e AISI 304: a) Bode ou módulo de impedância Z, b) ângulo de fase - após 24 horas de imersão em solução PBS a $25^{\circ} \mathrm{C}$ e c) Nyquist.

O extenso platô observado nas regiões de média a baixas freqüências do diagrama de ângulo de fase (figura 45 (b)), com ângulos de fase em torno de -80 
sugere a existência de duas constantes de tempo sobrepostas para os dois materiais, sendo aquela a freqüências mais altas, provavelmente associada a processos de transferência de carga e, aquela em menores freqüências, ao substrato exposto na base dos poros/defeitos do óxido passivante. Em ambos os casos, não há uma nítida separação das constantes de tempo e o aço AISI 304 revela um comportamento ligeiramente mais capacitivo que o aço AISI 201 em freqüências mais baixas, apesar do aspecto similar das duas curvas no diagramas de ângulo de fase. Este resultado é registrado na literatura para aços inoxidáveis e eletrodo de ferro passivo [98, 123]. Portanto, para ambos os aços, os resultados indicam um comportamento capacitivo, típico de materiais passivos, na faixa de média a baixas freqüências (entre $10 \mathrm{~Hz}$ a 0,01 Hz), com ângulos de fase próximos a $-80^{\circ}$, indicando uma película passiva de alta estabilidade e com elevada resistência à corrosão [124]. Tal resultado deve ser associado à película de óxido passivante de caráter duplex formado sobre os AIAs.

Terada [55] realizou ensaios similares em outros três AIAs em sua tese de doutorado utilizando três soluções distintas: solução de Hanks, um meio de cultura celular MEM (mininum essential medium). Os aços W.Nr. 14575 e W. Nr. 1.4460 alto $\mathrm{N}$ solubilizado também apresentaram um extenso platô na mesma ordem de grandeza de ângulo de fase observado nas regiões de baixas freqüências do diagrama de bode, mostrando comportamento similar aos aços AISI 201 e AISI 304. No entanto, o aço AISI 316L apresentou comportamento distinto no trabalho de Terada [55]. O aço comercial mais adotado para fabricação de implantes mostrou a presença nítida de duas constantes de tempo, bem separadas. A primeira constante associada ao pico em cerca de $100 \mathrm{~Hz}$ e a segunda relacionada a pico em freqüências menores que $0,1 \mathrm{~Hz}$. Antunes [122] também trabalhou com o aço AISI $316 \mathrm{~L}$ e obteve um resultado diferente do trabalho de Terada [55]. Antunes [122] realizou ensaio de EIE em aço AISI 316L sem tratamento de passivação e sem revestimento imerso em solução de Hanks. O diagrama de Bode apresentou um comportamento capacitivo com valores de ângulo de fase próximos a -80 na região de baixa frequência. Este comportamento é típico de metais passivos e similar aos aços AISI 201 e AISI 304. Fato similar também é descrito por Assis [120] para diferentes ligas de titânio que foram estudadas em sua tese com as soluções de $0,9 \%$ de $\mathrm{NaCl}$, solução de Hanks e meio de cultura MEM. Os diagramas de Bode são característicos pos duas regiões distintas: (a) região de alta freqüência (1 kHz a 
$100 \mathrm{kHz}$ ), onde 0 módulo de $Z$ é praticamente constante e o ângulo de fase é próximo de $0^{\circ}$. Esta é uma característica associada com o comportamento resistivo à solução; (b) região de baixa e média freqüências em que o diagrama de módulo de Z apresenta uma inclinação de cerca de -1 e o ângulo de fase se aproxima de $90^{\circ}$. Esses diagramas sugerem um comportamento altamente capacitivo, típico de filme altamente protetor e com elevada resistência à corrosão para as ligas de Ti. diagrama de Nyquist (figura 45(c)) indica impedância ligeiramente superior em baixas freqüências para o aço AISI 304 em comparação ao aço AISI 201. Os resultados de EIE indicam mecanismos similares para os dois tipos de aço nas condições de ensaio adotadas.

Os resultados dos ensaios de EIE sugerem que a camada passiva sobre os aços AISI 201 e AISI 304 possuem regiões de propriedades distintas, representadas pelas duas constantes de tempo que se sobrepõem no diagrama de Bode. Ambos os AlAs apresentam comportamentos similares quanto à resistência à corrosão. No entanto, o aço AISI 304 possui valores de capacitância e de impedância superiores aos do aço AISI 201.

Muitos autores $[55,100,122,125]$ sugerem que a camada passiva dos Als é constituída por uma camada duplex, na qual o óxido mais interno é rico em cromo e o óxido mais externo é rico em ferro e níquel. A presença de duas constantes de tempo, indicadas pelos resultados das curvas no diagrama de Bode dos aços AISI 201 e AISI 304 estão de acordo com a literatura.

\subsubsection{Polarização potenciodinâmica anódica}

As curvas de polarização potenciodinâmica para os dois materiais aços podem ser vistas na figura 46. Os potenciais de corrosão para os aços AISI 201 e AISI 304 são de aproximadamente $-100 \mathrm{mV}_{\mathrm{ECS}}$ e $-175 \mathrm{mV}_{\mathrm{ECS}}$, ou seja, o aço AISI 201 apresenta potencial de corrosão mais elevado que o aço AISI 304. A densidade de corrente de corrosão dos dois materiais foi estimada pela extrapolação da curva catódica para o potencial de corrosão e os valores obtidos da ordem de $10^{-8} \mathrm{~A} / \mathrm{cm}^{2}$ são típicos de materiais passivos, indicando a formação de uma camada de óxido protetor na superfície dos aços no meio de ensaio. A tendência à formação de pites já era evidente na curva do aço AISI 304 a partir de $+240 m V_{E C S}$, justificada pelas regiões de instabilidade características da quebra e repassivação da película de 
óxido passiva. Da mesma forma, Antunes [122] descreve em seu trabalho que o aço AISI 316L também apresenta região de instabilidade característica da quebra e repassivação da película que se estende de $+179 \mathrm{mV}_{\mathrm{ECS}} \mathrm{a}+614 \mathrm{mV}_{\mathrm{ECS}}$, quando ocorre um aumento mais acentuado da densidade de corrente, indicando a quebra da passividade do aço e a formação de pites. Os potenciais de quebra da película passiva dos aços AISI 304 e AISI 201 são bem definidos e seus valores foram de aproximadamente $300 \mathrm{mV}_{\mathrm{ECS}}$ e $355 \mathrm{mV}_{\mathrm{ECS}}$, respectivamente, indicando maior susceptibilidade à corrosão localizada do primeiro.

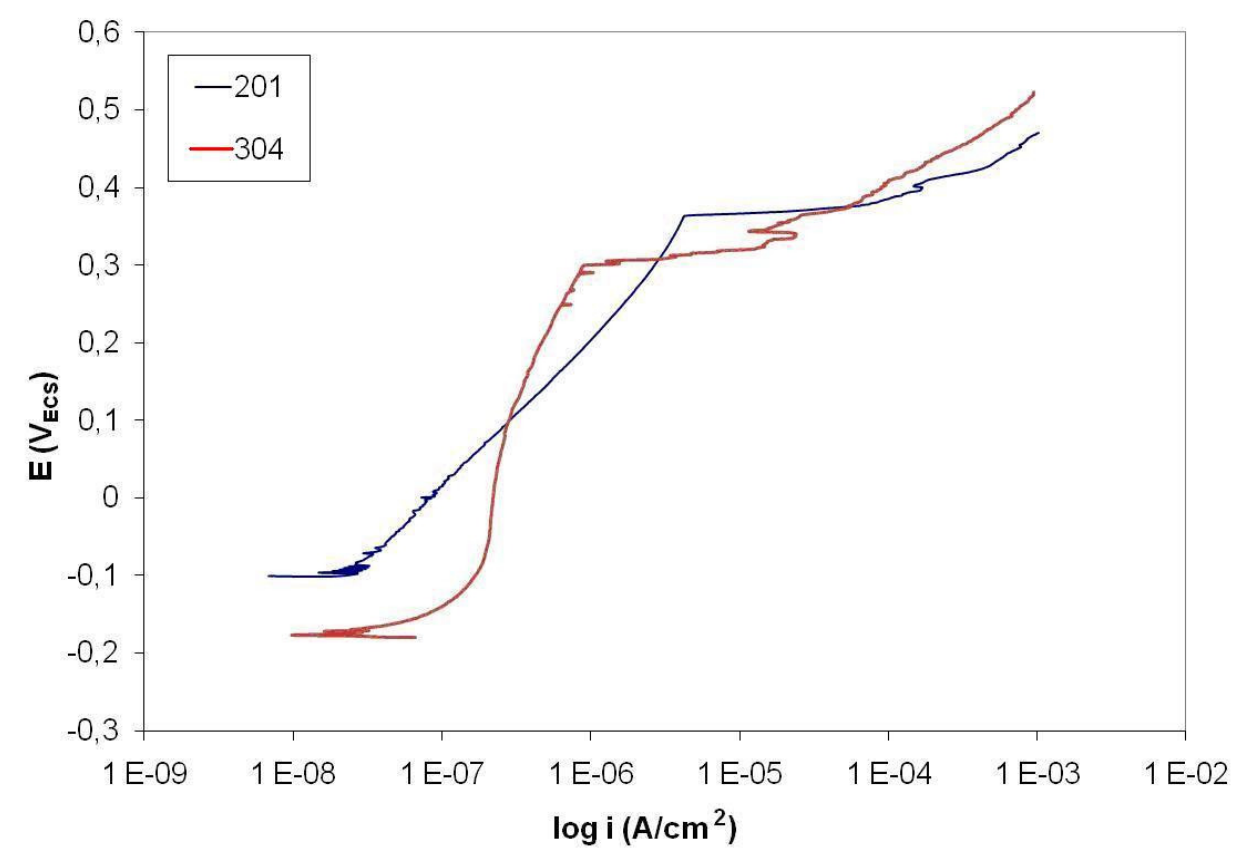

Figura 46 - Diagramas de polarização potenciodinâmica dos aços inoxidáveis AISI 201 e AISI 304 após $24 \mathrm{~h}$ de imersão em solução PBS a $25^{\circ} \mathrm{C}$.

As amostras ensaiadas foram analisadas em MEV após o ensaio de polarização potenciodinâmica e as micrografias registradas podem ser vistas nas figuras 47 e 48. A análise mostrou que não houve presença de pites no aço inoxidável AISI 201. No entanto, pôde ser observada uma corrosão localizada relacionada às estrias causadas pelo processo prévio de laminação da amostra do aço AISI 201, conforme indica a figura 47 (b). 


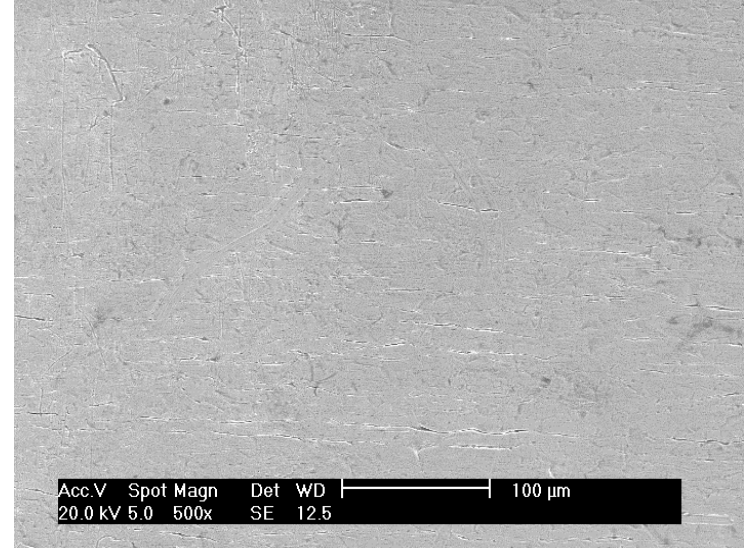

(a)

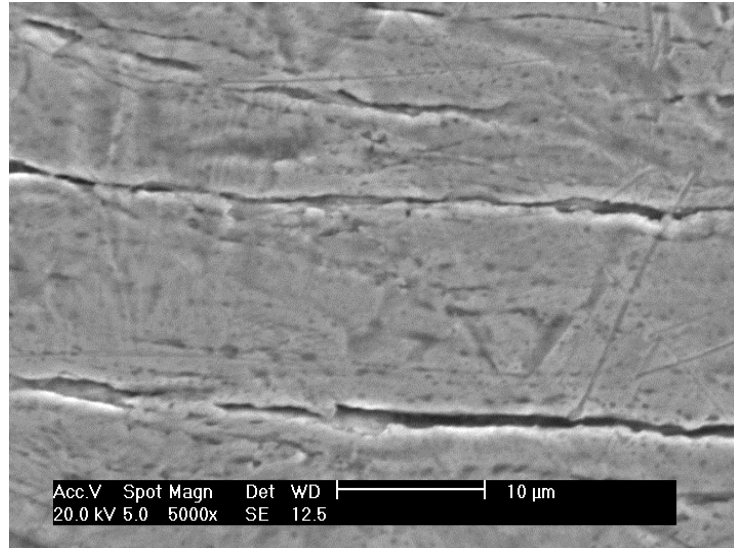

(b)

Figura 47 - Micrografias do aço inoxidável AISI 201 após polarização potenciodinâmica. Corrosão localizada. MEV. Imagem de elétrons secundários. (a) 500x de ampliação e (b) 5.000x de ampliação.

As micrografias revelam ainda a existência de corrosão por pite no aço AISI 304, sendo estes de diâmetro aproximado de $100 \square \mathrm{m}$, com bordas irregulares e profundas.

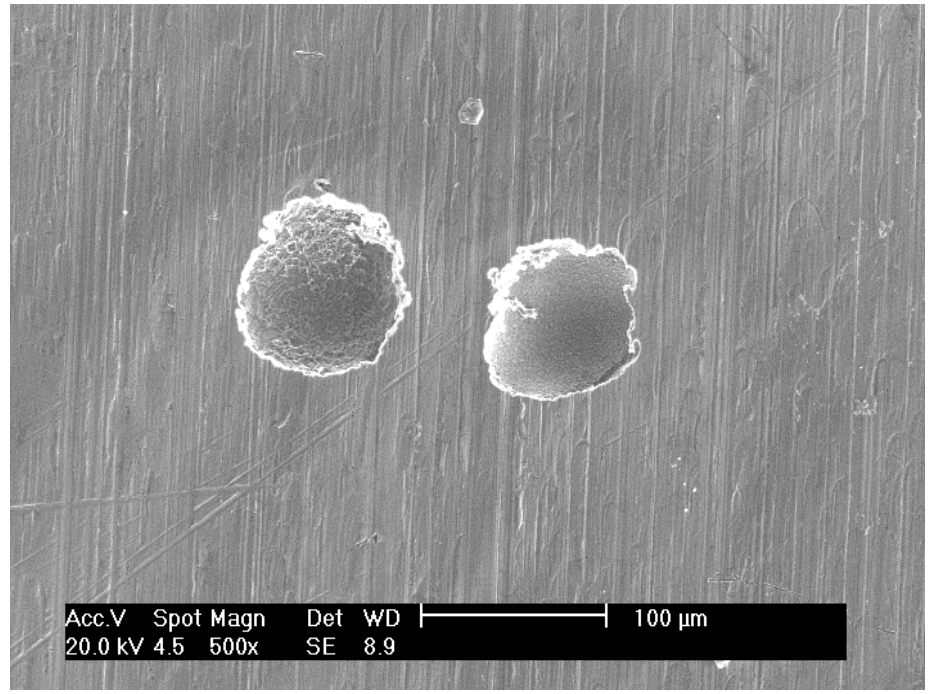

Figura 48 - Micrografia do aço inoxidável AISI 304 após polarização potenciodinâmica. Corrosão por pite. MEV. Imagem de elétrons secundários. 500x de ampliação.

Os valores de resistência equivalente por pite (PRE) foram calculados para os aços AISI 201 e AISI 304 de acordo com a equação 9 descrita na revisão bibliográfica. A tabela 15 indica os resultados deste cálculo comparativamente a outros AIAs [55]. De acordo com os resultados de PRE, o aço AISI 201 possui o menor valor de resistência à corrosão por pite, muito provavelmente devido ao seu reduzido teor de cromo e níquel na composição. Terada [55] calculou os valores de PRE para outros AIAs e comprovou que o aço AISI 316L possui resistência por pite 
um pouco superior ao aço AISI 304. De forma geral, apesar de haver uma pequena diferença de PRE entre os aços AISI 201, AISI 304, AISI 316L e W.Nr 1.4970, todos apresentaram o PRE na mesma ordem de grandeza, de 16 a 25. O único aço que apresentou um valor de PRE distinto dos demais listados abaixo foi o W.Nr. 1.4460. De forma crescente, a ordem em relação à resistência à corrosão de acordo com o cálculo do PRE é a seguinte: AISI 201 < W.Nr. 1.4970 < AISI 304 < AISI 24,40 < W.Nr. 1.4460 .

Tabela 15 - Resistência equivalente por pite (PRE) dos AIAs.

\begin{tabular}{cccccc}
\hline Materiais & AISI & AISI & AISI & W.Nr. & $\begin{array}{c}\text { W. Nr. } \\
\mathbf{1 . 4 4 6 0} \\
\end{array}$ \\
& $\mathbf{2 0 1}$ & $\mathbf{3 0 4}$ & $\mathbf{3 1 6 L}$ & $\mathbf{1 . 4 9 7 0}$ & $\mathbf{0 , 8 7 \% \mathrm { N } )}$ \\
\hline PRE & 16,08 & 22,77 & 24,40 & 18,73 & 57,47 \\
\hline
\end{tabular}

No entanto, não foi possível correlacionar os valores de PRE com os potenciais de quebra de filme passivo obtidos por meio do ensaio de polarização potenciodinâmica anódica. A mesma impossibilidade de correlação foi descrita por Terada [55]. Provavelmente a diferença de comportamento está relacionada à microestrutura do material, que não é levada em conta no cálculo do PRE. Apesar de o cálculo teórico do PRE identificar o aço AISI 304 como sendo mais resistente à corrosão por pite do que o aço AISI 201, a análise após ensaio por MEV juntamente com o ensaio de polarização, identificou corrosão por pite no aço AISI 304, mesmo considerando que ambos os aços foram testados em condições similares. O resultado prático obtido pelo ensaio de polarização potenciodinâmica anódica confirma o consenso da literatura [97,103-105] que afirma que a adição de nitrogênio melhora a resistência à corrosão por pite, reduz a taxa de corrosão e facilita a repassivação tornando o filme de óxido mais estável.

\subsection{Material solubilizado}

O tratamento de solubilização foi realizado para que os aços tivessem condição de microestrutura e dureza similares, típicas de aço recozido. 


\subsubsection{Caracterização metalográfica}

As tiras dos aços AISI 201 e AISI 304 foram solubilizadas a $1050{ }^{\circ} \mathrm{C}$ por 10 minutos em forno tubular e atmosfera inerte de argônio, seguidas de resfriamento em água. As secções transversais das fitas de AIAs AISI 201 e AISI 304 foram caracterizadas em MO. As respectivas microestruturas estão ilustradas nas figuras 49.

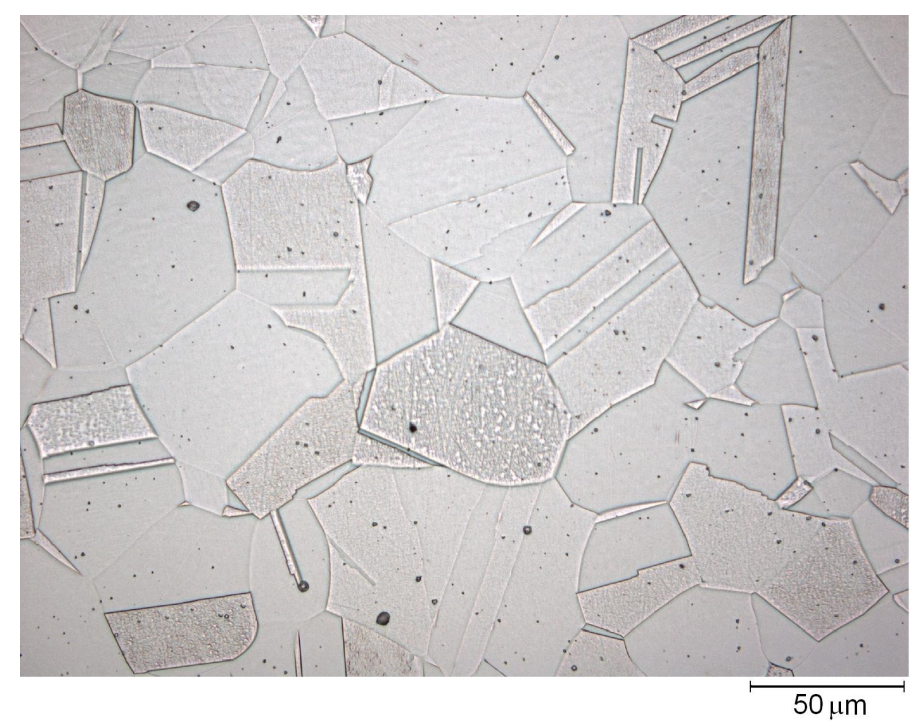

(a)

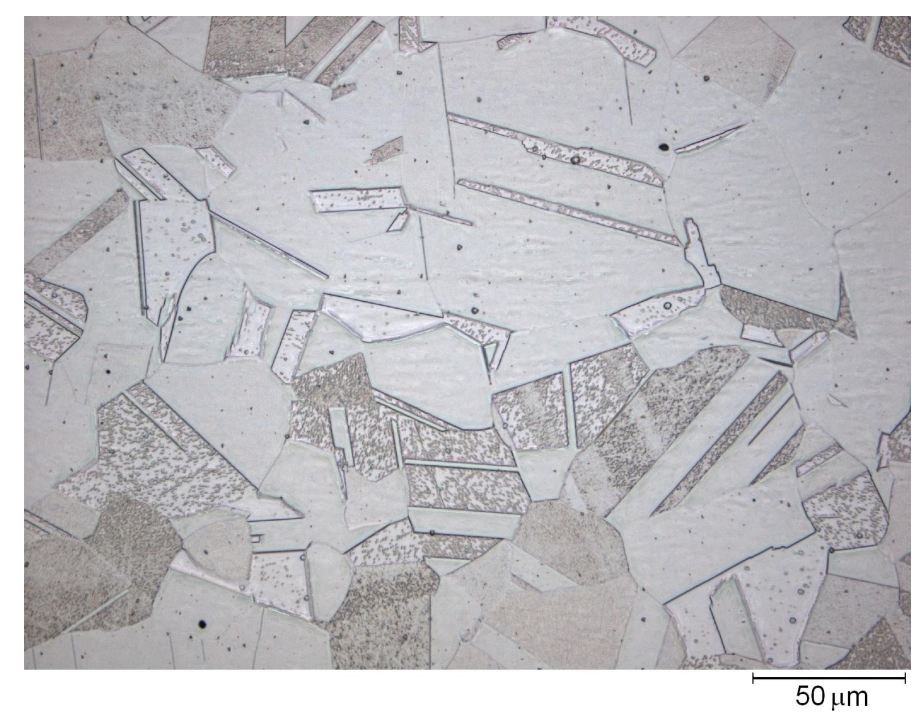

(b)

Figura 49 - Microestruturas dos aços na condição solubilizada. (a) AISI 201 e (b) AISI 304. Ataque de ácido oxálico eletrolítico. MO. 
Os aços AISI 201 e AISI 304 solubilizados apresentaram microestruturas semelhantes, formadas por grãos equiaxiais monofásicos de austenita, com a presença de maclas de recozimento e sem sinal de deformação plástica. Aparentemente, o tratamento térmico de solubilização mostrou-se eficaz, pois não foi observada fase martensítica na análise de $\mathrm{MO}$, conforme a figura 42 . No entanto, as análises complementares de dureza e medidas magnéticas serão necessárias para confirmar a presença de martensita. A análise de tamanho de grão foi realizada nos aços AISI 201 e AISI 304 na condição solubilizada e os resultados são apresentados na tabela 16. Os dois aços apresentaram grãos grosseiros e uniformes, o que comprova que houve crescimento de grão durante o tratamento de solubilização, apesar do pouco tempo de tratamento térmico. O aço AISI 304 apresentou tamanho de grão levemente maior que o AISI 201.

Tabela 16 - Análise do tamanho de grão dos aços solubilizados.

\begin{tabular}{ccc}
\hline Material & AISI 201 & AISI 304 \\
\hline ASTM & 6 & 5 \\
Diâmetro médio $(\mu \mathrm{m})$ & 40 & 60 \\
\hline
\end{tabular}

Como complementação da análise de MEV, a análise semi-quantitativa de espectroscopia de elétrons por energia dispersiva (EDS) foi realizada para análise de área da matriz dos aços. Os resultados estão descritos na figura 50, (a) para o aço AISI 201 e (b) para o aço AISI 304. A intensidade dos picos de manganês e níquel difere de um material para o outro, sendo que para o aço AISI 201 os picos de níquel apresentam-se em menor intensidade e o pico de manganês está mais evidente que no material AISI 304. 


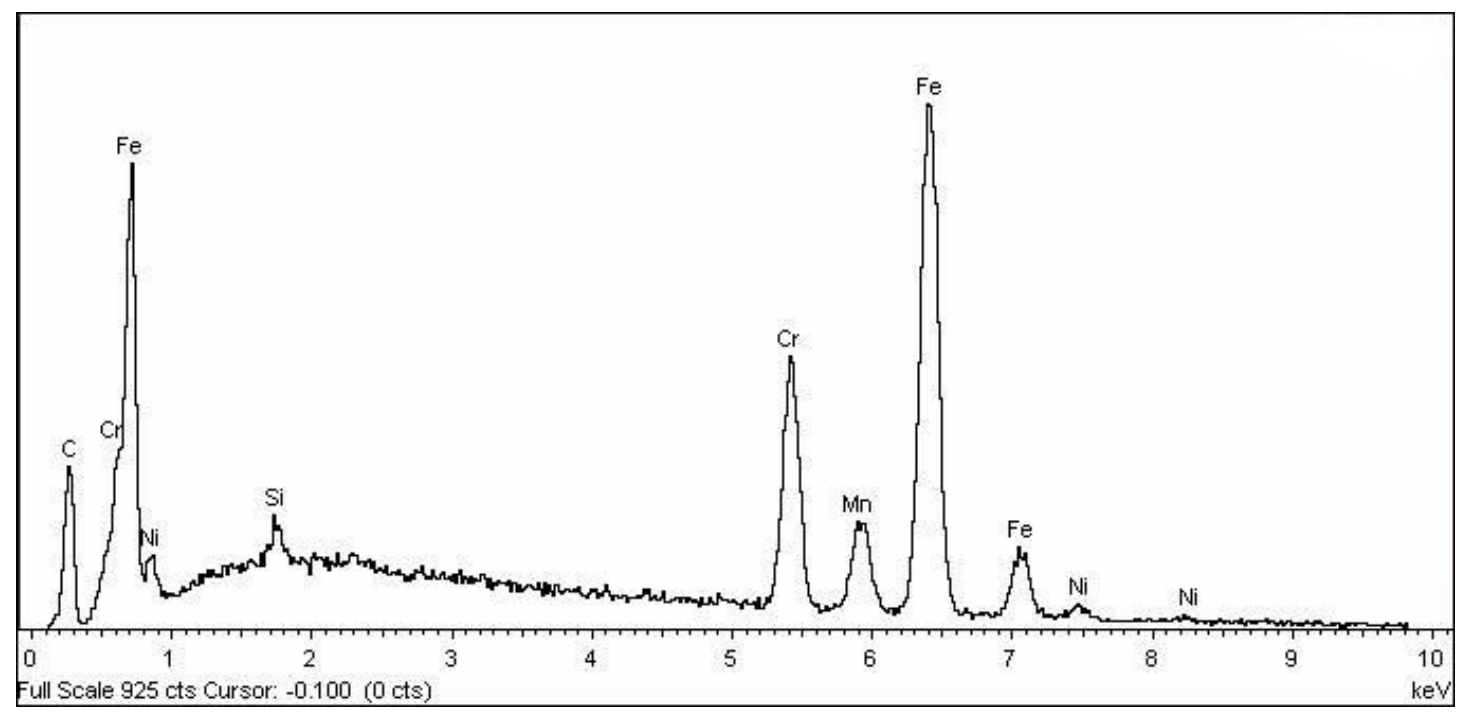

(a)

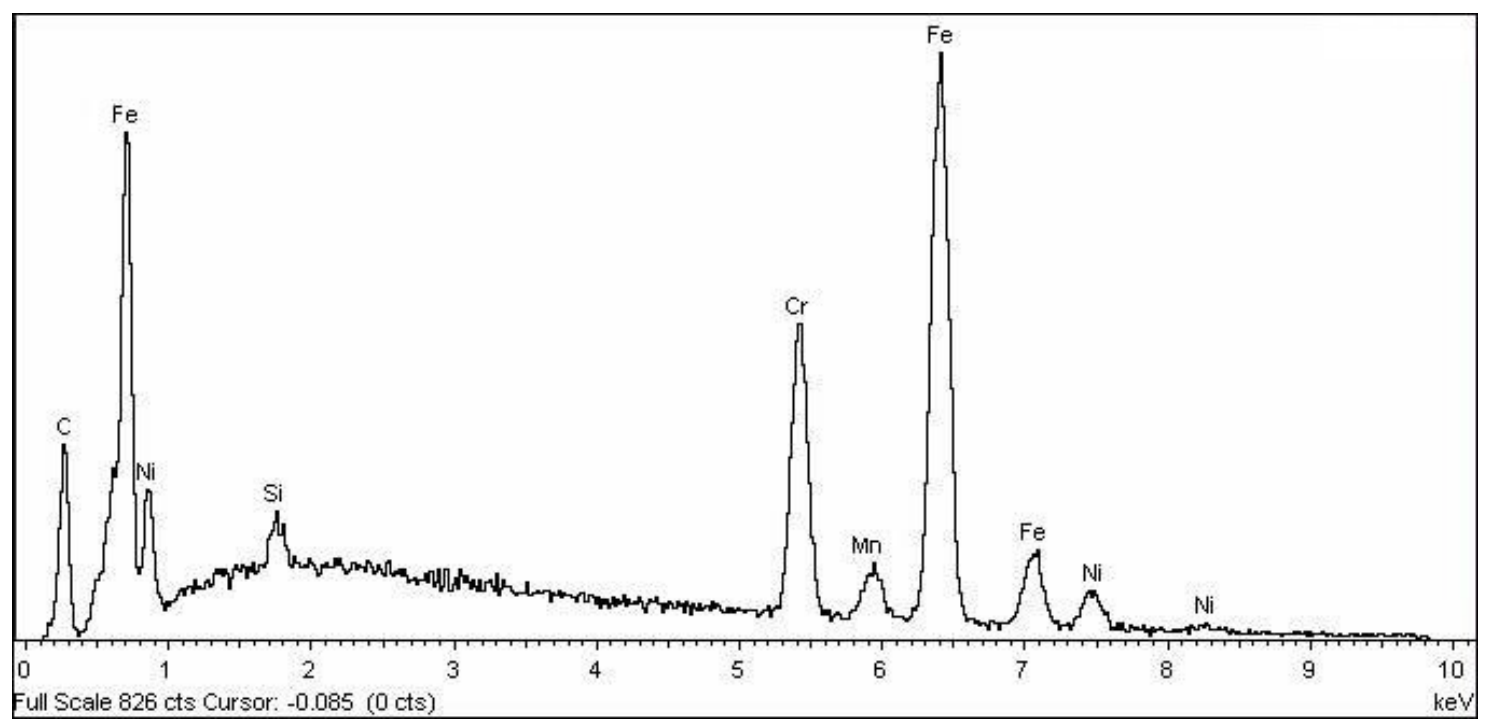

(b)

Figura 50 - Análise de energia dispersiva (EDS) da matriz dos aços solubilizados (a) AISI 201 e (b) AISI 304.

\subsubsection{Dureza}

Os resultados de microdureza dos aços AISI 201 e AISI 304 são apresentados na tabela 17. As indentações foram realizadas na secção transversal das fitas solubilizadas, em amostras embutidas e após polimento. A carga estabelecida para medição de microdureza foi de $100 \mathrm{~g}$. Os resultados indicados na tabela 13 representam a média de cinco medidas de microdureza. 
Tabela 17 - Microdureza dos aços solubilizados.

\begin{tabular}{ccc}
\hline Dureza & AISI 201 & AISI 304 \\
\hline $\mathrm{HV}_{0,1}$ & $220 \pm 12$ & $170 \pm 7$ \\
\hline
\end{tabular}

Com a finalidade de aumentar a estabilidade da austenita devido à menor quantidade de níquel no aço AISI 201, o teor de nitrogênio é duas vezes maior do que no aço AISI 304. Esta maior quantidade de nitrogênio na composição do aço AISI 201provoca o aumento da resistência devido ao endurecimento por solução sólida dos solutos intersticiais [46, 48], e conseqüentemente, espera-se que o material apresente maior dureza como foi detectado. Apesar de haver uma diferença de 50 pontos entre os aços solubilizados, ambos apresentaram dureza típica de material recozido. A medição de microdureza do aço solubilizado AISI 201 apresentou diminuição significativa quando comparado ao material na condição "como recebida", com diferença de 180HV. O valor de microdureza do aço AISI 304 manteve-se constante quando comparado à condição "como recebida".

\subsubsection{Medidas magnéticas}

Amostras dos aços solubilizados foram analisadas com auxílio do ferritoscópio para determinação da porcentagem de fase ferromagnética presente na microestrutura. Os aços AISI 201 e AISI 304 não apresentaram nenhum sinal de magnetismo na condição solubilizada, conforme descrição dos resultados descritos na tabela 18. A ausência de magnetismo no aço AISI 201 evidencia que o tratamento térmico de solubilização mostrou-se eficaz, juntamente com a confirmação das análises de metalografia e microdureza.

Tabela 18 - Medidas magnéticas dos aços solubilizados

\begin{tabular}{c|cc}
\hline Medidas magnéticas & AISI 201 & AISI 304 \\
\hline Porcentagem (\%) & 0,01 & 0,01 \\
\hline
\end{tabular}




\subsubsection{Difração de raios $X$}

A análise de DRX foi realizada nas tiras dos aços AISI 201 e AISI 304 após a solubilização. A figura 51 apresenta os difratogramas dos dois aços e suas respectivas identificações de fase. Os difratogramas evidenciam uma microestrutura completamente austenítica nos aços AISI 201 e AISI 304 comprovando a eficácia do tratamento de solubilização, juntamente aos resultados de dureza e caracterização metalográfica.

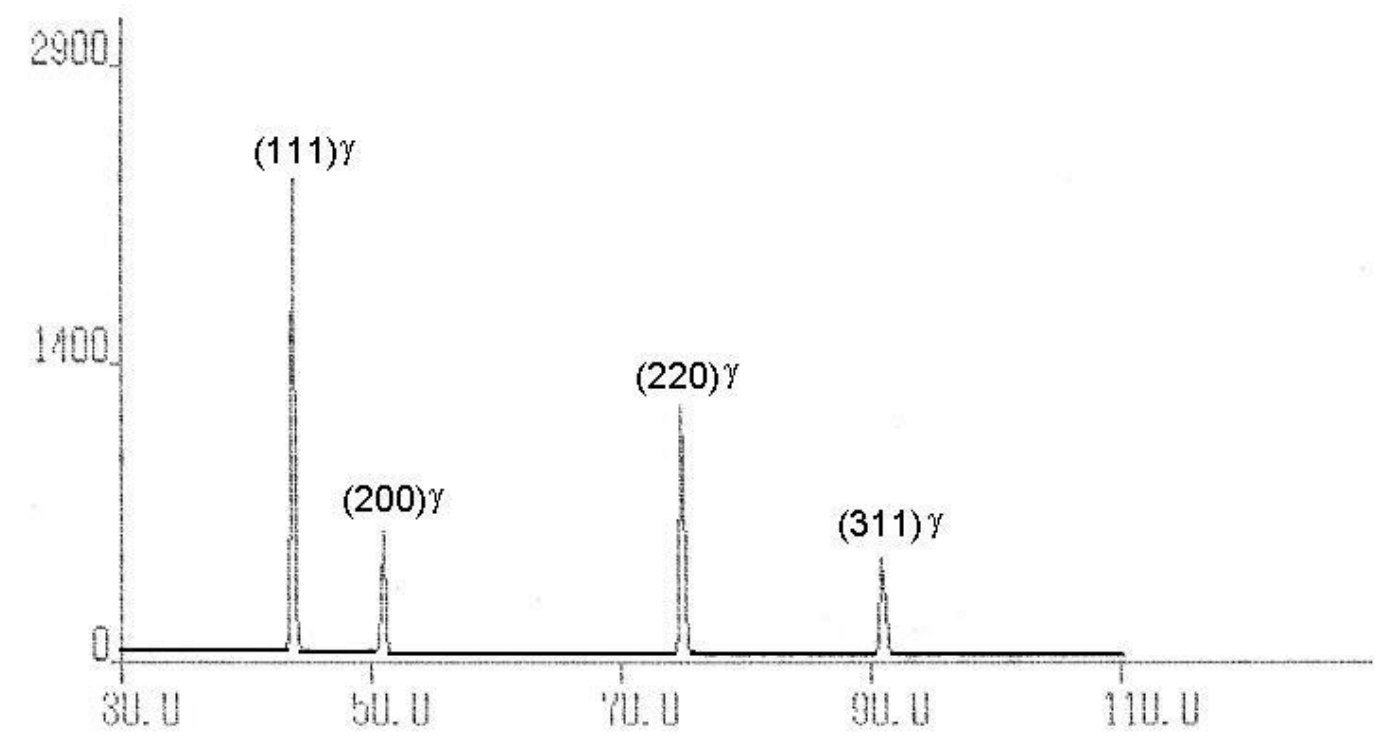

(a)

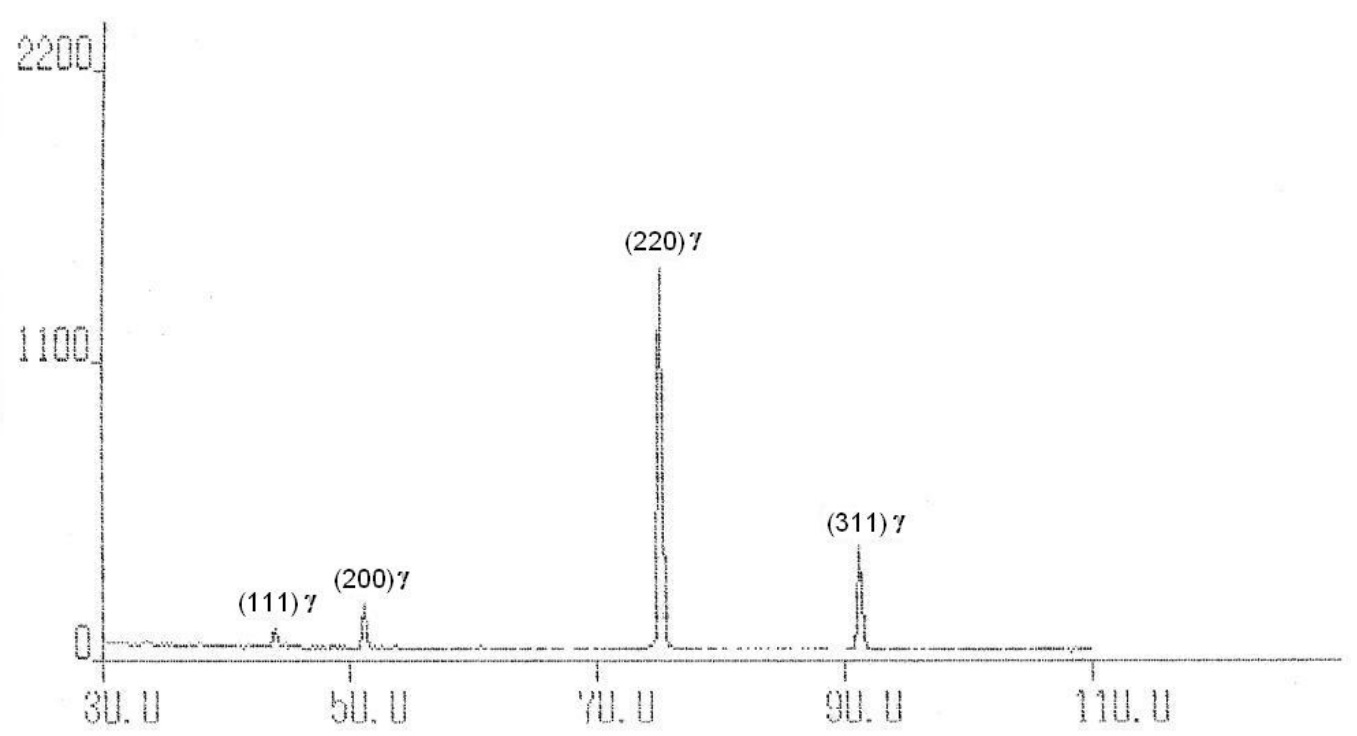

(b)

Figura 51 - Difratogramas dos aços solubilizados (a) AISI 201 e (b) AISI 304. Radiação CuKa. 
Conforme foi avaliado, os aços solubilizados apresentam microestrutura completamente austenítica. No entanto, houve diferença dos picos da austenita de

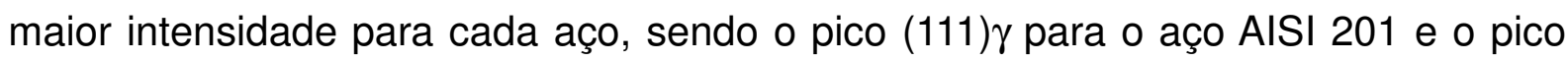
(220) y para o aço AISI 304. A diferença da maior intensidade dos picos de austenita entre os aços AISI 201 e AISI 304 provavelmente está relacionada à textura proveniente do processo de laminação para fabricação das tiras.

\subsubsection{Resfriamento sub-zero}

De forma a testar experimentalmente os valores de Ms calculados pela equação de Eichmann e Hull [28] na tabela 14, tiras solubilizadas dos aços AIAs foram expostas a temperatura criogênica para avaliar se a transformação espontânea martensítica ocorreria apenas no aço AISI 201 como foi previsto. Amostras dos aços solubilizados AISI 201 e AISI 304 foram mergulhadas em nitrogênio líquido (cerca de $-196^{\circ} \mathrm{C}$ ) por 20 minutos cada, com movimento circular para cada amostra a fim de evitar a formação de camada de calor na superfície da amostra. A figura 52 ilustra as microestruturas das tiras de aço AISI 2013 AISI 304 após resfriamento sub-zero.

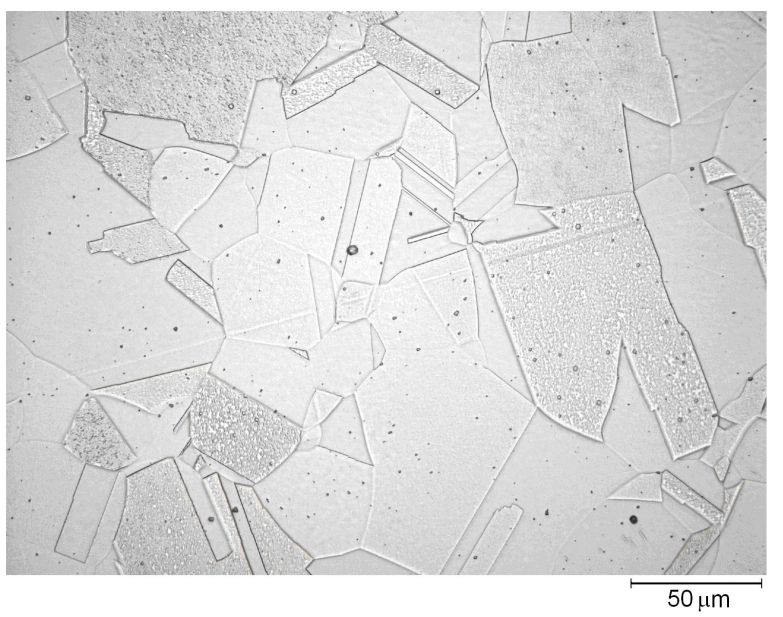

(a)

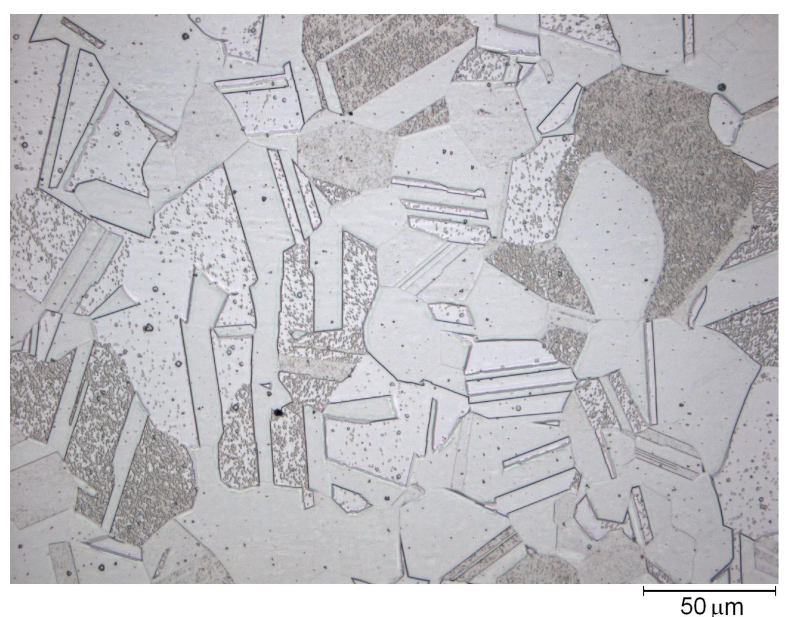

(b)

Figura 52 - Microestruturas dos aços após resfriamento em nitrogênio líquido a -196 ${ }^{\circ} \mathrm{C}$. (a) AISI 201 e (b) AISI 304. Ataque de ácido oxálico eletrolítico. MO.

A microestrutura dos dois materiais apresenta aspectos similares entre si e similares com a condição solubilizada formada por grãos equiaxiais monofásicos de 
austenita, com a presença de maclas de recozimento e sem sinal de deformação plástica. A tabela 19, a seguir, mostra os valores de dureza das amostras após o tratamento sub-zero. Esses valores representam a média de cinco medições ao longo da secção metalográfica.

Tabela 19 - Microdureza dos aços solubilizados após resfriamento sub-zero.

\begin{tabular}{ccc}
\hline Dureza & AISI 201 & AISI 304 \\
\hline $\mathrm{HV}_{0,1}$ & $223 \pm 7$ & $168 \pm 4$ \\
\hline
\end{tabular}

Não houve alteração dos valores de dureza antes e após o resfriamento em nitrogênio líquido. A alteração da dureza seria o principal parâmetro para avaliação da transformação espontânea martensítica pelo resfriamento.

Amostras dos aços resfriados em nitrogênio líquido foram analisadas com auxílio do ferritoscópio para determinação da porcentagem de fase ferromagnética presentes na microestrutura. Não foi detectada fase magnética nessas amostras, conforme descrição dos resultados na tabela 20. Os valores expressos na tabela representam a média de 10 pontos medidos ao longo da superfície da tira.

Tabela 20 - Medidas magnéticas dos aços solubilizados após resfriamento sub-zero.

\begin{tabular}{c|cc}
\hline Medidas magnéticas & AISI 201 & AISI 304 \\
\hline Porcentagem (\%) & 0,01 & 0,01 \\
\hline
\end{tabular}

Ao contrário do que foi previsto por meio do cálculo da temperatura $M_{s}$ descrito na tabela 14 , não foi observada nenhuma evidência da ocorrência da transformação martensítica espontânea por meio do resfriamento sub-zero como a equação 3 para o cálculo de $M_{s}$ previa para o aço AISI 201. A equação proposta por Eichelman e Hull [28] deve ser estimada apenas como referência e a experiência com resfriamento sub-zero comprovou que o cálculo teórico não pode ser considerado absoluto. 


\subsection{Material laminado}

Os testes de laminação foram realizados em um laminador duplo de laboratório, sem uso de lubrificação e a temperatura ambiente (cerca de $25^{\circ} \mathrm{C}$ ). $\mathrm{O}$ diâmetro dos cilindros de trabalho era de $190 \mathrm{~mm}$ cada. A velocidade de laminação adotada foi de $10 \mathrm{~mm} / \mathrm{min}$ e as tiras foram sempre laminadas no mesmo sentido. Durante a laminação, a espessura das amostras foi controlada com auxílio de um micrômetro digital. Com o laminador utilizado, só foi possível garantir a espessura das tiras até a casa centesimal, conforme descrito na tabela 21.

Tabela 21 - Espessura das tiras dos aços AISI 201 e AISI 304 após laminação.

\begin{tabular}{ccc}
\hline Redução & AISI 201 & AISI 304 \\
\hline $5 \%$ & $0,437 \pm 0,004$ & $0,399 \pm 0,004$ \\
$10 \%$ & $0,414 \pm 0,004$ & $0,378 \pm 0,002$ \\
$15 \%$ & $0,391 \pm 0,003$ & $0,357 \pm 0,003$ \\
$20 \%$ & $0,368 \pm 0,005$ & $0,336 \pm 0,003$ \\
$25 \%$ & $0,345 \pm 0,003$ & $0,315 \pm 0,005$ \\
$30 \%$ & $0,322 \pm 0,004$ & $0,294 \pm 0,003$ \\
\hline
\end{tabular}

\subsubsection{Caracterização metalográfica}

As tiras dos aços AISI 201 e AISI 304 laminadas foram caracterizadas por meio de microscopia óptica (MO), conforme figura 53 e 54, respectivamente. A figura 55 mostra a progressão das microestruturas do aço AISI 201 a partir de pequenas deformações em $5 \%$ (figura 53 (a)) até a redução máxima adotada neste trabalho de 30\% (figura 53 (f)) por meio de ataque metalográfico de ácido oxálico eletrolítico. Após ataque metalográfico é possível visualizar a austenita como a fase clara e a martensita como a fase escura na forma de agulhas finas, conforme a figura 42 . Para a amostra com deformação muito baixa (figura 53 (a)), não foi observada a presença de martensita por meio de MO. 


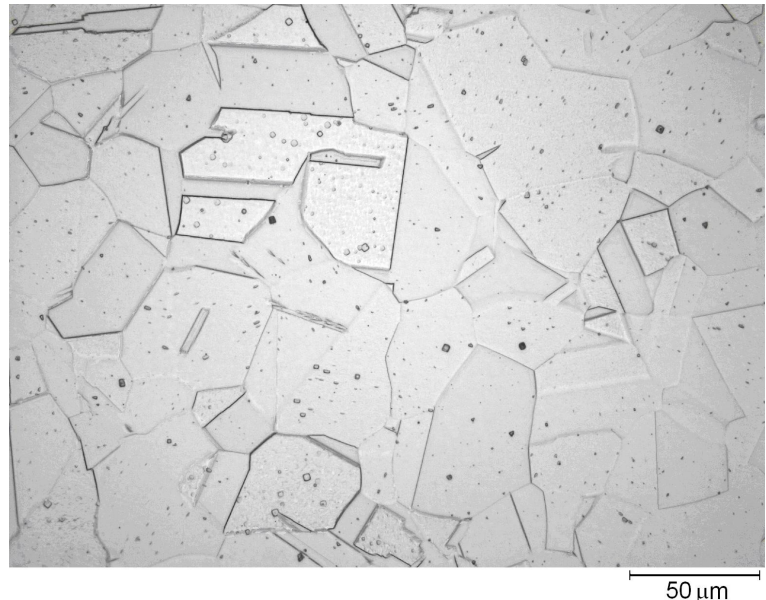

(a)

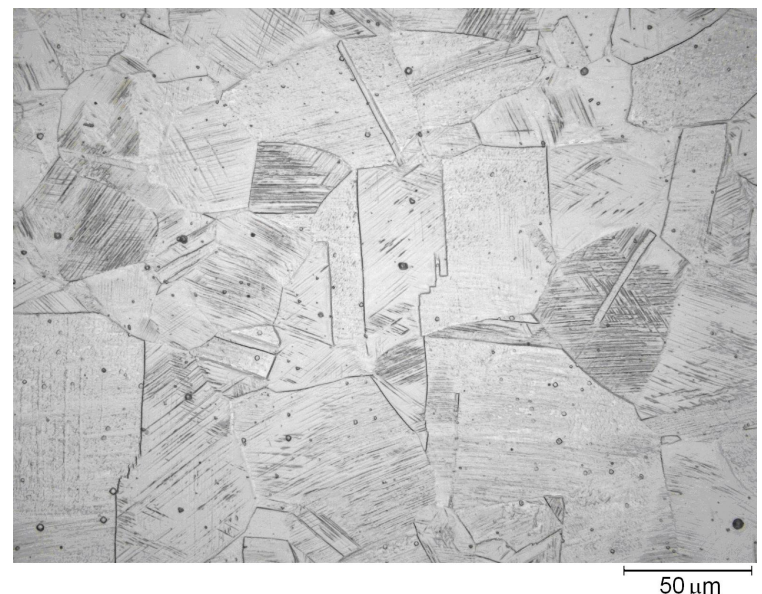

(c)

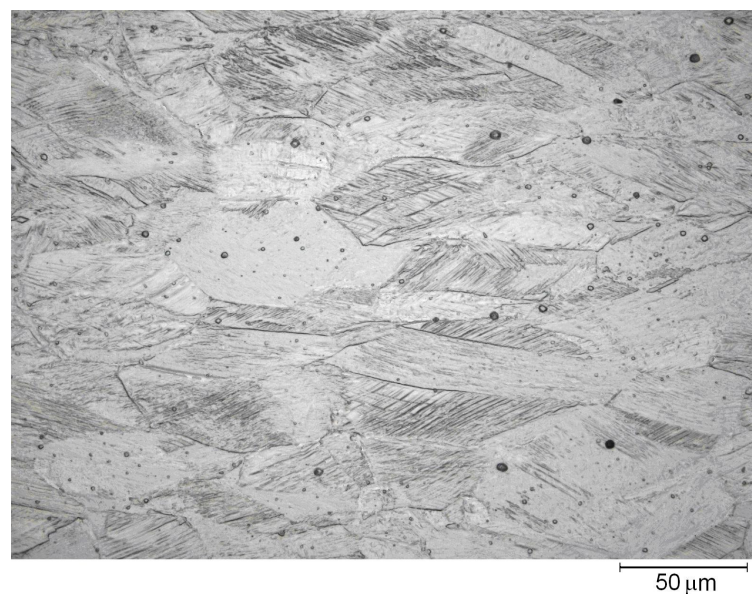

(e)

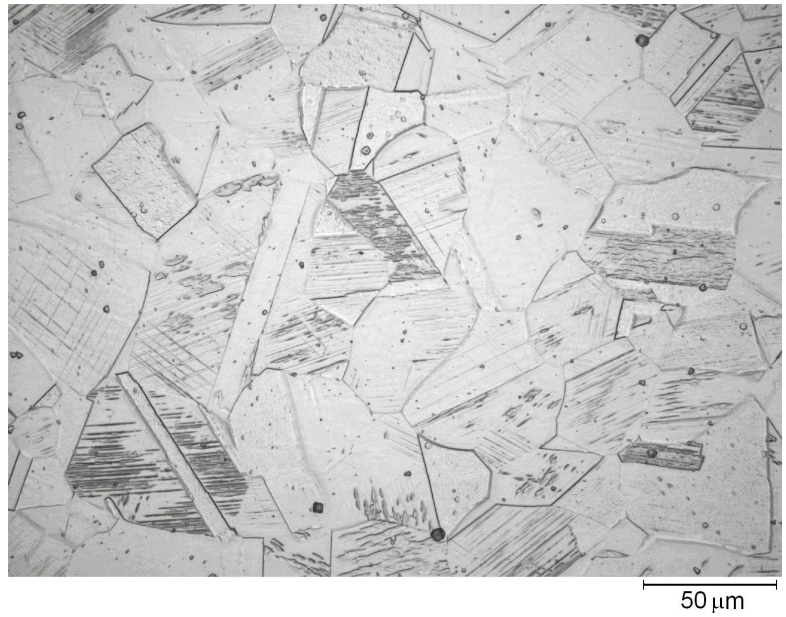

(b)

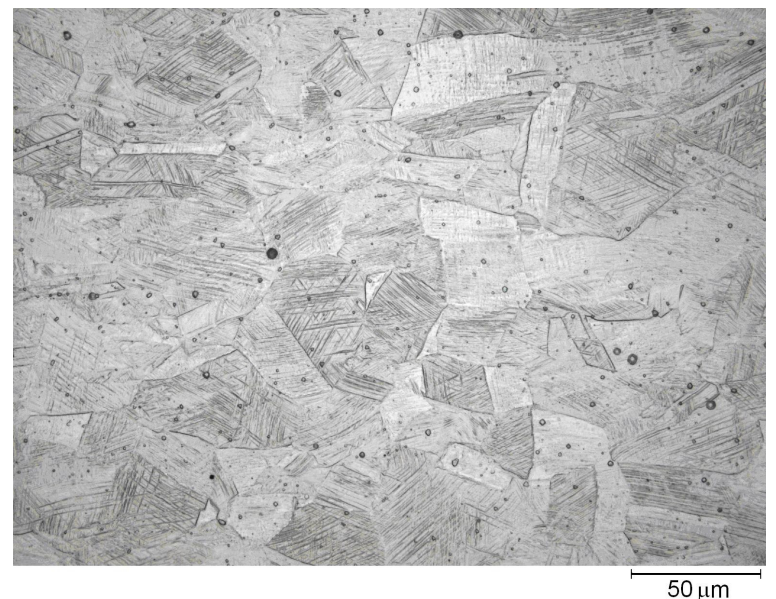

(d)

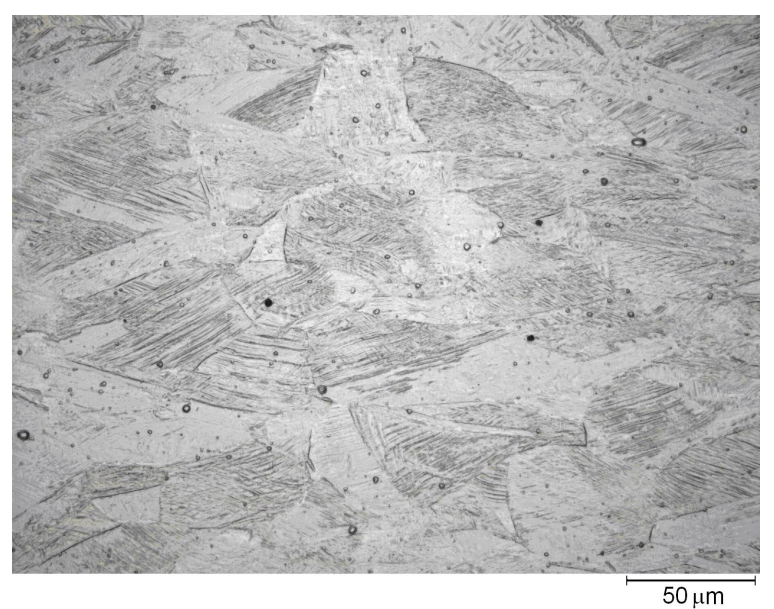

(f)

Figura 53 - Microestruturas representativas do aço AISI 201 laminado em diferentes graus de redução: (a) $5 \%$, (b) $10 \%$, (c) $15 \%$, (d) $20 \%$, (e) $25 \%$, (f) $30 \%$. Ataque em ácido oxálico eletrolítico. MO. Ampliação de 500x. 


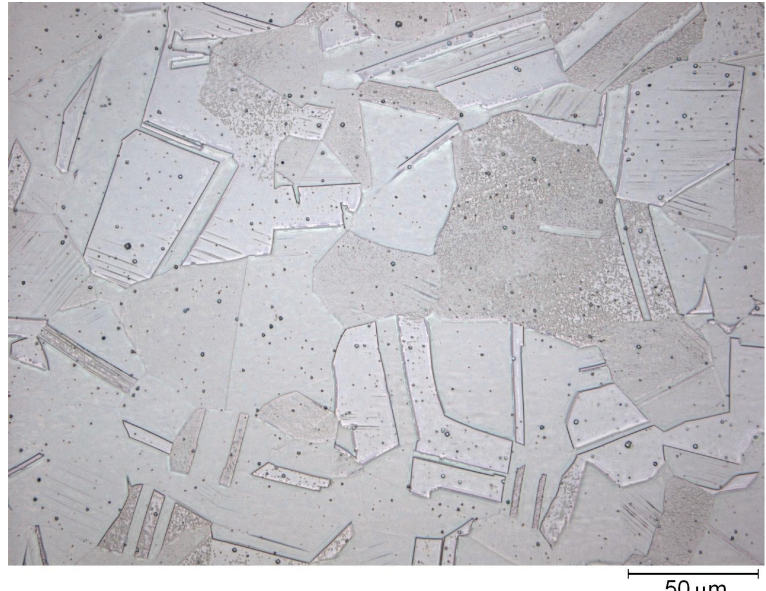

(a)

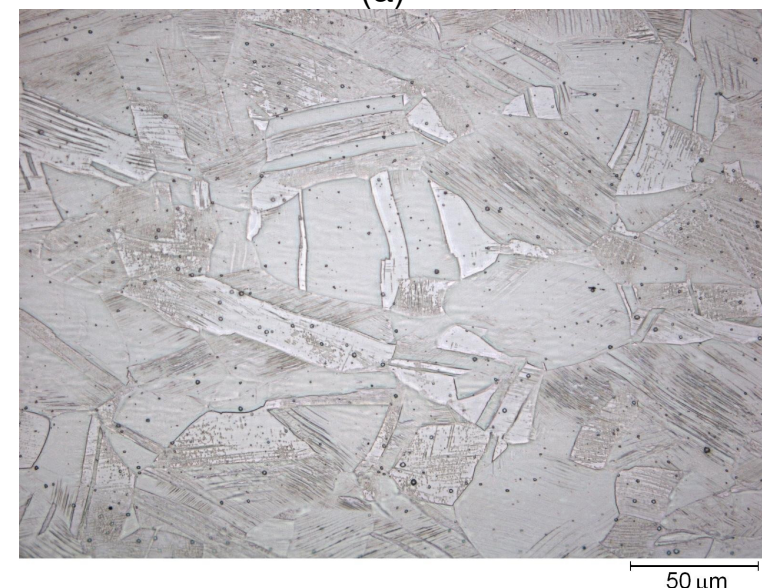

(c)

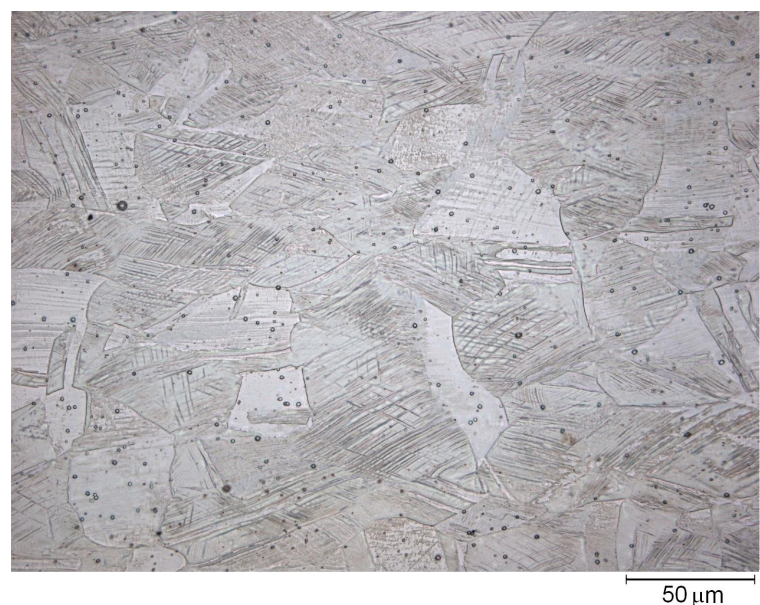

(e)

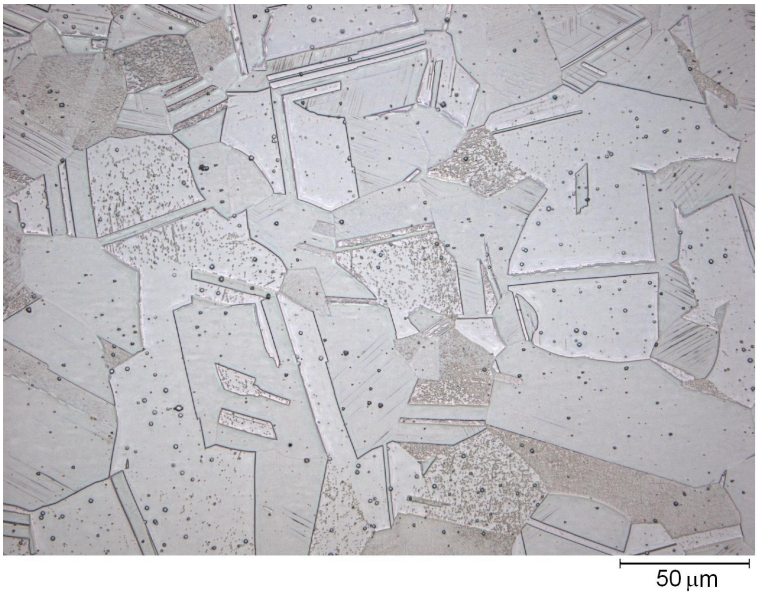

(b)

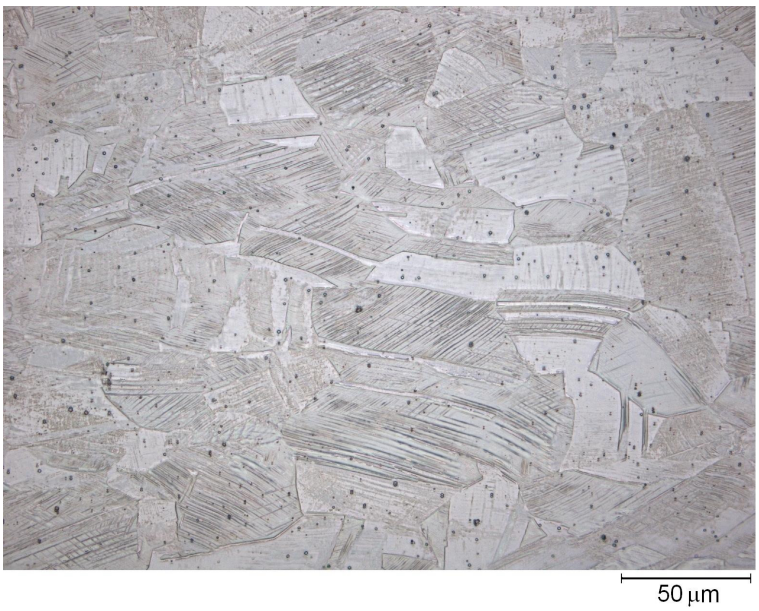

(d)

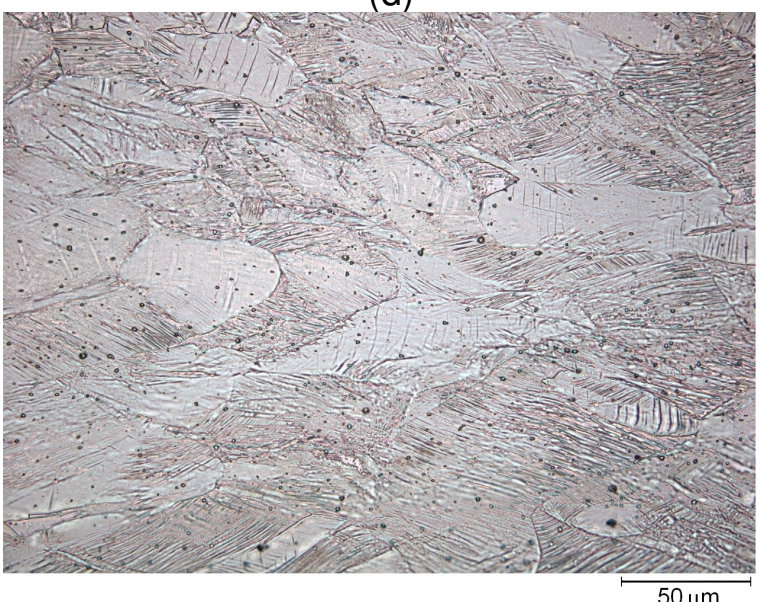

(f)

Figura 54 - Microestruturas representativas do aço AISI 304 laminado em diferentes graus de redução: (a) $5 \%$, (b) $10 \%$, (c) $15 \%$, (d) $20 \%$, (e) 25\%, (f) 30\%. Ataque em ácido oxálico eletrolítico. MO. Ampliação de 500x.

A partir de $10 \%$ de redução obtiveram-se algumas evidências da presença de martensita utilizando $\mathrm{MO}$, sempre dentro dos grãos de austenita e na forma de conjunto de agulhas formando pequenos "blocos"; a martensita observada forma-se 
em poucos locais de forma heterogênea. De fato, as martensitas $\alpha^{\prime}$ e $\varepsilon$ só podem ser visualizadas e identificadas de forma inequívoca por difração de elétrons em área selecionada (SAD: Selected Area Diffraction) no MET; a resolução do $\mathrm{MO}$ é insuficiente. Em geral, foi observado que a quantidade de martensita induzida por deformação aumenta com o aumento da redução. Mesmo com a maior redução adotada neste trabalho, 30\%, a amostra ainda apresenta em sua microestrutura martensita em meio à austenita, sem transformação de fase. Ainda no estágio de 30\% de deformação, os contornos de grão do aço AISI 201 são nítidos quando revelados por meio de ataque de ácido oxálico eletrolítico.

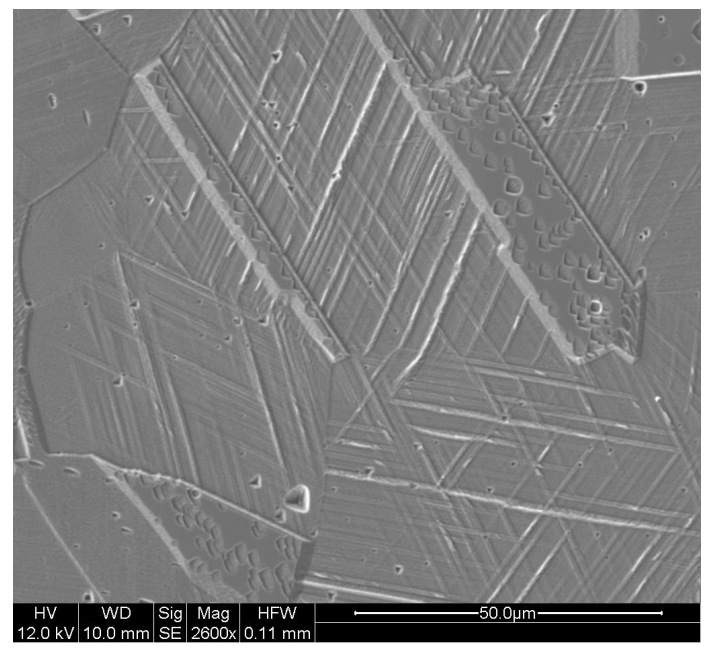

(a)

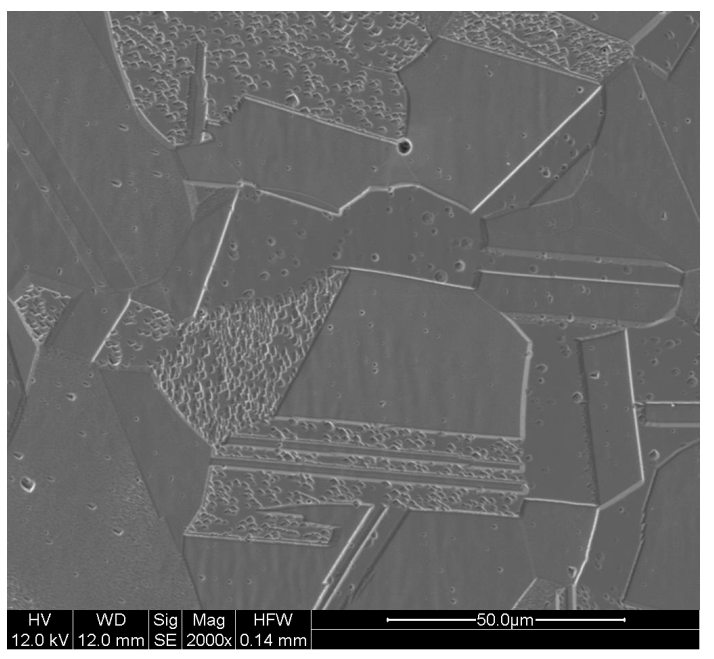

(b)

Figura 55 - Tiras de aço laminado com 5\% de deformação. MEV. (a) AISI 201 e (b) AISI 304. Imagem de elétrons secundários.

Por meio da observação em MEV da amostra laminada com 5\% de deformação do aço AISI 201, foi possível detectar que a nucleação e crescimento da martensita- $\alpha$ ' deram-se a partir das bandas de cisalhamento, como indica a figura 55; ficou evidente que a taxa inicial de transformação de fase foi maior no aço AISI 201 do que no aço AISI 304, fato que é justificável pelo aço AISI 201 possuir menor EDE e maior susceptibilidade na transformação de fase induzida por deformação.

O volume da fração de martensita formada devido à deformação não deve ser avaliado apenas por análise de imagem das microestruturas. A confiabilidade da técnica de metalografia é difícil de mensurar se considerarmos que a anisotropia do polimento e ataque eletrolítico pode conduzir a falsa indicação da quantidade de martensita formada [64]. 
A maioria dos trabalhos publicados na literatura referente ao tema da transformação de fase induzida pela deformação da austenita em martensita para AIA metaestáveis, ou seja, AIAs que contenham baixo teor de níquel e elevado teor de manganês e nitrogênio, concorda com o fato da formação da martensita ser maior com o aumento progressivo da redução durante a laminação [31, 39, 58, 62, 64, 69]. Baseado apenas na análise de $\mathrm{MO}$, não é possível a identificação do tipo de martensita induzida por deformação formada. A análise de DRX foi essencial para a identificação das fases e para diferenciar a formação de martensita $\varepsilon$ nas menores reduções adotadas neste trabalho.

\subsubsection{Dureza}

Para avaliar o efeito da progressão da transformação de fase induzida pela deformação a frio de austenita para martensita, medidas de microdureza também foram realizadas nos aços AISI 201 e AISI 304. A tabela 22 mostra a média de cinco pontos medidos para cada amostra. Para o mesmo grau de deformação, o material AISI 201 apresentou dureza maior do que o aço AISI 304. O aço AISI 201 encrua mais que aço da série 300 devido à adição de manganês e a maior susceptibilidade a transformação de fase induzida por deformação [39]. Correlacionando as

microestruturas com os valores de dureza obtida, é coerente afirmar que a quantidade de martensita induzida por deformação aumenta com o aumento da redução, pois a dureza aumentou com o grau de redução aplicado.

Tabela 22 - Dureza $\left(\mathrm{HV}_{0,1}\right)$ em função do grau de deformação para os aços AISI 201 e AISI 304.

\begin{tabular}{ccc}
\hline Redução (\%) & AISI 201 & AISI 304 \\
\hline $0 \%$ (tira solubilizada) & $206 \pm 2$ & $170 \pm 5$ \\
$5 \%$ & $223 \pm 8$ & $198 \pm 6$ \\
$10 \%$ & $277 \pm 10$ & $225 \pm 6$ \\
$15 \%$ & $345 \pm 22$ & $305 \pm 5$ \\
$20 \%$ & $430 \pm 18$ & $343 \pm 16$ \\
$25 \%$ & $462 \pm 28$ & $389 \pm 13$ \\
$30 \%$ & $492 \pm 10$ & $405 \pm 12$ \\
\hline
\end{tabular}


Os mesmos resultados da tabela 22 foram dispostos na forma de gráfico, conforme indica a figura 56, para melhor visualização e comparação com experiências obtidas na literatura.

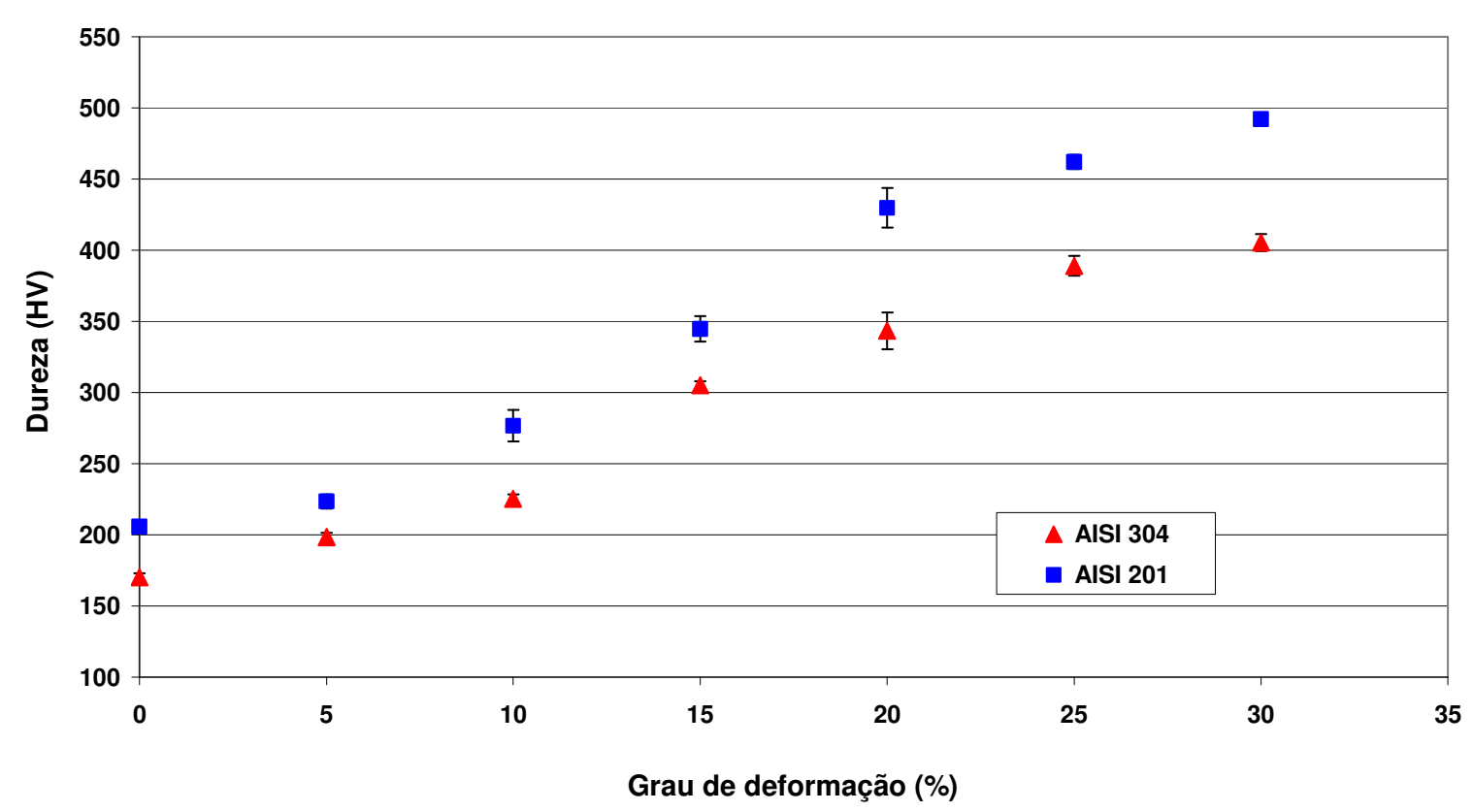

Figura 56 - Variação da dureza em função do grau de deformação durante a laminação.

O único trabalho [39] encontrado na literatura comparando os aços das séries 200 e 300 em relação à transformação de fase induzida por laminação a frio também avaliou a dureza com a evolução do grau de deformação. Tavares e co-autores [39] trabalharam com o aço AISI 201 modificado (por conter cobre em sua composição) e com o aço AISI 304. Assim como o estudo realizado neste trabalho, a curva de dureza dos aços publicados por Tavares e co-autores [39] obteve comportamento similar, ou seja, a dureza aumentou progressivamente com o aumento do grau de deformação. Para ambos os trabalhos, o aço AISI 201 apresentou maior encruamento que o aço AISI 304 laminado. Este fato é justificado pela maior susceptibilidade do aço AISI 201 possuir menor EDE e maior susceptibilidade na transformação de fase induzida por deformação. Hedayati e co-autores [64] e Milad e co-autores [72] avaliaram a dureza do aço AISI 304 em função do grau de deformação. Durezas similares foram obtidas para os mesmos graus de deformação, atingindo cerca de $400 \mathrm{HV}$ para a deformação máxima adotada neste trabalho, de $30 \%$. 


\subsubsection{Medidas magnéticas}

As fitas dos aços AISI 201 e AISI 304 laminadas também foram avaliadas com o auxílio do ferritoscópio para a identificação da porcentagem de fase magnética. A tabela 23 mostra a média de 10 pontos medidos ao longo da superfície das tiras laminadas.

Tabela 23 - Medidas magnéticas em função do grau de deformação para os aços AISI 201 e 304.

\begin{tabular}{ccc}
\hline Redução (\%) & AISI $\mathbf{2 0 1}$ & AISI $\mathbf{3 0 4}$ \\
\hline $0 \%$ (tira solubilizada) & $0,01 \pm 0,0$ & $0,01 \pm 0,0$ \\
$5 \%$ & $1,0 \pm 0,3$ & $0,7 \pm 0,2$ \\
$10 \%$ & $2,0 \pm 0,3$ & $1,1 \pm 0,3$ \\
$15 \%$ & $3,6 \pm 0,3$ & $2,2 \pm 0,3$ \\
$20 \%$ & $8,1 \pm 1,0$ & $5,2 \pm 0,7$ \\
$25 \%$ & $10,5 \pm 0,6$ & $6,7 \pm 1,2$ \\
$30 \%$ & $15,6 \pm 0,5$ & $9,4 \pm 0,5$ \\
\hline
\end{tabular}

Os mesmos resultados da tabela 23 foram dispostos na forma de gráficos para melhor visualização, conforme a figura 57. A porcentagem de fase magnética aumentou com o aumento do grau de deformação. Da mesma maneira que foi observada uma diferença no comportamento dos aços selecionados neste trabalho, sendo que o aço AISI 201 apresentou maior encruamento do que o aço AISI 304 para o mesmo grau de deformação, a porcentagem de fase magnética também é maior para o aço da série 200 quando comparado ao aço AISI 304 para todos os graus de deformação adotados neste trabalho. A ordem de grandeza da porcentagem de martensita- $\alpha$ ' (fase magnética) medido por ferritoscópio obtida para este trabalho está coerente ao apresentado na literatura [72]. Milad e co-autores [72] avaliaram o volume de fração de martensita- $\alpha$ ' em seu trabalho após laminação a frio do aço AISI 304; para $30 \%$ de deformação foi determinado $12 \%$ de fase magnética, muito similar ao encontrado no aço AISI 304 neste trabalho, com valores próximos de $10 \%$. Nenhuma referência foi obtida na literatura para efeito de comparação da porcentagem de fase magnética medida por ferritoscópio para o aço AISI 201. 


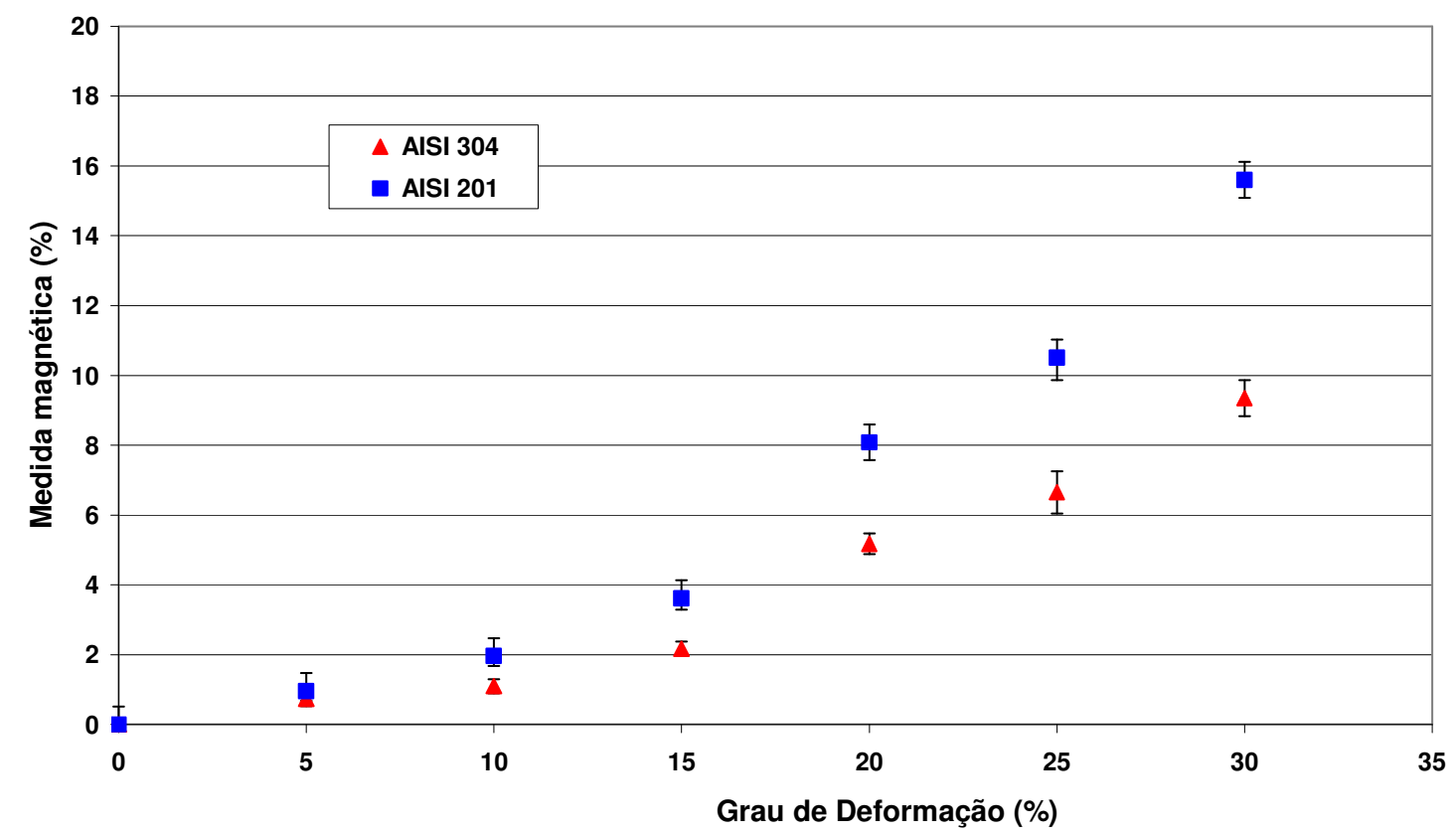

Figura 57 - Variação da porcentagem de fase magnética em função do grau de deformação durante laminação.

\subsubsection{Difração de raios $\mathrm{X}$}

Os difratogramas dos aços AISI 201 e AISI 304 para cada condição de deformação, de 5 a $30 \%$ estão nas figuras 58 e 59, respectivamente. As análises de DRX foram realizadas em temperatura ambiente e com radiação de $\mathrm{Cu} K \alpha$. A difração individual dos planos da austenita CFC, da martensita- $\varepsilon$ HC e a martensita$\alpha$ ' CCC foram claramente identificadas nos aços AISI 201 e AISI 304. Apesar de muitos trabalhos na literatura afirmarem que a identificação dos picos da martensita$\varepsilon$ é muito difícil [64], os dois aços estudados neste trabalho apresentaram formação da martensita- $\varepsilon$ devido à laminação a frio para as menores reduções, até $15 \%$. A

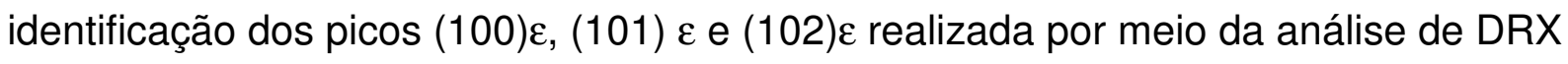
foi evidente e indicam a formação da martensita- $\varepsilon$. Não houve interferência de picos e as suas intensidades são suficientes para a efetivação da medição. De fato, os mesmos picos identificados nas tiras do aço laminado AISI 304 também foram identificados para o aço laminado AISI 201, diferindo pela intensidade em cada redução estudada. Os picos (110) $\alpha^{\prime},(222) \alpha^{\prime},(200) \alpha^{\prime}$ e (211) $\alpha^{\prime}$ também foram identificados para a martensita- $\alpha$. Os picos de maior intensidade foram os 
relacionados à identificação da fase da austenita, como $(111) \gamma,(200) \gamma,(220) \gamma,(311) \gamma$. Além da análise qualitativa de identificação das fases, a análise de DRX também realiza a análise quantitativa. Conforme já discutido anteriormente, a análise realizada com ferritoscópio não identifica a porcentagem de martensita- $\varepsilon$, por ela não ser magnética. Desta forma, a análise de DRX é essencial para a identificação e quantificação das três fases envolvidas na transformação de fase induzida por deformação: austenita, martensita- $\alpha$ ' e martensita- $\varepsilon$.

O aço da série 200 apresentou formação de martensita- $\alpha$ ' logo na menor redução aplicada, de $5 \%$. O aumento da redução apenas intensificou a formação da mesma fase. Já a fase de martensita- $\varepsilon$ foi identificada somente para as reduções de 10 e $15 \%$, ao contrário do aço AISI 304. Neste aço houve formação de martensita$\varepsilon$ para as duas menores reduções aplicadas, de 5 e $10 \%$. 


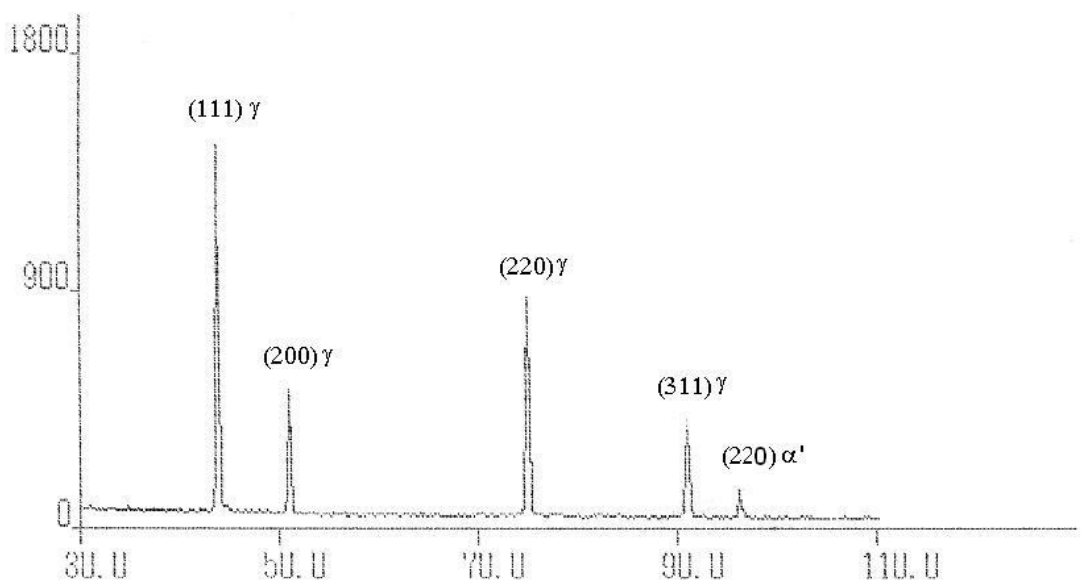

(a)

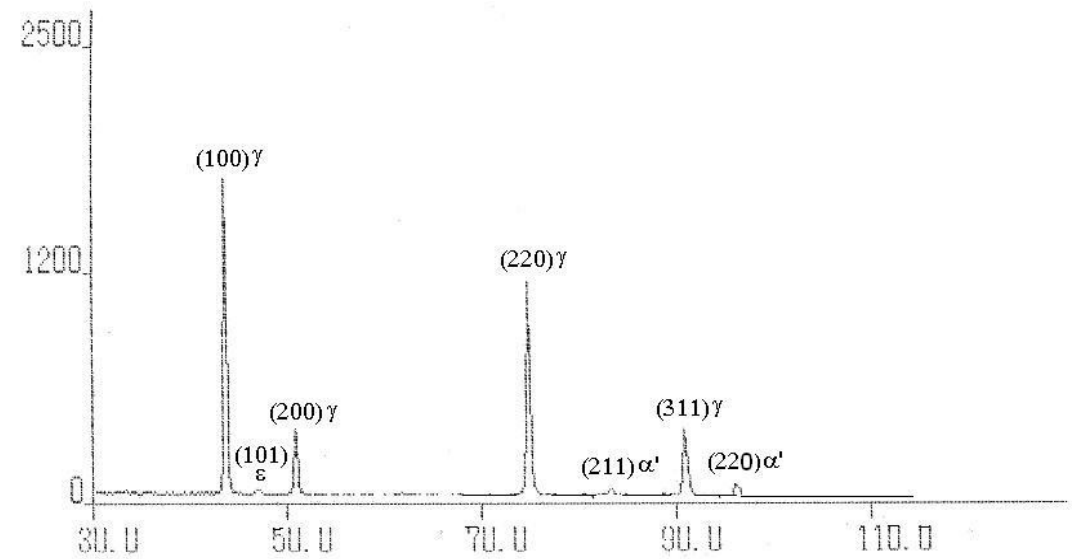

(b)

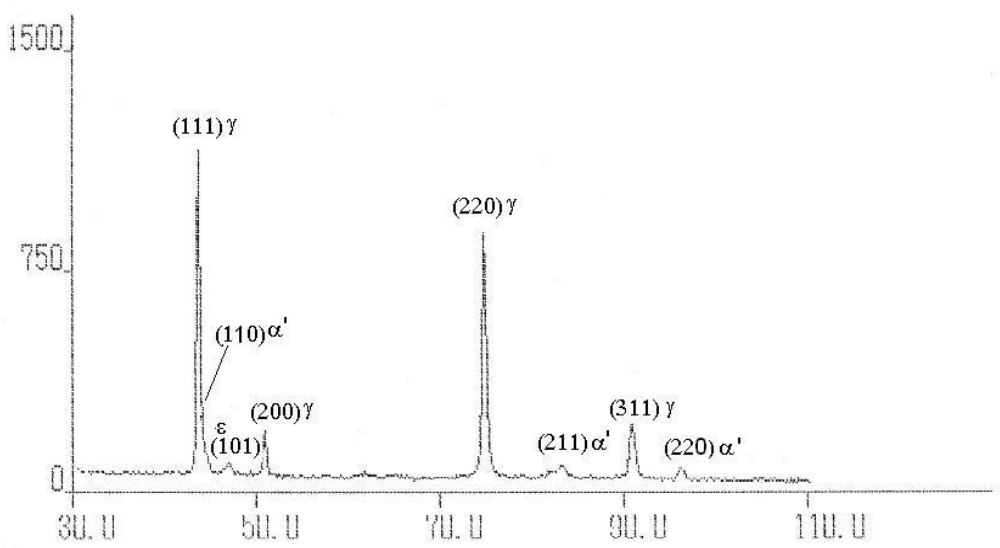

(c) 


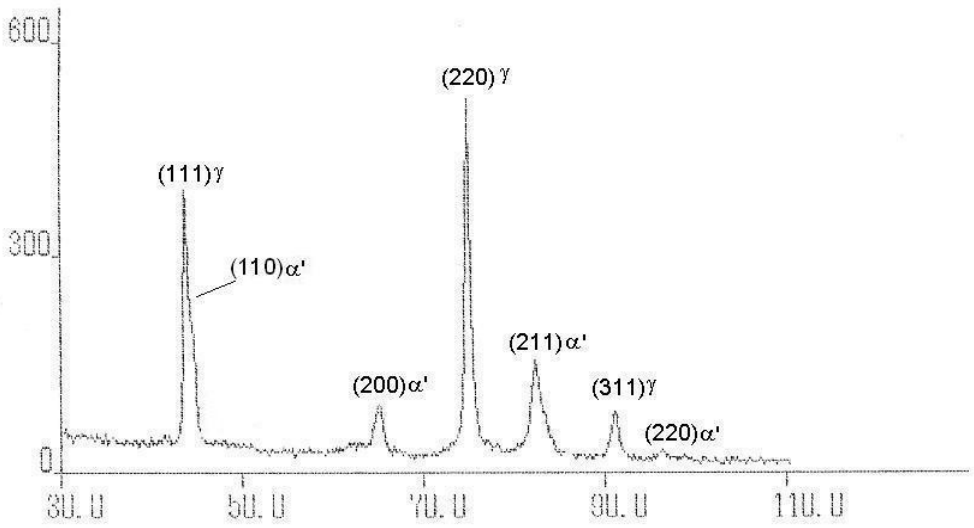

(d)

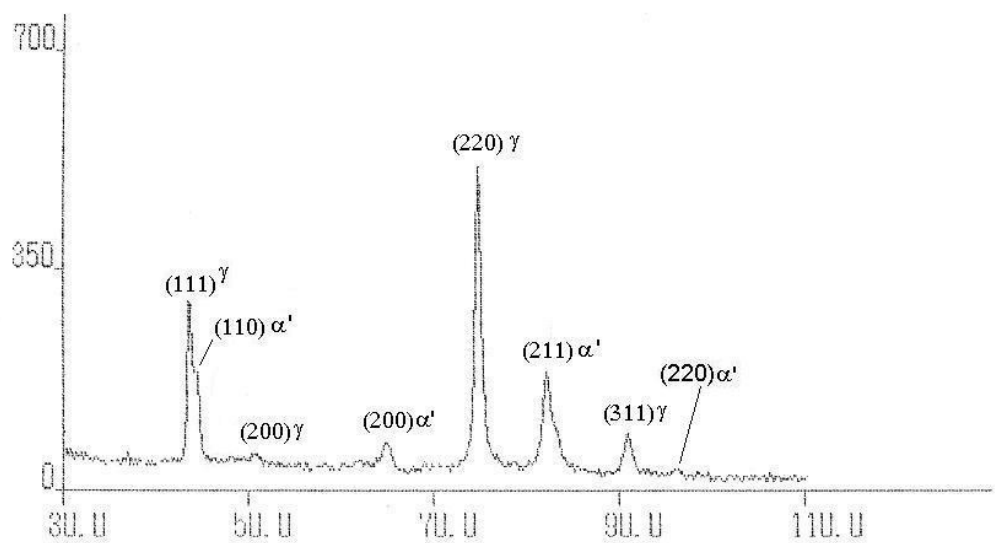

(e)

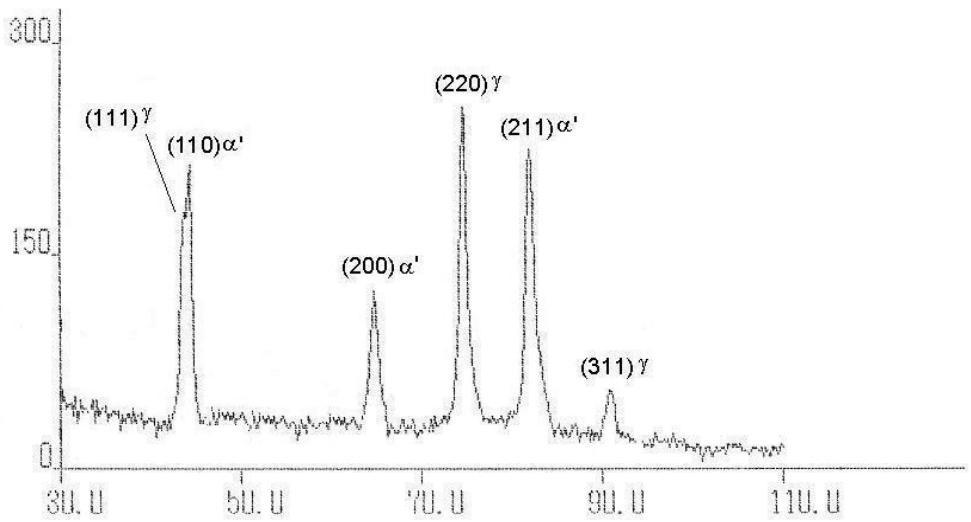

(f)

Figura 58 - Difratogramas representativos dos aços AISI 201 laminado em diferentes graus de redução: (a) 5\%, (b) $10 \%$, (c) $15 \%$, (d) $20 \%$, (e) $25 \%$, (f) $30 \%$. Radiação CuKo. 


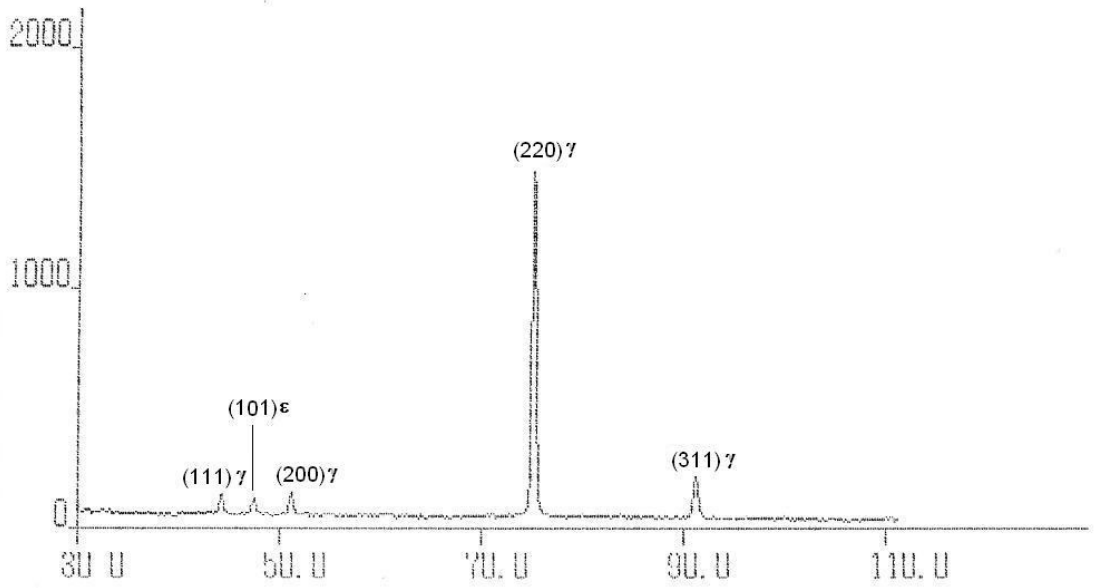

(a)

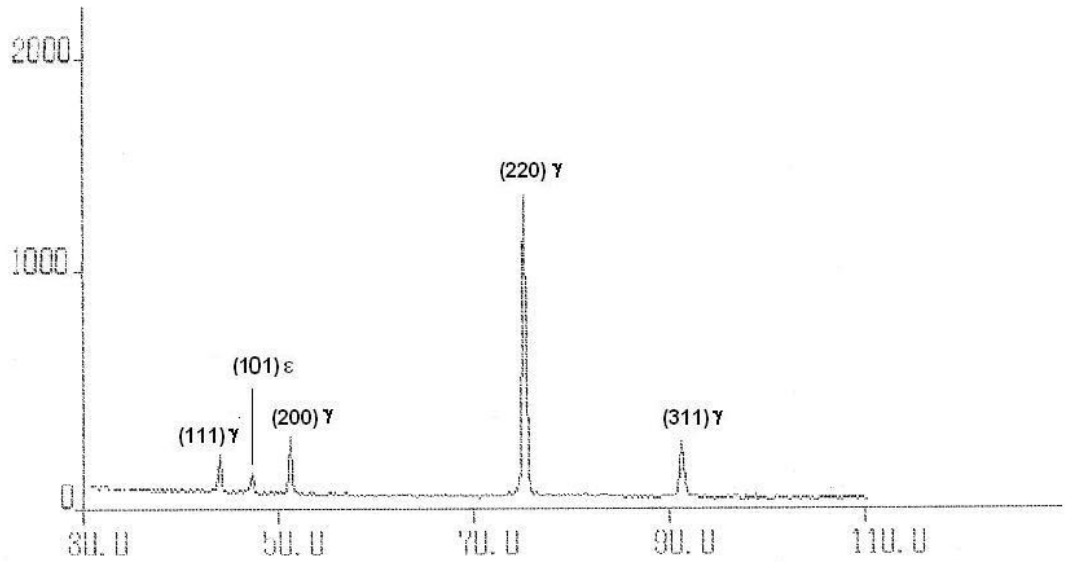

(b)

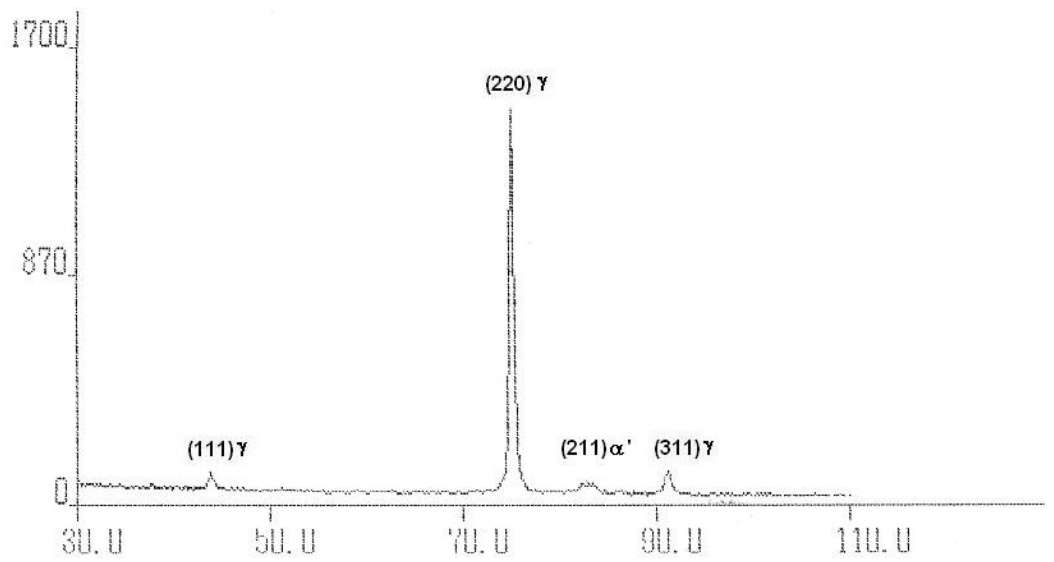

(c) 


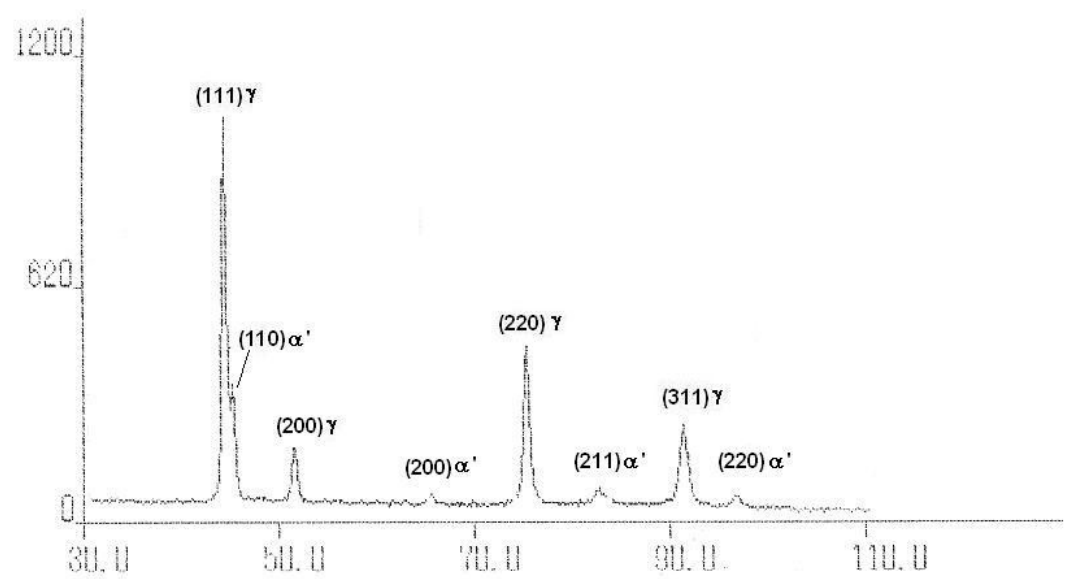

(d)

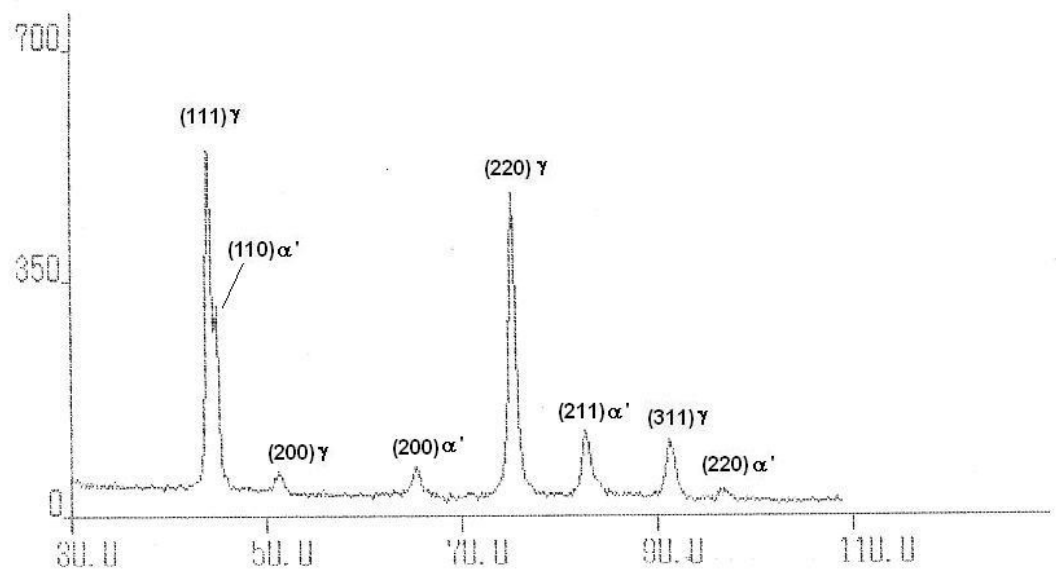

(e)

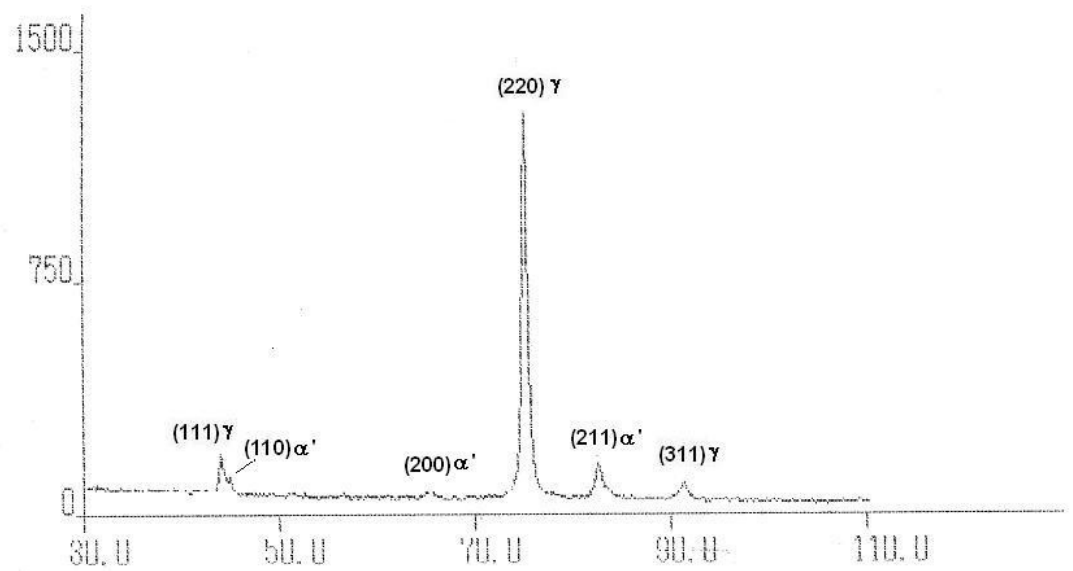

(f)

Figura 59 - Difratogramas representativos dos aços AISI 304 laminado em diferentes graus de redução: (a) 5\%, (b) 10\%, (c) 15\%, (d) 20\%, (e) 25\%, (f) 30\%. Radiação CuK $\alpha$.

A seqüência de transformação martensítica induzida por deformação no aço AISI 304, evidenciada pela análise de DRX, está de acordo com a proposta de 
Mangonon e Thomas [69] e Seetharaman e Krishnan [75], ou seja, para AIAs metaestáveis de baixa EDE, como o aço AISI 304, a transformação martensítica induzida por deformação é formada pela seqüência $\gamma \rightarrow \varepsilon \rightarrow \alpha$. Apesar do aço AISI 201 apresentar menor EDE que o aço AISI 304, e, portanto também ter a tendência de seguir a seqüência de transformação indicada, na prática este comportamento não foi observado.

A figura 60 a seguir, mostra em forma gráfica os valores em porcentagem das fases identificadas por meio da análise de DRX em função do grau de deformação por laminação a frio. Foi possível quantificar a porcentagem das martensita- $\alpha$, martensita- $\varepsilon$ e austenita para cada grau de deformação aplicado integrando a curva identificada no difratograma. Para ambos os aços foram identificados que a quantidade de martensita- $\alpha$ ' aumenta com o aumento do grau de deformação e conseqüentemente a quantidade de austenita diminui. De maneira similar, o trabalho de De e co-autores [85] também evidenciou o mesmo comportamento para o aço AISI 304.

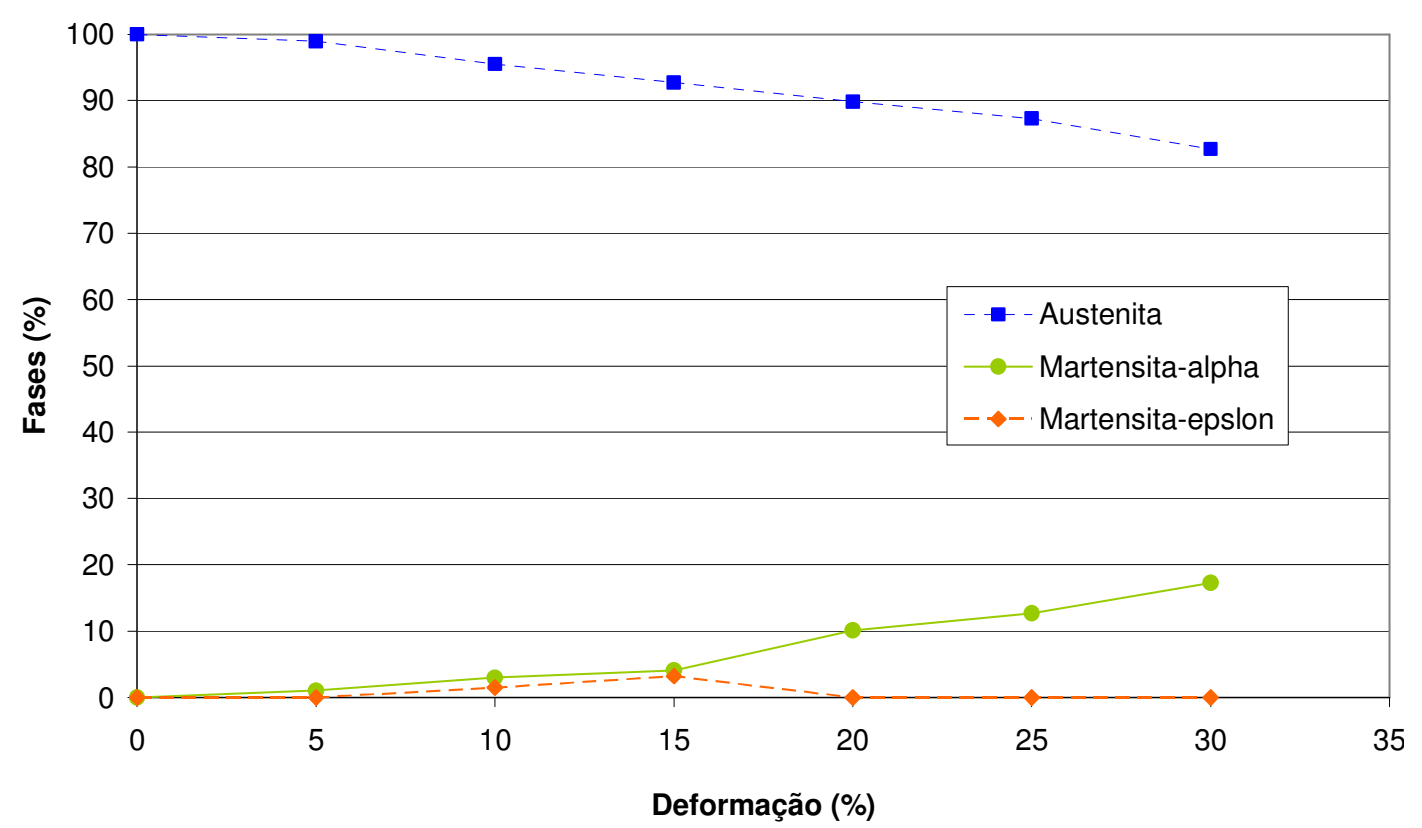

(a) 


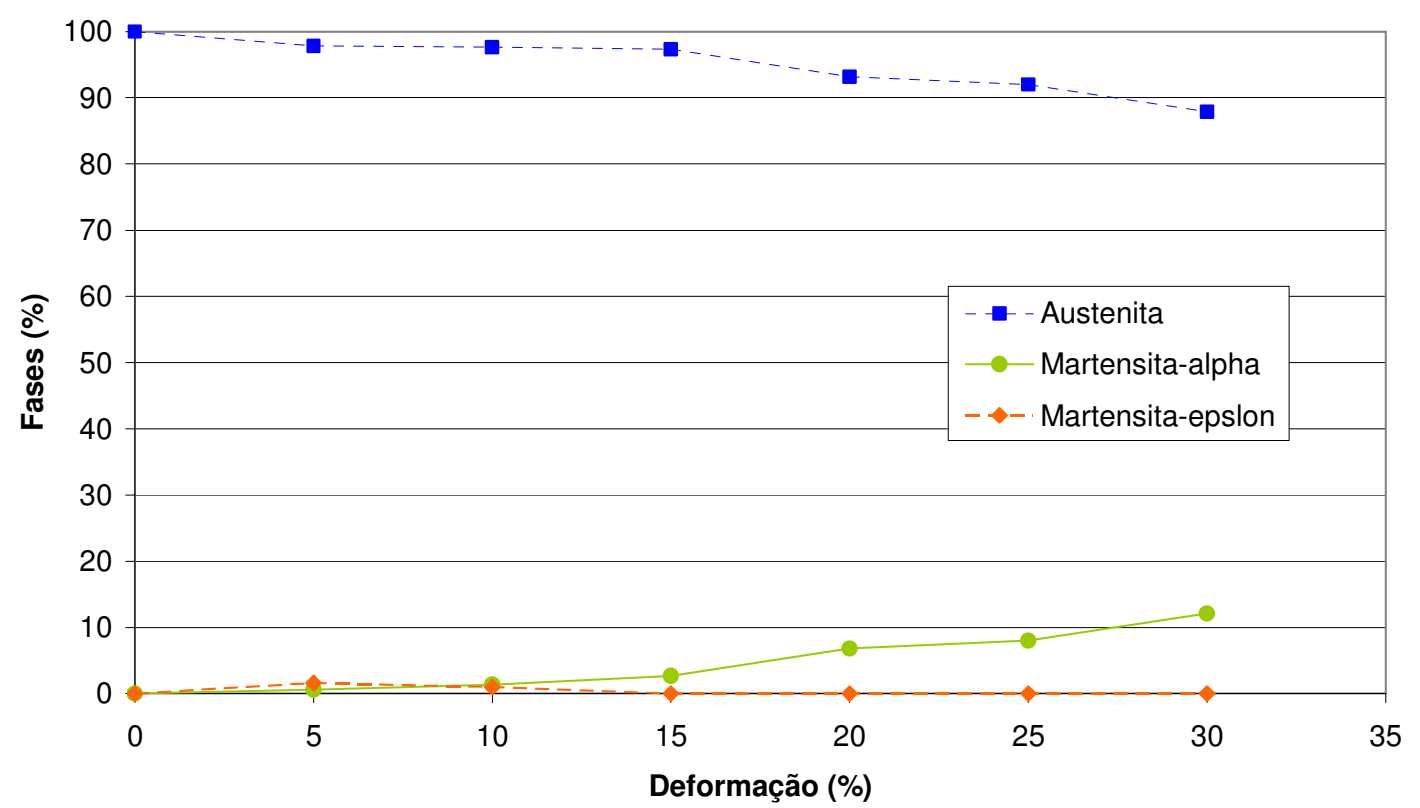

(b)

Figura 60 - Fração volumétrica de fases nos aços laminados (a) AISI 201 e (b) AISI 304.

Por meio de difração de raios $X(D R X)$ é possível identificar de forma inequívoca a presença de martensita induzida por deformação. Apesar do limite de detecção da análise de DRX ser baixo, em torno de 1-3\% em volume, ainda sim foi possível detectar a porcentagem das fases de martensitas $\varepsilon$ e $\alpha$ '. A martensita- $\varepsilon$ também aumentou com o grau de deformação, atingindo o máximo em $15 \%$ de redução para o aço AISI 201 e para 10 \% de redução para o aço AISI 304. Devido à ausência de trabalhos na literatura que discutam a transformação de fase induzida por deformação em aços da série 200, foi complicado referenciar em maiores detalhes a seqüência de transformação obtida por laminação neste trabalho. No entanto, é evidente que o aço AISI 201 apresentou comportamento distinto ao aço AISI 304, pois desde as menores reduções aplicadas, a quantidade de martensita- $\alpha$ ' foi maior que a quantidade de martensita- $\varepsilon$, contradizendo a seqüência proposta na literatura $[69,75]$.

Neste trabalho foram utilizadas duas técnicas de análise quantitativa para avaliar a fração volumétrica (em porcentagem) da fase martensita- $\alpha$ ' magnética, 0 ferritoscópio e a DRX. Comparativamente, ambas as metodologias apresentaram resultados similares e podem ser recomendadas para o uso no estudo da transformação de fase induzida por deformação. Apenas como ressalva, a análise de DRX mostra-se mais completa, por poder identificar e quantificar todas as fases 
presentes no material, independente de suas propriedades magnéticas.

\subsection{Material tracionado}

Inicialmente, as tiras dos dois aços foram tracionadas até a ruptura para avaliação das propriedades mecânicas. A figura 61 ilustra as curvas de tensão em função da deformação para as tiras solubilizadas AISI 201 e AISI 304 a uma velocidade de rampa de $10 \mathrm{~mm} / \mathrm{min}$.

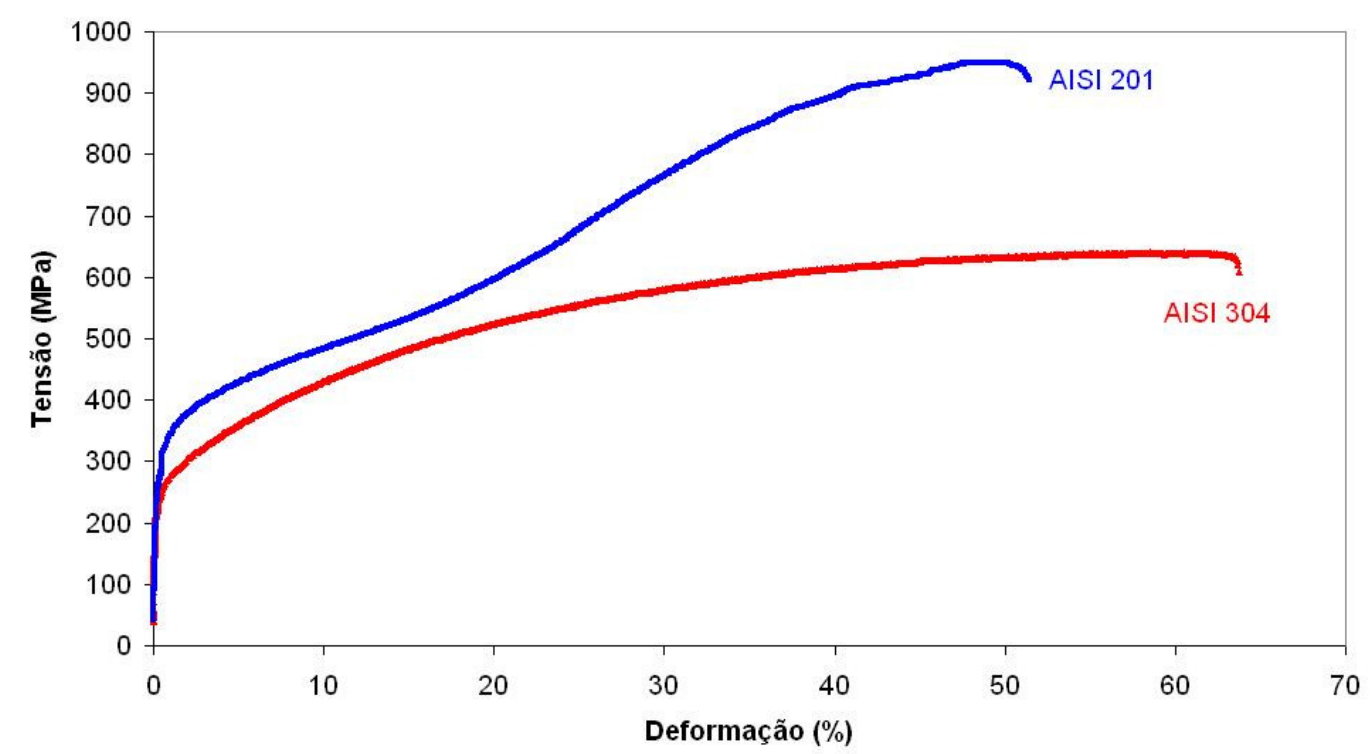

Figura 61 - Curva tensão versus deformação (de engenharia) dos aços solubilizados AISI 201 e AISI 304.

As tabelas 24 e 25 indicam as médias dos valores de limite de resistência (LR), limite de escoamento (LE), alongamento e módulo de elasticidade (E) obtidos por meio de ensaio de tração para os aços AISI 201 e AISI 304, respectivamente. A média e o desvio padrão dos resultados foram obtidos após teste de cinco corpos de prova para cada material. Considerando que ambos os aços foram testados na condição solubilizada, pode-se verificar que o limite de resistência do aço AISI 201 é praticamente 50\% superior que o aço AISI 304 e apresenta menor alongamento. Este fato é justificável devido ao aço AISI 201 apresentar teor de nitrogênio duas vezes maior do que no aço AISI 304. Esta maior quantidade de nitrogênio na composição do aço AISI 201 provoca o aumento da resistência devido ao endurecimento por solução sólida dos solutos intersticiais [46, 48]. A relação de limite de resistência e limite de escoamento é um indício referente ao comportamento ao encruamento do material. O aço AISI 201 apresentou uma média 
da relação LR/LE de 3,5, superior ao aço AISI 304 o que significa que ele encrua mais que o aço AISI 304.

Tabela 24 - Propriedades mecânicas do aço AISI 201.

\begin{tabular}{cccccc}
\hline Corpo de prova & LR (MPa) & LE (MPa) & Alongamento (\%) & E (GPa) & LR/LE \\
\hline 1 & 980 & 284 & 50 & 206 & 3,4 \\
2 & 993 & 275 & 52 & 207 & 3,6 \\
3 & 982 & 280 & 49 & 208 & 3,5 \\
4 & 979 & 272 & 45 & 206 & 3,6 \\
5 & 988 & 280 & 48 & 207 & 3,5 \\
\hline Média & $\mathbf{9 8 4} \pm \mathbf{6}$ & $\mathbf{2 7 8} \pm \mathbf{5}$ & $\mathbf{4 9 \pm \mathbf { 3 }}$ & $\mathbf{2 0 7 \pm \mathbf { 1 }}$ & $\mathbf{3 , 5}$ \\
\hline
\end{tabular}

Tabela 25 - Propriedades mecânicas do aço AISI 304.

\begin{tabular}{cccccc}
\hline Corpo de prova & LR (MPa) & LE (MPa) & Alongamento (\%) & E (GPa) & LR/LE \\
\hline 1 & 648 & 213 & 68 & 199 & 3,0 \\
2 & 632 & 212 & 64 & 194 & 2,9 \\
3 & 632 & 217 & 65 & 202 & 2,9 \\
4 & 628 & 207 & 60 & 200 & 3,0 \\
5 & 636 & 218 & 62 & 202 & 2,9 \\
\hline Média & $\mathbf{6 3 5 \pm \mathbf { 8 }}$ & $\mathbf{2 1 3} \pm \mathbf{4}$ & $\mathbf{6 4} \pm \mathbf{3}$ & $\mathbf{1 9 9} \pm \mathbf{3}$ & $\mathbf{2 , 9}$ \\
\hline
\end{tabular}

Além dos ensaios de tração até a ruptura, outros ensaios também foram realizados, porém interrompidos em determinados graus de deformação. Os mesmos graus de deformação adotados para as laminações a frio também foram estabelecidas para avaliar o modo de deformação, comparativamente aos aços laminados.

\subsubsection{Caracterização metalográfica}

Ensaios de tração interrompidos das tiras dos aços AISI 201 e AISI 304 foram realizados, na mesma taxa de deformação definida para a laminação, ou seja, 10 $\mathrm{mm} / \mathrm{min}$. As tiras AISI 201 e AISI 304 foram caracterizadas por meio de MO, conforme figura 62 e 63, respectivamente.

As figuras 62 e 63 mostram a progressão das microestruturas dos aços AISI 201 e AISI 304, respectivamente. As fitas dos aços selecionados foram tracionadas e 
interrompidas em 5\% (a) até a redução máxima adotada neste trabalho de 30\% (f). Após preparação metalográfica é possível visualizar a austenita como a fase clara e a martensita como a fase escura na forma de agulhas finas. Na tira do aço AISI 201 tracionada até atingir $5 \%$ de deformação (figura 62 (a)), há indícios da presença de martensita por meio da análise de $\mathrm{MO}$, ao contrário da amostra laminada na mesma redução adotada. Em todas as amostras tracionadas e interrompidas até 30\% ficou evidente a progressão da formação de martensita. Apenas a análise de $\mathrm{MO}$ não é suficiente para afirmar se há presença das martensitas $\alpha$ 'e $\varepsilon$. Como já foi discutido anteriormente, a melhor maneira de identificar essas fases é o uso de MET. Comparativamente, houve muito mais formação de martensita nas fitas tracionadas do aço AISI 201 do que nas fitas do aço AISI 304. Da mesma maneira que foi observada para as tiras laminadas, a análise das microestruturas das tiras tracionadas mostrou que a taxa inicial de transformação de fase foi maior no aço AISI 201 do que no aço AISI 304, fato que é justificável pelo aço AISI 201 possuir menor EDE e maior susceptibilidade na transformação de fase induzida por deformação. 


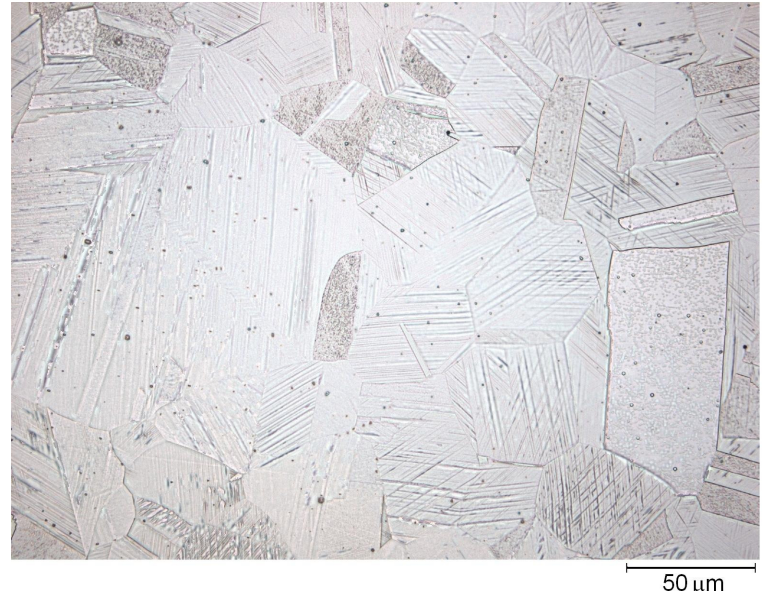

(a)

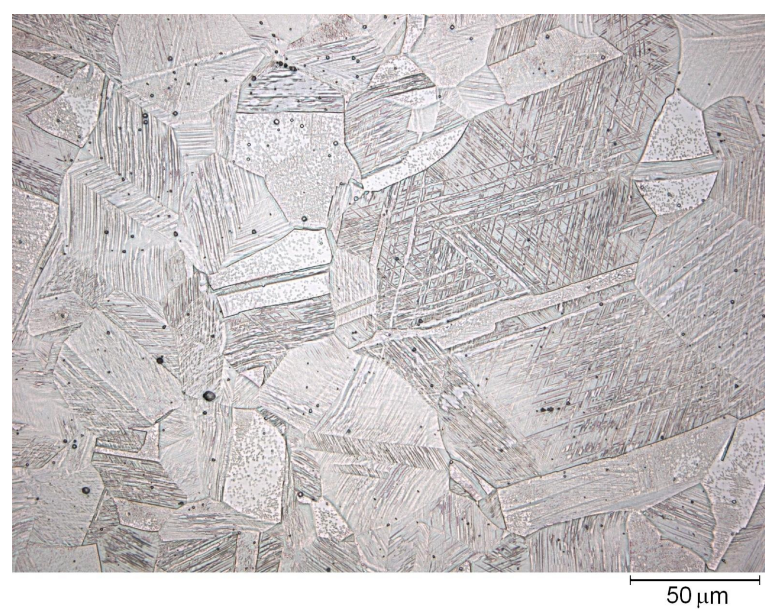

(c)

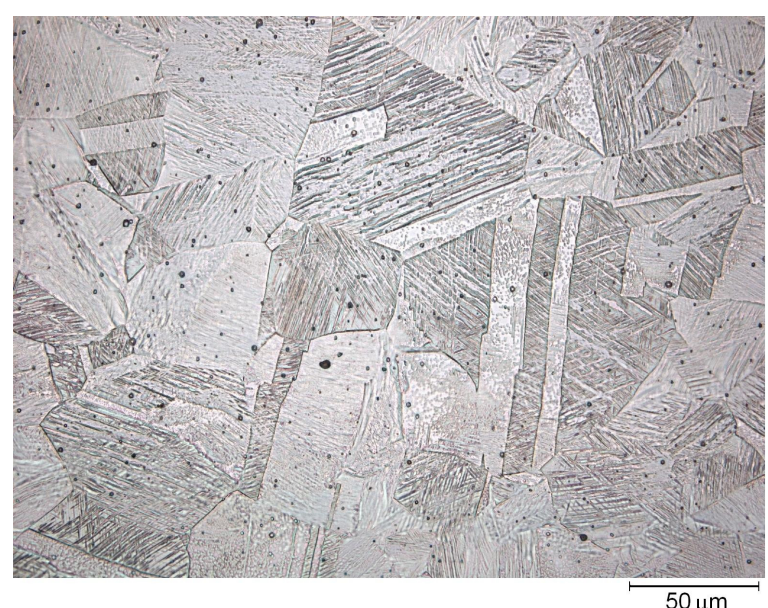

(e)

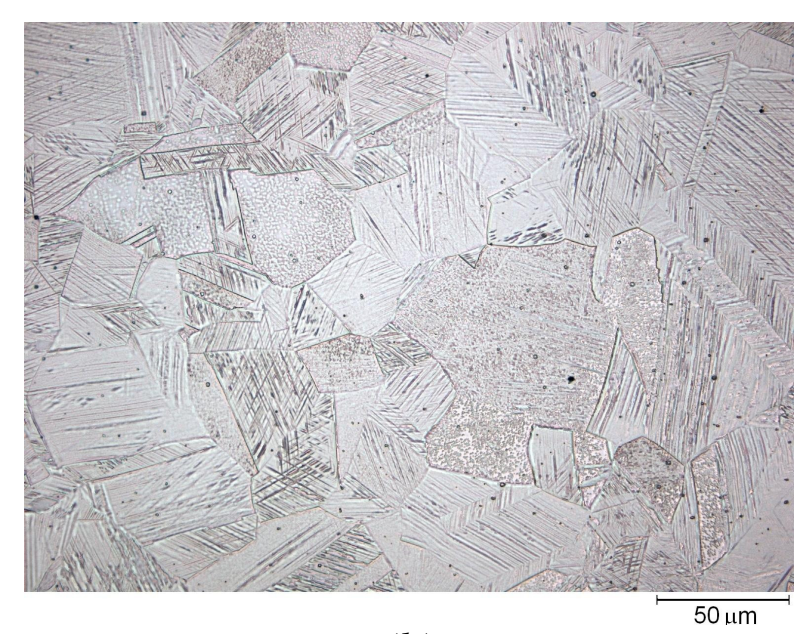

(b)

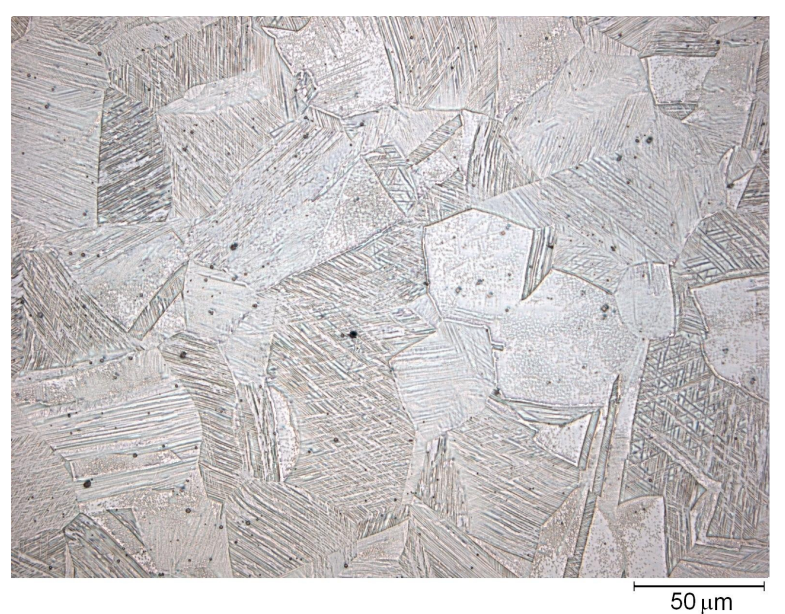

(d)

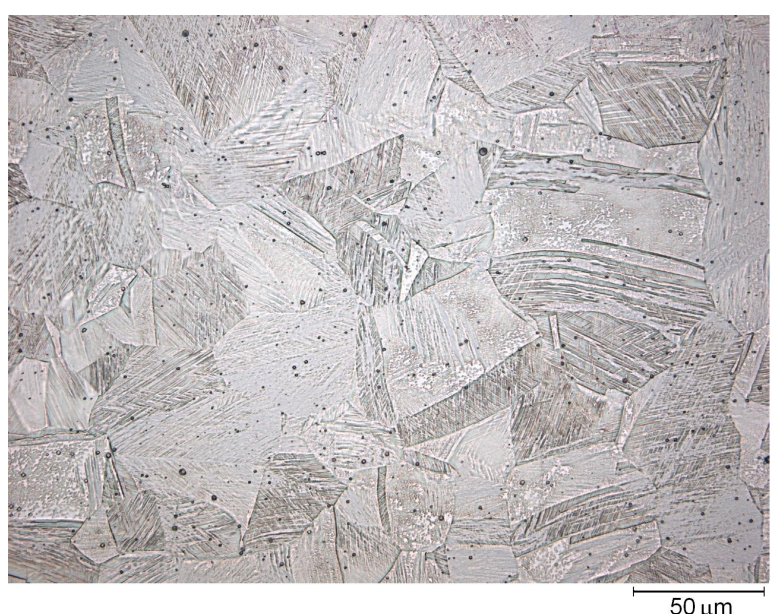

(f)

Figura 62 - Microestruturas representativas do aço AISI 201 tracionado a uma velocidade de 10 $\mathrm{mm} / \mathrm{min}$ em diferentes graus de redução: (a) $5 \%$, (b) $10 \%$, (c) $15 \%$, (d) $20 \%$, (e) $25 \%$, (f) $30 \%$. Ataque em ácido oxálico eletrolítico. MO. Ampliação de 500x. 


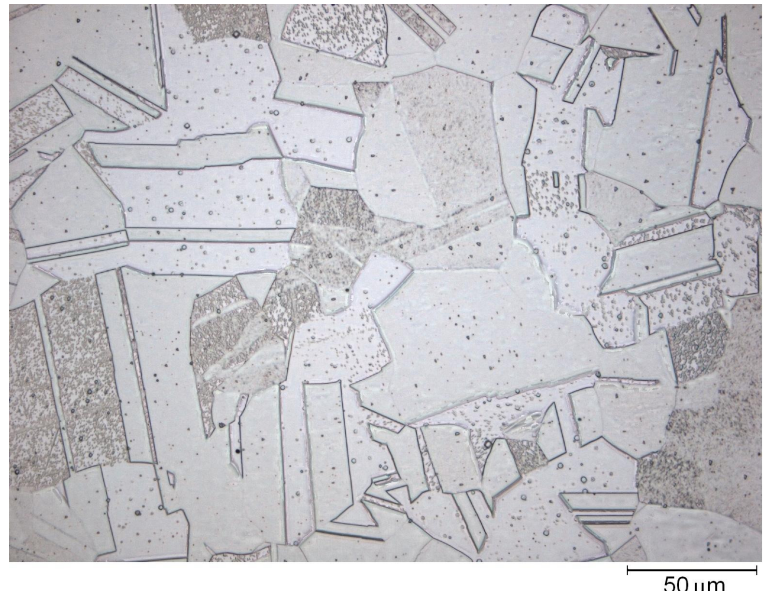

(a)

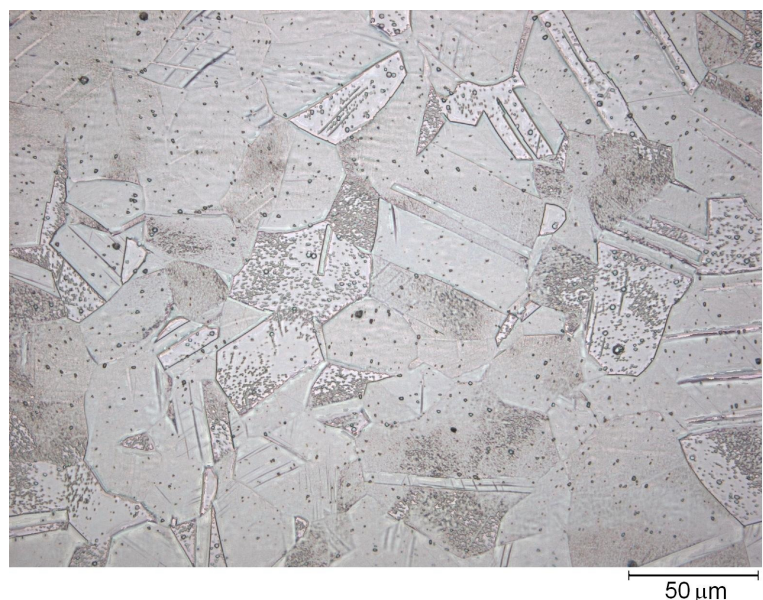

(c)

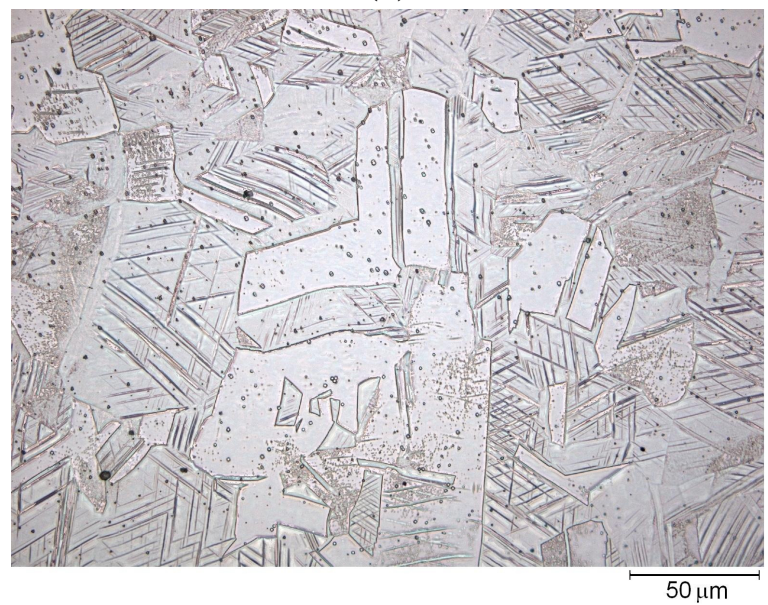

(e)

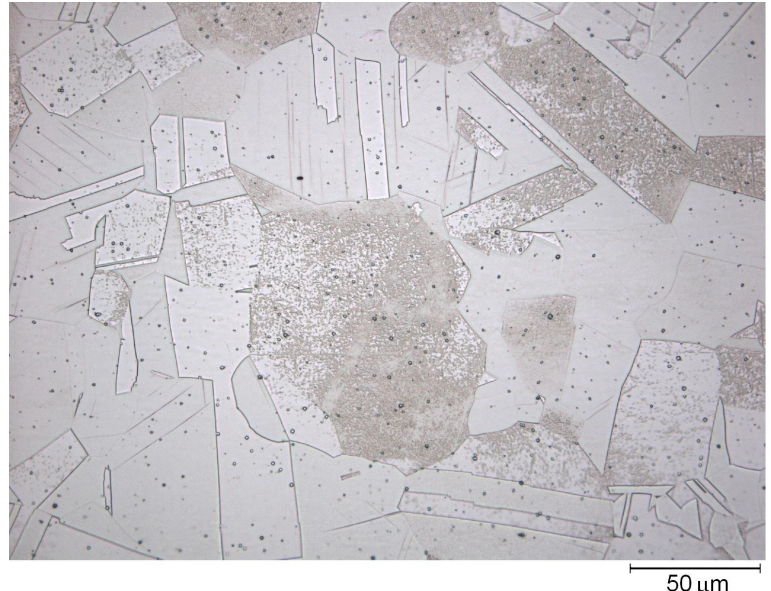

(b)

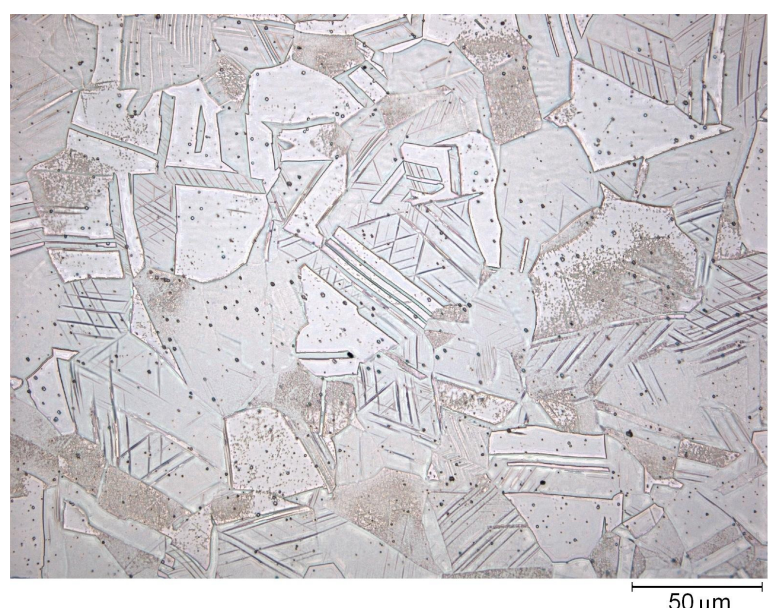

(d)

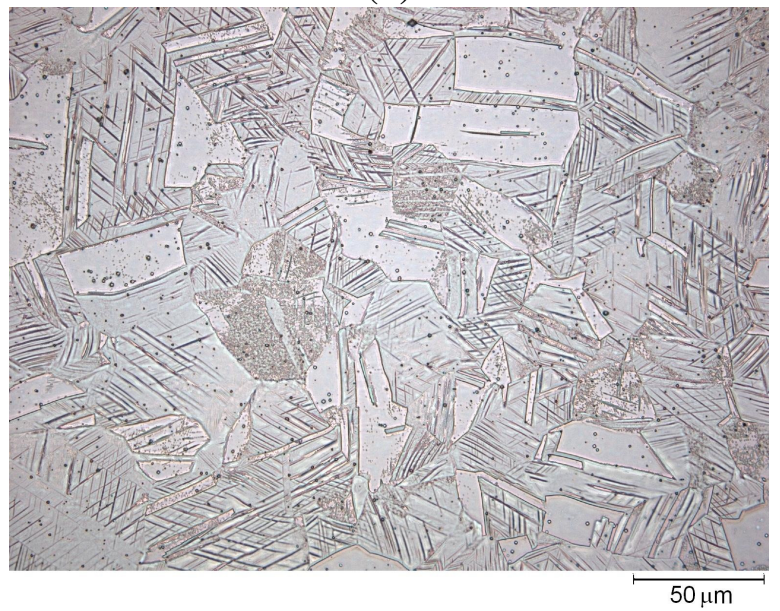

(f)

Figura 63 - Microestruturas representativas do aço AISI 304 tracionado a uma velocidade de 10 $\mathrm{mm} / \mathrm{min}$ em diferentes graus de redução: (a) $5 \%$, (b) $10 \%$, (c) $15 \%$, (d) $20 \%$, (e) $25 \%$, (f) $30 \%$. Ataque em ácido oxálico eletrolítico. MO. Ampliação de 500x. 


\subsubsection{Dureza}

Medidas de microdureza também foram realizadas nos aços AISI 201 e AISI 304 após interrupção do ensaio de tração para avaliar o efeito da progressão da transformação de fase induzida pela deformação a frio de austenita para martensita. A tabela 26 mostra a média de cinco pontos medidos ao longo das secções metalográficas para cada amostra. Para o mesmo grau de deformação, o material AISI 201 apresentou dureza maior do que o aço AISI 304. É válido afirmar que a quantidade de martensita induzida por deformação aumenta com o aumento da redução aplicada, pois a dureza aumentou com o grau de redução aplicado.

Tabela 26 - Dureza $\left(\mathrm{HV}_{0,1}\right)$ em função do grau de deformação do ensaio de tração para os aços AISI 201 e AISI 304.

\begin{tabular}{ccc}
\hline Redução (\%) & AISI 201 & AISI 304 \\
\hline $0 \%$ (tira solubilizada) & $206 \pm 2$ & $170 \pm 5$ \\
$5 \%$ & $274 \pm 6$ & $191 \pm 7$ \\
$10 \%$ & $345 \pm 4$ & $215 \pm 3$ \\
$15 \%$ & $358 \pm 7$ & $250 \pm 12$ \\
$20 \%$ & $371 \pm 13$ & $264 \pm 6$ \\
$25 \%$ & $431 \pm 10$ & $273 \pm 6$ \\
$30 \%$ & $461 \pm 14$ & $278 \pm 11$ \\
\hline
\end{tabular}

Os mesmos resultados da tabela 25 foram dispostos na forma de gráfico, conforme indica a figura 64, para melhor visualização e comparação com experiências obtidas na literatura. 


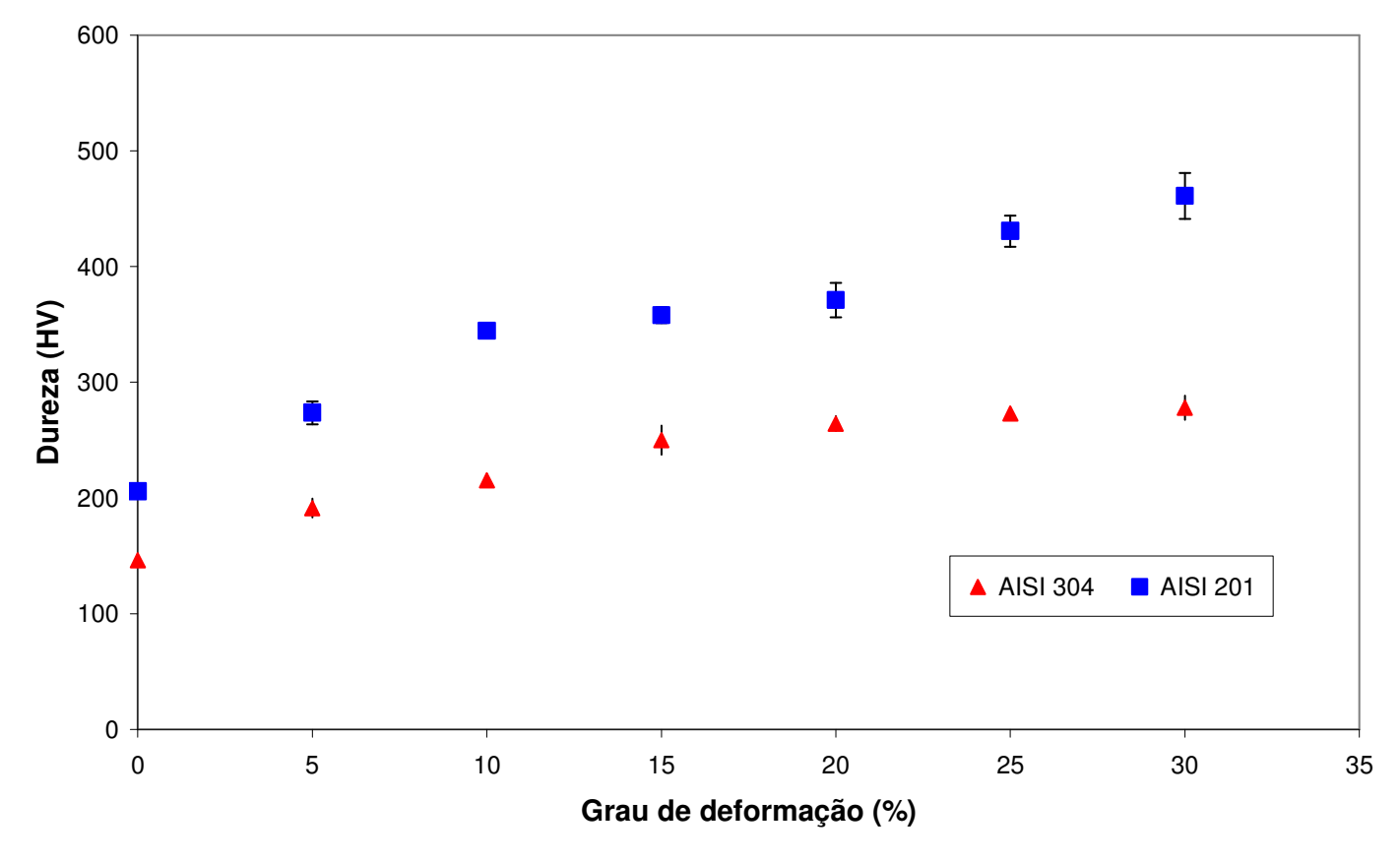

Figura 64 - Dureza das tiras tracionadas.

\subsubsection{Medidas magnéticas}

As fitas dos aços AISI 201 e AISI 304 após ensaio de tração interrompido também foram avaliadas com o auxílio do ferritoscópio para a identificação da porcentagem de fase magnética presente. A tabela 27 mostra a média de 10 pontos medidos ao longo da superfície das tiras laminadas.

Tabela 27 - Medidas magnéticas em função do grau de deformação do ensaio de tração para os aços AISI 201 e AISI 304.

\begin{tabular}{ccc}
\hline Redução (\%) & AISI 201 & AISI 304 \\
\hline $0 \%$ (tira solubilizada) & $0,01 \pm 0,0$ & $0,01 \pm 0,0$ \\
$5 \%$ & $2,7 \pm 0,3$ & $0,5 \pm 0,1$ \\
$10 \%$ & $3,5 \pm 0,6$ & $1,0 \pm 0,3$ \\
$15 \%$ & $6,3 \pm 1,0$ & $2,3 \pm 0,4$ \\
$20 \%$ & $9,2 \pm 1,1$ & $3,5 \pm 0,2$ \\
$25 \%$ & $13,1 \pm 0,9$ & $5,7 \pm 0,3$ \\
$30 \%$ & $16,0 \pm 1,3$ & $7,9 \pm 0,2$ \\
\hline
\end{tabular}

A porcentagem de fase magnética aumentou com o aumento do grau de deformação. Da mesma forma que houve maior encruamento (aumento de dureza) 
do aço AISI 201 em comparação ao aço AISI 304 para o mesmo grau de deformação, a porcentagem de fase magnética também é maior.

\subsubsection{Difração de raios $X$}

Para as tiras dos aços AISI 201 e AISI 304, a análise de DRX foi realizada em temperatura ambiente e com radiação de $\mathrm{Cu} \mathrm{K} \alpha$ para quantificar as fases presentes. Ao contrário das tiras laminadas, não foi identificada a fase martensita- $\varepsilon$ em nenhuma das deformações em que as tiras foram submetidas em ensaio de tração. No entanto, a fase de martensita- $\alpha$ ' foi identificada e quantificada. A figura 65 a seguir, mostra a quantidade (em porcentagem) das fases de austenita e martensita$\alpha^{\prime}$ em função do grau de deformação após ensaio de tração para os aços AISI 201 (figura 65(a)) e AISI 304 (figura 65(b)). Os dois aços apresentaram formação de martensita- $\alpha$ ' logo na menor redução aplicada, de $5 \%$. O aumento da redução apenas intensificou a formação da mesma fase. A quantidade de martensita- $\alpha$ ' formada no aço AISI 201 e praticamente o dobro da quantidade formada no aço AISI 304. Também houve boa correlação de resultados obtidos por meio de análise de DRX e ferritoscópio.

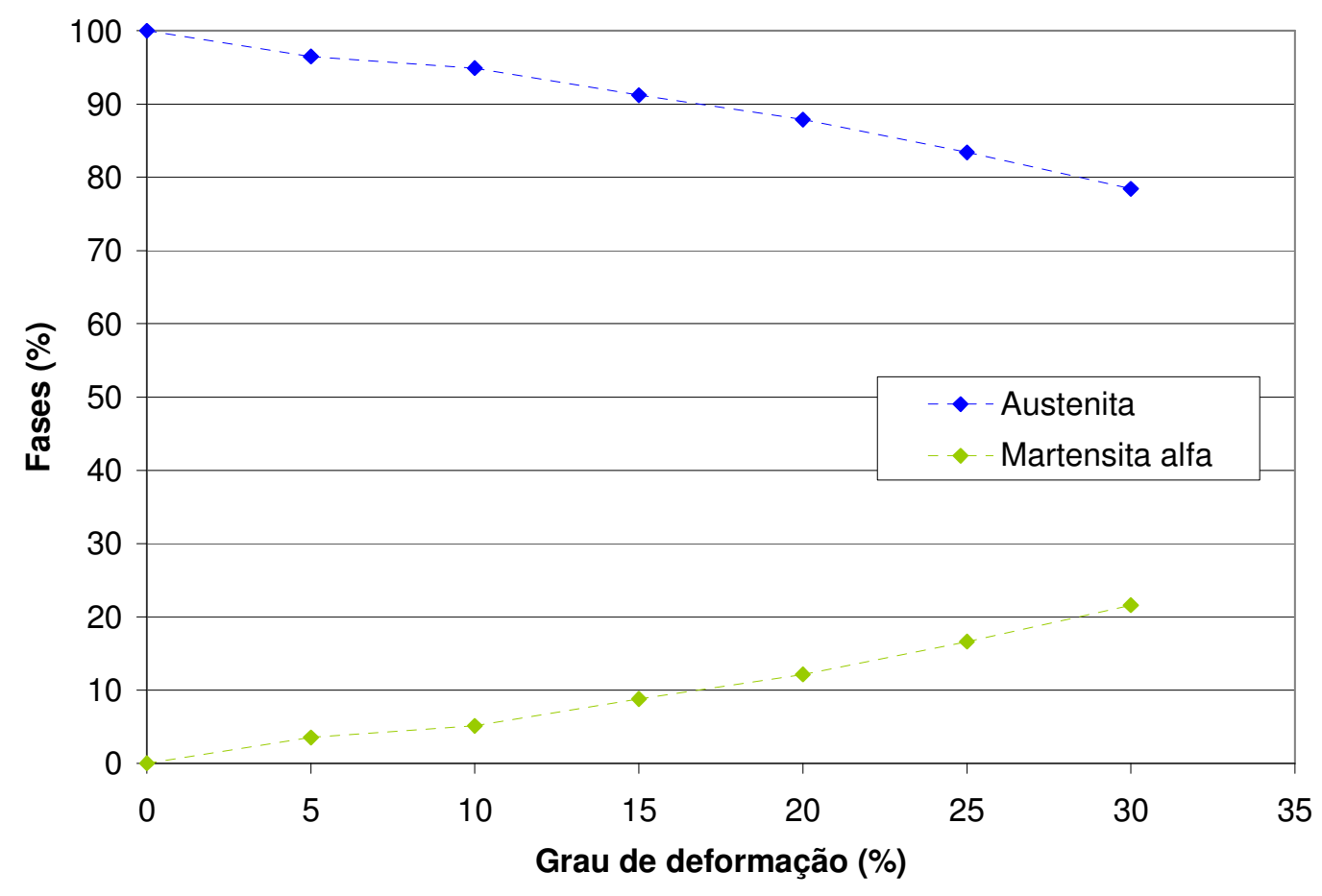

(a) 


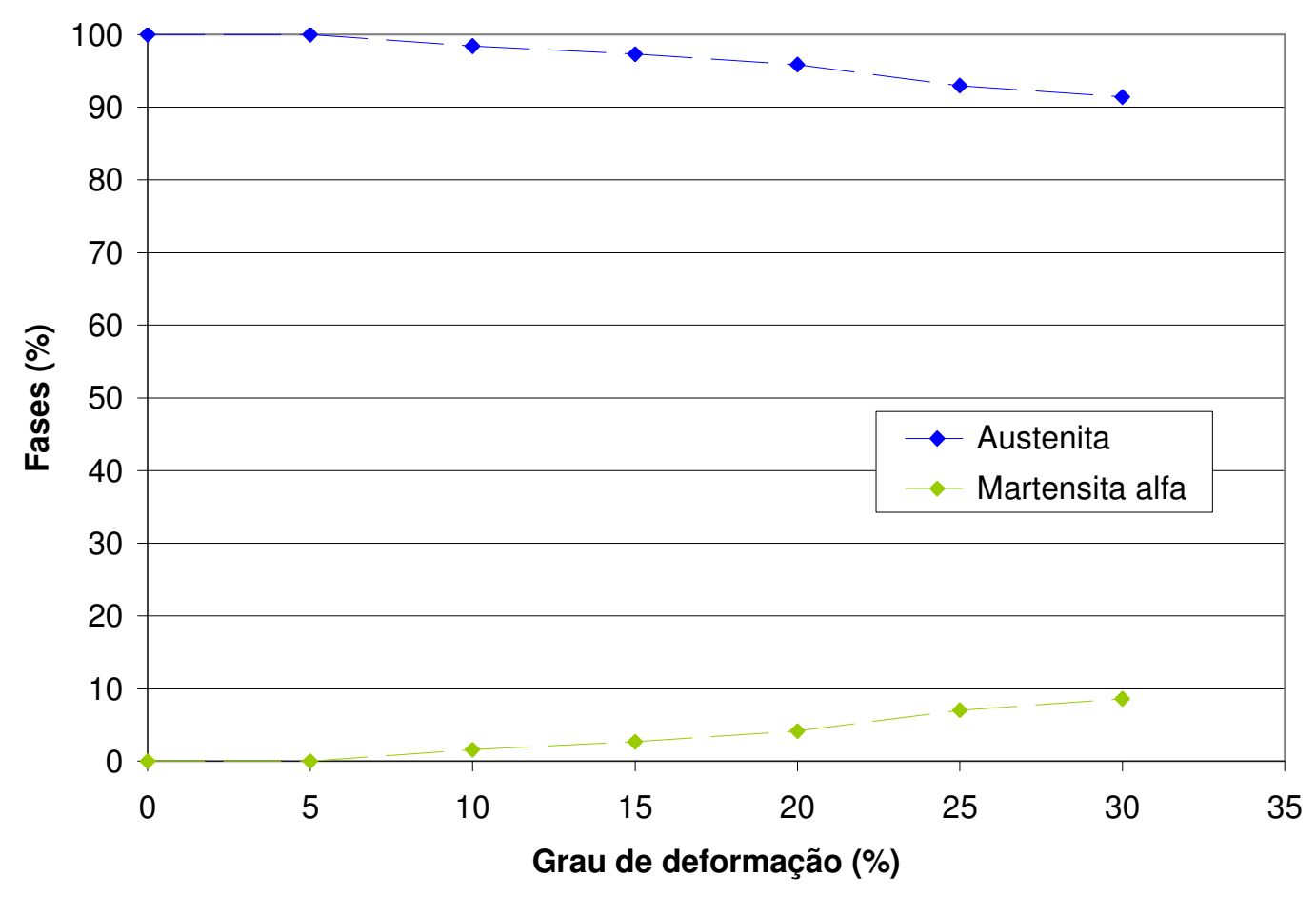

(b)

Figura 65 - Fração volumétrica de fases nos aços tracionados (a) AISI 201 e (b) AISI 304.

\subsubsection{Efeito da taxa de deformação}

Os ensaios de tração também foram realizados a fim de avaliar o efeito da velocidade de deformação na transformação de fase induzida por deformação. A figura 66 mostra o efeito da variação da velocidade de deformação no comportamento da curva tensão x deformação para os dois aços. 


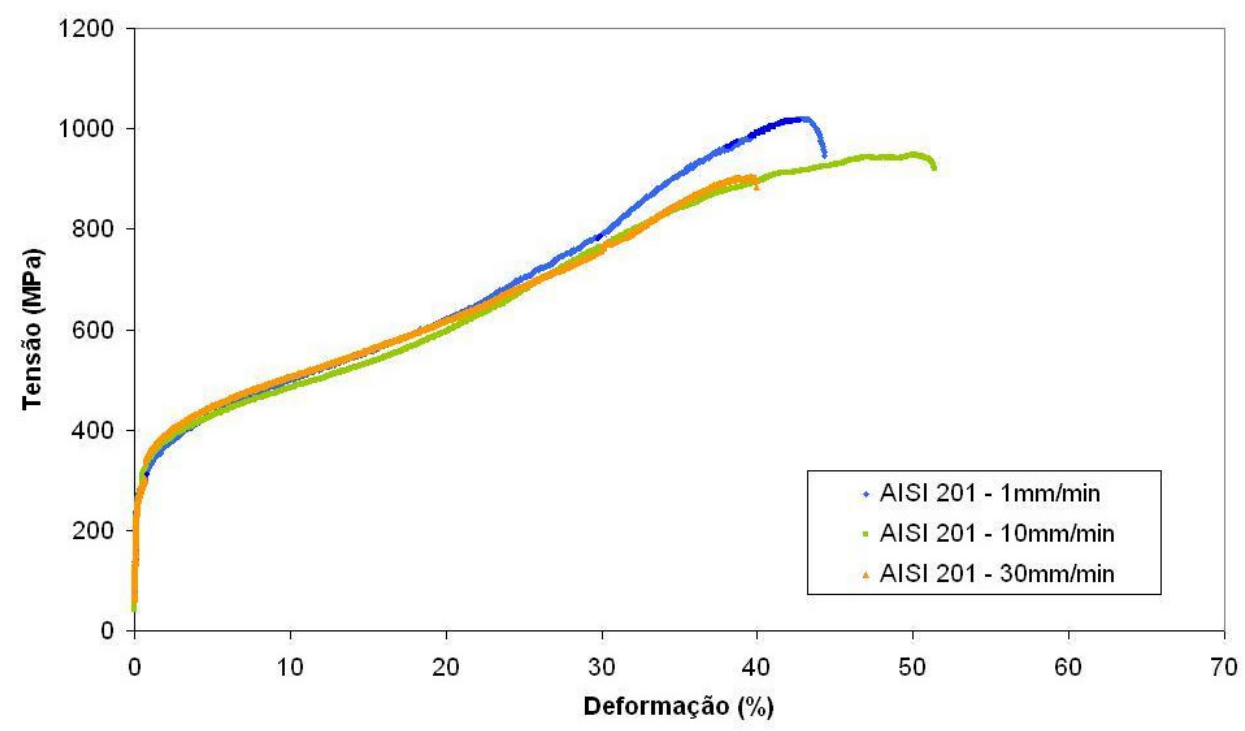

(a)

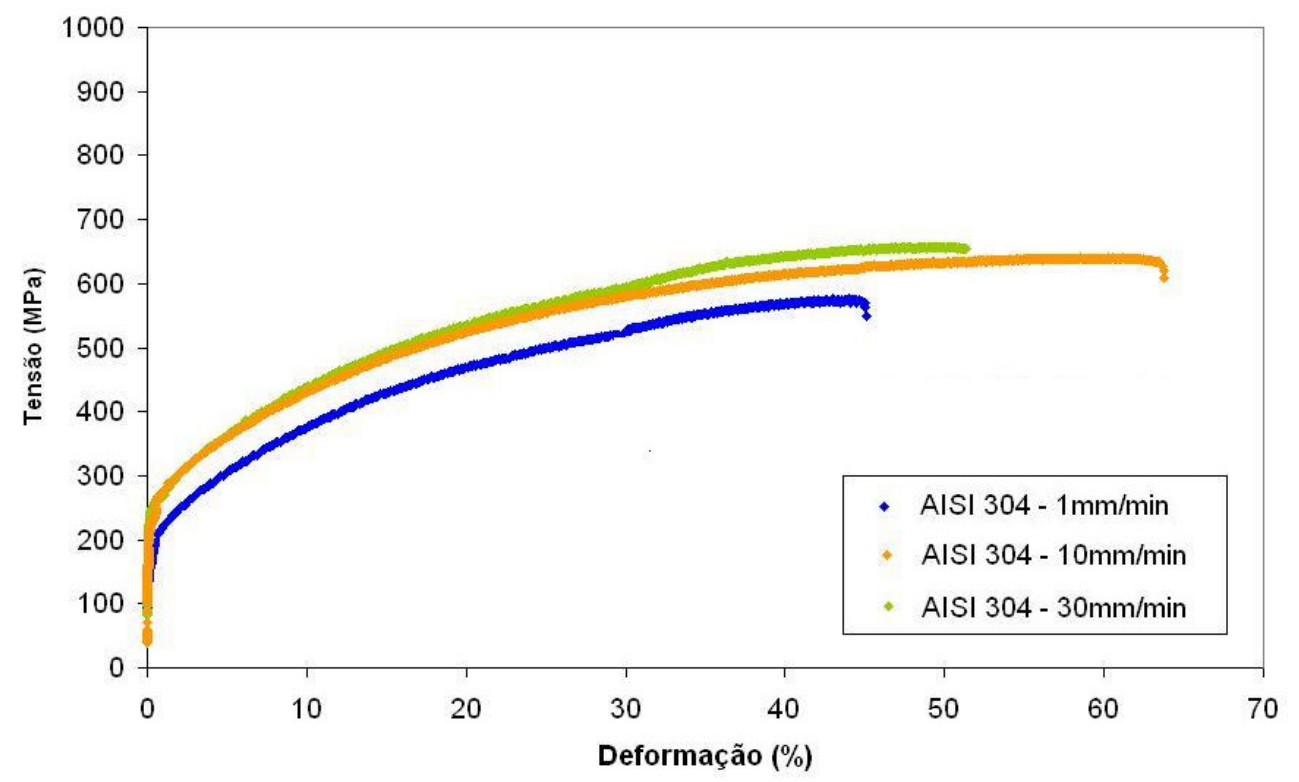

(b)

Figura 66 - Curva tensão $x$ deformação (de engenharia) em função da taxa da deformação (a) AISI 201 e (b) AISI 304.

O aço AISI 304 apresentou comportamento conforme esperado, ou seja, o aumento da taxa de deformação induz o aumento do endurecimento mais rapidamente, o que leva ao consequente aumento da resistência à tração [63]. O aço AISI 201 apresentou comportamento similar apenas para baixas deformações. No entanto, a tendência é reversa para deformações maiores, acima de $30 \%$, onde a tira tracionada com a menor velocidade de rampa $(1 \mathrm{~mm} / \mathrm{min})$ resultou em maior limite de resistência, ultrapassando todas as outras curvas. A hipótese mais provável que justifica este comportamento é que baixas deformações impostas a um corpo de prova durante um teste de tração dificilmente gera aquecimento do mesmo e a 
transformação de fase induzida pela deformação acontece. No entanto, a temperatura não foi medida experimentalmente durante os ensaios. Quando o corpo de prova é submetido a elevadas taxas de aquecimento, pode haver o aquecimento do corpo de prova, aumentando a estabilidade da austenita dificultando a transformação de fase induzida por deformação. Além disso, a EDE aumenta com a temperatura, o que leva a redução da densidade de discordância e falhas de empilhamento, bandas de escorregamento, em que todos servem de nucleação para martensita induzida por deformação. Dessa forma, o comportamento inverso do aço AISI 201 para baixas taxas de deformação é facilmente explicável. Comportamento similar também foi apontado por Lichtenfeld e co-autores [31] para o aço AISI 304L. Lichtenfeld e co-autores [31] confirmaram por meio de ensaio de tração que o limite de escoamento dos aços AISI 309 e AISI 304L aumenta com o aumento da taxa de deformação, de $1,25 \times 10^{-4}$ a $400 \mathrm{~s}^{-1}$. O limite de escoamento do aço AISI 304L aumentou de 300 para 480 MPa para a maior taxa de deformação, enquanto o limite de resistência diminuiu de 755 para $646 \mathrm{MPa}$. A queda do valor do limite de resistência é devido ao aquecimento do corpo de prova causado pela elevada taxa de deformação. O calor gerado pela deformação ficou retido no corpo de prova, o que causou a inibição da transformação de fase.

O aumento do limite de resistência com o aumento da taxa de deformação é mais evidente para o aço AISI 304. No aço AISI 201 as curvas ficam muito próximas, apesar de todos os aços terem sido testados nas mesmas condições.

\subsubsection{Efeito do modo de deformação}

Como já foi discutido anteriormente, dois processo de conformação a frio foram utilizados para avaliar o efeito do modo de deformação na transformação de fase induzida por deformação. Os mesmos aços foram ensaiados por tração e laminação a frio para análise comparativa das fases formadas. A análise de DRX evidenciou que houve formação da fase martensita- $\varepsilon$ para baixas deformações apenas nas amostras laminadas. No entanto, houve formação de maior quantidade de martensita- $\alpha$ ' para o aço AISI 201 tracionado.

As tiras de aço que foram tracionadas com a mesma taxa de deformação de $10 \mathrm{~mm} / \mathrm{min}$ tiveram comportamento muito similar e mesma tendência de crescimento 
da dureza com o aumento do grau de redução, conforme indica a figura 67. Mesmo aplicando a mesma taxa de deformação para ambos os processos (laminação e ensaio de tração), o aumento da dureza não progrediu da mesma forma. As tensões envolvidas no processo de laminação são distintas das tensões num ensaio de tração e, em geral, mais elevadas. A diferença de tensão aplicada ao material pode estar relacionada à diferença de dureza obtida entre as amostras laminadas e tracionadas.

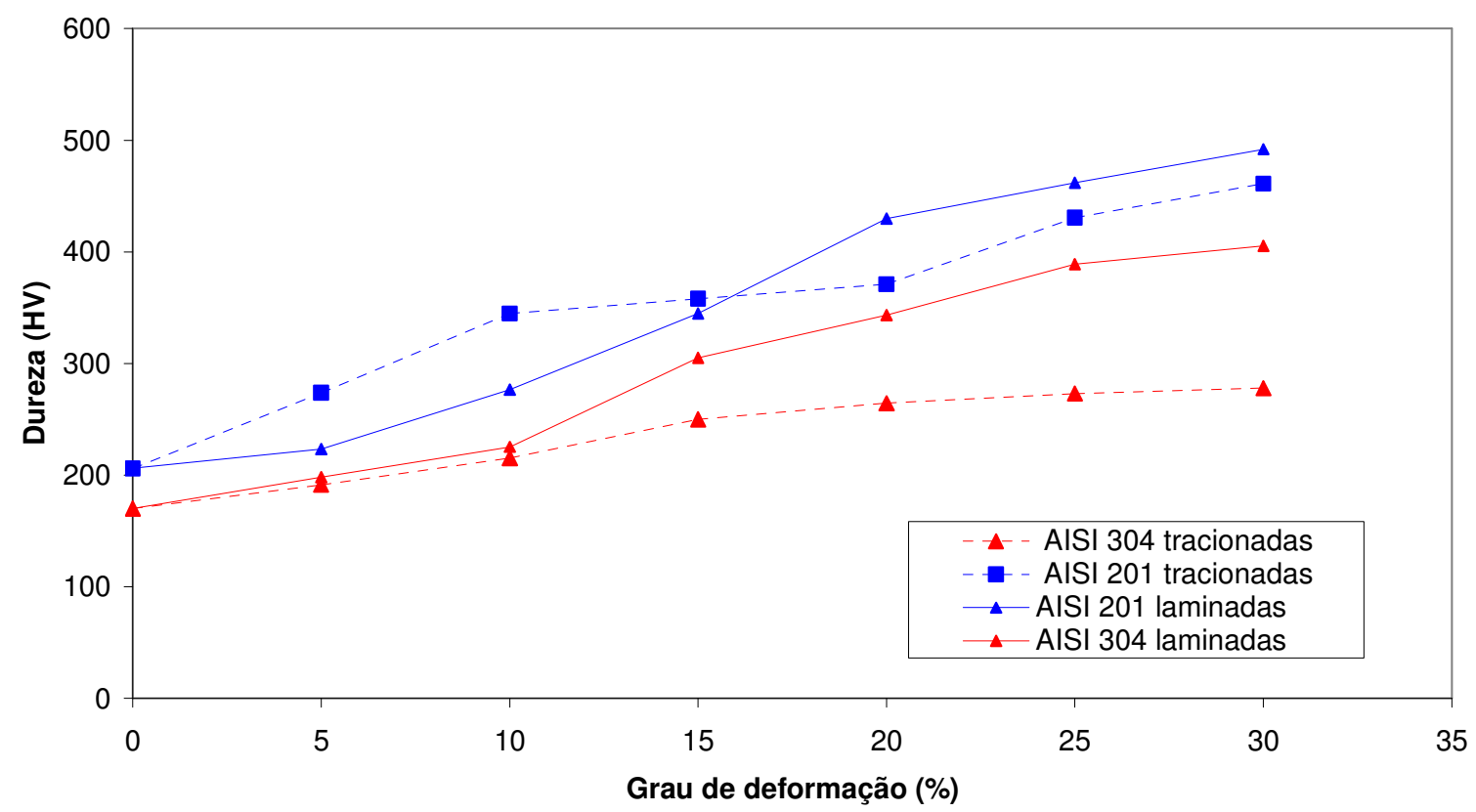

Figura 67 - Dureza dos aços AISI 201 e AISI 304 laminados e tracionados em função do grau de deformação.

Mesmo utilizando a mesma taxa de deformação para os dois processos de conformação a frio, $10 \mathrm{~mm} / \mathrm{min}$, em geral as tiras dos aços AISI 201 e AISI 304 apresentaram comportamentos distintos. As tiras dos dois aços laminadas apresentaram maior encruamento que as tiras que foram tracionadas. Possivelmente, há uma razão para este tipo de acontecimento. Em ensaio de tração ocorre um gradiente de deformação e velocidade de deformação ao longo da tira que está sendo tracionada, causando um considerável gradiente de temperatura. Da mesma forma que já foi discutido anteriormente o efeito da temperatura na transformação de fase induzida por deformação, se há elevação de temperatura durante o ensaio de tração, a transformação de fase induzida por deformação é retardada. Esta ocorrência pode justificar a menor dureza das tiras do aço AISI 304 que foram tracionados em relação às tiras que foram laminadas. O material AISI 304 
mostrou-se mais sensível à diferença de modo de conformação a frio do que o material AISI 201. As análises de medidas magnéticas realizadas com auxílio do ferritoscópio praticamente apresentaram a mesma porcentagem de fase magnética para as tiras de aço AISI 201 laminadas e tracionadas. Houve maior discrepância de resultados para o aço AISI 304, sendo que as tiras laminadas deste aço apresentaram maior porcentagem de fase magnética do que as tiras tracionadas. As medidas de dureza também confirmam esta diferença.

Ao contrário das tiras dos aços laminadas, as tiras tracionadas não apresentaram formação da fase martensita- $\varepsilon$, nem mesmo para as menores deformações aplicadas.

\subsection{Reversão da martensita}

Uma série de tratamentos térmicos foi realizada para o mapeamento da reversão da martensita dos materiais AISI 201 e AISI 304 previamente laminados com 30\% de redução. Como já discutido anteriormente, na literatura há comprovação de que a faixa de temperaturas que ocorre a reversão da martensita $\varepsilon$ é diferente e inferior à faixa de temperatura que ocorre a reversão da martensita- $\alpha$ '. As amostras foram tratadas pelo período de 1 hora em temperaturas de 400 a 700 ${ }^{\circ} \mathrm{C}$ com intervalo de $50{ }^{\circ} \mathrm{C}$. Após tratamento térmico, as amostras foram cortadas e embutidas para avaliação de micro-dureza.

Os resultados podem ser vistos na figura 68. As durezas dos dois materiais a $400{ }^{\circ} \mathrm{C}$ mantiveram praticamente a mesma em comparação a dureza após conformação. Como este estudo de reversão da martensita foi realizado nas amostras com deformação máxima, ou seja, previamente laminadas com $30 \%$ de redução, não era esperado que houvesse queda de dureza após tratamento térmico em temperaturas mais baixas $\left(400{ }^{\circ} \mathrm{C}\right)$, pois a análise de $\mathrm{DRX}$ comprovou que não houve formação de martensita- $\varepsilon$ para graus de deformação elevados. Só foi observada queda de dureza a partir de $550{ }^{\circ} \mathrm{C}$ para o aço AISI 201. No intervalo de temperatura de 500 a $700{ }^{\circ} \mathrm{C}$ a dureza caiu cerca de $150 \mathrm{HV}_{0,1}$, chegando próximo de $350 \mathrm{HV}_{0,1}$ quando tratado a $700^{\circ} \mathrm{C}$. Provavelmente, se o aço AISI 201 fosse tratado em temperaturas maiores que $700^{\circ} \mathrm{C}$, o material atingiria dureza típica de 
material recozido, por volta de $200 \mathrm{HV}$. De maneira geral, a temperatura de reversão da martensita é pouco sensível ao tipo do aço, a taxa de deformação e ao efeito do tratamento térmico realizado antes da conformação a frio [32, 50]. A literatura afirma que a reversão da martensita induzida por deformação ocorre em temperaturas bem abaixo da temperatura de recristalização [32]. Há indícios de que a reversão da martensita pode ocorrer por meio de um mecanismo de cisalhamento sem depender da temperatura, seguido de e um mecanismo difusional isotérmico [56, 70]. No entanto, Stalder e co-autores [126] apresentam opinião distinta, pois afirmam que a cinética da reversão da martensita depende da temperatura e do tempo e segue a equação de Johnson-Mehl-Avrami-Kolmogorov (JMAK).

As técnicas mais recomendadas para avaliar a reversão da martensita induzida por deformação são as análises de DRX e medidas magnéticas (ferritoscópio). No entanto, neste trabalho foram adotadas as medidas de microdureza para avaliar o comportamento dos aços após cada temperatura de tratamento térmico, assim como Singh [56].

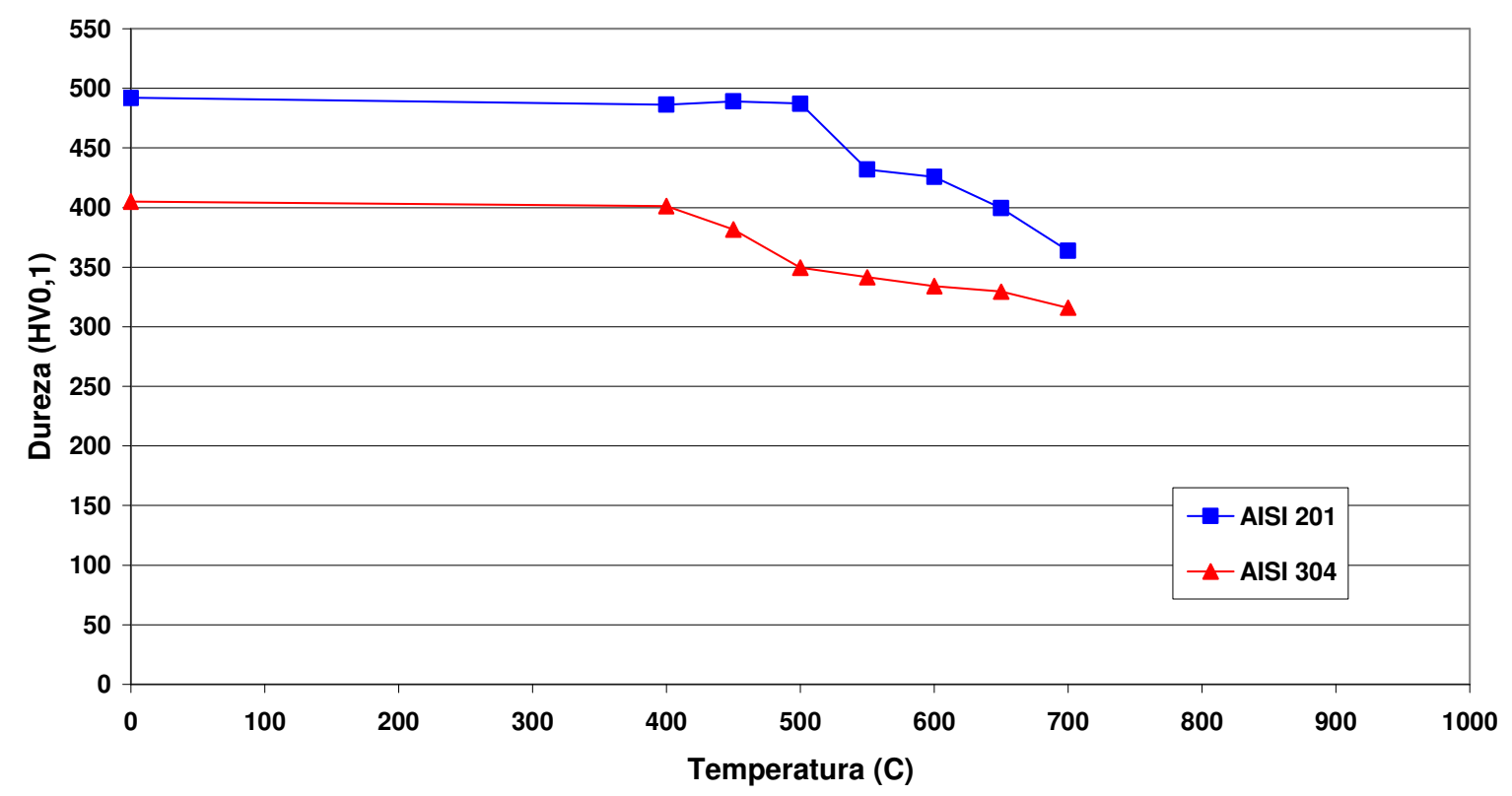

Figura 68 - Curva experimental da reversão da martensita para os aços AISI 201 e AISI 304 a partir de amostras laminadas em $30 \%$ de redução.

O aço AISI 304 apresentou queda de dureza a partir de $450{ }^{\circ} \mathrm{C}$ e houve queda de dureza gradativa conforme a temperatura de tratamento térmico aumentou. 
Ambos os materiais apresentam comportamento semelhante ao publicado por Mészáros e Prohászka [57]. 


\section{Conclusões}

Em seguida são sumarizadas as principais conclusões desta dissertação:

- A fração volumétrica de martensita- $\alpha$ ' aumentou continuamente com o aumento da redução aplicada por laminação a frio para os aços AISI 201 e AISI 304;

- O aço AISI 201 apresenta maior susceptibilidade para ocorrência da transformação de fase induzida por deformação em comparação ao aço AISI 304;

- A análise de DRX mostrou-se eficaz para a caracterização das fases envolvidas na transformação de fase induzida por deformação para os aços AISI 201 e AISI 304;

- Por meio da análise de DRX foi possível acompanhar a ocorrência de martensita- $\varepsilon$ e martensita- $\alpha$ principalmente durante as reduções iniciais de 5 a $15 \%$;

- A análise quantitativa obtida por meio de DRX da fase martensita- $\alpha$ foi bastante similar ao resultado obtido por meio de ferritoscópio;

- Os ensaios de espectroscopia de impedância eletroquímica mostraram que ambos os AlAs apresentam comportamentos similares quanto à resistência à corrosão. No entanto, o aço AISI 304 possui valores de capacitância e de impedância superiores aos do aço AISI 201;

- Os ensaios de polarização potenciodinâmica anódica mostraram que os dois materiais têm potenciais de corrosão da ordem de $10^{-8} \mathrm{~A} / \mathrm{cm}^{2}$, típico de materiais passivos. Porém, o aço AISI 201 possui maior resistência à corrosão do que o aço AISI 304, devido ao maior potencial de quebra;

- O aço AISI 304 apresentou uma grande quantidade de pites de diâmetros aproximados de $100 \mu \mathrm{m}$, enquanto o aço AISI 201 sofreu corrosão localizada apenas nas regiões onde haviam estrias causadas pelo processo de laminação das amostras;

- O aço AISI 201 é recomendado para substituir o aço AISI 304 na aplicação em espaçadores de anel de 3 peças devido à uma séries de faotres como: melhores propriedades mecânicas avaliadas por meio de ensaio de tração, ao 
seu menor custo, à maior susceptibilidade a transformação de fase do aço AISI 201 em relação ao aço AISI 304 e à similaridade da resistência à corrosão dos dois aços. 


\section{REFERÊNCIAS}

[1] LO, K.H.; SHEK, C.H.; LAI, J.K.L.; Recent developments in stainless steels, Materials Science and Engineering R, v. 65, p.39-104, Apr. 2009.

[2] ACESITA. Inox na arquitetura - Inox a estrela do seu próximo projeto. Acesita, fevereiro 2007. Disponível em http://www.acesita.com.br/port/produtos_servicos. Acesso em 25.abril.2010.

[3] DAVIS, J. R., ed. ASM International Handbook. Specialty Handbook: Stainless Steels. Materials Park, ASM International, 1994. p. 22

[4] VLACK, L.H.V.; Princípios de Ciência dos materiais, Edgard Blücher LTDA, São Paulo, p.342, 1970.

[5] Disponível em: www.worldstainless.org. Acesso em 11.outubro.2009.

[6] SILVA, A.L.V.C.; MEI, P.R.; Aços e Ligas Especiais, $2^{\circ}$ ed., São Paulo, Edgard Blücher, 2006, p. 408-409.

[7] DAVIS, J. R., ed. ASM International Handbook. Specialty Handbook: Stainless Steels. Materials Park, ASM International, 1994. p. 13

[8] SCHAEFFLER, A.L., Constitution diagram for stainless steel weld metal. Metal Progress, v. 56, n.11, p.680-680B, 1949.

[9] HONEYCOMBE, R.W.K., BHADESHIA, H.K.D.H., Metallurgy and Materials Science series. Steels Microstructure and Properties. $2^{\circ}$ ed. Edward Norton, $p$. 254-255, 1995. 
[10] DeLONG W. T. A modified phase diagram for stainless steel weld metals. Metal Progress, v. 77, p. 98-100 e 100B, 1960.

[11] HULL F. C. Delta ferrite and martensite formation in stainless steel. Welding Journal, v. 52, p.193s-203s, May 1973.

[12] WASHKO, S.D., AGEEN, G. Wrought Stainless Steels. In: METALS

HANDBOOK Properties and Selection: Irons, Steel and High-Performance Alloys.

10. ed. Materials Park, Ohio; ASM International, 1990. v. 1, p. 899.

[13] PADILHA, A.F.; GUEDES, L.C.; Aços inoxidáveis austeníticos Microestrutura e Propriedades. Hemus, São Paulo, p.33, 1994.

[14] DAVIS, J. R., ed. ASM International Handbook. Specialty Handbook: Stainless Steels. Materials Park, ASM International, 1994. p. 20

[15] SILVA, A.L.V.C.; MEI, P.R.; Aços e Ligas Especiais, $2^{\circ}$ ed., Edgard Blücher, São Paulo, 2006, p. 417.

[16] PADILHA, A.F.; RIOS, P.R.; Decomposition of austenite in austenitic stainless steels. ISIJ International, v. 42, n. 4, p. 325-337, 2002.

[17] ECKSTEIN H. J. Korrosionsbeständige Stähle Leipzig, Alemanha, Deutscher Verlag für Grundstoffindustrie GmbH, 1990, p.21.

[18] SPEICH G. R. Constitution of ternary alloys Cr-Fe-Ni. In: Metals Handbook: Metallography and Microstructures. $8^{\circ}$ ed. Materials Park, ASM, 1973. p.424-426.

[19] New 200 series steels - An opportunity or a threat to the image of 
stainless steel? Belgium, ISSF, November 2005, 14p. Disponível em: $<$ www.worldstainless.org $>$. Acesso em 01.dezembro.2009.

[20] Disponível em: www.manganese.org/about mn/application. Acesso em 28.fevereiro.2010.

[21] SIMMONS, J.W.; Overview: high-nitrogen alloying of stainless steels. Materials Science and Engineering A, v. 207, p. 159-169, 1996.

[22] Disponível em: www.infomine.com. Acesso em 22.abril.2010.

[23] CHARLES, J., The new 200 series - an alternative answer to $\mathrm{Ni}$ surcharge? Dream of nightmare? PROCEEDING OF THE FIFTH STAINLESS STEEL SCIENCE AND MARKET CONGRESS, Sevilla, 2005. p. 1-9. Disponível em: $<$ www.euro-inox.org $>$. Acesso em 11.outubro.2009.

[24] VOGGENREITER, G. et al. Immuno-inflammatory tissue reaction to stainlesssteel and titanium plates used for internal fixation of long bones. Biomaterials, v. 24, p. 247-254, 2003.

[25] Safe Use of Nickel in the Workplace. 3 ed. Incorporating European Nickel Risk Assessment Outcomes. Nickel Institute. 2008. 124p. Disponível em: $<$ www.centroinox.it $>$. Acesso em 24.abril.2010.

[26] SUMITA, M.; HANAWA, T.; TEOH, S.H.; Development of nitrogen-containing nickel-free austenitic stainless steels for metallic biomaterials - review. Material Science and Engineering C, v. 24, p.753-760, 2004. 
[27] DAVIS, J. R., ed. ASM International Handbook. Specialty Handbook: Stainless Steels. Materials Park, ASM International, 1994. p. 25

[28] EICHELMAN, G.H.; HULL, F.C.; The effect of composition on the temperature of spontaneous transformation of austenite to martensite in 18-8 type stainless steels. Transactions of ASM, v. 45, p.77-104, 1953.

[29] ANGEL, T.; Formation of martensite in austenitic stainless steels. Journal of Iron and Steels Institute, v. 177, p.165-174, May 1954.

[30] MANGONON, P.L.; THOMAS, G.; Structure and properties of thermalmechanically treated 304 stainless steel. Metallurgical Transactions, v. 1, p.15871594, Jun. 1970.

[31] LICHTENFELD, J.A.; MATAYA, M.C.; VAN TYNE, C.J.; Effect of strain on the stress-strain behavior of alloy 309 and $304 \mathrm{~L}$ austenitic stainless steel. Metallurgical and Materials Transactions A, v. 37, p.147-161, Jan. 2006.

[32] PADILHA, A.F.; PLAUT, R.L.; RIOS, P.R.; Annealing of cold-worked austenitic stainless steels, ISIJ International, v. 43, n. 2, pp.135-143, 2003.

[33] HAE $\beta N E R$, F.; PLAUT, R.L.; PADILHA, A.F.; Separation of static recrystallization and reverse transformation of deformation-induced martensite in an austenitic stainless steel by calorimetric measurements. ISIJ International, v. 43, n. 9, p.1472-1474, 2003.

[34] PADILHA, A.F.; SICILIANO, F.Jr. Encruamento, recristalização, crescimento de grão e textura, $3^{\circ}$ ed., ABM, São Paulo, 2005, p.13. 
[35] PADILHA, A.F.; Materiais de engenharia - microestrutura e propriedades. Hemus, p. 171-172, 2000.

[36] FANG, X.F.; DAHL, W.; Strain hardening transformation mechanism of deformation-induced martensite transformation in metastable austenitic stainless steels. Materials Science and Engineering A, v. 141, p. 189-198, 1991.

[37] PADILHA, A.F.; Materiais de engenharia - microestrutura e propriedades. Hemus, p.186-189, 2000.

[38] PINTO, H.; Effect of temperature and environment on the deformation mechanisms of austenitic steels during cryogenic wear, $1 \mathrm{v}$. Tese (Doutorado) Technische Universität Berlin, Berlin, Germany, 2005, p. 53.

[39] TAVARES, S.S.M. et al. Deformation induced martensitic transformation in a 201 modified austenitic stainless steel, Material Characterization, v. 60, p.907 $911,2009$.

[40] SCHRAMM, R.E.; REED, R.P.; Stacking Fault Energies of seven commercial austenitic stainless steels. Metallurgical Transactions A, v. 6A, p.1345-1351, Jul. 1975 .

[41] CHOI, J.Y.; JIN, W.; Strain induced martensite formation and its effect on strain hardening behavior in the cold drawn 304 austenitic stainless steels. Scripta Materialia, v. 36, n.1, p. 99-104, 1997.

[42] BAIN, E.C.; PAXTON, H.W.; Alloying elements in steel. $2^{\circ}$ ed. Metals Park, Ohio, ASM, p.6-7, 1966.

[43] VITOS, L., NILSSON, J.O., JOHANSSON, B.; Alloying effects on the stacking energy in austenitic stainless steels from first-principles theory. Acta Materialia, v. 54, p.3821-3826, 2006. 
[44] GAVRILJUK, V.; PETROV, YU.; SHANINA, B.; Effect of nitrogen on the electron structure and stacking fault energy in austenitic steels. Scripta Materilia, v. 55, p.537-540, 2006.

[45] SILVA, A.L.V.C.; MEI, P.R.; Aços e Ligas Especiais, $2^{\circ}$ ed, São Paulo, Edgard Blücher, 2006, p. 215-220.

[46] HONEYCOMBE, R.W.K., BHADESHIA, H.K.D.H., Metallurgy and Materials Science series. Steels microstructure and properties, $2^{\circ}$ ed. Edward Norton, 1984, p 62-64.

[47] TALONEN, J. et al. Effect of strain rate on the strain-induced $\gamma \rightarrow \alpha^{\prime}$-martensite transformation and mechanical properties of austenitic stainless steel. Metallurgical and Materials Transactions A, v. 36, p.421-432, Feb. 2005.

[48] KHATAK, H.S.; RAJ B.; Corrosion of austenitic stainless steels: Mechanism, mitigation and monitoring. Materials Park, ASM International, 2002, p.19-26.

[49] DEIGHTON, M. Solubility of $\mathrm{M}_{23} \mathrm{C}_{6}$ in typre 316 stainless steel. Journal of the Iron and Steel Institute, v. 208, p.1012-1014, Nov.1970.

[50] MARTINS, L.F.; PLAUT, R.L.; PADILHA, A.F.; Effect of carbon on the coldworked state and annealing behavior of two $18 \% \mathrm{Cr}-8 \% \mathrm{Ni}$ austenitic stainless steels. ISIJ international, v. 38. n.6, p.572-579, 1998.

[51] REED, R.; Nitrogen in Austenitic Stainless Steels. JOM, p.16-21, Mar. 1989.

[52] SPEIDEL, M.O.; PEDRAZZOLI, R.M.; High nitrogen stainless steels in chloride solutions, Materials Performance, v. 31, n. 9, p. 59-62, 1992. 
[53] CHOI, J.Y.; JIN, W.; Effect on strain hardening behavior in the cold drawn 304 austenitic stainless steels. Scripta Materialia, v. 36, n. 1, p. $99-104,1997$.

[54] KIM, J.H., et al; The effects of nickel and carbon concentrations on the wear resistance of Fe-Ni-C austenitic alloys, Wear, v. 266, p.1137-1140, 2009.

[55] TERADA, M. Corrosão de aços inoxidáveis avançados em meios fisiológicos. Tese (doutorado). Instituto de Pesquisas Energéticas e Nucleares, São Paulo, 2008.

[56] SINGH, J.; Influence of deformation on the transformation of austenitic stainless steels. Journal of Materials Science, v. 20, p.3157-3166, 1985.

[57] PADILHA, A.F.; GUEDES, L.C.; Aços inoxidáveis Austeníticos: Microestrutura e Propriedades. Hemus, 1994, p.112-114.

[58] NAGY, E. et al. Deformation induced martensitic transformation in stainless steels. Materials Science and Engineering A, v. 378, p. 308-313, 2004.

[59] SPENCER, K. et al. Strengthening via the formation of strain-induced martensite in stainless steel. Materials Science and Engineering A, v. 387-389, p.873-881, 2004.

[60] TOURKI, Z.; BARGUI, H.; SIDHOM, H.; The kinetic of induced martensitic formation and its effect on forming limit curves in the AISI 304 stainless steel. Journal of Materials Processing Technology, v. 166, p. 330-336, 2005.

[61] BYUN, T.S.; HASHIMOTO, N.; FARRELL, K.; Temperature dependence of strain hardening and plastic instability behavior in austenitic stainless steels. Acta Materialia, v. 52, p. 3889-3899, 2004. 
[62] MÉSZÁROS, I.; PROHÁSZKA, J.; Magnetic investigation of the effect of $\alpha$ ' martensite on the properties of austenitic stainless steel. Journal of Materials Processing Technology, v. 161, p.162-168, 2005.

[63] DIETER, G.E.; Mechanical Metallurgy, $2^{\circ}$ ed., New York McGraw Hill, 1976, p. 348-350.

[64] HEDAYATI, A. et al. The effect of cold rolling regime on microstructure and mechanical properties of AISI 304L stainless steel. Journal of Materials Processing Technology, v. 210, p. 1017-1022, 2010.

[65] SEMIATIN, S.L.; JONAS, J.J.; Formability \& Workability of Metals: Plastic Instability \& Flow Localization. Metals Park, Ohio, American Society for Metals. 1984, p. 17-18.

[66] SOUZA, S.A.; Ensaios mecânicos de materiais metálicos. São Paulo, Edgard Blücher Ltda, 1974, p.49.

[67] LECROISEY, F.; PINEAU, A.; Martensitic transformation induced by plastic deformation in the Fe-Ni-Cr-C system. Metallurgical Transactions, v. 3, p. 387-396, Feb. 1972.

[68] BOWKETT, M.W.; KEOWN, R.; HARRIES, D.R; Quench and deformationinduced structures in two austenitic stainless steels. Metal Science, v. 16, p.499-506, Nov. 1982.

[69] MANGONON, P.L.; THOMAS, G.; The martensite phases in 304 stainless steel, Metallurgical Transactions, v. 1, p.1578-1586, Jun. 1970.

[70] TAVARES, S.S.M, FRUCHART, D.; MIRAGLIA, S.; A magnetic study of the reversion of martensite- $\alpha$ in a 304 stainless steel. Journal of alloys and compounds, v. 307, p. 311-337, Mar. 2000. 
[71] TAVARES, S.S.M. et al. Phase transformation induced by severe plastic deformation in the AISI 304 stainless steel. Materials Science and Engineering A, v. 358, p.32-36, 2003.

[72] MILAD, M. et al. The effect of cold work on structure and properties of AISI 304 stainless steel. Journal of Materials Processing Technology, v. 203, p. 80-85, 2008.

[73] HUMBERT, M. et al. Analysis of the $\gamma-\varepsilon-\alpha$ ' variant selection induced by $10 \%$ plastic deformation in 304 stainless steel at $-60^{\circ} \mathrm{C}$. Materials Science and Engineering A, v. 454-455, p. 508-517, 2007.

[74] MARSHALL, P. Austenitic Stainless Steels - Microstructure and properties, Elsevier applied Science publishers, p.23-29, 1984.

[75] SEETHARAMAN, V.; KRISHNAN, R.; Influence of the martensítica transformation on the deformation behavior of an AISI 316 stainless steel at low temperatures. Journal of Materials Science, v. 16, p.523-530, 1981.

[76] BROOKS, J.W.; LORETTO, M.H.; SMALLMAN, R.E.; Direct observation of martensite nuclei in stainless steel. Acta Materialia, v. 27, p. 1839-1847, 1979.

[77] HONEYCOMBE, R.W.K., BHADESHIA, H.K.D.H., Metallurgy and Materials Science series. Steels Microstructure and Properties. $2^{\circ}$ ed. London, Edward Norton, 1995. p.274-277.

[78] SUZUKI, T. et al; Plastic deformation and martensitic transformation in an ironbase alloy. Scripta Metallurgica, v. 10, p.353-358, Feb. 1976.

[79] SUZUKI, T.; An experimental study of the martensite nucleation and growth in 
18/8 stainless steel. Acta Metallurgica, v. 25, p.1151-1162, Jan. 1977.

[80] REED, R.P.; The spontaneous martensitic transformations in $18 \% \mathrm{Cr} \% \mathrm{Ni}$ steels. Acta Metallurgica, v. 10, p.865-877, Sep. 1962.

[81] HERRERA, C., Estudo dos fenômenos que ocorrem durante o recozimento dos aços inoxidáveis austeníticos 304L e 316L deformados em várias temperaturas. Tese (Doutorado), Escola Politécnica, Universidade de São Paulo, São Paulo, 2006.

[82] TAVARES, C.F.; Influência da composição química e da espessura da peça fundida na quantidade e distribuição de ferrita delta em aços inoxidáveis austeníticos. Dissertação (Mestrado). Escola Politécnica, Universidade de São Paulo, São Paulo, 2009.

[83] HELMUT FISCHER GmbH+Co.KG. Ferritoscópio modelo MP30E, Catálogo. 2006.

[84] DATE, H.; Simple estimation of deformation-induced martensite in stainless steel. Key Engineering Materials, v. 297-300, p.500-506, Nov. 2005.

[85] DE, A.K. et al. Quantitative measurement of deformation-induced martensite in 304 stainless steel by X-ray diffraction. Scripta Materialia, v. 50, p.1445-1449, 2004.

[86] PADILHA, A.F.; SICILIANO, F.Jr.; Encruamento, recristalização, crescimento de grão e textura, $3^{\circ}$ ed. São Paulo, ABM, 2005. p.176.

[87] VILELA, J.M.C.; MORAES, J.M.D.; ANDRADE, M.S.; Transformações de fases em aço inoxidável austenítico estudadas por calorimetria exploratória diferencial. In: Congresso Anual da ABM, 60, Belo Horizonte, ABM, 2005,Anais, 
$10 p$.

[88] LIU, Y.; Mechanistic simulation of deformation-induced martensite stabilization. Materials Science and Engineering A, v. 378, p.459-464, 2004.

[89] SHAIRA, M. et al. Evaluation of the strain induced martensitic transformation by acoustic emission monitoring in 304L austenitic stainless steel: Identification of the $A E$ signature of the martensite transformation and power-law statistics. Materials Science \& Engineering A, v. 492, p. 392-399, 2008.

[90] BONTCHEVA, N. et at. Finite element simulation of strain induced austenitemartensite transformation and fine grain production in stainless steel. Computational Materials Science, v. 40, p.90-100, 2007.

[91] GUTKIN, M.Y. et al. Dislocation-disclination model of heterogeneous martensite nucleation in transformation-induced plasticity steels. Metallurgical and Materials Transactions A, v. 33, p 1351-1362, May 2002.

[92] MAZZONI-LEDUC, L.; PARDOEN, T.; MASSART, T.J.; Strain gradient plasticity analysis of transformation induced plasticity in multiphase steels. International Journal of Solids and Structures, v. 45, p.5397-5418, 2008.

[93] PETIT, B. et at. Deformation behavior and microstructure/texture evolution of an annealed 304 AISI stainless steel sheet. Experimental and micromechanical modeling. International Journal of Plasticity, v. 23, p.323-341, 2007.

[94] MORI, T. et al. Micromechanics of stress-induced martensitic transformation. Materials Science and Engineering A, v. 378, p.479-483, 2004.

[95] MISRA, R.D.K, et al. Microstructure and deformation behavior of phasereversion induced nanograined / ultrafine-grained austenitic stainless steel. 
Metallurgical and Materials Transactions A, v. 40, p. 2498-2509, Oct. 2009.

[96] SHABASHOV, V.A.; Nanostructure formation and phase transformations in nitrided stainless steel Kh18N8 during severe cold deformation. The Physics of Metals and Metallography, v. 107, n. 6, p. 601-612, 2009.

[97] LEE, J.B.; Effects of alloying elements $\mathrm{Cr}$, Mo, $\mathrm{N}$ on repassivation characteristics of stainless steels using the abrading electrode technique. Material Chemistry and Physics, v. 99, n. 2-3, p. $224-234$, Oct. 2006.

[98] GE, H.; ZHOU, G; WU, W.; Passivation model of 316 stainless steel in simulated cooling water and the effect of sulfide on the passive film. Applied Surface Science, v. 211, n. 1-4, p. 321-334, 2003.

[99] OH, K.T. et al. Properties of super stainless steels for orthodontic applications, Journal of Dental Research, v. 80, n.4, p. 183-194, 2001.

[100] HAKIKI, N.E. et al. The electronic structure of passive films formed on stainless steels. Corrosion Science, v. 37, n. 11, p. 1809-1822, 1995.

[101] CZYRSKA, A.F. et al. Microscopy (AFM, TEM, SEM) studies of oxide scale formation on FeCrAl based ODS alloys. Solid State lonics, v. 117, pp.13-20, 1999.

[102] VANINI, A.S.; AUDOUARD, J.P.; MARCUS, P.; The role of nitrogen in the passivity of austenitic stainless steels. Corrosion Science, v. 36, n. 11, p.18251834, 1994. 
[103] HÄNINNEN, H. et al. Effects of processing and manufacturing of high nitrogen-containing stainless steels on their mechanical, corrosion and wear properties. Journal of Materials Processing Technology, v. 117, p. 424-430, 2001.

[104] BABA, H.; KODAMA, T.; KATADA, Y.; Role of nitrogen on the corrosion of austenitic stainless steel. Corrosion Science, v. 44, p.2393 -2407, 2002.

[105] WOLINECK,S.; Técnicas eletroquímicas em corrosão. Edusp, 2003, p. 79.

[106] ADVANTAGES OF NICKEL. Nickel in stainless steel. Nickel Institute, 2008. 52p. Disponível em: <www.centroinox.it $>$. Acesso em 24.abril.2010.

[107] TOMANIK, E.; Piston Ring Conformability in a Distored Bore. SAE paper 960356. 1996.

[108] PEREIRA, M.M.V.; BRUNO, R.A.; Low Width Oil Control Rings for SI engines. SAE paper 2007-01-2830. 2007.

[109] INTERNATIONAL ORGANIZATION FOR STANDARDIZATION. Internal combustion engines - piston rings. ISO 6621-3, Part 3: Material specifications. 2000. 
[110] CASTRO, C.S.B.; SALES, L.S.; GONZALES, B.M.; Envelhecimento de um aço inoxidável AISI 304 contendo martensita induzida por deformação. In:

Congresso CBECIMat, $17^{\circ}$, Foz do Iguaçu, Nov. 2006, Anais, 10p.

[111] WASHKO, S.D., AGEEN, G.; Wrought stainless Steels. In: Metals Handbook: Properties and Selection: Irons, Steel and High-Performance Alloys. 10.ed. Materials Park, Ohio, ASM International, 1990. v.1, p. 842.

[112] JOHNSON,C.A.; Metallography: Principles and Procedures, New York, Leco Corporation, 1989.

[113] VOORT, G.F.V.; Metallography: Principles and Practice, New York, McGraw-Hill, 1984.

[114] AMERICAN SOCIETY FOR TESTING AND MATERIALS. ASTM E112-96 E2 (Reapproved 2004) - Standard test methods for determining average grain size. American Society for Testing and Materials. Philadelphia, 2004.

[115] ASTM E45- $05^{\mathrm{E} 3}$ - Standard test methods for determining the inclusions contents of steel. American Society for Testing and Materials. Philadelphia, 2005. 
[116] ASTM E-384-09 - Standard test method for microindentation

hardness of materials. American Society for Testing and Materials. Philadelphia, 2009.

[117] FERREIRA, M. G. S. et al. Semiconducting properties of oxide and passive films formed on AISI 304 stainless steel and alloy 600. Journal of Brazilian Chemical Society, v. 13, n. 4, p. 433-440, 2002.

[118] CARMEZIM, M. J. et al. Electrochemical behavior of thermally treated Croxide films deposited on stainless steel. Corrosion Science, v. 44, n. 3, p. 451-465, 2002.

[119] CARMEZIM, M. J. et al. Capacitance behavior of passive films on ferritic and austenitic stainless steel. Corrosion Science, v. 47, n. 3, pp. 581-591, 2005.

[120] ASSIS, S. L. Investigação da resistência à corrosão da liga Ti-13Nb-13Zr por meio de técnicas eletroquímicas e de análise de superfície. Tese (doutorado). Instituto de Pesquisas Energéticas e Nucleares, São Paulo, 2006.

[121] PAN, J., KARLEN, C., ULFVIN, C. Electrochemical study of resistance to localized corrosion of stainless steels for biomaterial applications. Journal of Electrochemical Society, v. 147, pp. 1021-1025, 2000.

[122] ANTUNES, R. A. Caracterização do comportamento frente à corrosão de um aço inoxidável austenítico para aplicações biomédicas com revestimentos 
PVD de TiN, TiCN e DLC. Tese (doutorado) - Instituto de Pesquisas Energéticas e Nucleares. São Paulo, 2006.

[123] CASTLE, J. E., CLAYTON, C. R. The use of X-ray photo-electron spectroscopy in the analyses of passive layers on stainless steel. Corrosion Science, v. 17, n. 1, pp. 7-26, 1977.

[124] GONZÁLEZ, J. E. G., MIRZA-ROSCA, J. C. Study of the corrosion behavior of titanium of its alloys for biomedical and dental implant applications. Journal of Electroanalytical Chemistry, v. 471, pp. 109-115, 1999.

[125] CUNHA BELO, M. et al. Composition, structure and properties of the oxide films formed on the stainless steel $316 \mathrm{~L}$ in a primary type pwr environment. Corrosion Science, vol. 40, n. 2/3, pp. 447-363, 1998.

[126] STALDER, M.; et al; Retransformation $\left(\alpha^{\prime} \rightarrow \gamma\right)$ kinetics of strain induced martensite in 304 stainless steel. Materials Science and Engineering A, v. 280, p. 270-281. 2000.

[127] DAVIS, J. R., ed. ASM International Handbook. Specialty Handbook: Stainless Steels. Materials Park, ASM International, 1994 p.10.

[128] XAVIOR, M.A.; ADITHAN, M.; Determining the influence of cutting fluids on the tool wear and surface roughness during turning of AISI 304 austenitic stainless steel. Journal of Materials Processing Technology, v. 209, p. 900-909, 2009. 
[129] KRUPP STAHL AG. Nichtrostende Stähle, Bochum, p.14.

[130] Jindal Stainless Steel. Catálogo disponível em:

http://www.jindalstainless.com/product broch.pdf. Acesso em 07.fevereiro.2010.

[131] Outokumpu. Catálogo disponível em:

http://www.outokumpu.com/pages/SubAreaPage42345.aspx. Acesso em 24.abril.2010. 
ANEXO A - Propriedades físicas e térmicas dos aços AISI 201 e AISI 304

\begin{tabular}{|c|c|c|c|c|}
\hline Parâmetros & Unidade & AISI 201 & AISI 304 & Referência \\
\hline Densidade & $\mathrm{g} / \mathrm{cm}^{3}$ & 7,8 & 8,0 & [127] \\
\hline Limite de resistência & $\mathrm{MPa}$ & 655 & 515 & [127] \\
\hline Limite de escoamento & $\mathrm{MPa}$ & 310 & 205 & [127] \\
\hline Alongamento & $(\%)$ & 40 & 40 & [127] \\
\hline Módulo de elasticidade & $\mathrm{MPa}$ & 197 & 193 & [127] \\
\hline Módulo de cisalhamento & $\mathrm{kN} / \mathrm{mm}^{2}$ & -- & 79 & [48] \\
\hline Coeficiente de Poisson & -- & 0,3 & 0,3 & [127] \\
\hline Resistividade elétrica & $\mu \Omega . \mathrm{cm}$ & 69 & 72 & {$[48,127]$} \\
\hline $\begin{array}{l}\text { Coeficiente de expansão térmica } \\
\text { médio de } 0 \text { a } 100{ }^{\circ} \mathrm{C}\end{array}$ & $\mu \mathrm{m} / \mathrm{m} .{ }^{\circ} \mathrm{C}$ & 15,7 & 17,2 & [127] \\
\hline $\begin{array}{l}\text { Coeficiente de expansão térmica } \\
\text { médio de } 0 \text { a } 315^{\circ} \mathrm{C}\end{array}$ & $\mu \mathrm{m} / \mathrm{m} .{ }^{\circ} \mathrm{C}$ & 17,5 & 17,8 & [127] \\
\hline $\begin{array}{l}\text { Coeficiente de expansão térmica } \\
\text { médio de } 0 \text { a } 538{ }^{\circ} \mathrm{C}\end{array}$ & $\mu \mathrm{m} / \mathrm{m} .{ }^{\circ} \mathrm{C}$ & 18,4 & 18,4 & [127] \\
\hline Condutividade térmica a $100{ }^{\circ} \mathrm{C}$ & $\mathrm{W} / \mathrm{m} \cdot \mathrm{K}$ & 16,2 & 16,2 & [127] \\
\hline Condutividade térmica a $500{ }^{\circ} \mathrm{C}$ & $\mathrm{W} / \mathrm{m} \cdot \mathrm{K}$ & 21,5 & 21,5 & [127] \\
\hline Capacidade calorífica específica & $\mathrm{J} / \mathrm{kg} \cdot \mathrm{K}$ & 500 & 500 & {$[48,127,128]$} \\
\hline Permeabilidade magnética & -- & 1,02 & 1,02 & {$[106,127]$} \\
\hline
\end{tabular}


ANEXO B - Correlação entre normas para os aços AISI 201 e AISI 304

\begin{tabular}{ccccc}
\hline País & $\begin{array}{c}\text { Abreviação } \\
\text { da norma }\end{array}$ & AISI 201 & AISI 304 & Referência \\
\hline EUA & AISI & 201 & 304 & {$[129]$} \\
França & UNS & S 20100 & S 30400 & {$[129]$} \\
Alemanha & Werkst. N. & 1.4372 & Z 6 CN 18-09 & {$[129]$} \\
Japão & DIN & X12CrMnNiN17-7-5 & X 5 CrNi 18 10 & {$[129]$} \\
Suécia & JIS & SUS 201 & SUS 304 & {$[129]$} \\
Rússia & SS & -- & 2332 / 2333 & {$[129]$} \\
Itália & UNI & -- & 08Ch18N10 & {$[129]$} \\
Reino Unido & BS & -- & X 5 CrNi 18 10 & {$[129]$} \\
Índia & IS & X10Cr17Mn6Ni4N20 & X04Cr19Ni9 & {$[130]$} \\
China & -- & 1 Cr17Mn6Ni5N & 0Cr18Ni9 & {$[131]$} \\
Coréia & KS & STS 201 & STS 304 & {$[131]$} \\
\hline
\end{tabular}

